\title{
O AGENTE COMUNITÁRIO DE SAÚDE DO PROJETO QUALIS:
}

\author{
AGENTE INSTITUCIONAL \\ OU \\ AGENTE DE COMUNIDADE?
}

JOANA AZEVEDO DA SILVA

Tese de Doutorado apresentada ao Departamento de Prática de Saúde Pública da Faculdade de Saúde Pública da Universidade de São Paulo para obtenção do Grau de Doutor

Área de Concentração: Administração Hospitalar

Orientadora: Profa Dra Ana Maria Malik

São Paulo 
" O Agente de saúde deveria ser treinado para lidar com problemas, como drogas, fome, violência..."

(agente comunitário de saúde do QUALIS, região Leste)

Por que você gosta de ser agente de saúde?

"Pela amizade com a população ter ampliado, pelo salário, pelo que aprendi..." (agente comunitário de saúde do QUALIS, região Norte)

Quando você não gosta de ser agente de saúde?

"Quando em uma escala, parece ser o menor de todos:dizem que o agente é a peça chave, mas nunca é reconhecido."

(agente comunitário de saúde do QUALIS, região Sudeste)

"Quando a gente apanha dos dois lados: nas casas e da equipe: cachorro que tem muito dono, morre de fome."

(agente comunitário de saúde do QUALIS, região Sudeste) 


\section{DEDICATÓRIA}

\section{A Eleutério Rodriguez Neto}

A Izabel dos Santos

pela instigante influência na minha formação profissional.

A meu pai, Hemetério, escravo, e à sua luta pela liberdade, pela inclusão e pela solidariedade entre os homens, influência primeira e decisiva na identidade do ser “eu”...

A minha mãe, Adalice, sempre o porto seguro...

A Tatiana, a Vladimir e a Pedro,

a Moisés, por todos os momentos.

A minhas irmãs, Idalina, Lia, Isabel, a esperança e a conformação de que éramos seis; a Natália e a Marina

Maria Cecília Ferro Donnangelo e

Ricardo Bruno Mendes Gonçalves:

não sei o que é mais forte neste Trabalho: se a presença de vocês ou a saudade pela falta que vocês fazem... 


\section{APRESENTAÇÃO}

O presente projeto volta-se ao estudo e à compreensão do Agente Comunitário de Saúde, referido como um elemento nuclear da realização de determinadas Políticas de Saúde, em especial de Programas que expressam modelos para reorientação da assistência à saúde no país. Atualmente, esse tipo de Programa encontra-se em fase de expansão, tanto em áreas rurais como em áreas urbanas. Além disso, esses modelos vêm sendo, cada vez mais, implantados em grandes cidades e áreas metropolitanas, mantendo, entre seus pressupostos e estratégias de intervenção básicos, as perspectivas de ampliação do acesso, de racionalidade técnica e econômica, de participação popular em saúde e de extensão de cobertura por serviços de saúde para parcelas específicas da população brasileira.

Historicamente, a idéia do Agente de Saúde envolve um conceito que, sob as mais diferentes formas e nomenclaturas, aparece em várias partes do mundo, ou seja, a idéia essencial de elo entre a comunidade e o sistema de saúde.

O presente trabalho tem, como referência inicial, a tese de que o agente comunitário de saúde que atua no Projeto QUALIS, especificamente no município de São Paulo, tem mais especificidades que analogias por referência a seus congêneres, em outras regiões e momentos históricos do Brasil. Trata, assim, de examinar a constituição de identidades ocupacionais ou profissionais no interior de um projeto de relação Estado - Sociedade, em especial em relação aos agentes comunitários de saúde, de caracterizar seu perfil em áreas metropolitanas, suas perspectivas e necessidades.

A premissa principal do trabalho é a determinação histórica e social das concepções e das práticas de saúde e, por conseqüência, do perfil dos seus sujeitos. Nessa perspectiva, assumindo-se que a identidade ocupacional é construída em uma determinada realidade, afirma-se que existem variações no perfil do agente de saúde, em termos dos aspectos centrais que orientam as possibilidades de viabilização das intervenções e da mediação Estado -Sociedade almejada por essas políticas.

Com esse entendimento, iniciou-se o desenvolvimento deste estudo pela recuperação das políticas e de suas expressões, os programas que, no Brasil, nos diferentes contextos, previam a participação do Agente de Saúde. O passo seguinte foi 
a identificação, nessas propostas, da concepção e de outros aspectos nucleares referentes ao agente de saúde que permitissem, com apoio do referencial teórico, identificar categorias, discutir conceitos e caracterizar o perfil e o papel destinado ao agente de saúde, como parte de uma Política de Saúde, nos diferentes momentos históricos e nos respectivos programas. Essa abordagem possibilitou a compreensão das principais idéias e conceitos subjacentes à proposição de agentes de saúde, em cada um dos momentos, em cada uma das propostas analisadas.

$\mathrm{Na}$ recuperação dessas propostas, optou-se por circunscrevê-las ao que está contido em documentos que registram estratégias oficiais - municipais, estaduais ou federais - que previam a participação do Agente de Saúde, não incluindo, na revisão e análise, as iniciativas que escapavam ao âmbito da intervenção direta do Estado.

A motivação para a escolha do objeto de estudo é decorrência de uma trajetória profissional e pessoal que permitiu a participação, em momentos cruciais da conjuntura sanitária brasileira, em diferentes estágios de realização de propostas de reorganização da atenção à saúde, que buscavam construir articulações mais adequadas entre as necessidades de saúde das populações e a oferta de serviços de saúde.

Como testemunha ocular da história de algumas dessas propostas, senti-me quase na obrigação de dar seqüência a um processo de ação-reflexão-ação em relação a esse objeto, processo advindo de uma trajetória que se iniciou quando da opção, na Escola de Enfermagem da Universidade Federal da Bahia pela habilitação em Saúde Pública, no $4^{\circ}$ ano do Curso. Ao final do Curso, nos idos de 1966, embora com trabalho já definido, em Salvador, a incursão pela Avenida Sete de Setembro, até a Diretoria Regional de Saúde da Fundação SESP, o aceite para trabalhar na Unidade Sanitária do município de Itabuna, região cacaueira, onde a responsabilidade por uma determinada área geográfica e pela população ali residente, a supervisão e o treinamento de visitadoras sanitárias no atendimento na unidade e em visitas domiciliares a gestantes, a crianças e a adultos, a supervisão e o treinamento de parteiras "curiosas", deram um sentido todo especial aos ensinamentos oriundos da habilitação acadêmica. Após 4 anos, a saída da F.SESP e a decisão de vir para São Paulo, a procura de emprego e a oportunidade de prestar concurso para a USP, para coordenar o serviço de enfermagem de um Centro de Saúde Escola, tendo em vista a viabilização da proposta do Curso Experimental de Medicina. 
Enquanto aguardava o concurso, a oportunidade de participar de projeto de investigação das condições de saúde da região do Vale do Rio Ribeira. Posteriormente, o trabalho no Centro de Saúde Escola do Butantã, o contato com o Departamento de Medicina Preventiva da USP, a equipe, o aprendizado, o trabalho, o carinho dos colegas...

Em dezembro de 1979, a saída do C.S. E. Butantã e o ingresso, no Ministério da Saúde - Delegacia Federal de Saúde de São Paulo, onde, a responsabilidade pelo acompanhamento dos programas do Ministério em São Paulo, e a expansão do Programa de Interiorização das Ações de Saúde e Saneamento - PIASS - para áreas carentes da região sudeste, possibilitaram a minha volta ao Vale do Ribeira e a continuidade de uma trajetória e de uma linha de trabalho. Assim, a assinatura do Convênio entre a Secretaria de Estado da Saúde, o Ministério da Saúde e o INAMPS, possibilitou a implantação do PIASS em 16 localidades rurais de 8 municípios da região do Vale do Rio Ribeira. Em 1981, a participação nas reuniões com a população, à noite e em finais de semana, para definir a localização dos postos de saúde, para seleção dos agentes, o treinamento (todo gravado), a organização da referência, o início do trabalho dos agentes.

Em 1983, quase 2 anos depois da implantação dos Postos Rurais, em conjunto com a Profa. Maria Cecília Ferro Donnangelo, iniciei o desenvolvimento de um projeto de avaliação do Programa, dando ênfase ao trabalho dos agentes de saúde. Essa pesquisa, viabilizada mediante financiamento da Secretaria de Ciência e Tecnologia do Ministério da Saúde e articulação com a Universidade Estadual de Campinas, foi possível graças ao apoio de vários companheiros; alguns deles estão comigo neste trabalho, outros fazem acontecer outros projetos e outros ainda, não mais estão conosco. A minha dissertação de mestrado, apresentada em 1994, foi o produto daquele esforço solidário.

Em 1985, mudei-me para Brasília, de onde, com a equipe da Coordenação Geral de Desenvolvimento de Recursos Humanos para o SUS, pude acompanhar o início do Programa de Agentes de Saúde do Ceará e, posteriormente, o nascimento, as negociações para a consolidação do Programa Nacional de Agentes Comunitários de Saúde do Ministério da Saúde e o nascimento do Programa de Saúde da Família.

Voltando para São Paulo, acompanhei e relatei, como "Escriba" da Secretaria de Saúde do Estado, no final 1995, os primeiros passos do QUALIS - Convênio entre 
a Secretaria de Estado da Saúde, o Ministério da Saúde e a Casa de Saúde Santa Marcelina - modelo de PSF implantado, pelo Estado, na zona leste do município de São Paulo e, posteriormente, a partir de final de 1997, a ampliação, através de parceria com a Fundação Zerbini, para as regiões norte e sudeste. Daí para, a partir de 1999, participar, com outros pesquisadores, de um Projeto de Avaliação do QUALIS, foi apenas questão de tempo e de oportunidade.

Assim, cabe ressaltar a inserção deste Trabalho de tese em um projeto maior de pesquisa: Novos Modelos de Assistência à Saúde: Avaliação do Programa de Saúde da Família no Município de São Paulo, que vem sendo desenvolvido por pesquisadores do Departamento de Medicina Preventiva da Faculdade de Medicina da USP, dos Departamentos de Epidemiologia e de Prática de Saúde Pública da Faculdade de Saúde Pública da USP, da Escola de Administração de Empresas da Fundação Getúlio Vargas, do Departamento de Medicina Social da Faculdade de Ciências Médicas da Santa Casa de São Paulo, e da Secretaria de Estado da Saúde, financiado, em uma primeira etapa, pela Fundação Zerbini e, na continuidade, pela FAPESP. A coordenação geral do Projeto é do Professor Adib Domingos Jatene, batalhador incansável pela viabilização dessa proposta e pela realização dessa pesquisa.

Durante todo o desenvolvimento do trabalho, a minha preocupação foi manter o equilíbrio na exposição dos fatos e nas considerações teóricas. Não tenho nenhuma certeza de havê-lo conseguido. Procurei, entretanto, evitar que meus sentimentos pessoais, que minha opiniões preponderassem sobre o interesse pelo conhecimento que estava sendo evidenciado.

Essa foi uma preocupação constante, a de garantir, mediante metodologia adequada e sucessivas aproximações, a produção de um conhecimento mais compreensivo, ou seja, que pudesse dar conta do conjunto das dimensões interrelacionadas do objeto estudado.

Fazer um estudo, como o que aqui se apresenta, sobre um Programa ou sobre determinado aspecto de realização desse Programa, não implica concluir que ele seja um sucesso inquestionável, nem apontá-lo como ineficaz ou pouco eficiente em relação a outros já existentes. Trata-se de tomar um objeto e analisá-lo, segundo critérios previamente estabelecidos e conhecidos (MALIK e SCHIESARI 1998), identificando como foram definidos os critérios. 
Um conjunto de abordagens complementares foi usado no sentido de aumentar a abrangência e a profundidade do "olhar", para propiciar essa compreensão articulada, construída, a partir de diferentes ângulos, de uma determinada realidade. Assim, em nenhum momento, o objetivo foi identificar o certo, o errado, o bom, o ruim, o bem ou o mal, mas compreender a realidade.

Daí, que os resultados obtidos não me permitem afirmar, por um lado, que tais características encontradas, tal padrão de desempenho é o prevalente ou em todas as unidades e equipes do QUALIS ou de Programas de Saúde da Família, em áreas metropolitanas. Por outro lado, o processo desenvolvido, a metodologia utilizada permitem-me afirmar que esse é um padrão encontrado e encontrável em circunstâncias similares às estudadas, mas que é um padrão também possível de ocorrer em condições outras, um pouco diversas, assemelhadas, condições próximas e não, necessariamente, apenas, sob as mesmas condições.

Nessa linha, uma outra consideração diz respeito à natureza deste trabalho e à expectativa em relação ao produto que dele se origina. É uma tese e, como tal, um trabalho acadêmico, inserido em certas normas e com muitos limites em relação ao aproveitamento pela prática gerencial. Assim, por um lado, não é um trabalho diretamente utilizável pela prática gerencial, embora tenha tomado preocupações gerenciais também como objeto. Por outro lado, embora não haja um compromisso direto com a gerência de sistemas e serviços de saúde, vários aspectos do conhecimento produzido poderão ser utilizados em orientação à tomada de decisão na implantação de Programas de Saúde da Família e no trato com dimensões relativas ao Agente Comunitário de Saúde, seja em áreas metropolitanas, seja em outros contextos.

Nessa perspectiva, utilizando os estudos de NOVAES (2000), esta tese apresenta tanto características de uma investigação avaliatória (com o objetivo de produzir conhecimento, através de avaliador externo, com utilização de informação para demonstração, com comprovação/negação de hipóteses e temporalidade pontual) quanto características de uma avaliação para decisão, no sentido de que o enfoque priorizado é a caracterização/compreensão de um contexto, a metodologia dominante é qualitativa e situacional, o contexto de avaliação é natural, e as informações obtidas também pretendem ser utilizadas como instrumento para gestão. Por outro lado, ele servirá, também, como apoio para tomada de decisões (o que caracteriza a avaliação para gestão). 
Uma investigação como esta, embora implique alguns momentos de reflexão solitária, não é um trabalho solitário. Este é um produto possível graças à participação de inúmeros sujeitos, alguns presentes e citados e outros nem referidos. Uma contribuição de todos com que pude dialogar e aprender, em determinados momentos e em todos os momentos de uma trajetória profissional. Assim, é um trabalho coletivo e solidário.

Vários foram os tipos e os momentos de apoio; nenhum menos importante, todos indispensáveis. Mesmo sabendo da impossibilidade de lembrar de todas as pessoas que contribuíram para os resultados aqui apresentados, e sob o risco de esquecer companheiros importantes, registro algumas participações.

Os profissionais das equipes de saúde da família, os diretores das unidades que, com o seu entusiasmo, possibilitaram a realização deste trabalho, tornando a coleta de dados uma tarefa tanto agradável quanto esclarecedora. Muitas dessas pessoas demonstraram um vivo e estimulante interesse pela pesquisa e pelos seus resultados, os quais espero que sejam explorados, ao máximo, em suas possibilidades, no sentido de ajudar nos desafios encontrados, no dia-a-dia.

As famílias que, visitadas pelos agentes de saúde, ao concordar que o observador entrasse em suas casas, contribuíram para que as observações do trabalho pudessem cumprir os objetivos. O mesmo reconhecimento para com as pessoas integrantes de movimentos da comunidade, que, quando solicitado, prontificaram-se a ser entrevistadas.

A Secretaria de Estado da Saúde, o Professor José da Silva Guedes e José Ademar, pelo incentivo para prosseguir, o Professor José Carlos Seixas, pelas oportunas e didáticas reflexões.

O Professor Adib Jatene, pelo estímulo e permanente interesse durante todo o desenvolver da pesquisa.

A Fundação Zerbini, que financiou a primeira fase de desenvolvimento dos trabalhos de campo. Dr. Paolo Bellotti, pelo entendimento da importância da investigação e pelo apoio para que ela se viabilizasse. A Casa de Saúde Santa Marcelina, pelo interesse.

A Milton Pacífico por entender as necessidades dos momentos de redação final de uma tese. Aos companheiros e colegas do QUALIS Zerbini, pelo apoio e incentivo. 
Agradeço aos coordenadores técnicos dos QUALIS, David Capistrano Filho e Rosa Maria de Barros, aos coordenadores de áreas técnicas específicas e aos coordenadores regionais do QUALIS da Fundação Zerbini.

A Nelson Rodrigues dos Santos, os argumentos para que eu retomasse, no doutorado o objeto de estudo do mestrado

A Sábado Girardi e a Roberto Passos Nogueira, as oportunas sugestões, na hora mais decisiva.

Às colegas Danusa, Arendelita, Heloíza, Fátima, Karina, a atenção que dispensaram a essa investigação.

Aos sujeitos com os quais tive o privilégio de conviver nessa trajetória de vida, na Fundação SESP, no Departamento de Medicina Preventiva da Faculdade de Medicina da USP, no Centro de Saúde Escola do Butantan, no Projeto Devale, na Delegacia Federal de Saúde, no Ministério da Saúde, na Coordenação Geral de Desenvolvimento de Recursos Humanos para o SUS, na Secretaria Municipal de Saúde de Campinas, na Secretaria de Estado da Saúde de São Paulo.

Tenho uma grande dívida para com Maria Novaes, cúmplice, desde o primeiro momento. Conversar com ela ajudou-me a construir argumentos, a aperfeiçoar o texto.

A Lília Blima Schreiber, cuja solidariedade, desde o mestrado, aliada à disponibilidade e a riqueza da argumentação, foram muito importantes.

A Regina Marsiglia, pela riqueza técnica do apoio, sempre "temperados" com otimismo e solidariedade.

A Amélia Cohn, a atenção imediata para ajuda na definição do objeto de estudo.

Aos entrevistadores, observadores, transcritores de fita, que não se limitaram a desempenhar uma tarefa mas participaram, vivenciaram, aprenderam e contribuíram.

À FAPESP, pelo apoio.

A Augusta Sato, a Marina Peduzzi, a Vilma Venâncio, a Ana Chiesa, em nome de todas as colegas que me ajudaram e incentivaram.

A Ana Sílvia Whitaker Dalmaso, a Jurema Palomo, a competência, o carinho e a solidariedade ímpares.

A Zuleika, a sempre presente, calma e eficiente amiga.

A Marina e à menina Manuela que a tudo assistiu, protegida, na sua redoma natural. 
A Lia, minha irmã que, na concepção do referencial teórico, contribuiu com o que pôde e com o que não podia.

A Danilo Noritomi, pela solidariedade nos momentos finais.

A Stela, pelos 20 anos de convivência fraterna.

A Roberto Santana, sua competência na apresentação gráfica deste trabalho.

A todos os que contribuíram direta ou indiretamente para este estudo.

A Ana Maria Malik, que soube, com propriedade, acompanhar, durante quatro anos, uma geminiana, garantindo, a um só tempo, uma orientação firme e eficiente e a liberdade de criar, de propor, de sonhar...

Aos Agentes Comunitários de Saúde do QUALIS Zerbini e do QUALIS Santa Marcelina... esperando ter feito bom uso do esforço de vocês e contribuir para a construção da identidade e da cidadania, com este trabalho singular, até porque é plural. 


\section{RESUMO}

O presente estudo tem como objetivo a caracterização do Agente Comunitário de Saúde que atua no Projeto QUALIS, denominação assumida, em São Paulo, pelo Programa de Saúde da Família, tomando-o como elemento nuclear para a realização de dimensões específicas de políticas e programas de saúde de caráter público e que tiveram a sua maior expressão no Brasil, a partir da $2^{\text {a }}$ metade da década de 70 . Através de dados obtidos com abordagens diversas - documentos, observação do trabalho, entrevistas, buscou-se compreender o perfil desse agente, inserido em uma região metropolitana, em sua tentativa de viabilizar o acesso da população aos serviços e sistemas de saúde, atuando através de dois tipos de práticas na realização das políticas propostas: um de natureza predominantemente técnica, de organização do acesso aos serviços e às ações de promoção, proteção e recuperação da saúde; e outro de natureza predominantemente política, expressa no estímulo à participação e organização popular para a conquista de diretos de cidadania. Para a caracterização do perfil, foram montadas categorias de análise, correspondentes aos dois pólos de atuação: agente institucional ou agente de comunidade.

Os resultados apontam para o fato de que essas duas categorias representam situações polares, que não existem em sua forma "pura". A aproximação do perfil ocupacional-social do agente de uma ou de outra das categorias de análise é resultado de interações mediadas pela influência de múltiplas variáveis, levando a uma variabilidade no seu perfil, na dependência de contextos específicos e das situações concretas de trabalho. Esse processo, sempre mediado por conflitos na prática cotidiana, orienta os padrões operativos do agente, às vezes de maior aderência à instituição, às vezes de solidariedade à comunidade, face às especificidades do contexto em que ocorre. Essa situação tem profundas influências e demandas para a organização do trabalho, inclusive na disponibilidade de tecnologia e de saberes para a prática dos agentes, nessas propostas.

Nas conclusões do trabalho são discutidos os desafios colocados para esse trabalhador tendo em vista o cumprimento da sua função nesses programas e das expectativas institucionais e sociais, relativas à sua atuação em regiões metropolitanas. 


\section{SUMMARY}

The study's objective was the characterization of the Community Health Agent in the QUALIS Project, the name given in São Paulo to the Family Health Program, while considering him as a nuclear element for the achievement of specific dimensions of public health policies and programs in evidence in Brazil since the second half of the seventies.

Using the information obtained with different approaches - documents, observation, interviews - a comprehension of the agents' profile was sought, in his condition of working in a metropolitan area, trying to enhance the populations' access to health services, and using two types of practices: one of a predominantly technical nature, of organization of the utilization of services and promotion, prevention and recuperation activities, and the other of a predominantly political nature, expressing itself through the stimulation of the participation and level of organization of the population to obtain their citizen's rights. To characterize the agents profile, analytical categories were developed, with the identification of two polar types of identity: institutional agent or community agent.

The results show that these categories represent in fact extreme situations which do not exist in "pure" form. The movement towards one or the other analytical category is the result of interactions between multiple intervening variables, which leads to a considerable variability in their concrete identity, depending on the context and specific situations which they face in daily work. This process, always leading to conflicting situations, orients the operational patterns adopted by the agent, leading to greater institutional solidarity or to the community to which they are supposed to belong. This situation deeply influences and creates continuous demands on the organization of the work, and on the recognition of the technologies and practices needed by the agents, in these programs.

In conclusion, the challenges the agent has to face in the program are discussed, and the existing institutional and social expectations for its performance in metropolitan areas. 


\section{ÍNDICE}

APRESENTAÇÃO

1. INTRODUÇÃO - Referências para Análise

1.1 Dos Programas de Extensão de Cobertura aos

Programas de Saúde da Família 1

1.2 Referências Teóricas 72

1.3 A Investigação 107

2 OBJETIVOS 112

3. MÉTODOLOGIA 114

4. RESULTADOS 134

4.1 O Agente Comunitário de Saúde do QUALIS 134

$\begin{array}{lll}\text { 4.1.1 Caracterização } & 134\end{array}$

4.1.2 A Prática dos Agentes Comunitários de Saúde do QUALIS 139

4.2 Caracterização do perfil ocupacional - social do

Agente Comunitário de Saúde do QUALIS 162

4.3 O Agente Comunitário de Saúde pelos demais sujeitos do QUALIS 168

4.3.1 Nível Central - formuladores e gestores 168

4.3.2 Nível Local - gerente, demais profissionais da equipe, membros de organizações comunitárias e do $\begin{array}{ll}\text { Conselho de Saúde } & 168\end{array}$

5. DISCUSSÃO 185

5.1 A identidade dos Agentes de Saúde do QUALIS 185

5.2 Os Agentes do Saúde do QUALIS e os Agentes de propostas anteriores: analogias e especificidades 192

6. CONCLUSÕES 206

7. REFERÊNCIAS 211 


\section{INTRODUÇÃO}

\section{REFERÊNCIAS PARA ANÁLISE}

\subsection{DOS PROGRAMAS DE EXTENSÃO DE COBERTURA AOS PROGRAMAS DE SAÚDE DA FAMÍLIA}

As últimas décadas têm sido marcadas por repetidas tentativas de organização da assistência à saúde em moldes capazes de conciliar diferentes ordens de determinações que incidem sobre o setor e nele introduzem elementos conflitantes de difícil superação. Destacam-se, entre eles, os que dizem respeito às inovações científicas e tecnológicas experimentadas pela prática médica, com todos os seus corolários - consubstanciados sobretudo na questão dos custos crescentes da atenção médica. Dentre essas tendências, ressaltam-se, para este trabalho, aquelas que refletem as exigências histórico-estruturais da extensão da assistência a parcelas crescentes da população.

"Sob o impacto, tanto da nova tecnologia material que, além de modificar inteiramente a prática médica, a articula de maneira peculiar com toda a estrutura de produção de bens materiais, quanto das exigências econômicas e políticas de extensão do consumo de serviços de saúde a categorias sociais até então marginalizadas de tal consumo, a atenção médica passa por marcadas modificações" (DONNANGELO 1979).

DONNANGELO, em 1979, apontava para a influência dos movimentos de Medicina Integral, Medicina Preventiva e, em especial, do da Medicina Comunitária nas origens dos programas de extensão de cobertura e na utilização de pessoal auxiliar. "Reafirmando os princípios básicos elaborados através de outros projetos, já referidos, de organização da atenção médica, a Medicina Comunitária se propõe operacioná-los através de uma específica estratégia de prestação de serviços à população. Grande parte do campo de ação comunitária em saúde pode ser caracterizado pela busca de extensão da assistência médica a parcelas crescentes da população através do desenvolvimento das atividades de saúde usualmente designadas como de primeira linha (grifo nosso). Sua especificidade, entretanto, decorre do fato de que essa extensão da assistência não se fará necessariamente através das modalidades de prestação de serviços e da tecnologia médica predominante mas, sobretudo, por meio 
de uma nova estruturação dos elementos que compõem a assistência à saúde, em particular um novo uso do trabalho nesse campo (grifo da autora). Reforça-se substancialmente no interior do projeto comunitário um elemento que, embora não seja estranho à prática médica contemporânea, não adquiriu relevância a não ser em raros modelos de organização da assistência. Trata-se do uso do trabalho não médico na área da saúde, articulando-se ao trabalho médico e resultando no que poderia ser designado por trabalhador médico coletivo, atuando de forma tal que, por um processo de distribuição de tarefas, a assistência se efetua através de um conjunto de práticas complementares".

Em setembro de 1978, em Alma-Ata, República do Casaquistão, URSS, realizou-se a Conferência Internacional de Cuidados Primários em Saúde, organizada pela Organização Mundial de Saúde e pelo Fundo das Nações Unidas para a Infância. Esse Evento teve grande repercussão para a implantação, em inúmeros países, de programas de Cuidados Primários de Saúde para populações específicas.

O Relatório Final de Alma-Ata afirmava que para o alcance, por todas as populações do mundo, de um nível aceitável de saúde, num futuro previsível, os cuidados primários de saúde seriam os principais meios. Nesse sentido, o nível de saúde de uma população precisaria estar integrado ao desenvolvimento social e baseado no espírito de justiça.

Os Programas de Saúde da Família, propostos e implantados tanto em países desenvolvidos quanto naqueles em desenvolvimento, procuram responder ou se articulam a questões específicas de cada contexto e se sustentam em justificativas que se orientam principalmente por racionalidades econômicas, científicas e técnicas, associadas a perspectivas "humanistas", isto é, do bem estar físico, mental e social, como meta para o homem.

Correspondem a uma linhagem de propostas com características semelhantes que vêm sendo preconizadas, principalmente, a partir da Segunda Guerra Mundial, por organismos ou instituições de natureza pública, nacionais ou internacionais, como modelos para a reorganização da assistência à saúde (Medicina ou Saúde Comunitária, Medicina ou Atenção Integral à Saúde, Atenção Primária em Saúde, entre outras).

Historicamente, a exemplo de outros setores sociais, no Brasil, a saúde não ocupou senão uma posição secundária nas definições de política econômico-social do Estado, bem como no processo de planejamento que abordou, mais intensamente, os 
setores econômicos. Os sucessivos planos de desenvolvimento propostos para a sociedade brasileira caracterizaram-se sempre por uma marcada subordinação das medidas na área social aos objetivos específicos da política econômica (DONNANGELO 1979).

No Brasil, concentram-se mais precisamente nas três últimas décadas, as tentativas de reorganização da assistência à saúde, com esse específico objetivo.

Um marcante contraste caracterizava, no começo dos anos 70, o cenário da assistência médica brasileira: de um lado, a dominância de uma medicina altamente diferenciada, de elevado custo e intenso consumo por parte de determinado estrato da população; de outro, a presença de grandes contingentes populacionais desprovidos de assistência médica, e de necessidades básicas de saúde que não encontravam condições institucionais adequadas para o seu atendimento.

A remota possibilidade de universalização, na sociedade brasileira, daquele padrão assistencial diferenciado, impunha, por conseqüência, a necessidade do recurso a medidas tendentes a corrigir as distorções do modelo. Parecia óbvia a inviabilidade de medidas que alterassem radicalmente as bases da organização assistencial, daí a busca necessária de formas alternativas de racionalização do conjunto do setor compatíveis com o modelo dominante e capazes, ao mesmo tempo, de tornar o setor menos excludente frente às necessidades de saúde que buscam expressar-se através dele (DONNANGELO 1979).

Concentrando-se, naturalmente, nas definições da política econômica, o II Plano Nacional de Desenvolvimento (1975-1979) - II PND - caracterizava-se, entretanto, pela atribuição de uma relativa autonomia aos setores da área social, cuidando de abordá-los em termos de sua especificidade. Em termos textuais: " $a$ verdade é que, de um lado, o crescimento pode não resolver o problema da adequada distribuição de renda, se deixado à simples evolução dos fatores do mercado. E, de outro lado, a solução através do crescimento, apenas pode demorar muito mais do que a consciência social admite, em termos de melhorar rapidamente o nível de bem-estar de amplas camadas da população” (II PND 1975).

Correlatamente, o Plano formulava metas próprias para a política social, cuja implicação mais ampla dizia respeito à superação da marginalidade social e cultural e, naturalmente, econômica. $\mathrm{O}$ aumento da renda real para todas as categorias sociais e a "redução da pobreza absoluta, ou seja, do contingente de famílias com nível de renda abaixo do mínimo admissivel quanto à alimentação, saúde, habitação”, deviam 
ser possibilitadas através de uma ação em que se conjugassem medidas mais imediatamente econômicas, como a política de emprego e de salários, com uma estratégia adequada de prestação de serviços sociais (II PND 1975).

Por outro lado, também no referente ao Sistema de Previdência Social, "o decorrer da década de 70 assiste a outras propostas universalizantes que formalmente progrediram no sentido da formulação de um sistema de seguridade social". ... "São exemplos de extensão de cobertura: a instituição da cobertura previdenciária para os maiores de 70 anos e inválidos que tenham, em algum periodo, contribuído para a Previdência Social ou exercido qualquer atividade a ela vinculada, mesmo sem terem contribuído; a concessão de beneficios aos trabalhadores rurais acidentados no trabalho; a inclusão do salário-maternidade, até então sob responsabilidade da empresa; a extensão dos benefícios previdenciários às empregadas domésticas e trabalhadores autônomos, desde que contribuintes do sistema (COHN e ELIAS 1996).

Seguiram-se ao II PND uma série de diplomas legais na área social, entre os quais, a Lei do Sistema Nacional de Saúde, a primeira definição sistemática , embora limitada, de uma política de saúde para o país.

A Lei no. 6.229, de 17 de julho de 1975, dispôs sobre a Organização do Sistema Nacional de Saúde. Ocupou-se, basicamente, da designação e da ordenação dos setores institucionais sob cuja responsabilidade deveriam desenvolver-se as ações pertinentes à saúde: Conselho de Desenvolvimento Social, Ministério da Saúde, Ministério da Previdência e Assistência Social, Ministério do Interior, Ministério da Educação e Cultura, Ministério do Trabalho. Explicitava as respectivas competências desses setores, dos Estados e Municípios no desenvolvimento das ações, bem como os mecanismos através dos quais se processaria a coordenação, cabendo ao Conselho de Desenvolvimento Social, recentemente criado, assegurar as diretrizes de coordenação geral do Sistema (DONNANGELO 1979).

Seguiram-se, também, a elaboração e implantação de alguns programas sociais, entre os quais destacam-se, por sua relação com a questão sanitária, o Programa Nacional de Alimentação e Nutrição - PRONAN e o Programa de Interiorização de Ações de Saúde e Saneamento - PIASS (CORDONI 1979; ROSAS, 1981).

A essa época, os Programas de Extensão de Cobertura - PEC - já eram divulgados e defendidos por organismos internacionais e incluídos em documentos, tais como, o II Plano Decenal de Saúde para as Américas (1971-1980), resultante da III 
Reunião Especial de Ministros de Saúde da América Latina. Também a proposta dos PEC já aparecia nas Conclusões e Recomendações da V Conferência Nacional de Saúde, realizada sob o patrocínio do Ministério da Saúde, em Brasília, em 1975. (CORDONI 1979; ROSAS 1981; Brasil 1975).

A apresentação que se fará, a seguir, das Políticas de Saúde e de suas expressões em Programa nacionais ou locais, em ordem de momentos históricos, tem o objetivo de recuperar aspectos considerados nucleares da proposição e da implantação que tenham a ver com a identidade, expectativa de ações e de impacto do trabalho do Agente de Saúde, material central a ser resgatado no capítulo de Discussão de Resultados tendo em vista a caracterização do perfil do agente comunitário de saúde do QUALIS e a identificação de similaridades ou diferenças em relação a outras propostas que contemplem ou contemplaram esse sujeito como nuclear para sua viabilização.

Cabe ressaltar as limitações a que está exposta essa iniciativa na medida da utilização, para esse resgate, de diferentes fontes, as quais foram motivadas em sua descrição por razões e metodologias de natureza, certamente, diversas.

Procurar-se-á caracterizar essas propostas, no que houver de informações em termos de contexto histórico em que emergiram, justificativa, objetivos, população a que se destinavam, inserção do Agente e expectativa de impacto de suas ações, mecanismos de seleção, treinamento e supervisão, ações propostas para o agente, interação do agente com a estrutura organizacional, espaço de atuação, autonomia de decisão, interação com os outros profissionais, interação com os indivíduos, famílias e comunidade, relacionamento com a estrutura profissional vigente, concepção sobre sua identidade de agente e concepção sobre a importância do seu trabalho para a população, aspectos que, considera-se, possibilitarão a apreensão das dimensões objetivadas neste trabalho.

A retomada dessas propostas, de suas idéias centrais, não pode ser feita sem que se faça referência a um serviço que foi pioneiro no Brasil no que se relaciona com as idéias e concepções que integram os princípios e diretrizes dos programas aqui analisados: O Serviço Especial de Saúde Pública - SESP (1942-1960) e a Fundação Serviço Especial de Saúde Pública - F.SESP (1960-1990).

Em 17 de julho de 1942, foi assinado, pelo Dr. Osvaldo Aranha, Ministro de Estado dos Negócios das Relações Exteriores, pelo Brasil, pelo Dr. Jefferson Caffery, Embaixador Extraordinário e Plenipotenciário, no Rio de Janeiro, pelo Governo dos 
Estados Unidos da América e pelo Major Dr. George Mundock Saunders, como representante do IAIA, um contrato de cooperação que fazia nascer o Serviço Especial de Saúde Pública, mais conhecido como o SESP.

O Contrato instituía uma unidade administrativa mantida pela IAIA e subordinada diretamente ao Ministério da Educação e Saúde, incluindo entre suas atribuições:

- "o saneamento do Vale do Amazonas, especialmente a profilaxia e os estudos de malária no Vale e a assistência médico-sanitária aos trabalhadores ligados ao desenvolvimento econômico dessa região;

- o preparo de profissionais para trabalho de saúde pública, compreendendo o aperfeiçoamento de médicos e engenheiros sanitaristas, a formação de enfermeiras de saúde pública e o treinamento de outros técnicos;

- a colaboração com o Serviço Nacional de Lepra e por intermédio deste, com as repartições sanitárias estaduais, para o combate à Lepra” (BASTOS 1996).

Inicialmente os programas desenvolvidos pelo SESP incluíam, apenas, o Programa da Amazônia e o Programa da Migração. A assistência médica aos trabalhadores removidos do Nordeste para o Vale do Amazonas, para extração da borracha, foi uma das primeiras atividades.

Nos primeiros anos de existência, todas as atividades do SESP foram dirigidas, prioritariamente, no sentido de prestar assistência médico-sanitária às populações das áreas onde existiam matérias-primas de interesse estratégico para os países aliados, na guerra contra a Alemanha. Receberam, assim, essa assistência, os trabalhadores removidos do Nordeste para a exploração da borracha na região amazônica, bem como as populações já existentes na área e os trabalhadores empregados na extração da mica e cristal de rocha nos estados do Espírito Santo, Minas Gerais e Goiás e os utilizados na reconstrução da Estrada de Ferro Vitória-Minas, da Companhia do Vale do Rio Doce. Constituía ainda ponto importante do programa médico-sanitário nas regiões o combate à malária. Eram as seguintes, em síntese, as atividades desenvolvidas: 
- atividades de Saúde Pública: controle de doenças transmissíveis, estatística vital, enfermagem de saúde pública, educação sanitária, higiene pré-natal e da criança (higiene infantil, higiene pré-escolar, higiene escolar), saneamento do meio ambiente (água, dejetos, construção de fossas, higiene da habitação, combate à malária, fiscalização de gêneros alimentícios);

- atividades de Assistência Médica: ao Adulto, à Mulher, à Criança;

- laboratório: exames de urina, sangue, fezes, escarro, muco nasal.

De início, as atividades do SESP foram dirigidas sob a influência, quase exclusiva, da medicina preventiva, dentro dos moldes clássicos norte-americanos. Logo, a Direção do SESP entendeu que era preciso oferecer, também, às populações, cuidados de assistência médica de que elas necessitavam, mesmo porque esses serviços, além de constituir um benefício, tornavam-se também um atrativo imediato, contribuindo para que as populações aceitassem, de bom grado, as medidas preventivas.

A propósito, BASTOS (1996) cita relatório da Conferência da Organização Sanitária, realizada em abril de 1948, da qual participaram técnicos do SESP, do Ministério da Saúde e da Faculdade de Higiene e Saúde Pública da Universidade de São Paulo.

Entre as conclusões dessa Conferência, que ressaltou a enorme importância do saneamento do meio ambiente, da educação para a saúde, da higiene materna, da higiene da criança, do combate às grandes endemias regionais e da prática de medidas de controle que pudessem ser utilizadas em massa e ao redor dos casos, destaca-se o que ficou estabelecido em relação à assistência médica:

"Considerando que, nas áreas em apreço, as condições de pauperismo das populações e a inexistência ou a insuficiência do número de médicos clínicos e leitos em hospitais forçaram o Programa da Amazônia a instituir serviços de assistência médica, e o do Rio Doce a condescender em prestar esses mesmos serviços no intuito de promover a recuperação, tão rápida quanto possível, da grande massa de doentes ainda existente, a Conferência da Organização Sanitária, reconhece:

a- que se torna necessário, nas áreas de trabalho do SESP, incluir assistência médica entre as funções de saúde pública. 
b- que a assistência médica, por outro lado, representa um atrativo imediato para a população que, recebendo esse beneficio de melhor maneira se prestará a aceitar as medidas de medicina preventiva.

c- que não será possível prescindir da existência de leitos em hospitais" (BASTOS 1996).

Nos anos que se seguiram, vários foram os atos de prorrogação do Contrato que deu origem ao SESP, até que, em 1960, foi criada a Fundação Serviço Especial de Saúde Púbica - F.SESP (1960-1990), vinculada ao Ministério da Saúde.

A F.SESP, dava continuidade a uma obra iniciada em 1942, pelo SESP. A Lei $\mathrm{n}^{\mathrm{o}} 3.750$ definiu os seguintes objetivos básicos da Fundação:

a- "organizar e operar serviços de saúde pública e assistência médico-hospitalar na áreas do território nacional onde se desenvolvem ou venham a se desenvolver programa de valorização, sempre que tais serviços não constem de órgãos federais específicos;

b- estudar, projetar e executar empreendimentos relativos à construção, ampliação ou melhoria de serviços de abastecimento de água e sistemas de esgotos, sempre que não constem de órgãos federais específicos;

c- desenvolver um programa de educação sanitária nas localidades onde mantiver unidades sanitárias;

$d$ - analisar, do ponto de vista técnico, e opinar sobre projetos e orçamentos relativos a serviços de abastecimento de água a serem construídos com financiamento do Banco Nacional de Desenvolvimento ou Caixas Econômicas Federais, nos termos da legislação em vigor;

e- coordenar, organizar e administrar, nos Estados cujos governos o solicitarem, serviços destinados ao desenvolvimento de sua estrutura sanitária básica, inclusive ao que se refere à promoção e controle da higiene industrial;

$f$ - coordenar, organizar e administrar, mediante regime de acordo com as municipalidades interessadas, serviços de abastecimento de água e esgotos;

g- colaborar com os órgãos técnicos do Ministério da Saúde na resolução de problemas de sua competência;

h- realizar pesquisas, inquéritos e estudos necessários ao desenvolvimento de suas atividades; 
i- promover a difusão de conhecimentos técnicos ligados à saúde pública, através de edição de livros, revistas e outras publicações;

j- promover a formação e o treinamento de pessoal técnico e auxiliar necessário à execução de suas atividades;

k- desenvolver programas em cooperação com os Estados, o Distrito Federal, os Territórios ou os Municípios, visando a higienização dos bairros pobres e a solução de problemas de saúde pública”( BASTOS 1996).

$\mathrm{O}$ resgate a que aqui se procede sobre a F.SESP baseia-se no entendimento de que essa instituição teve uma grande importância na concepção de diretrizes que, hoje, orientam as práticas de trabalho na proposição dos Programas de Agentes Comunitários de Saúde (PACS) e do Programa de Saúde da Família (PSF).

análise documental embasa a tese de que a F.SESP foi um "laboratório", foi pioneira na criação de modelos para as propostas de ampliação de cobertura para populações específicas, de práticas, de diretrizes e princípios que, hoje, se colocam, no PACS e no PSF, o que permitiu que se construísse experiência, que se avançasse no conhecimento. Entre esses aspectos, destacam-se:

- a oferta organizada de serviços na unidade, no domicílio e na comunidade: a puericultura, o pré-natal;

- o planejamento e a programação; a avaliação realizada em nível central

- a informação como base para a responsabilização sobre a população da área de abrangência;

- a abordagem integral da família;

- a unidade de saúde dinâmica, não estática; a unidade de saúde vai à população e vice-versa;

- a adscrição de clientela;

- a utilização de pessoal auxiliar para ampliar a cobertura para populações específicas;

- o trabalho com a comunidade;

- o monitoramento do trabalho e o treinamento de parteiras leigas, as "curiosas";

- a incorporação das atividades de assistência médica ao trabalho das unidades de saúde; 
- a incorporação de pessoal auxiliar no atendimento aos grupos prioritários: gestante e crianças e no controle de doenças transmissíveis;

- a visita domiciliar, realizada por visitador sanitário e auxiliar de saneamento, para atividades de promoção da saúde, prevenção de doenças, monitoramento de grupos de risco e vigilância sanitária;

- o tratamento supervisionado para o controle de doenças prevalentes, como a tuberculose;

- a organização de sistema de saúde regionalizado e hierarquizado: postos de saúde, unidades sanitárias, unidades mistas e hospitais;

- o enfoque intersetorial: a incorporação das atividades de saneamento básico ao trabalho das unidades, através da atuação do inspetor de saneamento e do engenheiro;

- a capacitação, em serviço, de profissionais e a preparação de pessoal de nível médio: laboratorista, auxiliar hospitalar, visitadora sanitária, guarda sanitário, auxiliar de saneamento, higienista dentária, ecônoma;

- a educação continuada para os profissionais;

- a educação para a Saúde;

- a integração docente-assistencial;

- o apoio às escolas de nível superior, em especial as de enfermagem, em quase todo o Brasil, para garantir formação dos profisssionais necessários às ações de saúde.

Entre as atividades das visitadoras sanitárias, auxiliar que desenvolvia o atendimento aos indivíduos e às famílias, na unidade e na comunidade, sob supervisão e orientação do enfermeiro, e mediante protocolos estabelecidos, para a prevenção da saúde, o monitoramento das doenças prevalentes, destacam-se:

- o atendimento a gestantes e crianças de baixo risco, na "unidade sanitária"; o primeiro atendimento da gestante era sempre um atendimento de enfermagem, ocasião em que a visitadora que avaliava as condições de desenvolvimento da gravidez, solicitava os exames definidos em protocolo, agendava esses exames, realizava pesquisa de albumina na urina e agendava o retorno com o médico para quando os exames estivessem prontos;

- as visitas domiciliares a puérperas e recém-nascidos;

- o acompanhamento de nascidos vivos e de óbitos de menores de 1 ano; 
- o monitoramento de pacientes portadores de doenças prevalentes;

As visitadoras sanitárias atuavam sob supervisão direta e orientação do enfermeiro. Elas tinham, quando fora da unidade, a responsabilidade pela cobertura da população residente em uma determinada área do município. $\mathrm{O}$ treinamento para o trabalho, com duração de 6 meses, realizado logo após a admissão, pelo enfermeiro, mediante programa validado pela instituição, desenvolvia as habilidades necessárias para as funções.

Em 1990, a F.SESP foi incorporada à SUCAM na constituição da Fundação Nacional de Saúde, do Ministério da Saúde.

O orgulho de toda uma geração de Sespianos é, provavelmente, devido ao fato de pertencer a uma escola pioneira em métodos e técnicas apropriados e que muito contribuiu para o aprendizado e para a saúde do povo brasileiro. Muitos desses sespianos assumiram posição de destaque, posteriormente, em proposições de modelos que visavam à extensão de cobertura a a reorientação do modelo de assistência à saúde, no Brasil. Segundo BASTOS, a F.SESP possibilitou a emergência de uma nova consciência em saúde pública no país e de vigorosas lideranças (BASTOS 1996).

Entende-se, assim, que qualquer trabalho que se proponha a estudar os modelos de reorientação da assistência à saúde no Brasil, necessariamente terá que passar pela história do SESP e da F.SESP.

1.1.1. O Programa de interiorização de Ações de Saúde e Saneamento - 1 $^{\text {a }}$ etapa - PIASS Nordeste - 1976-1979

O PIASS foi, entre os Programas de Extensão de Cobertura, aquele que, institucionalizado em nível de política governamental, conseguiu maior expressão. Além de absorver outros programas importantes, tais como o Programa de Integração de Serviços de Saúde do Norte de Minas, recobriu, em um primeiro momento, ampla região brasileira, o Nordeste, e acabou tornando-se objeto de uma proposta de expansão a outras áreas rurais do território nacional. O Programa foi instituído para a região Nordeste do País, pelo Decreto Presidencial de 24 de agosto de 1976, para o período 1976/1979, com a finalidade de implantar estrutura básica de saúde pública, nas comunidades de até 20.000 habitantes e de contribuir para a melhoria do nível de saúde da população da Região (ROSAS 1981). 
O PIASS propunha-se a adotar uma ampla gama de práticas que se estendiam desde as questões relacionadas ao meio ambiente até os problemas sanitários que demandassem atenção médica individual.

As diretrizes básicas do PIASS estavam expressas no artigo $2^{\circ}$ do Decreto:

"I - ampla utilização de pessoal de nível auxiliar, recrutado nas próprias comunidades a serem beneficiadas;

II - ênfase na prevenção de doenças transmissíveis, inclusive as de caráter endêmico, no atendimento de nosologias mais freqüentes e na detecção dos casos mais complexos, com vistas ao seu encaminhamento a serviços especializados;

III - desenvolvimento de ações de saúde caracterizadas por serem de baixo custo e alta eficácia;

IV - disseminação de unidades tipo miniposto, integradas ao sistema de saúde da Região e apoiadas por unidades de maior porte, localizadas em núcleos populacionais estratégicos;

$V$ - integração a nível dos diversos organismos públicos integrantes do Sistema Nacional de Saúde;

VI-ampla participação comunitária

VII - desativação gradual de unidades itinerantes de saúde, a serem substituidas por serviços básicos de caráter permanente.” (ROSAS 1981)

A participação comunitária aparecia, no texto, a um só tempo, como necessária e limitada. Derivava do caráter permanente e simplificado da estrutura a ser estabelecida em cada nível, para cuja sustentação a comunidade devia estar mobilizada. Essa mobilização orientava-se no sentido de garantir o apoio ao Programa e à execução, pela população local, de atividades necessárias à manutenção controlada dos custos e à própria operacionalização das ações previstas. Tal era o caso da participação proposta para: implantação de sistemas simplificados de abastecimento de água, de destinação de dejetos e do lixo; do suprimento mínimo de alimentos através do incentivo à formação de hortas e de pomares e à criação de animais de pequeno porte; custeio parcial, em nível local, das atividades em desenvolvimento. Para tal mobilização, encontrava-se previsto o treinamento de pessoal de nível auxiliar, no interior da própria estrutura de serviços. 
Todas essas proposições básicas parecem ter se tornado passíveis de algum grau de recomposição, em nível local, na dependência das características dos grupos envolvidos e dos processos ocorridos em nível central (DONNANGELO 1979). 
Evidentemente, esse processo, essas inflexões de diretrizes não se processaram sem marcados confrontos de tendências, tanto em nível central, como regional ou local. O processo de desenvolvimento do PIASS deve ser entendido como um processo político que reproduziu, em nível local, questões políticas sempre presentes na sociedade brasileira, como um todo e, em especial, nas localidades onde se implantaram.

Outros projetos e atividades também se estruturaram com vistas a proporcionar os necessários suportes para o desenvolvimento dessa nova política de atuação na área da saúde. Tal foi o caso do Programa de Preparação Estratégica de Pessoal de Saúde PPREPS - destinado a "adequar progressivamente a formação de recursos humanos para a saúde aos requerimentos de um sistema de serviços com máxima cobertura possivel e integral, regionalizado e de assistência progressiva, de acordo com as necessidades das populações respectivas e as possibilidades das diversas realidades que o país apresenta" (DONNANGELO 1979).

Criado em 1975, através de Acordo de Cooperação Técnica entre o Ministério da Saúde e a Organização Panamericana de Saúde, o PPREPS visava à preparação de recursos humanos adequados a um processo de extensão de cobertura subordinado às necessidades e possibilidades de diferentes áreas do país. Propunha, para tanto, a preparação, em larga escala, de pessoal de saúde de nível médio e elementar (DONNANGELO 1979).

A estratégia definida pela Coordenação do PIASS, para o ano de 1979, incluía como diretrizes básicas: operação e manutenção da rede básica já instalada; ampliação da rede, a fim de cobrir a totalidade dos municípios da área de abrangência do Programa, com vistas à sua consolidação; fortalecimento e reestruturação das Secretarias Estaduais de Saúde; busca da extensão do Programa para o âmbito nacional, para regiões cujas características dos habitantes e da oferta de serviços fossem análogas àquelas para as quais foi originário o Programa (Brasil, 1979). A 14 de novembro de 1979, foi efetivamente aprovada, através de Decreto Presidencial, a expansão nacional do PIASS, para o período 1980-1985.

\subsubsection{O PIASS - $2^{a}$ etapa - Expansão Nacional - 1980-1985. O PIASS no Vale do rio Ribeira, em São Paulo}


O Estado de São Paulo, através das regiões de Sorocaba e a do Vale do Ribeira, foi incluído, após negociações da Secretaria de Estado da Saúde - SES - com o Ministério da Saúde, na área de abrangência da expansão nacional do PIASS. Como decorrência, inicia-se, em 1981, o Projeto de Expansão de Serviços Básicos de Saúde e Saneamento em área rural, Vale do Ribeira, que contaria com recursos do Estado, do Ministério da Saúde e do ex-INAMPS (SILVA et al. 1986; São Paulo 1981). O Projeto DEVALE, como ficou conhecido, contava com Agentes de Saúde atuando em postos de saúde rurais e na comunidade, de 17 localidades rurais de 8 dos 16 municípios da Região (SILVA 1983). Entre 1983 e 1984, foi desenvolvida uma avaliação da implantação do Projeto DEVALE e do trabalho dos seus Agentes de Saúde, mediante financiamento do Ministério da Saúde em Convênio com a Universidade Estadual de Campinas (SILVA 1994).

Anteriormente, entre 1967 e1970, o Estado de São Paulo, assistiu, na gestão de Walter Leser, na Secretaria da Saúde, no processo da Reforma Administrativa, a um movimento de valorização da atenção básica, a uma política de programação da oferta de serviços de saúde. Se de um lado, essa política não previa o agente ou o auxiliar de saúde, por outro, incorporou, inspirado na F.SESP, o visitador sanitário, com algumas atribuições similares. Os desdobramentos dessa política, da identidade desse sujeito não serão objeto de discussão, neste trabalho. Cabe, também, em São Paulo, a lembrança, na perspectiva de política de uso de pessoal auxiliar, ao movimento dos Centros de Saúde-Escola, que objetivava ao desenvolvimento, nos alunos de graduação da saúde, da capacidade de atuar na atenção básica, com oferta organizada de serviços à população e participação de pessoal auxiliar na realização de várias das dimensões almejadas. Esse movimento foi estudado por CYRINO (1993), em tese de doutorado.

\section{O PIASS do Vale do Ribeira - O PROJETO DEVALE}

Também, anteriormente ao Vale do Ribeira, registraram-se, em São Paulo, importantes experiências de implantação de Programas de Agentes Comunitários de Saúde. Em meados da década de 70, a partir da eleição direta para prefeitos em cidades que não fossem capitais de estados ou consideradas como estratégicas, multiplicaramse, pelo país, iniciativas municipais para resolver demandas sociais emergentes e urgentes. Uma das áreas de escolha, pelos novos dirigentes, foi a da saúde. Assim, no 
estado de São Paulo, vários municípios implantaram programas dentro dos princípios da Atenção Primária à Saúde. Uma das vertentes dessas iniciativas municipalistas foram os programas de agentes de saúde, iniciativa que necessitou de bastante empenho e criatividade dos responsáveis, na medida da não existência de know how ou de estrutura oficial disponível para orientação. São José dos Campos é um dos municípios que dispõem dessa experiência, desde 1979.

A recuperação que aqui se fará do PIASS do Vale do Ribeira terá como fontes SILVA (1984) e SILVA et al. (1986). Até por essa razão, a caracterização desse programa poderá vir a ser mais completa que os demais em virtude de implicar vivência da pesquisadora com os fatos e os aspectos relatados. Em diferentes momentos, serão também utilizados depoimentos obtidos das referências acima indicadas.

"Eu estava em Juquiá, há quase quatro anos, fazendo todo um trabalho de morrer, de atender doentes. Atendendo doentes de manhã até a noite, e isso ... nós fomos vendo que resolvia muito pouco. Nós atendíamos as pessoas que ficavam mais próximas ao centro de saúde. As pessoas que não tinham acesso, tinham dificuldades enormes. Na hora em que chegavam ao centro de saúde, já não havia ficha. Nós fomos nos cansando deste tipo de atendimento, apesar de discutirmos outros tipos de atividades, de discussão da problemática de saúde, das condições de vida ... Apesar dessa agonia, estávamos sempre atendendo às mesmas pessoas".(técnico da Coordenação do Projeto DEVALE)

"Inclusive uma coisa marcou muito. O que aconteceu com uma família de desnutridos, porque a mãe, ela era de Barra do ... são mais de 32 quilômetros para chegar até aqui. As crianças estavam bastante desnutridas, demos o leite e explicamos que ela devia pegar o leite por mais tempo e a mãe falou assim: "Olha, a senhora não precisa me dar mais leite porque eu não tenho condições de chegar até aqui". Até para coisas assim tipo desidratação ... essas pessoas estavam sendo deslocadas. Eu tive um caso de uma criança que morreu por acidose, porque ela estava tão desidratada que o corpinho dela não resistiu e ela acabou falecendo; e foi por causa da distância. A mãe veio a pé, debaixo do sol, lá de Barra do ... para cá e não deu tempo da criança chegar aqui. Chegou já mortinha. E isso aí eu acho que devia ser freqüente, não só aqui, em todos lugares" (técnico da equipe de Coordenação do Projeto).

Um levantamento, realizado pela equipe, das condições de saúde e dos equipamentos da região deu origem a um relatório, por município, em que a equipe apresentava conclusões e sugestões. A ênfase maior recaía na garantia de acesso, na integração de recursos, no funcionamento das unidades e no atendimento à população da zona rural.

Essas providências, em nível regional, coincidiam com a época de apresentação, pela Secretaria Estadual da Saúde de São Paulo - SES, ao Ministério da 
Saúde, de um plano de trabalho denominado Plano Operativo Anual / POA, com vistas à assinatura de convênio entre os dois níveis de governo. As diretrizes do Ministério da Saúde para 1981, que incluíam a ênfase na operação da rede de serviços básicos de saúde, a participação comunitária, a regionalização, a horizontalização programática, a integralização de ações de saúde e o desenvolvimento de recursos humanos e de tecnologia simplificada e apropriada, fizeram com que esse plano de trabalho para o Vale do Ribeira integrasse o plano operativo desse ano, como um projeto prioritário a ser desenvolvido.

Foi então elaborado o "Projeto de Expansão dos Serviços Básicos de Saúde e Saneamento em Área Rural - Vale do Ribeira" - Projeto DEVALE- que, aprovado em nível federal, dava início à implantação do PIASS no Estado de São Paulo, em 1981.

Através do estudo detalhado do material disponível, dos objetivos, estratégias e desenvolvimento do Projeto, das entrevistas percebe-se a grande preocupação dessa equipe com determinados aspectos:

- a extensão de atividades de assistência primária à população residente na periferia dos centros urbanos e na zona rural, mediante a instalação de postos de saúde operados por agentes de saúde recrutados na própria comunidade;

“... levar para mais perto de onde as pessoas moram, trabalham, uma série de atividades ligadas à atenção primária que eram, até a época de implantação do Projeto, somente realizadas no centro de saúde do município”.

- a preparação da rede existente para servir de retaguarda à demanda gerada pelos postos de saúde;

- a coordenação das instituições de saúde existentes na área e o funcionamento integrado dos serviços;

- a integração entre as atividades de saúde e saneamento a serem desenvolvidas;

- a definição do sentido e dos limites das atividades do agente de saúde (esse aspecto aparece nas entrevistas com os técnicos integrantes da equipe de coordenação como de fundamental importância no desenvolvimento do Projeto);

- a viabilização de um espaço para discussão e organização da comunidade, em relação à problemática relacionada com a saúde.

"Você tem, de alguma forma, que levar a discussão para essas comunidades, tentar fazer com que as pessoas comecem a se juntar para discutir os problemas de saúde: porque eles existem; a causa desses problemas; porque toma remédio; melhora e 
depois fica doente de novo; os condicionantes ... E com isso estimular que eles vão procurando alternativas de resolver esses problemas do mais fácil para o mais difícil, do mais imediato ao mais mediato, sei lá, como eles achem que deveriam fazer. Mas eu acho que isso ai é tão importante quanto ... não é o caso de comparar, mas eu acho que uma coisa é a própria discussão de ter um posto aqui, por que é importante, sabe? Começando por aí, por uma coisa concreta que é a possibilidade de você ter um agente de saúde treinado no bairro e as possibilidades de você ter um local para as pessoas não só virem procurar atendimento ou orientação, mas também para conversar, trocar idéias, e com isso irem crescendo, organizando-se em função dos seus problemas de saúde, ou em função de outros problemas que eles achariam que têm ou não a ver com a saúde. Porque se a gente só pensar nesse objetivo de expansão de ações, de ação primária, desvinculando dessa outra problemática, dessa discussão, dessa experiência, dessa participação que tende a uma organização"(Diretor de Unidade de Saúde).

Embora não se tenha evidenciado uma preocupação em definir previamente as atividades a serem desenvolvidas pelo agente de saúde, em cada localidade rural, foi possível identificar três componentes principais que deveriam integrar o conjunto da prática do agente de saúde:

- um componente mais estritamente técnico, relacionado ao desenvolvimento de atividade em nível individual, de atendimento a queixas ou problemas;

- um componente relacionado às atividades em nível de comunidade;

- um componente relativo ao modo como deveria ser desenvolvido esse conjunto de atividades indicadas nos itens a e b.

Diferentes motivos, dentre os quais, a heterogeneidade dos locais onde o agente iria atuar, a localização do bairro em termos de acesso a serviços médicos e a proposta de que o agente de saúde e a população da localidade participassem dessa definição, fizeram com que o componente de conteúdo mais estreitamente técnico ficasse para ser determinado no treinamento dos agentes de saúde, ocasião em que seriam mais adequadamente consideradas as expectativas da população e do próprio agente, em relação ao trabalho a ser executado. Nessa perspectiva, detectou-se uma clara preocupação, por parte dos responsáveis pela operacionalização do Projeto, em não hipertrofiar a função considerada mais estritamente técnica, no atendimento individual, em detrimento das atividades coletivas, mesmo assumindo a necessidade daquele 
atendimento à demanda do cliente, devendo o seu caráter de prioridade ser definido na situação concreta.

A esse respeito, transcrevem-se a seguir trechos de entrevistas com técnicos da equipe de coordenação e diretores técnicos de centros de saúde da região.

"Quando a fome é muito grande e está apertando muito, a primeira necessidade é resolver aquela fome urgente daquele momento; então ela (a população) faz opção por aquelas pessoas que têm condições de resolver aquela fome urgente. Acho que no postinho o negócio é também por aí; quando você tem uma necessidade, um volume grande de atendimentos, de consultas ... o agente não abriu o postinho porque vai fazer reunião, não. Se a pessoa está com as crianças com diarréia, com não sei mais o quê, ela vai querer primeiro tratar a diarréia. Se o agente não está tendo tempo, ter um segundo agente, ter um terceiro agente naquele bairro. Então eu acho que não deve ser só essa função curativa, que é a reivindicação da população, é um direito dela. Mas nós devemos dar condições de trabalho para que o agente faça os dois papéis; coloca-se mais um agente para que ele possa desenvolver outras atividades".( técnico da Coordenação do Projeto)

"Eu acharia fundamental se a gente conseguisse desenvolver essa discussão sobre a problemática de saúde. Isso eu acho a "pedra de toque" do negócio. Agora, a gente vê que não é essa a expectativa do bairro. O bairro tem uma expectativa muito mais que seja uma pessoa que resolva os problemas de saúde, ou melhor, resolva os problemas de doenças. Eu acho que aí cabe à gente tentar fazer uma média das duas coisas. Tentar fazer com que o agente tenha condições de desenvolver aquelas atividades que o bairro considera que são atividades de atenção à saúde importantes, como por exemplo, picada de cobra, e além disso, essa atividade, que é mais que uma atividade, seria assim uma postura do agente de saúde frente aos problemas de saúde lá do seu bairro, discussão desses problemas, de tentar, juntamente com o bairro, encontrar as formas de encaminhar a solução desses problemas e essa outra parte, importante também, que é a reivindicação, a expectativa que o bairro tem do agente, que é a atenção aos problemas de saúde e aos problemas de doenças (...) Então há essas atividades como vacinação, primeiros-socorros em caso de corte, queimaduras, em caso de traumatismos por pancada, uma imobilização simples, acompanhar o desenvolvimento de crianças no primeiro ano de vida, acompanhar uma gestação, são coisas que, pela freqüência com que elas acontecem e pela importância que elas têm, 
acho que dá até para achar que são atividades importantes em todos os treinamentos, mas a maioria das coisas deve sair mesmo durante o treinamento. Agora essa atividade que eu acho importantíssima, que o agente estimule, que no bairro ocorra a discussão de problemática de saúde, que é inclusive a organização do bairro, que acaba envolvendo a organização em função de sua própria vida ... essa não é uma coisa que as pessoas do bairro esperam que o agente saiba fazer. Mas eu acho que a partir do próprio treinamento, quando o próprio agente começa a se interessar por essa discussão, sentindo a sua importância, ele consegue levar isso para o bairro." (técnico do equipe de Coordenação do Projeto)

“É que eles, em primeiro lugar, consigam levantar uma discussão sobre saúde no bairro ... Sobre os condicionamentos de saúde, por que as pessoas têm ou não têm saúde, por que aparecem tais ou quais doenças, quais as doenças mais importantes ... Depois, exercer um papel de educação ... partindo do que a própria comunidade vai conhecendo, vai colocando ... de descobrir um conhecimento junto ... de descobrir as maneiras de ter saúde ... de passar conhecimentos adquiridos. Também atender às pessoas, talvez tenha sido essa a idéia inicial ... por causa de falta de acesso das pessoas ... não há ônibus ou qualquer meio de transporte; quando há, a passagem é caríssima ... As ações de saúde estariam mais acessíveis às pessoas de zona rural. Então vacinação, suplementação alimentar e mesmo atendimento a doenças assim mais simples, que eles mesmos possam tratar ou com remédio que o postinho recebe ou com a própria medicina caseira que eles conhecem, chás ... Não assumir o papel de instituição ... Saber sempre o que estão fazendo e por que ... Não ver só a doença ou um pedaço do corpo ... ver a pessoa como um todo."

Sintetizando, a proposta de ação para o agente de saúde no Projeto em estudo incluía:

- proporcionar a extensão do atendimento aos problemas de saúde da população rural através da aplicação de conhecimentos e execução de atividades específicas (curativos, vacinas, diagnósticos e tratamento de doenças mais prevalentes, atendimento à criança e à gestante, encaminhamentos, primeiros socorros);

- contemplar uma visão global do indivíduo e desse na comunidade;

- incorporar um componente de discussão desses problemas de saúde em função das condições gerais de vida da população;

- organizar a comunidade para lutar pela saúde. 
A implantação dos postinhos e a seleção dos agentes de saúde - A escolha das localidades rurais onde seriam instalados os postos de saúde foi efetuada pela equipe de coordenação do programa, juntamente com os médicos dos centros de saúde, professores comunitários e prefeitos, tomando como referência o levantamento realizado nos municípios. Em uma primeira fase, foi definida a implantação em 17 localidades rurais pertencentes a 8 municípios da região. A razão da escolha desses municípios para o início do Projeto deveu-se à existência de médicos sanitaristas nos centros de saúde, o que propiciaria uma maior facilidade para o desenvolvimento da supervisão aos postos. Além disso, pelo fato de já terem participado das discussões quando da proposição do Projeto, teriam mais condições de modificar a estrutura dos centros de saúde, adaptando-os para servirem de referência aos clientes encaminhados pelos postos.

A partir das prioridades estabelecidas para a implantação das unidades de saúde, foram mantidos contatos com os professores comunitários, com os representantes da Igreja e com outros líderes, no sentido de realizar reunião dos moradores dos bairros indicados para discutir o posto de saúde e escolha do agente de saúde.

Em relação aos postos de saúde, quase sempre durante a reunião era constituída uma comissão, integrada pelo futuro agente de saúde e por outros moradores presentes, encarregada de tomar as providências relativas ao prédio.

Quanto ao processo de escolha dos agentes de saúde, de início, os moradores demoravam a acreditar que lhes caberia realmente a indicação da forma de escolha e a própria escolha do agente de saúde. Essa atitude pode estar relacionada com a época em que vivíamos -1981 - ainda sob o regime militar, sem a ocorrência de eleições diretas. Colocações como:

"...melhor seria que vocês mesmos escolhessem"; "vocês são médicos, enfermeiros, vocês é que sabem”, eram comuns em reuniões. Após a reação inicial de incredulidade, seguiram-se afirmações do tipo: "É bom mesmo a gente escolher, porque quem põe, tira!"

Dando início à escolha propriamente dita, o coordenador da reunião perguntava aos presentes sobre a opinião predominante a respeito de como deveria ser a pessoa que iria trabalhar no postinho. Essa colocação era sempre seguida de uma listagem, elaborada pelos presentes, de quais as qualidades que a pessoa deveria ter e quais os 
defeitos que não poderiam ser admitidos. Estavam, assim, sendo definidos, nessa oportunidade, os critérios para a seleção do futuro agente de saúde.

Alguns desses critérios foram lembrados em praticamente todas as reuniões, como por exemplo:

- "não fazer distinção entre as pessoas, tratar todo mundo igual pobre e rico, preto e branco, parente ou não parente, da mesma religião ou de outra";

- "saber ler e escrever" - este critério gerou ampla discussão entre os participantes: "Quanto mais estudo tiver, melhor"; "Se a gente for exigir muito estudo, no bairro não tem ninguém com muito estudo". Ao final, decidiram optar pelo nível de escolaridade oferecido pelo bairro;

- "ter jeito para a coisa";

- " "não ter medo de sangue";

- " "não ter medo de dar injeção";

- "ser responsável";

- "não ter orgulho";

- "ser maior de idade" - este critério variou muito nas diferentes reuniões; após as discussões, ficava acertado que o agente de saúde deveria ser de maior, desde que não fosse velho;

Em algumas localidades, outras qualidades foram julgadas necessárias:

- "comprometimento com a comunidade";

- "ter boa vontade";

- "ter tempo";

- "ser educado, calmo, atencioso";

- "ser decidido";

- "não beber";

- "andar ligeiro" - este critério reflete as precárias condições de transporte do Vale, prevendo que, na maior parte das ocasiões, os agentes teriam de se locomover a pé. A necessidade de o agente ser do bairro não foi manifestada, provavelmente, por estar implícita.

Em seqüência à listagem das qualidades do agente de saúde, eram sugeridos os nomes das pessoas que atendessem àqueles requisitos. Na maioria das localidades, após a indicação dos nomes, era procedida uma eleição, pelo sistema de votação secreta. Esse sistema foi igualmente escolhido pelos presentes, após muitas discussões: 
"Votação secreta é melhor, porque assim a gente fica mais à vontade, ninguém fica sabendo, nem fica chateado, cada um vota só com a sua cabeça e não vai votar porque o outro é primo, amigo ou parente".

Os votos eram, na maioria das vezes, colocados em urnas improvisadas, como chapéus de participantes. A apuração era sempre feita no local, com os eleitores servindo de fiscais de votação e de apuração.

Embora em todas as reuniões dos bairros, os moradores tivessem expressado claramente a opinião de que o agente de saúde poderia ser homem ou mulher, quando da escolha verificou-se absoluta maioria do sexo feminino (15 mulheres e 4 homens), apesar de terem concorrido candidatos de ambos os sexos, em todas as eleições.

A relação das qualidades necessárias ao agente, elaborada pelos moradores dos diferentes bairros, exprimiu, de certa forma, a expectativa geral frente ao trabalho a ser desenvolvido pelo mesmo.

O grau de instrução foi um dos temas mais debatidos nas reuniões, tendo ficado como opinião mais aceita a de que essa característica não tinha tanta importância pois, nos bairros rurais, não havia "pessoas muito instruídas". É interessante notar, entretanto, que a escolha recaiu, na maior parte das vezes, em pessoas que tinham um nível de escolaridade superior à média da população.

Outra característica geral dos agentes de saúde, que se pôde notar através das entrevistas, é a de terem sido escolhidas pessoas que já desempenhavam uma função similar à esperada para o agente. Em alguns casos, essas funções estavam já relacionadas à saúde: tratava-se de pessoas que eram habitualmente procuradas para dar orientações referentes a problemas de saúde ou para prestar serviços como aplicação de injeções, realização de curativos, etc. Na maioria dos casos, porém, as pessoas selecionadas já desenvolviam algum tipo de atividade comunitária, tais como as realizadas na igreja (clube de mães, clubes de jovens), pelas escolas comunitárias ou as decorrentes de associações civis voluntárias e informais, relacionadas com a discussão de problemas comuns.

O treinamento dos Agentes do DEVALE - Para os futuros instrutores, de acordo com a proposta de trabalho definida para os agentes de saúde e as características do Projeto e da região onde este seria implantado; algumas preocupações em relação ao treinamento já se impunham: 
- o treinamento teria que atender à proposta de atividade a ser desenvolvida pelo agente de saúde, ou seja, deveria possibilitar aos treinanandos o instrumental necessário (conhecimentos, técnicas de metodologia de trabalho) à realização das diversas dimensões do trabalho a ser executado na comunidade. Desse modo, o treinamento deveria abranger não apenas a aquisição de conhecimentos, mas também o desenvolvimento da capacidade crítica de análise, a motivação para pensar junto com o bairro, caminhar junto, discutir e tentar resolver os problemas em conjunto. Para que esse objetivo múltiplo fosse alcançado, no desenvolver do trabalho de cada um, era antes necessário que fosse percebido e exercitado no próprio treinamento;

- o conteúdo do treinamento deveria respeitar fundamentalmente os aspectos que o agente de saúde trouxesse como reivindicações, como expectativas do bairro em relação à sua atuação. Na medida do possível, o agente deveria ser capacitado a atender a essa demanda;

- como conseqüência, os conhecimentos e técnicas a serem apreendidos, pelos agentes, deveriam ser definidos durante o treinamento. Essa preocupação não incluía, entretanto, a renúncia por parte dos técnicos à habilitação dos agentes para o efetivo trabalho com os problemas de saúde conhecidos como mais prevalentes na região, ou para a execução das atividades previstas nos programas e subprogramas da SES/SP;

- a metodologia a ser adotada deveria garantir uma participação ativa dos treinandos, no sentido de proporcionar uma troca de conhecimentos, experiências e modos de ver e pensar entre alunos e instrutores;

- o processo de capacitação desses agentes não deveria afastá-los do seu bairro mas, pelo contrário, procurar mantê-los como elementos do grupo social a que sempre pertenceram;

- o treinamento inicial, previsto para dois meses, não seria suficiente para a capacitação do agente; etapas posteriores de continuidade do processo deveriam, portanto, ser asseguradas.

O modelo de treinamento sugerido visava a atingir duas preocupações básicas: $1^{\mathrm{o}}$ - fortalecer o compromisso e a solidariedade do agente de saúde com a comunidade; 
$2^{\circ}$ - prover condições para a apropriação, pelo agente de saúde, do instrumental adequado e necessário para lidar com os problemas de saúde desse grupo.

A metodologia proposta, na tentativa de privilegiar o como manter ou aumentar o compromisso do agente de saúde com a população, durante a capacitação, visava proporcionar o desenvolvimento de competências para conhecer criticamente as situações de saúde no contexto da realidade em que elas apareciam e buscar um saber que correspondesse à necessidade de mudar tais situações.

Em termos metodológicos, no sentido de promover o desenvolvimento do processo ensino/aprendizagem, a proposta em discussão traduzia-se no recurso à uma série gradual e encadeada de situações. Esse recurso visava a proporcionar condições para que houvesse uma integração entre o que os treinandos traziam como experiência anterior de vida e os conhecimentos que lhes seriam transmitidos durante $o$ treinamento. Da mesma forma, os conteúdos deveriam ser construídos a partir dos saberes dos alunos, o que facilitaria o salto quantitativo dos conhecimentos $\mathrm{e}$ comportamentos já existentes para os comportamentos e habilidades necessários ao trabalho.

Com base nessas considerações, o treinamento dos agentes de saúde do Vale do Ribeira constituir-se-ia na etapa inicial do processo de ensino/aprendizagem destes agentes, processo esse que deveria ter seu seguimento durante o desenvolvimento de sua prática nas localidades rurais.

Finalmente, os instrutores consideravam que, para o encaminhamento das questões centrais relativas ao processo de aprendizagem - quais as formas de conhecer e pensar das pessoas a serem capacitadas e qual a estrutura do conhecimento que deveria ser assimilado - teriam que conduzir o treinamento tendo em mente alguns princípios fundamentais:

- procurar ver saúde no contexto geral de vida;

- identificar as formas de conhecer e de pensar das pessoas;

- partir do conhecimento que as pessoas têm do problema;

- compreender a importância do diálogo na comunicação e no processo ensino/aprendizagem;

- procurar aprender com os outros;

- devolver, sempre, ao interessado o resultado de qualquer estudo; 
- reforçar o grupo no encaminhamento dos problemas;

- refletir, continuamente, sobre o trabalho realizado.

O treinamento dos agentes de saúde do Vale do Ribeira teve a duração de 12 semanas, sendo 10 na sede do treinamento e nas localidades rurais e 2 de estágio prático, nos Centros de Saúde de cada município.

A primeira semana de treinamento teve como atividades a apresentação pelos alunos dos problemas de saúde dos seus bairros, a discussão sobre a situação dos prédios onde iriam funcionar os postos, em cada localidade, e a apresentação da história de cada bairro.

Na seqüência, em termos de grupo, a necessidade que se colocava era: como fazer para conhecer os problemas do dia-a-dia do bairro? Como ficar sabendo o conhecimento que as pessoas têm dos problemas? As idéias foram surgindo, sendo discutidas e, ao final, foram sintetizadas em uma espécie de roteiro, que expressava, de forma geral, o modo como o agente de saúde deveria trabalhar na comunidade e o tipo de trabalho a ser desenvolvido.

\section{Como fazer o trabalho no bairro:}

1. Ter boa comunicação na hora de conversar com as pessoas do bairro.

2. Partir do conhecimento das pessoas do bairro e não dos seus próprios conhecimentos.

3. Aprender uns com os outros.

4. Devolver as perguntas às pessoas do bairro. Não tentar dar respostas prontas.

5. Dar tempo para as pessoas pensarem.

6. Juntar o maior número possível de pessoas do bairro quando discutir um problema.

7. Não se afastar das pessoas do bairro.

8. Partir dos problemas do dia-a-dia do bairro.

9. Conhecer melhor os problemas do bairro, através de:

- visitas às casas;

- reuniões;

- pesquisas (procurar fazer este trabalho em grupo);

- conversar descontraída, sem perguntas prontas;

- não deixar que as anotações atrapalhem a conversa.

10. Devolver ao bairro os resultados dos levantamentos dos problemas.

11. Tentar resolver, juntos, os problemas. 
12. Escolher, juntos, o que fazer em cada momento.

Uma vez elaborado o roteiro sobre "como fazer o trabalho no bairro", os alunos sentiram a necessidade de decidir sobre quando voltariam ao bairro para realizar o levantamento utilizando a metodologia discutida. Os treinandos passaram, então, toda a semana seguinte nos seus bairros, desenvolvendo o estudo. Após o retorno, foram feitos os relatos, cada aluno de uma vez.

O levantamento realizado, além da tentativa de conhecer quais os efetivos problemas de saúde que as pessoas identificavam, visava a colher informações referentes às causas às quais eram atribuídos esses problemas e ao modo como cuidavam deles. O levantamento foi feito utilizando visitas às casas e reuniões; as visitas, realizadas em grande número de residências, serviam também como preparo da reunião. Eram colocados os objetivos do trabalho, feitas algumas perguntas e acertados o dia e a hora da reunião, ocasião em que os moradores presentes discutiam amplamente os problemas, seu modo de encará-los e suas possíveis soluções. Um tema bastante solicitado nas reuniões era o conteúdo que os alunos estavam aprendendo no treinamento.

Os dados obtidos nas entrevistas nos domicílios eram ou não anotados, dependendo da receptividade da família; os assuntos levantados nas reuniões, entretanto, eram sempre registrados.

Durante as apresentações do levantamento, os instrutores procuravam identificar diferentes aspectos: como foi realizado o estudo, qual o número de casas visitadas, como foram recebidos, como foi iniciada a conversa, de que forma os moradores colocaram os problemas, como se desenvolveu a conversa, quantas pessoas compareceram à reunião, como esta se processou, como foi a participação das pessoas, como o aluno sentiu o trabalho, que dificuldades e problemas teve, como os encaminhou.

$\mathrm{Na}$ tentativa de sistematizar os resultados do levantamento e planejar as demais etapas do trabalho, os instrutores solicitaram aos alunos um relatório individual, sendo para isso elaborado um roteiro com sete questões.

1. Quais as dificuldades que você encontrou para ter uma boa comunicação com as pessoas do bairro?

2. Quais os principais problemas que encontrou nas visitas? 
3. Quais os principais problemas levantados nas reuniões e quais as conclusões a que o bairro chegou?

4. No levantamento que você fez, apareceu algum fator novo que tem influência na saúde?

5. O que você acha importante aprender para poder ajudar a resolver os problemas do bairro?

6. Como você se sentiu fazendo esse levantamento?

7. O que você acha que o bairro pensou desse levantamento, da reunião e dos resultados da reunião?

Após a leitura das respostas relativas a cada questão, na dependência da sua natureza, eram retiradas as conclusões, feitos agrupamentos por analogia do assunto, ou desenvolvida uma síntese das respostas.

As respostas à pergunta $n^{0} 5$ foram, na realidade, o ponto inicial para seleção do conteúdo a ser aprendido no treinamento, pois já representavam uma síntese dos problemas que os alunos percebiam na comunidade, dos problemas relatados pelos moradores por ocasião das vistas e nas reuniões realizadas nos bairros.

A síntese dos relatórios individuais gerou uma listagem contendo 90 problemas de interesse. A natureza dos assuntos variava grandemente, desde dor de barriga, dor em volta do umbigo, até problemas de posse de terra, passando por doenças de senhoras, verminose, realização de partos, nefrite e outros.

Frente a essa diversidade, os alunos foram divididos em quatro grupos na tentativa de agrupar os problemas que tivessem, em sua opinião, algumas afinidades entre si.

Os agrupamentos sugeridos pelas quatro equipes foram reagrupados em 18 grandes grupos de problemas, os quais abrangeram todos os noventa relacionados na primeira descrição.

\section{Concepções dos agentes de saúde do Projeto DEVALE sobre a sua prática - no} estudo realizado por SILVA (1984), os agentes de saúde foram unânimes, durante as entrevistas, em concluir pela importância do trabalho que estão desenvolvendo em relação à melhoria das condições de saúde das populações das localidades rurais onde atuam.

A forma de expressão dessas conclusões, entretanto, variou bastante. Pode-se atribuir essa variação, observando-se o registro dos depoimentos, às diferentes concepções de que eram portadores esses agentes acerca do sentido de seu trabalho. 
"Foi por causa das dificuldades das pessoas de tomar ônibus para ir à cidade sabe? É muito longe! As pessoas perdiam o ônibus, chegavam lá não tinha mais horário de consulta, perdiam tempo ... Aí resolveram instalar esse postinho aqui. Foi devido a esses problemas".

“... saiu esse projeto aí, que até botaram cartaz em armazém, venda, que ia ter uma inscrição, sabe, porque o lugar é um pouquinho maior e eles resolveram ..." "Porque resolveram fazer? Acho que é porque é longe da farmácia, né? Pra chegar na farmácia mais próxima é $8 \mathrm{~km}$. Então não tem recurso nenhum. Eu acho que foi por isso (...) Eu acho que foi um levantamento mesmo do pessoal da saúde pública".

“Ah, porque falta de condições, né? Pro pessoal ir à cidade tratar sua saúde ... Aí, resolveu fazer o postinho".

"Olha, eu ... Foi porque ... porque fica muito longe, né? Pra ir daqui pra cidade, né? (...) E a turma aqui, o pessoal não tem assim uma condição, sabe?, financeira, de tar tomando ônibus pra ir pra lá. Como já acontece muito, que vem aqui no postinho, chega aqui, ai eu dou uma guia de exames, qualquer coisa, já não pode ir porque a situação financeira já não tá legal. Então, não dá pra ir, não é?, e fica mais perto".

"Penso que é pela quantidade de gente que procura os médicos lá em ..., e tudo. Então eles viram que a maior necessidade era aqui ..., porque não é brinquedo a quantidade de gente que vai. Agora já diminuiu porque muita coisinha, eu estou resolvendo aqui mesmo ... mesmo sem o remédio, só com chá caseiro (...) Já não precisa eles pagar ônibus, nem nada, e doente, né?, é duro pegar ônibus doente".

Ao avaliarem a importância do trabalho por eles realizado, os agentes de saúde distinguiam duas dimensões: uma primeira, que se referia à satisfação pessoal experimentada, pelo sentimento de sua utilidade, pela consciência de sua contribuição para minorar as dificuldades que a população rural enfrenta; e uma segunda, relacionada à própria população e ao significado que o trabalho teria para ela. Em relação à primeira dessas dimensões:

"A gente fica contente porque vê que ajuda uma pessoas que necessita, né?"

"A gente sente-se bem, pois está trabalhando pelos outros, não é? Tem muita gente que precisa, que precisa da gente ..."

"Eu gosto. Eu gostei do negócio. Eu gosto de tratar crianças".

"Eu sempre pensava em ajudar em alguma coisa aqui do bairro ... Aí saiu isso e deu certo".

"Meu sonho desde criança era esse trabalho". 
Ainda em relação a essa primeira dimensão, percebe-se a consciência dos agentes no que diz respeito às propostas elaboradas para o seu trabalho, mesmo que as observações sobre a prática tenham revelado muitas limitações neste sentido:

"Eu acho que é muito importante ensinar para as pessoas o que eu sei ... e o que elas sabem também ensinam, porque tem coisa que a gente não sabe, aprende com os outros".

“... é a oportunidade que a gente tem de trabalhar com o bairro, aprender com ele, conviver com ele, ver as necessidades dele, sentir mais os problemas do bairro".

Por referência à segunda dimensão, aquela relacionada às necessidades da população, percebe-se primeiramente a idéia de estarem resolvendo ou encaminhando os problemas de saúde:

"No início, a gente era inseguro .. agora, ninguém fala em médico aqui".

"O posto ajuda porque fica mais perto das pessoas".

"O trabalho é importante porque a gente lida com a comunidade .. a gente orienta eles..."

"A gente aqui explica tudo direitinho ... Na farmácia eles só passam remédios, a pessoa nem fica sabendo para que serve”.

"O estado de saúde da população melhorou muito devido às orientações que a gente pode dar, como no caso das fossas".

“O posto ajuda o pessoal, porque eles não precisam gastar dinheiro".

"A população reclama muito quando o posto fica fechado, quando a gente sai para fazer visitas”.

"Ainda não conseguimos chegar ao ideal, porque é difícil, mas já melhorou bastante".

Percebe-se, por outro lado, a idéia de que seu trabalho, para a população, ultrapassa as dimensões do mero atendimento às necessidades, possibilitando a abertura de um espaço onde outros problemas de saúde passavam a ser discutidos e encaminhados, onde as pessoas começavam a falar juntas sobre seus problemas.

"O trabalho do postinho vai além do atendimento. eles se reúnem aqui, falam o que sentem, o que eles querem ..., já têm aquela liberdade ..."

"A gente aqui trabalha com a vontade do bairro".

"As pessoas do bairro têm mais liberdade de discutir os seus problemas com os agentes do que em outros lugares". 
"As pessoas se sentem mais à vontade no atendimento".

"A gente ensina para as pessoas tudo o que aprendeu no treinamento".

Os agentes de saúde também foram unânimes em afirmar que a população estava satisfeita com o funcionamento dos postos. Justificavam essa afirmação pelo fato de a demanda aumentar, a cada dia, e pelos comentários que a população fazia sobre o atendimento recebido. Consideravam que a população confiava, cada vez mais, no trabalho desenvolvido e que vários fatores contribuíam para isso, sendo o mais importante a forma como eram tratados durante o atendimento e, conseqüentemente, a oportunidade de que dispunham para falar dos seus problemas. Essa confiança no trabalho dos agentes traduzia-se, ainda, segundo os mesmos, no atendimento às suas prescrições e no comparecimento, quase maciço, aos retornos agendados.

"Antes, a população procurava só leite e remédios, não sabiam do atendimento. agora, já s acostumaram".

"Eu acredito que a população gosta do trabalho porque cada vez aumenta mais gente, em vez de diminuir".

"Eles gostam do jeito porque a gente deixa eles mais à vontade, eles conversam entre si bastante, contam as necessidades deles, papeiam às vezes com as outras pessoas que vêm junto ... (...) ... e a gente também vai explicando as perguntas, conversando, dando risada, porque isso dai sempre foi o meu tipo, assim ... nessa base”.

"A primeira coisa que eu fiz depois que eu voltei dos dois meses de treinamento, eu fiz uma visita assim no bairro, explicando o problema que eu tinha estudado ... eu fui de casa em casa explicando tudo e perguntando qual os problema que você tem aqui. E marquei uma reunião ... então veio um bocado de gente. Então eles achavam que o maior problema que tinha aqui era o esgoto. Porque tem uma vala que atravessa o bairro todo e o esgoto cai dentro dessa vala e estava inundando tudo, e o esgoto estava tomando conta ... e tinha que limpar aquilo ali. Então foi feito um mutirão para limpar e abrir aquela vala, e dai por diante eles me viram trabalhando e ficaram sabendo, por causa dessa reunião que eu fiz".

"Antes eles perguntavam, no começo, quando ia vir médico, se ia vir médico uma vez por semana ... agora não tem mais esse negócio de médico, eles não procuram médico aqui, quando que vem médico, quando não vem ..."

O treinamento e a conseqüente habilitação proporcionada para o desenvolvimento das atividades era avaliado em termos muito positivos. Entendiam que foi suficiente 
para resolver a maioria dos problemas, mas não se mostraram capazes de detectar as insuficiências.

Ao analisar, nesse mesmo estudo, o trabalho desenvolvido pelos agentes, SILVA (1984), comparou as freqüências com que eram tomados os diversos tipos de conduta em relação aos motivos de demanda, pela população, e chamou a atenção, sobretudo, para uma baixíssima freqüência com que apareciam os tipos "prescrição de dietas terapêuticas" e "orientações preventivas", especialmente, se comparadas com a freqüência de prescrições de medicamentos industrializados. Mais notável, entretanto, considerava a autora, era a quase ausência, no padrão de trabalho terapêutico dos agentes, da orientação preventiva. Eram consideradas como condutas pertencentes a este tipo, todo o conjunto de orientações para a promoção de saúde (aí incluídas as discussões sobre as relações entre saúde e todos os tipos de determinantes tão intensa e extensamente presentes no treinamento), todas as medidas de higiene, nucleares no tratamento das doenças infecciosas e parasitárias e todas as medidas de prevenção específica e reabilitação dos agravos à saúde.

Também quando da análise das entrevistas com a população, a autora não evidenciou nenhum padrão de resposta indicativo da eventual captação de proposta integral de trabalho para o agente de saúde, conforme colocada anteriormente, em termos de seus três componentes básicos; a grande maioria da população entrevistada explicitou um tipo de resposta indicativo de captação da proposta apenas no seu componente de atendimento médico.

Entretanto, as informações obtidas com as entrevistas com a população confirmaram que os postos de saúde eram realmente procurados e valorizados e os agentes de saúde bem conceituados pela competência e dedicação com que desenvolviam o seu trabalho. Nas conclusões do trabalho, a autora discute as condições que poderiam estar relacionadas às eventuais inadequações verificadas no trabalho desenvolvido pelos agentes.

Em primeiro lugar, o fato de o Departamento Regional de Saúde da SES não ter incorporado adequadamente o Projeto às suas atividades. Ao contrário, pelas informações disponíveis, à Direção do Departamento não interessava o desenvolvimento do Projeto, na medida em que o consideravam como um veículo para o desenvolvimento de atividades "subversivas". Assim, a idéia inicial de que o Projeto DEVALE viria a se constituir na própria programação de trabalho do Departamento 
Regional de Saúde do Vale do Ribeira, até o período observado (março de 1983), não chegou a se concretizar. O Projeto foi mantido e sobreviveu graças ao empenho da equipe de Coordenação. Esse fato teria influenciado a forma como se desenvolveram, na prática, algumas atividades de apoio vitais à efetiva implantação do Projeto.

Como decorrência do acima indicado, foram relacionados limites institucionais, entre os quais, a sistemática de desenvolvimento de determinadas atividades que não atendiam à forma e ao espírito do Projeto, dificultando a operacionalização do mesmo através de um processo de orientações conflitantes e, às vezes, até opostas. Dentre os limites institucionais, mereceram destaque a forma de supervisão adotada em relação aos postos de saúde e a descontinuação do processo de treinamento, entre outros.

A sistemática de supervisão adotada em relação aos postos de saúde parecia, a partir de uma rápida análise, sugerir que essas atividades eram insuficientes, no aspecto quantitativo pelo menos, para o pleno cumprimento dos objetivos, entre os quais elevar a qualidade dos serviços prestados e contribuir para o aperfeiçoamento do pessoal. E ainda, insuficientes para a sua utilização como estratégia de planejamento, organização das unidades, treinamento do pessoal, desenvolvimento de educação continuada e avaliação dos serviços prestados.

O modo como era realizada essa atividade constituía-se em fator ainda mais limitante quando se considerava o seu desenvolvimento distante das situações reais de trabalho do agente de saúde e das dificuldades relatadas pela equipe de Coordenação do Projeto quanto à disponibilidade de recursos materiais, entre as quais se destacam as atinentes a veículos e combustível, entre outras de diferentes naturezas, que forçaram, às vezes, a diminuição das já tão escassas oportunidades de encontro entre agentes e supervisores, para a discussão do trabalho.

Por seu lado, o processo de capacitação dos agentes de saúde, imaginado originalmente como um processo que incluiria uma primeira fase de treinamento na sede do Departamento Regional de Saúde e uma outra de continuidade em nível das localidades rurais, deixou de ter essa segunda fase desenvolvida. A idéia era que, na segunda etapa, se prosseguiria a discussão - utilizando os mesmos métodos, sobre os mesmos conteúdos, mas valendo-se agora do recurso às situações concretas de atendimento - visando à complementação da capacitação do agente, tanto para os atendimentos individuais como para o trabalho com a comunidade. 
Para os agentes de saúde do Vale do Ribeira, o treinamento não avançou além da primeira fase. Esse fato, aliado às dificuldades operacionais para realizar a supervisão, relatadas pela equipe de coordenação, permite conduzir a conclusões parciais acerca da importância das limitações institucionais na explicação das inadequações detectadas na prática dos agentes de saúde, se referenciado o estudo dessa às propostas que a originaram.

Outras dificuldades relatadas podem ser consideradas como impondo limites às práticas dos agentes: a ausência de equipamentos para o atendimento a crianças, a gestantes, a irregularidade no fluxo de material de consumo e de medicamentos.

O agente de saúde do DEVALE, não dispondo, muitas vezes, do instrumental básico necessário ao desenvolvimento das atividades para as quais começou a ser treinado, e não encontrando, igualmente, espaço para discutir seu trabalho nas condições reais em que este se desenvolvia, dificilmente poderia reproduzir, em seu padrão de trabalho, as propostas que originaram o Projeto e que nortearam o treinamento. $\mathrm{O}$ apreciado padrão de trabalho, apesar de suas diversas insuficiências, era mantido graças a um grande esforço, que implicava, freqüentemente, o desgaste pessoal.

A análise dos registros das observações referentes ao relacionamento do agente com a clientela referiam, na totalidade dos casos, a existência de um clima de confiabilidade, amizade e descontração, do qual não estava ausente o respeito mútuo, indicando, em mais uma dimensão, a aplicação com que o agente procura desempenhar suas funções.

“A medida em que esses e aquela nunca tiveram acesso regular e ampliado a serviços de saúde, tendem a compartilhar uma mesma expectativa em relação a eles. Pode dar-se que as posições críticas e "pedagógicas" que nortearam o Projeto queimem etapas em relação a essas expectativas, isto é, não seja possível o desenvolvimento de uma cultura que relativize a efetividade dos cuidados "médicos" sem antes conhecê-los e utilizá-los. As entrevistas feitas com os agentes, assim como as feitas com a população, mostram uma identificação entre as melhora das condições de saúde e o conhecimento/utilização dos recursos tecnológicos da medicina; se essa identidade pode ser relativizada de uma perspectiva crítica mais global, que parte inclusive da experiência acumulada com o uso em larga escala daqueles recursos, é muito dificil alcançar esse tipo de concepção a partir da carência quase total deles. Isto não invalida, entretanto, de forma alguma, as bases conceituais que presidem o 
andamento do Projeto, mas pode apenas significar, mais provavelmente, que o tempo de manutenção requerido para que uma avaliação identificasse seu pleno desenvolvimento não tenha sido ainda alcançado" (SILVA et al. 1986).

\subsubsection{Programa de Agentes Comunitários de Saúde do Estado do Ceará - PACS-Ceará - 1987}

Para caracterização do PACS do Ceará e dos aspectos relacionados com o Agente de Saúde foram utilizados dados e informações obtidos de diferentes fontes, em especial de Relatório de Projeto de Avaliação coordenado pela Secretaria de Saúde do Estado do Ceará, estudo de caso desenvolvido, em 1999, por MINAYO, M.C. et al. com o apoio do Fundo das Nações Unidas Para a Infância - UNICEF, cujo objetivo era identificar os fatos mais importantes gerados no processo de implementação do "Programa Agentes de Saúde do Ceará", em especial:

- a potencialidade da proposta com relação à saúde da população;

- as mudanças em alguns indicadores de cobertura de ações de saúde;

- a qualidade das ações executadas pelos Agentes de Saúde;

- as mudanças nas atitudes e no comportamento das comunidades em relação à proteção à saúde;

- $\quad$ as mudanças na situação de saúde da população alvo.

Segundo o Relatório do estudo referido, a idéia de implantar Programa que incorporasse Agentes de Saúde já fazia parte do Plano de Governo do Estado, em 1987, no Ceará. A ocorrência de seca de inusitadas proporções e a decisão de abertura de "frentes de trabalho" para a população de diferentes regiões do Estado, em estado mais crítico, precipitou o início do Programa. Nessas circunstâncias, o Estado identificou a possibilidade de empregar, a curto prazo, em atividades de promoção da saúde, milhares de moradores de áreas carentes, cuja remuneração seria garantida com os recursos dos fundos especiais de emergência, destinados pelo Governo Federal. (MINAYO el al. 1990).

Ainda segundo o Relatório, entre setembro de 1987 e agosto de 1988, 6.113 pessoas foram contratadas - 95\% mulheres - em 118 municípios do sertão cearense. Após treinamento de duas semanas, elas trabalharam, durante 6 a 12 meses, desenvolvendo ações básicas de saúde: terapia de reidratação oral, vacinação, orientação para estímulo ao aleitamento materno, entre outras. 
“Algumas características das providências tomadas nesta contingência diferenciaram a ação governamental da rotina dos últimos 30 anos. As decisões sobre a seleção do pessoal que receberia salário, que deveria ser o mais pobre, e sobre as obras e atividades para serem executadas, foram tomadas por "Grupos de Ação Comunitária”- G.A.C.- interinstitucionais, especialmente constituídos. Foi contratado um número limitado de pessoas com relação ao passado, chegando-se ao máximo de 235.000 no primeiro trimestre de 1988, à razão de um por família. O pagamento das pessoas cadastradas foi em dinheiro e não em mercadorias. Um "salário mínimo" foi o valor da remuneração mensal, igual para todos, sensivelmente superior à média local. As atividades executadas, em sua grande maioria, foram em áreas públicas ou de propriedade de pequenos agricultores, evitando-se beneficiar grandes proprietários e dirigindo-se a muitas pequenas obras de interesse comunitário"(MINAYO et al. 1990).

É nesse contexto, que acontece, no Ceará, a primeira experiência de trabalho em ampla escala com agentes comunitários de saúde, "representando uma tentativa de trabalhar para o desenvolvimento e para o futuro, mesmo numa crise aguda, na qual o objetivo primordial era a sobrevivência”.(MINAYO 1990)

Com o fim do período mais crítico de estiagem, o Programa de Governo mais amplo foi sendo desativado. O Programa dos Agentes de Saúde, entretanto, teve outro destino. As manifestações das comunidades assistidas e as ponderações dos técnicos levaram o Governo do Estado a concluir pela manutenção e expansão do programa, agora financiado com recursos do Tesouro do Estado (MINAYO et al. 1990).

Assim, o Programa de Agentes de Saúde do Ceará iniciou a sua implantação em 45 municípios do interior do Estado, entre setembro de 1988 e julho de 1989. Através de documentos oficiais da SES e de outras fontes, os autores do Estudo de Caso, identificaram os objetivos do Programa, as atribuições dos Agentes de Saúde, bem como outros aspectos de interesse para a caracterização da Proposta, aspectos esses aqui reproduzidos:

O Objetivo Geral do Programa, seria: melhorar a capacidade da comunidade de cuidar da sua própria saúde.

Os Objetivos Específicos, de algum modo, expressavam a expectativa em relação à atuação dos agentes de saúde: reduzir o risco de morte ligado ao parto para a mãe e a criança; aumentar a proporção de mães que alimentam os seus filhos 
exclusivamente ao seio até 4 meses de vida; reduzir os óbitos causados pela desidratação resultante da diarréia.

O Programa era previsto para, em cada um dos municípios contemplados, atender toda a população.

Outra idéia-chave do Programa era "empregar, em áreas entre as mais pobres do Estado, um número relevante de mulheres que assim melhorariam a sua condição social e possivelmente, estimulariam um posicionamento mais ativo de outras mulheres na sociedade".

Quanto às ações a serem desenvolvidas pelos agentes de saúde, eram relacionadas:

“Visitar regularmente (pelo menos uma vez por mês) as famílias da área e, com maior intensidade, as que têm crianças menores de 2 anos e gestantes, para: ensinar conhecimentos úteis, incluindo nutricionais, para prevenção e atenção precoce a agravos; fornecer medicamentos antitérmicos; executar curativos de feridas, pesagens periódicas das crianças menores de 2 anos (com acompanhamento na curva de crescimento) e medição do perímetro braquial das gestantes. Haveria o acompanhamento de 50-100 famílias nas áreas rurais e 150-250 nas áreas urbanas por agente.

Encaminhar às Unidades de Saúde para diagnóstico e terapia, para controles preventivos, particularmente pré-natal, e para prevenção do câncer gineco-obstétrico; encaminhar às Unidades de Saúde para vacinação.

Promover, organizar ou colaborar com reuniões da comunidade, para discutir e enfrentar assuntos de saúde. Promover, organizar ou colaborar com atividades na própria comunidade, como vacinação ou obras de saneamento" (MINAYO et al. 1990).

Os agentes deveriam trabalhar com outros membros da comunidade que, tradicionalmente, já executam ações de saúde, como as parteiras leigas, os curandeiros locais e outros agentes. Também havia a indicação de promover uma atitude ativa e participativa das famílias e da comunidade para a proteção da saúde.

Em termos de seleção, na medida em que os Agentes não poderiam ser contratados mediante um concurso público convencional, eles seriam eleitos pela comunidade local. 
Treinamento e Supervisão dos Agentes de Saúde do Ceará -Cada grupo de 20 ou 30 Agentes estava vinculado a um supervisor de nível superior em dedicação exclusiva ou, no mínimo, por 20 horas semanais de trabalho. O treinamento incluía uma capacitação inicial de 60 dias, sob responsabilidade da supervisão municipal, a qual daria ênfase em ações de educação e de promoção da participação comunitária.

A implementação rapidamente atingiu os 45 municípios, selecionando 1.701 agentes de saúde, atendendo a mais de 170 mil famílias, chegando a cobrir uma população de 850 mil habitantes (13.8\% do Estado), em julho de 1989. Em setembro de 1990, o Programa já atuava em 84 municípios, com 2.905 agentes que cobriam 290.000 famílias e, aproximadamente, 1.450 .000 habitantes (23.5\% do Estado; 33\% do interior). Nos municípios em que atuavam, os agentes cobriam uma parcela significativa da população, de 40 a $100 \%$, com média aproximada de $80 \%$.

Vínculo e Aspectos Financeiros - No começo do Programa, o vínculo de trabalho foi efetivado através de Bolsa, paga pelo Tesouro Estadual.

Os Resultados positivos apontados pelo estudo de MINAYO et al., em termos de ampliação do acesso das pessoas, da importância e da presença dos agentes nas comunidades, da confiança que lhes depositava a população, da atitude e do compromisso evidenciado no trabalho, bem como na melhoria de determinados indicadores como cobertura vacinal, controle de câncer cérvico-uterino, indicadores de qualidade do trabalho e até na redução de doenças preveníveis por imunização, na queda da mortalidade infantil por diarréia foram muito importantes para a continuidade e ampliação do Programa, no Estado e no País e para a proposição, pelo Ministério da Saúde, do Programa Nacional de Agentes Comunitários de Saúde - PNACS. Também as recomendações acerca das dificuldades e os principais desafios apontados pelo Relatório foram importantes no processo.

\subsubsection{Programa Nacional de Agentes Comunitários de Saúde - PNACS -} Fundação Nacional de Saúde - FNS - Ministério da Saúde - MS - 1991

O PNACS teve seu início em 1991, na região nordeste do Brasil. Em uma $2^{\text {a }}$ fase, contemplou parte da região norte. A idéia inicial era que, em 1992, o PNACS entraria na periferia das grandes capitais e áreas carentes que, ao longo dos anos, vinham propiciando altas taxas de morbi-mortalidade. 
A justificativa para implantação do Programa prendia-se à existência de inúmeras "experiências de atenção primária" em quase todo o Brasil, aos excelentes resultados alcançados, por muitos deles, ao integrar o agente à equipe, não apenas como um elo entre o Sistema de Saúde e a população mas, principalmente, por sua capacidade de resolver ou evitar parte dos problemas que ocasionavam o congestionamento do sistema de assistência à saúde.

Referiam também a significativa contribuição dos ACS, ao oferecer procedimentos simplificados de ações de saúde voltados para práticas de medicina preventiva, para a diminuição da morbi-mortalidade no Brasil e, por conseqüência, para o Sistema Único de Saúde. Também serviram de referência para o Ministério da Saúde assumir o Programa, as avaliações de impactos positivos em outros locais, entre os quais, o Ceará, o Vale do Ribeira, São Paulo e a contribuição dos agentes no combate à epidemia de cólera.

Como propósito do Programa, através do apoio técnico e financeiro às iniciativas estaduais e municipais na implantação de Projetos de ACS, a contribuição rumo à municipalização e a um Sistema Único de Saúde hierarquizado, regionalizado e com possibilidade de acesso universal. Também visava a estender a cobertura dos sistemas públicos de saúde às populações rurais e das periferias urbanas, priorizando a população materno infantil.

O Objetivo Geral era expresso como melhorar, através dos Agentes Comunitários de saúde, a capacidade da população de cuidar de sua saúde, transmitindo-lhe informações e conhecimentos, além de proporcionar a ligação entre a comunidade e os serviços de saúde locais.

Os Objetivos Específicos: capacitar os ACS para executar trabalhos de primeiro nível de atenção à saúde, garantindo cuidados à população com um grau de resolubilidade compatível com sua função, contribuindo para a extensão da atenção à saúde; garantir o trabalho do ACS integrado com a equipe da Unidade de saúde a que estivesse vinculado; fortalecer a ligação entre serviços de saúde e comunidade; ampliar o acesso à informação sobre saúde na comunidade; cooperar com a organização comunitária, no trato com os problemas de saúde.

Em documento de orientação e treinamento dos Agentes de Saúde, o Trabalho do Agente Comunitário de Saúde, datado de junho de 1994, identificam-se os princípios que geraram a idéia do Programa: 
- um programa estratégico para contribuir na redução da mortalidade materno-infantil;

- um instrumento para provocar a discussão da organização e ou reorganização dos Sistemas Locais de Saúde - Silos;

- um aglutinador de forças sociais para viabilizar a criação e ou a implementação dos Conselhos Municipais de Saúde;

- um mecanismo concreto para a interiorização de enfermeiros e, sobretudo;

- uma ponta de lança para mobilização e organização das comunidades.

O Programa destinava-se a municípios cuja população apresentasse altos índices de morbi-mortalidade e a populações residentes em áreas rurais e em periferias urbanas, em bairros carentes.

A área de atuação inicial do PACS foi a região Nordeste, onde assumiu como prioridades do trabalho do agente ações de educação em saúde, de mobilização da comunidade e de atenção ao grupo materno-infantil. Na região Norte, no entanto, a implantação do PACS ocorreu em caráter emergencial, para fazer frente à epidemia do cólera.

Com base na experiência do Ceará, foram definidos os mecanismos de seleção dos agentes: ter mais de 18 anos, saber ler e escrever, dispor-se a concluir o $1^{\circ}$ grau, morar há mais de 2 anos na comunidade, dispor de 8 horas por dia para o trabalho.

O recrutamento e a seleção dos ACS eram desenvolvidos em 8 fases:

- preparação das Coordenações Estadual, Municipais e articulação com o Conselho Municipal de Saúde

- mobilização em que os coordenadores municipais articulam-se, mobilizam a comunidade e divulgam o processo

- inscrição

- elaboração da prova

- aplicação da prova escrita

- realização de entrevistas (individuais e grupal)

- classificação e publicação dos resultados

- contratação como bolsista

Após essas fases, verificava-se o treinamento dos Coordenadores Regionais e dos Instrutores - Supervisores Municipais, a organização e o Treinamento dos Agentes. 
Nos documentos do Ministério que normatizam o PNACS é explicitada a preocupação da Coordenação Nacional do Programa com a desvinculação de qualquer ingerência político-partidária no processo de recrutamento e seleção dos ACS, condição de suma importância para o bom desempenho desse Programa Nacional.

Treinamento dos agentes - Os agentes teriam uma capacitação que lhes permitisse uma visão abrangente da situação de saúde e habilitação específica para atenção à saúde da comunidade.

O processo de aprendizagem do ACS não implicava apenas o domínio das técnicas das ações básicas de saúde; fazia-se necessário que o mesmo compreendesse a sua comunidade, entendesse seus problemas e a estimulasse a modificar sua relação com a saúde.

Assim, o conteúdo da capacitação corresponderia às ações e atividades a serem desenvolvidas e o método pedagógico seria o da integração ensino/trabalho.

O documento: Curso de Formação de Agentes Comunitários de Saúde Roteiro de atividades para o Coordenador Municipal de Saúde - foi elaborado pela Coordenação Nacional com a colaboração de vários coordenadores estaduais, para os coordenadores municipais. Nele são explicitados os princípios que norteiam o processo de capacitação dos agentes.

O Conteúdo do Programa de Treinamento Inicial incluía:

\section{- Capítulo 1 - O agente comunitário de saúde - um agente de mudança}

A primeira parte, saúde pretendia que o agente aprendesse a conceituar saúde, com a finalidade de identificar e analisar as condições de saúde da sua comunidade. Para isso ele precisaria "aprender o que é saúde e quais as condições de vida que promovem ou deixam de promover a saúde"

A segunda parte, saúde e vida comunitária visava a possibilitar que os alunos aprendessem a conceituar vida comunitária, visando a estabelecer a relação entre vida comunitária e a promoção da saúde.

A terceira parte, as atividades do agente comunitário de saúde.

As ações propostas para o agente eram consideradas de reconhecida utilidade e eficácia, para diferentes comunidades. Poderiam, entretanto, ser adaptadas e/ou ampliadas de acordo com a realidade de cada Estado, região ou município, assim como com a situação epidemiológica, a cada momento. Os 3 eixos principais de atuação dos agentes: educação e saúde, mobilização da comunidade e atenção ao grupo maternoinfantil era assim expresso nas seguintes ações propostas:

- estimular continuamente a organização comunitária; 
- participar da vida da comunidade, principalmente através das organizações, estimulando a discussão das questões relativas à melhoria da qualidade de vida;

- fortalecer os elos de ligação entre a comunidade e os serviços de saúde;

- informar aos demais membros da equipe de saúde da disponibilidade, necessidades e dinâmica social da comunidade;

- orientar a comunidade para utilização adequada dos serviços de saúde;

- registrar nascimentos, doenças de notificação compulsória e de vigilância epidemiológica e óbitos ocorridos;

- cadastrar todas as famílias de sua área de abrangência;

- identificar e registrar todas as gestantes e crianças de 0 a 6 anos de sua área de abrangência, através de visitas domiciliares;

- executar, dentro do seu nível de competência, ações e atividades básicas de saúde:

- acompanhamento a gestantes e nutrizes

- incentivo ao aleitamento materno

- acompanhamento do crescimento e desenvolvimento da criança

- garantia do cumprimento do calendário de vacinação e de outras vacinas que se fizerem necessárias

- controle das doenças diarreicas

- controle da Infecção Respiratória Aguda -IRA

- orientação quanto a alternativas alimentares

- utilização da medicina popular

- promoção de ações de saneamento e melhoria do meio ambiente

- promoção da educação em saúde

A quarta parte: a importância do trabalho do agente comunitário de saúde.

\section{Capítulo 2 - O Agente Comunitário de Saúde mobilizando a Comunidade}

\section{Capítulo 3: o Agente Comunitário de Saúde Conhecendo a Comunidade}

Para o treinamento citado acima foi elaborado o "Manual do Agente Comunitário de Saúde". O Coordenador/supervisor do ACS deveria ser enfermeiro, que deveria dispor de, no mínimo, 20 horas semanais para o Programa. 
Uma preocupação muito evidente da Coordenação do Programa dizia respeito aos processos de treinamento e educação continuada. E não apenas com a questão técnica mas, principalmente, com o componente político do programa. Nesse sentido, para apoio aos instrutores supervisores enfermeiros que eram responsáveis pelos agentes, nos municípios, foram elaborados muitos manuais e, principalmente, textos de apoio ao trabalho. Assim, O trabalho do Agente Comunitário de Saúde, editado em 1991, desenvolve um detalhamento sobre conceitos e como trabalhar com saúde, o que é o agente, como trabalhar com a comunidade e fazer o diagnóstico comunitário. Ou seja, representava um instrumento orientador das ações a serem desenvolvidas no primeiro nível de atenção à saúde. Uma $2^{\text {a }}$ edição desse manual, em 1994, foi o produto de revisão da qual participaram todos os Coordenadores Estaduais e Assessores do PACS. Na $3^{\text {a }}$ edição, já em 2000, identificam-se alterações de conteúdo nesse guia de capacitação, as quais se propõem a atender à evolução do trabalho dos agentes e contemplar a inserção em equipes de saúde da família.

Por seu lado, o Texto de Apoio Ações Básicas de Saúde e Desenvolvimento da Criança, além de ensinamentos sobre o SUS, Direitos Sociais e Cidadania, o papel do ACS nesse processo, o detalhamento de conceitos e orientações de atividades de: desenvolvimento da criança, aleitamento materno, cuidados com o recém-nascido, imunização, controle de doenças diarreicas, controle de infecções respiratórias agudas.

"Ao estimular a formação dos agentes, não se pretende que eles venham a substituir ou preencher o papel de outros profissionais de saúde que lutam no sentido de garantir uma melhor assistência à população. Acredita-se que por serem pessoas do povo, não só se assemelham nas características e anseios deste povo, como também preenchem lacunas, justamente por conhecerem as necessidades desta população.

Acredito que os agentes são a mola propulsora para a consolidação do Sistema Único de Saúde, a organização das comunidades e a prática regionalizada e hierarquizada de assistência, na estruturação dos distritos sanitários.

Ser agente de saúde é ser povo, é ser comunidade, é viver dia a dia a vida daquela comunidade.

É passar pela rua, pela favela, pelo barraco e sentir que o seu povo necessita do seu trabalho e com o seu trabalho, ela pode ajudar a viver melhor...(....)

$\dot{E}$ conhecer todas as famílias e sentir em todas elas a sua família. É sentir que os filhos de todas as mães são um pouco seus filhos...

É ser o elo de ligação entre as necessidades de saúde da população e o que pode ser feito para melhorar suas condições de vida.

É ser a ponte entre a população e os profissionais e serviços de saúde.

O Agente Comunitário é o mensageiro de saúde de sua comunidade." (Dirigente da Fundação Nacional de Saúde, 1991) 
A principal estratégia de preparação de agentes comunitários de saúde estaria baseada na mobilização da comunidade, que deveria respaldar o desenvolvimento e o fortalecimento do trabalho cotidiano dos mesmos. A informação e a discussão do PNACS com a comunidade eram colocadas como os principais meios para isso, sendo que a sensibilização das comunidades deveria permear todas as etapas de implantação do Programa.

Interação e relacionamento com a estrutura profissional

O Fórum de Entidades Nacionais da Enfermagem - composto pela Associação Brasileira de Enfermagem, Conselho Federal de Enfermagem, Federação Nacional dos Enfermeiros e União Nacional dos Auxiliares e Técnicos de Enfermagem integrava, desde 1991, a Comissão Consultiva à Coordenação Nacional do PNACS para elaboração do ante-projeto do PNACS e, em articulação com a Coordenação Nacional, participava do acompanhamento, avaliação e supervisão da implantação do PNACS.

A preocupação das entidades nacionais da enfermagem de que a incorporação de agentes comunitários de saúde para o desenvolvimento de ações básicas de saúde, algumas delas identificadas com as da enfermagem, pudessem significar um aumento do contingente de trabalhadores sem qualificação, como os atendentes, levou-as a assumir uma posição de questionamento e até de enfrentamento ao Ministério da Saúde.

Se inúmeras foram as oportunidades de negociação, tanto nos Estados quanto em nível federal, alguns foram os entendimentos. Compromisso assumido pela Fundação Nacional de Saúde, do Ministério da Saúde, garantia às entidades da enfermagem que, após a capacitação inicial dos agentes em Ações Básicas de Saúde, mobilização e educação sanitária, haveria continuidade do processo de formação, com a finalidade de habilitá-los em Auxiliar de Enfermagem Comunitário. Deveria também ser viabilizada, mediante entendimentos com o sistema educacional, a continuidade da escolaridade para nível de $1^{\circ}$ grau, paralelamente à formação profissionalizante, atendendo ao que estabelece o Conselho Federal de Educação e a Lei 7.498 de 25 de junho de 1986, que regulamenta o exercício da enfermagem, no País. Termo de Compromisso, inclusive de responsabilidade sobre o financiamento da formação, foi assinado, em Brasília, em agosto de 1991, pela Presidenta da Fundação Nacional de Saúde e pelos Dirigentes das Entidades Nacionais de Enfermagem: Conselho Federal de Enfermagem, Associação Brasileira de Enfermagem e Federação Nacional dos 
Enfermeiros (Anexo 1.1). Esta pesquisadora esteve presente ao ato de assinatura do Termo.

\section{Concepção sobre sua identidade de agente}

"Ser Agente Comunitário de Saúde é, antes de tudo, ser alguém que se identifica, em todos os sentidos, com a sua própria comunidade, principalmente na cultura, linguagem, costumes; precisa gostar do trabalho. Gostar, principalmente, de aprender e repassar as informações, entender que ninguém nasce com destino de morrer ainda criança ou de ser burro. Nós vivemos conforme o ambiente.

É preciso ver que saúde não é só uma coisa de doutor e que favelado tem que cuidar de saúde, sim.

É obrigação dos Agentes Comunitários de Saúde lutar e aglomerar forças em sua comunidade, município, estado e país, em defesa dos serviços públicos de saúde, pensar na recuperação e democratização desses serviços, entendendo que é o serviço público que atende à população pobre; é preciso torná-lo de boa qualidade.

Precisamos lutar por outros fatores que são determinantes para a saúde como: trabalho, salário justo, moradia, saneamento básico, terra para trabalhar $e$ participação nas esferas de decisão dos serviços públicos". (Agente Comunitária de Saúde - Recife)

Em 1992, o PNACS perdeu o termo nacional, passando a chamar-se PACS. Foram celebrados convênios entre a FNS/MS e as Secretarias Estaduais de Saúde para repasse de recursos para custeio do programa e para o pagamento, sob a forma de bolsa, no valor de um salário mínimo, mensalmente, aos agentes.

Em 1993, o PACS já abrangia 13 estados das regiões Norte e Nordeste, com 29.000 Agentes Comunitários de Saúde, atuando em 761 municípios. A estratégia definida previa a ampliação, em 1994, para novos municípios das regiões norte e nordeste e estendido também, para a Região Centro-Oeste do Brasil.

Em novembro de 1994, foi desenvolvida uma avaliação, em 8 estados onde o Programa se desenvolvia. A avaliação, realizada com o apoio da UNICEF, era coordenada pela Secretaria Estadual e executada por universidades. Na ocasião, o Programa já se encontrava-se implantado em 987 municípios do país, de 17 estados das regiões norte, nordeste e centro-oeste, e incluía um total de 33.488 Agentes.

A idéia da coordenação nacional era que, um olhar externo, especialmente das universidades, pudesse identificar os pontos positivos e as necessidades de ajustes e reorientações.

O documento Avaliação Qualitativa do PACS descreve o estudo desenvolvido, entre setembro a novembro de 1994, cuja metodologia incluiu entrevistas com os usuários. Entre os vários aspectos positivos apresentados, citam o reconhecimento dos 
usuários pelo trabalho do ACS, reflexos importantes na cobertura vacinal, na terapia de reidratação oral, no início precoce dos exames pré-natais, no conhecimento dos agentes pelo nome, quando comparados os dados obtidos para população coberta e não coberta pelo ACS. Ao lado das evidências positivas, o relatório da pesquisa sugere necessidade do aprimoramento do processo de supervisão dos Agentes e da formação profissional desses últimos. Além desses aspectos, o relatório aponta para uma articulação insuficiente do ACS com outros profissionais e com os serviços de saúde, e do programa com o Sistema de Saúde dos Municípios onde está implantado.

\subsubsection{Programa de Saúde da Família - PSF - FNS/MS -1994}

O Programa de Saúde da Família foi concebido em 1993, e oficializado em 1994, mas a sua expansão nacional efetiva ocorre a partir de 1995 (Viana \& Dal Poz,1998). Desde os seus primeiros documentos, a concepção do programa era de fazê-lo um instrumento de reorganização do SUS e da municipalização, estando definido que sua implantação deveria privilegiar áreas de maior risco social. A partir de 1995, são definidos e institucionalizados mecanismos e patamares de financiamento e muitos municípios passam a se interessar pelo Programa, particularmente, mas não exclusivamente, aqueles com uma estrutura de atenção básica ainda pouco desenvolvida.

Em final de 1993, foi divulgado, pelo Ministério da Saúde, o primeiro documento sobre o Programa de Saúde da Família - PSF, resultado de uma reunião com vários Secretários Estaduais e Municipais de Saúde, professores universitários, especialistas e técnicos.

O PSF é apresentado, nessa primeira versão, como um modelo de assistência à saúde que visa a desenvolver ações de promoção e proteção à saúde do indivíduo, da família e da comunidade, através de equipes de saúde, que farão o atendimento na unidade local de saúde e na comunidade, no nível de atenção primária.

Pontos principais da Proposta: 
Organização - Cada equipe básica do PSF seria responsável pela cobertura de uma área geográfica onde habitem de 800 a 1.000 famílias. Este critério poderia ser alterado, em função das condições de acesso e da densidade demográfica do município.

As equipes do PSF seriam compostas por um médico, um enfermeiro, um auxiliar de enfermagem e 4 a 6 agentes de saúde. A estrutura das equipes poderia ser modificada de acordo com a realidade local. Caberia ao Silos garantir a supervisão e a atualização dos profisssionais.

A equipe do PSF deveria residir na comunidade onde iria atuar e trabalhar em regime de dedicação exclusiva. Posteriormente, tendo em vista as discussões, esse critério de residência, ficou como obrigatório apenas para o Agente Comunitário de Saúde.

As equipes não deveriam atuar isoladamente, mas buscar, sempre que possível, a parceria com os diversos segmentos da sociedade. Para garantir a participação ativa da comunidade deveriam ser desenvolvidas ações de educação e promoção da saúde, com a difusão permanente de informações.

Casa pessoa da família receberia atenção integral da equipe do PSF, independentemente da idade e do estado de saúde. As equipes seriam responsáveis pela execução de ações para prevenção do aparecimento e do aumento da incidência de doenças.

O PSF seria a porta de entrada ao sistema de saúde em todas as localidades onde estivesse implantado.

Perfil dos Profissionais - A formação básica dos profissionais de saúde integrados ao PSF deveria ser direcionada para esse modelo de atenção, que exige qualificação técnica e identificação com os objetivos do trabalho.

O controle da qualidade de serviços prestados pelo PSF e a avaliação do desempenho profissional da equipe de saúde seriam exercidos por grupos de supervisão, pelos Conselhos de Saúde e pelas comunidades atendidas.

Os Objetivos do PSF - 1a. Versão - 1993

Geral: Melhorar o estado de saúde da população através de um modelo de assistência, voltado à família e à comunidade, que inclua desde a proteção e a promoção da saúde até a identificação precoce e o tratamento das doenças. 


\section{Específicos:}

- divulgar o conceito de saúde como qualidade de vida e direito do cidadão;

- promover a família como o núcleo básico da abordagem no atendimento à saúde da população, num enfoque comunitário;

- prestar atendimento básico de saúde, de forma integral, a cada membro da família, identificando as condições de risco para a saúde do indivíduo;

- proporcionar atenção integral, oportuna e contínua à população, no domicílio, em ambulatórios e hospitais;

- agendar o atendimento à população, com base nas normas dos programas de saúde existentes, sem descartar a possibilidade de atendimentos eventuais e domiciliares;

- humanizar o atendimento e estabelecer um bom nível de relacionamento com a comunidade;

- organizar o acesso ao sistema de saúde;

- ampliar a cobertura e melhorar a qualidade do atendimento no sistema de saúde;

- promover a supervisão e a atualização profissional para garantir boa qualidade e eficiência no atendimento;

- levar ao conhecimento da população as causas que provocam as doenças e os resultados alcançados na sua prevenção e no seu tratamento;

- incentivar a participação da população no controle do sistema de saúde.

População alvo - O PSF seria implantado, prioritariamente, nas áreas delimitadas no Mapa da Fome do IPEA, de acordo com as características geográficas e a distribuição da população, em cada município.

A escolha deveria, também, observar os seguintes critérios:

- realização de mapeamento das áreas do município indicadas para a implantação do Programa;

- interesse da comunidade em participar do PSF;

- necessidades de saúde locais; demanda por serviços;

- oferta atual de serviços;

- existência de apoio para o diagnóstico e tratamento de doenças, consultas especializadas e hospitais que assegurem o atendimento adequado e a eficiência do Programa; 
- disposição da administração municipal em adotar o modelo de assistência à saúde proposto pelo PSF e em participar do seu financiamento.

A participação social - As equipes de saúde do PSF deveriam trabalhar de forma integrada com a comunidade. Assim, seria possível aumentar a participação das organizações populares no planejamento, execução e avaliação do Programa e contribuir para o controle social das ações e serviços de saúde.

As instituições privadas e as entidades sem fins lucrativos também deveriam ser estimuladas a colaborar com o Programa, fornecendo material para as unidades de saúde e moradia para os profissionais do PSF.

\section{O treinamento e a supervisão dos profissionais}

A identificação de um dos principais desafios para realização do Programa, a capacitação dos membros das equipes, levou o Ministério a incentivar a organização de Pólos Regionais de Capacitação, um movimento de articulação com as Universidades. Por outro lado, também investiu, em especial nas articulações e na produção de material didático para a capacitação dos agentes comunitários de saúde.

Documentos do Ministério da Saúde, de 1997 e 1998, reforçam o entendimento do PSF como uma estratégia para organização da atenção básica à saúde, no País. "O objetivo do PSF é a reorganização da prática assistencial em novas bases e critérios, em substituição ao modelo tradicional de assistência, orientado para a cura de doenças no hospital. A atenção está centrada na família, entendida e percebida a partir do seu ambiente físico e social, o que vem possibilitando às equipes de Saúde da Família uma compreensão ampliada do processo saúde/doença e da necessidade de intervenções que vão além de práticas curativas" (MS 1998).

Quanto aos princípios que norteiam a atuação das Unidades Básicas sob o enfoque de saúde da família, são referidos:

- caráter substitutivo: substituição das práticas convencionais de assistência por um novo processo de trabalho, cujo eixo está centrado na vigilância à saúde;

- integralidade e hierarquização: estar inserida no primeiro nível de ações e serviços do sistema local de saúde e vinculado à rede de serviços, de forma a garantir a referência e contra-referência sempre que forem requeridas ações mais especializadas; 
- territorialização e adscrição de clientela: trabalhar com território de abrangência definida e população cadastrada, recomendando-se que cada equipe seja responsável, no máximo, por 4.500 pessoas;

- equipe multiprofissional: cada equipe de Saúde da Família deverá ser composta, minimamente, por um médico generalista ou médico de família, um enfermeiro, um auxiliar de enfermagem e de quatro a seis agentes comunitários de saúde.

O documento "Saúde da Família: uma estratégia para a reorientação do modelo assistencial," reforça pontos centrais do Programa:

- o estabelecimento de vínculos e a criação de laços de compromisso e de coresponsabilidade entre os profissionais de saúde e a população. Segundo o documento, essa perspectiva faz com que a família passe a ser o objeto precípuo de atenção, entendida a partir do ambiente onde vive. "Mais que uma delimitação geográfica, é nesse espaço que se constroem as relações intra e extrafamiliares e onde se desenvolve a luta pela melhoria das condições de vida-permitindo, ainda uma compreensão ampliada do processo saúdeldoença e, portanto, da necessidade de intervenções de maior impacto e significação social. As ações sobre esse espaço representam desafios a um olhar técnico e politico mais ousado, que rompa os muros das unidades de saúde e enraize-se para o meio onde as pessoas vivem, trabalham e se relacionam “(MS 1997).

- O PSF caracteriza-se como uma estratégia que possibilita a integração e promove a organização das atividades em um território definido, com o propósito de propiciar o enfrentamento e resolução dos problemas identificados.

Ainda nessa publicação, o Ministério nega e justifica a negação à identificação do PSF como um sistema de saúde pobre para os pobres, com utilização de baixa tecnologia. "Tal assertiva não procede, pois o Programa deve ser entendido como modelo substitutivo da rede básica tradicional - de cobertura universal, porém assumindo o desafio do princípio de eqüidade - e reconhecido como uma prática que requer alta complexidade tecnológica nos campos do conhecimento e do desenvolvimento de habilidades e de mudanças de atitudes".(MS 1997)

Os Objetivos do PSF, segundo documento do Ministério da Saúde, de 1997: 


\section{"Geral}

Contribuir para a reorientação do modelo assistencial a partir da atenção básica, em conformidade com os princípios do Sistema Único de Saúde, imprimindo uma nova dinâmica de atuação nas unidades básicas de saúde, com definição de responsabilidades entre os serviços de saúde e a população.

\section{Específicos}

- Prestar, na unidade de saúde e no domicílio, assistência integral, contínua, com resolubilidade e boa qualidade às necessidades de saúde da população adscrita.

- Intervir sobre os fatores de risco aos quais a população está exposta.

- Eleger a família e o seu espaço social como núcleo básico de abordagem no atendimento à saúde.

- Humanizar as práticas de saúde através do estabelecimento de um vínculo entre os profissionais de saúde e a população.

- Propiciar o estabelecimento de parcerias através do desenvolvimento de ações intersetoriais.

- Contribuir para a democratização do conhecimento do processo saúde/doença, da organização dos serviços e da produção social da saúde.

- Fazer com que a saúde seja reconhecida como um direito de cidadania e, portanto, expressão da qualidade de vida.

- Estimular a organização da comunidade para o efetivo exercício do controle social" (MS 1997).

\section{As Atribuições do Agente Comunitário de Saúde}

'O ACS desenvolverá suas ações nos domicílios de sua área de responsabilidade e junto à unidade para programação e supervisão de suas atividades.

\section{Suas atribuições básicas são:}

- realizar mapeamento de sua área de atuação;

- cadastrar e atualizar as famílias de sua área;

- identificar indivíduos e famílias expostos a situações de risco;

- realizar, através de visita domiciliar, acompanhamento mensal de todas as familias sob sua responsabilidade; 
- coletar dados para análise da situação das famílias acompanhadas;

- desenvolver ações básicas de saúde nas áreas de atenção à criança, à mulher, ao adolescente, ao trabalhador e ao idoso, com ênfase na promoção da saúde e prevenção de doenças;

- promover educação em saúde e mobilização comunitária, visando uma melhor qualidade de vida mediante ações de saneamento e melhorias do meio ambiente;

- incentivar a formação de conselhos locais de saúde;

- orientar as famílias para a utilização adequada dos serviços de saúde;

- informar os demais membros da equipe de saúde acerca da dinâmica social da comunidade, suas disponibilidades e necessidades;

- participação no processo de programação e planejamento local das ações relativas ao território de abrangência da unidade de Saúde da Família, com vistas à superação dos problemas identificados”.(MS 1997)

Em documento datado de 1999, o Ministério da Saúde conceitua atenção básica como um conjunto de ações, de caráter individual ou coletivo, situadas no primeiro nível de atenção dos sistemas de saúde, voltadas para a promoção da saúde, a prevenção dos agravos, o tratamento e a reabilitação. A ampliação desse conceito é considerada necessária para avançar na direção de um sistema de saúde centrado na qualidade de vida das pessoas e de seu meio ambiente. A organização da Atenção Básica é relacionada à Lei $\mathrm{n}^{\circ}$ 8.080, e aos princípios do SUS: saúde como direito; integralidade da assistência; universalidade; eqüidade; resolutividade; intersetorialidade; humanização do atendimento; participação popular.

Em dezembro de 1998, após cinco anos de funcionamento, o PSF estava implantado em 24 estados (ausente em Roraima, Amapá e Distrito Federal), 1.219 municípios, com 3.119 equipes. Avaliação desenvolvida pelo Ministério da Saúde em 1999, demonstrou que 83\% dos municípios implantaram o PSF entre 1997 e 1998, sendo que apenas o Ceará e Santa Catarina têm um número maior de municípios com implantação anterior a 1997. É também o Ceará, juntamente com Minas Gerais, que apresenta uma maior número de municípios com o programa em atividade (MS 1999).

No estado de São Paulo, segundo dados da Secretaria Estadual de Saúde, são referidos, até o final de 1999, 111 municípios com o PSF e 98 municípios com o PACS, abrangendo um total de 2725 agentes comunitários de saúde e 237 equipes de saúde da família. 
O número acima referido, entretanto, não inclui o Município de São Paulo, pois o PSF em funcionamento não está vinculado ao Município e sim ao Estado, em decorrência de opção política municipal por outro sistema, o PAS. O Programa de Saúde da Família, no Município de São Paulo, que teve início em 1996, recebeu a denominação de Projeto QUALIS - Qualidade Integral em Saúde - e, embora calcado no modelo dos PSF, apresenta particularidades, por referência à proposta nuclear, tanto em relação à forma de gestão, operacionalizada através de parcerias do Estado com Organizações Sociais, quanto à organização das atividades assistenciais, ao se inserir em um nova realidade, uma metrópole como São Paulo.

A Vinculação Institucional dos Agentes - Na época da publicação do último documento referido, a contratação dos agentes, a sua vinculação continuava sendo um dos pontos de maior preocupação, tendo em vista a necessidade de mantê-los na sua comunidade e ao mesmo tempo de proporcionar-lhes as garantias da legislação do trabalho. Muitos foram os movimentos do Ministério da Saúde, mas essa situação ainda é uma das pendências.

Em dezembro de 1997, Portaria Ministerial estabelece a prioridade, no Plano de Metas do Ministério da Saúde, para os Programas de Agentes Comunitários de Saúde e de Saúde da Família, estimulando a sua expansão. Reconhece ainda, a referida Portaria, o PACS e o PSF como importantes estratégias "para contribuir no aprimoramento e na consolidação do Sistema Único de Saúde, a partir da reorientação da assistência ambulatorial e domiciliar". No mesmo instrumento, são aprovadas Normas e Diretrizes para o PACS e o PSF, entre as quais, diretrizes operacionais para o trabalho dos Agentes Comunitários de Saúde, nos dois programas.

Uma tentativa de síntese das propostas apresentadas, utilizando os dados de que se dispõem, poderá identificar pontos importantes em cada uma delas, ou pontos comuns a algumas delas, aspectos nucleares da conformação da identidade do agente de saúde. Os aspectos discutidos nessa síntese serão retomados na Discussão dos Resultados tendo em vista a discussão de sua identidade e a identificação de analogias e especificidades entre os sujeitos de propostas anteriores e os agentes comunitários de saúde do QUALIS, em São Paulo. Assim, estarão sendo identificadas "tipologias de agente comunitário" que existiram, em determinados momentos e contextos históricos.

$\mathrm{Na}$ realidade, quando se analisam, numa primeira aproximação, as propostas colocadas, identificam-se, de um lado, características básicas comuns e, de outro, 
expressões de uma grande variabilidade, nos acordos construídos, na prática, em torno desse agente, acordos esses que se refletem, portanto, em especificidades importantes do perfil ocupacional. Portanto, embora bastante assemelhados, esse agentes, poder-seia dizer, serão sempre um tanto quanto diferentes, na dependência dos contextos e momentos históricos em que se inserem. A influência dessas condições será discutida com base no Referencial Teórico e retomada no capítulo de Discussão dos Resultados.

Quanto ao contexto histórico em que emergiram e à justificativa e objetivos apresentados, a SESP e a F.SESP, que o substituiu, teve sua origem em contexto de esforço de guerra, ligada, desse modo, a questões econômicas de manter ou assegurar a higidez da força de trabalho: trabalhadores e seus familiares. Com o passar do tempo, a F.SESP passou a responsabilizar-se pela prestação de serviços de saúde, aí incluídos os de saneamento básico a populações definidas, nos municípios onde estava instalada ou se instalou por solicitação de governos estaduais.

Já o PIASS, foi proposto como expressão de política pública, em contexto de regime de exceção, no bojo de medidas que visavam à manutenção da estrutura de poder dominante. As justificativas e os objetivos expressavam a preocupação com as populações marginais que viviam sob condições de extrema pobreza e o propósito de diminuir a marginalidade social e produtiva, em um primeiro momento, nos estados da região Nordeste.

Quanto ao Projeto DEVALE, caracterizava-se, evidentemente, como iniciativa de extensão de cobertura e de interiorização de ações de assistência à saúde e saneamento. Apesar de oriundos das mesmas raízes, o PIASS Nordeste e o do Vale do Ribeira diferenciaram-se, logo de início, em alguns pontos fundamentais, como se pode observar, em especial na expectativa de atribuições e de impacto das ações dos agentes. O PIASS era coordenado por um grupo de médicos e enfermeiros sanitaristas que destacavam na atuação do agente a promoção dos direitos sociais e da cidadania. $\mathrm{O}$ Departamento Regional de Saúde do Vale do Ribeira, ao qual o programa estava oficialmente ligado, na época, em 1981, não o assumiu como política do Estado e, pelo contrário, muitos foram os problemas que a equipe de Coordenação teve na implantação e desenvolvimento do Projeto.

O PACS do Ceará, em suas origens, é proposto no contexto de emergência social e econômica, de calamidade pública. A ênfase, no primeiro momento, era o programa "frentes de trabalho", como gerador de emprego e renda, como instrumento 
da política. Já na segunda fase de implantação do Programa, deslocaram para o Agente de Saúde a viabilização de uma política de extensão de cobertura e de interiorização das ações de saúde, que se assemelhava muito às desenvolvidas pelos auxiliares de saúde do PIASS Nordeste.

Inspirado na experiência do Ceará, do DEVALE e de muitos municípios brasileiros que implantaram propostas similares a partir da eleição direta para prefeitos, assumindo algumas de suas diretrizes básicas do Ceará, o PNACS posteriormente PACS - aparece em um contexto de redemocratização do País. O "Plano de Ação" do Governo Federal para o Ministério da Saúde, previa, entre outras metas, a contratação de 100 mil agentes comunitários de saúde. Um diálogo permanente entre a Coordenação Nacional e as Coordenações Estaduais do Programa, a definição de mecanismos de financiamento, os resultados obtidos nas regiões onde estava sendo instalado, garantiram os movimentos, as articulação e as ações técnicas necessários à consolidação da proposta. Mais uma vez, o sujeito da estratégia era o agente de saúde, selecionado na área onde iria trabalhar.

O PSF, por sua vez, embora lançado também como proposta do Ministério da Saúde, não representava uma substituição do PACS. Emergiu para responder a necessidades e articulações de determinados locais e teve uma expansão importante. Convive-se, hoje, no País, com os dois programas que foram propostos e justificados para a reversão, em regiões específicas, de condições adversas de saúde e de acesso a serviços e, como conseqüência, de seus reflexos, indicadores desfavoráveis de morbimortalidade.

Quanto ao sujeito de realização das propostas, a F.SESP não tinha o agente, mas o visitador sanitário, auxiliar que, ao lado do "atendimento de enfermagem" a crianças e gestantes sadios e outros grupos prioritários e atividades de "pós-consulta", na unidade, desenvolvia atividades em visitas domiciliares e na comunidade. $\mathrm{O}$ seu perfil, pode-se dizer, era diferente do agente de saúde. Em primeiro lugar, ele não era recrutado na população. As pessoas do município que se interessavam e possuíam o equivalente ao atual $2^{\circ}$ grau completo, inscreviam-se para a seleção que constava de prova e entrevista. Ele era o que se poderia chamar de agente institucional assumido. Não havia dúvidas quanto a isso e nem expectativa que ele desenvolvesse nenhuma mobilização popular, mas sim um trabalho de discussão com a população sobre como encaminhar e prevenir problemas de saúde. As suas ações incluíam a educação para a 
saúde, orientações, acompanhamento de crianças, gestantes e adultos, ações de prevenção e monitoramento de doenças, controle de parteiras leigas. Ele, como toda a unidade de saúde, tinha metas a cumprir - de vacinas, de gestantes, de crianças, de tuberculosos a serem detectados e atendidos. A sua referência era o enfermeiro, tanto para o treinamento, quanto para a supervisão, e ele efetivamente realizava ações e procedimentos relacionados com a prática de enfermagem.

Ao contrário dos outros programas aqui descritos, a ênfase do trabalho da F.SESP, para os resultados a serem obtidos, não era no agente e sim na programação oferecida.

A viabilização da política de extensão de cobertura e de interiorização das ações de saúde e saneamento, no caso do PIASS, assentava-se na atuação de um sujeito, recrutado na própria comunidade onde iria atuar, o auxiliar de saúde. $\mathrm{O}$ trabalho desse sujeito, desenvolvido a partir de uma unidade básica de pequena estrutura, os minipostos rurais, deveria atingir toda a população da localidade, contando, para isso, com uma participação da população, participação essa, pelo que se deduz, de natureza bastante utilitarista. A estrutura de suas atividades envolvia um leque de ações, desde a prevenção de doenças transmissíveis, a educação para a saúde, ações de saneamento básico até o atendimento das nosologias mais freqüentes, na localidade. Esse atendimento implicava a realização de atividades e de procedimentos caracterizados como da área de enfermagem e, em muitos casos, o diagnóstico e o tratamento dessas patologias.

A principal diferença, conforme já se colocou, entre o PIASS DEVALE e os seus congêneres do Nordeste, referia-se ao rol de atividades definido para o sujeito no DEVALE denominado Agente de Saúde - encarregado de viabilização do Programa, por conseqüência, à expectativa do impacto de sua atuação. Pela análise, consegue-se identificar, no conjunto de ações propostas, dois componentes principais: um primeiro, que se podería considerar como mais estritamente técnico, relacionado ao atendimento aos indivíduos e famílias, a intervenção para promoção da saúde ou para o monitoramento de grupos ou problemas específicos; ao lado desse, um componente que parece ter uma importância fundamental na concepção do Programa: o componente que se identifica como político, não apenas de solidariedade à população, de discutir saúde no contexto geral de vida, mas no sentido de organização da comunidade, de transformação dessas condições. O agente como um elemento de 
transformação social e não apenas de reorientação da concepção e do modelo de atenção à saúde. Essa é uma dimensão importante e diferenciada da proposta do Projeto DEVALE em relação aos demais. Um reflexo muito importante disso é evidenciado na concepção do treinamento inicial, na metodologia, na definição e no desenvolvimento do conteúdo.

Os estudos indicam que, com raras exceções, os agentes de saúde do Vale do Ribeira, embora tenham assumido, com o tempo, um perfil, uma identidade mais institucional, mantiveram bastante intensa a solidariedade com a população, grupo de onde se originaram e pelo qual foram eleitos.

Com relação ao PACS do Ceará, identifica-se uma diferença entre os dois momentos - o da seca e o do Programa - em vários aspectos, desde o rol de ações, o treinamento e a supervisão, até o relacionamento com a população.

O PACS Nacional, desde o início, guardou muitas analogias, mas também algumas especificidades em relação a seu principal inspirador. Em primeiro lugar, a negociação, durante todo o processo, com as entidades da enfermagem. Como conseqüência, em um primeiro momento, o compromisso de que seriam formados em auxiliar de enfermagem comunitário. Uma segunda característica, também importante para a conformação da identidade profissional do Agente: a coordenação Nacional do PACS exigia, nas negociações com os Estados e os Municípios, que o supervisor/instrutor dos agentes fosse um enfermeiro e não profissional de nível superior, defendido pelo Ceará. Essa condição ocasionou uma verdadeira "caça a enfermeiros", por parte dos municípios e estados que se dispuseram a implantar o Programa. As repercussões dessa exigência para a inserção e valorização profissional do enfermeiro são, hoje, muito evidentes. Ainda hoje é mantida essa exigência do enfermeiro, pela coordenação do PACS, para treinamento e supervisão dos agentes. Entretanto, a iniciativa de formá-los em auxiliar de enfermagem comunitário foi reavaliada, até em função das realidades locais e não mais colocada no cenário de possibilidades.

Cabem, ao final dessa síntese, duas considerações, de ordem bem geral, acerca das atribuições do agente, da expectativa de impacto de suas ações e da sua relação com a comunidade de onde se originou. Quanto ao primeiro aspecto, ressalta-se a idéia de que o trabalho do agente, na maioria das propostas, ultrapassa as dimensões de um mero atendimento às necessidades, ou seja, trata-se do trabalho e de algo mais do que o 
trabalho; da saúde e do que transcende a saúde. Por outro lado, nesse trabalho, a identidade de profissão apresenta-se como muito tênue. Essas são déias que serão trabalhadas no desenvolver da Tese.

Por outro lado, aborda-se um pouco a sua relação com a instituição e com a comunidade, interações fundamentais para a conformação de sua identidade. Os primeiros agentes de saúde do Ceará, eles eram, talvez mais ou exclusivamente, da comunidade. Eles vinham das frentes de trabalho, eram pessoas quaisquer, não eram nem selecionadas, não lhes era exigido perfil, eram pessoas que vinham para trabalhar, não eram nem agentes da comunidade, eram parte dela; não a representavam, mas essa não era uma preocupação, porque eles eram muito mais representantes mesmo sem o saber, de uma maneira que é quase do senso comum; não tinham nenhuma questão ou preocupação de representatividade, de poder representar enquanto tal. Nesse sentido, ele era menos liderança, e mais comunidade desorganizada. Quando se consideram os outros agentes, através dos depoimentos, apesar de, em muitas propostas, a supervisão ocorrer numa freqüência insuficiente, identifica-se, com o tempo, uma predominância da sua referência à instituição.

Em síntese, ainda que se identifiquem aspectos comuns entre todos, cada contexto introduziu, certamente, diferenças importantes em cada um dos Projetos. A negociação local, o contexto, os outros sujeitos e a sua relação, consideram-se as condições mais importantes.

\subsubsection{O Projeto Qualidade Integral em Saúde - QUALIS/PSF - São Paulo Contexto e Antecedentes}

Na região da Grande São Paulo, desde o Plano Metropolitano de Saúde, da década de 70, foi proposta, para a Zona Leste da cidade, a instalação de uma rede hierarquizada de serviços de saúde, com a construção de unidades básicas e de hospitais de referência.

Nessa mesma região, no final dos anos 80, foi implantado o Programa de Consultórios de Médico de Família, mediante co-gestão entre a Secretaria de Estado de Saúde e a Casa de Saúde Santa Marcelina. Para o novo programa, a proposta de atuação seguia o modelo cubano, com o médico de família trabalhando com um auxiliar de enfermagem e residindo na área de abrangência. Foram abertos, inicialmente, 17 consultórios de família, na região; em 1995, eram apenas sete os consultórios. 
Cabe citar essa experiência pela influência que, certamente, teve e tem, na implantação e no desenvolvimento do QUALIS Santa Marcelina. Os consultórios remanescentes do Programa de Médicos de Família, as unidades básicas, foram aproveitados e a população já trazia uma experiência de participação, o que deu um tom, certamente, específico ao novo Programa assumido pela Casa de Saúde. Além disso, antigos médicos de família ocuparam, de imediato, funções de forrmuladores, coordenadores e viabilizadores da nova estratégia.

Em novembro de 1995, o Governo do Estado de São Paulo, assumia, em articulação com o Ministério da Saúde e em parceria com uma Organização Social, a Casa de Saúde Santa Marcelina, a implantação do PSF, em São Paulo, com o nome de Projeto QUALIS - QUALIS I. Foram essas as justificativas apresentadas na ocasião:

- .Existência de UBS pertencentes à rede da SES-SP nas quais não se havia efetivado a fixação de profissionais de saúde, dentro da política tradicional de recursos humanos, por vários anos;

- Existência de equipes treinadas e com experiência, disponíveis para contratação, possibilitando a viabilização do funcionamento das UBS em curto prazo;

- Expectativa das comunidades das áreas referidas no que concerne ao atendimento de suas necessidades básicas de saúde, com manifestações expressas através de vários abaixo-assinados e solicitações de reuniões com a SES-SP;

- Viabilidade e interesse de utilização das UBS como campo avançado para aperfeiçoamento Técnico Profissional de residentes de Clínica Médica, Pediátrica, Ginecologia, Medicina Geral e Comunitária, Internato Médico e Profissionais de Enfermagem sob supervisão do Centro de Estudos e Escola de Enfermagem da Casa de Saúde Santa Marcelina;

- A Casa de Saúde Santa Marcelina ser uma Instituição Filantrópica reconhecida por seus relevantes serviços prestados à comunidade da região;

- Alta demanda primária e secundária atendida nos ambulatórios e Pronto Socorro da Casa de Saúde Santa Marcelina;

- Experiência prévia entre a SES-SP com a Casa de Saúde Santa Marcelina, parceiros no "Projeto Médico de Família", implantado pela SES-SP em 1989;

- Interesse de reorganização e aumento de qualidade na prestação de serviços de saúde dos Núcleos III e V, da SES. 
O objetivo geral do Projeto era reorganizar o modelo assistencial, baseado na promoção, proteção, diagnóstico precoce, tratamento e recuperação da saúde, em conformidade com os princípios e diretrizes do Sistema Único de Saúde -SUS.

\section{Objetivos específicos:}

1 - Promover o conceito de saúde como um direito de cidadania e como qualidade de vida.

2 - Promover a família como núcleo básico da abordagem no atendimento à saúde da população num enfoque comunitário.

3 - Prevenir as doenças e identificar fatores de risco aos quais a população está exposta.

4 - Fornecer atenção integral, oportuna, contínua e de boa qualidade nas áreas básicas de saúde à população adstrita, seja no nível domiciliar, ambulatorial ou hospitalar.

5 - Atender a população adstrita, preferencialmente através de agendamento, obedecendo às normas dos programas de saúde existentes, preservando, a possibilidade de atendimentos eventuais e domiciliares.

6 - Buscar a humanização do atendimento e, através do inter-relacionamento da equipe com a comunidade, proporcionar maior satisfação do usuário.

7 - Racionalizar o acesso e o fluxo do sistema de saúde (do nível de atenção primária até os de maior complexidade).

8 - Estimular a extensão da cobertura e a melhoria da qualidade do atendimento no sistema de saúde.

9 - Garantir aos profissionais do PSF supervisão, educação continuada, cursos de capacitação e treinamentos para aprimoramento.

10 - Divulgar, fundamentalmente, junto à população envolvida, os dados produzidos pelos serviços, bem como informações sobre os fatores determinantes de doenças.

11 - Incentivar a organização da comunidade para o efetivo exercício do controle social.

Após pouco mais de um ano de funcionamento, com uma cobertura de apenas $1 \%$ da população do município, avaliou-se que o projeto QUALIS apresentava resultados extremamente positivos, ao lado de problemas que não deveriam ser reproduzidos quando da expansão do modelo para outras áreas da Capital. Entre esses problemas, avultam a descontinuidade da área abrangida e as insuficiências detectadas 
no funcionamento da retaguarda especializada, que afetavam os mecanismos de referência e contra-referência e a plena eficácia do modelo.

Foi com base nesses resultados e no conhecimento desses problemas que surgiu a proposta de expandir aquele projeto, agora denominado PROJETO QUALIS/PSF, para os subdistritos de Vila Nova Cachoeirinha, Parque São Lucas e Sapopemba. Nessas localidades existiam duas unidades de saúde reformadas ou construídas, ao lado de outras oito em funcionamento precário. Em outubro de 1997, amplia-se o Projeto QUALIS com a parceria com a Fundação Zerbini - QUALIS II, com a previsão de instalação de ambulatórios de especialidades e enlace com os hospitais mais próximos, o que asseguraria a retaguarda para aqueles casos que tivessem indicação de internação. Também os exames complementares - tanto laboratoriais como de imagens - estariam assegurados. Nem a Fundação Zerbini, nem os coordenadores do QUALIS II viveram o Programa de Médico de Família, o que se considera deverá expressar-se em especificidades quando da comparação da proposta e da realização dos dois projetos de QUALIS. Essa abordagem, entretanto, embora os dados disponíveis permitam o seu aprofundamento, foge aos limites definidos para este estudo.

Até final de 1998, foram implantadas, no QUALIS I, 40 equipes de Saúde da Família, atuando em 12 unidades e com um ambulatório de especialidades, tendo sido cadastradas 25.628 famílias, ou 102.783 pessoas. No QUALIS II, para o mesmo período, foram implantadas 35 equipes, sendo 22 na Zona Norte e 13 na Zona Sudeste, com dois ambulatórios de especialidades, atendimento em Saúde Bucal e Saúde Mental, uma Casa de Parto em Sapopemba, tendo sido cadastradas 32.129 famílias, ou 121.768 pessoas.

\section{Atribuições do agente comunitário de saúde do QUALIS/PSF:}

1 - atuar de acordo com as diretrizes e normas do PSF.

2 - integrar a equipe de saúde da família, participando de todas as atividades de diagnóstico, planejamento e avaliação das ações individuais e coletivas, visando a proteção e a promoção da saúde da comunidade.

3 - desenvolver ações educativas junto à população, priorizando os grupos de maior vulnerabilidade como gestantes, crianças menores de 5 anos, idosos, portadores de doenças crônicas, visando a conquista da saúde. 
4 - estimular junto com os demais membros da equipe a participação popular, no sentido de que a comunidade amplie a sua consciência sobre os problemas de saúde e seus determinantes, visando a sua superação.

5 - identificar situações de risco individual e coletivo, e desenvolver ações de vigilância com vistas à redução da morbi-mortalidade e ao controle das doenças.

6 - participar ativamente das ações de educação continuada e dos cursos de capacitação profissional visando o desenvolvimento do seu papel profissional e como agente de mudanças.

7 - acolher o usuário de forma humanizada, ouvindo seus problemas e solicitações, dando as respostas adequadas de acordo com sua competência.

8 - cadastrar as famílias de sua área de abrangência e atualizar periodicamente os dados sobre nascimentos, óbitos e doenças.

9 - registrar corretamente as ações desenvolvidas e as informações colhidas na comunidade.

10 - encaminhar doentes à unidade de saúde e realizar acompanhamento específico de acordo com a orientação da sua equipe de saúde.

11 - realizar visitas domiciliares sistematicamente às famílias cadastradas.

12 - notificar as doenças e participar das ações de vigilância epidemiológica e sanitária.

13 - estimular ações de saneamento e melhoria do meio ambiente na sua área de atuação.

14 - desenvolver ações básicas de saúde pertinentes à sua função tais como: incentivo ao aleitamento materno, acompanhamento de crescimento e desenvolvimento, verificação das carteiras de vacinação, orientação de gestantes e nutrizes, uso de sais de reidratação oral.

15 - atuar de forma integrada a outras instituições relacionadas à saúde da comunidade.

16 - não divulgar informações recebidas durante as visitas domiciliares a quaisquer pessoas que não pertençam à equipe de saúde.

17 - notificar imediatamente a equipe mudanças de endereço de família da área.

18 - executar toda e qualquer outra atividade incluída no campo de ação de sua função. 19 - notificar imediatamente a equipe, caso venha a transferir seu domicílio para outra área. 
Em síntese, vale destacar que o Projeto QUALIS emerge em um contexto geográfico e político específico, uma grande metrópole, São Paulo, caracterizada, de um lado, pela concentração de recursos materiais e humanos na área de saúde e, de outro, pela desigualdade social e de acesso a serviços. A cidade de São Paulo vivia, na ocasião, uma determinada conjuntura política em que a Prefeitura implantava um modelo de assistência à saúde dissociado do SUS. O convênio para o QUALIS foi feito, então, mediante convênio entre a Secretaria de Estado da Saúde e uma instituição filantrópica, privilegiando a Zona Leste, que já havia abrigado uma proposta alternativa de atenção básica à saúde, o Projeto Médico de Família, bem como tinha sido palco de uma série de movimentos populares, que se desdobraram na instalação de equipamentos sociais e no desenvolvimento de relações entre Estado e comunidade baseadas na participação popular.

Abre-se, assim, um verdadeiro mercado de trabalho para indivíduos residentes nas áreas de abrangência do Projeto. Até o fim de 1998, foram contratados 300 agentes comunitários de saúde. Eles foram incluídos em equipes de trabalho que contam com um médico, um enfermeiro, um a dois auxiliares de enfermagem, com proposta de atuação para a unidade básica, o domicílio e a comunidade. A equipe deveria fazer reuniões de supervisão, em que se discutissem casos e situações. Seu trabalho seria orientado pela vigilância à saúde: fazer as visitas mensais e controlar os grupos de maior risco. O preenchimento dos dados diários de produção e a contabilização mensal conformariam o seu ritmo de trabalho e o conteúdo básico das visitas. Nessas condições, no contato relativamente mais íntimo com os demais profissionais e com o trabalho assistencial da unidade, em comparação com experiências do tipo dos agentes do PIASS, foi sendo conformada a sua identidade. A sua relação com a população deveria estar pautada pela busca da humanização do atendimento; ao mesmo tempo, o agente comunitário de saúde teria como função incentivar a organização da comunidade com vistas ao controle social. 


\subsection{REFERÊNCIAS TEÓRICAS}

A escolha do referencial teórico para apoio a este trabalho foi orientada para a compreensão de aspectos relacionados à construção de identidades profissionais, em determinados momentos históricos e em sociedades concretas. Essa providência decorreu da premissa de que a identidade profissional não se constrói no abstrato, mas em contextos concretos, a partir de negociações entre o Estado, a Sociedade e suas representações legitimadas.

Para caracterizar o Agente Comunitário de Saúde do QUALIS/PSF, a sua identidade, e discutir as especificidades e analogias em relação ao perfil de Agentes de Saúde de propostas que, em determinados momentos históricos, foram implantadas no Brasil, lança-se mão da apresentação e discussão de Políticas de Saúde, do seu contexto de proposição e de realização, da conformação e organização dos respectivos modelos de atenção, de sua inserção nos Sistemas de Saúde e da expectativa de participação de pessoal auxiliar de saúde na realização dos objetivos dessas políticas. Também, no interior dessas propostas, identificam-se aspectos que conformam o perfil ocupacional / social do Agente de Saúde, enquanto inserido em contextos específicos.

Nesse sentido, também será bastante utilizado o referencial representado por teorias e conceitos relativos à construção de uma identidade ocupacional ou profissional, à apreensão das dimensões envolvidas, nessa construção.

Ao se falar em profissão, pensa-se no saber para a prática como categoria privilegiada e na participação de vários sujeitos na conformação do todo, ou seja, na divisão e na complementaridade.

A apreensão concreta das dimensões do desempenho do Agente, das ações e das interações que integram o seu desempenho e conformam o seu perfil, dar-se-á tendo por base modelos de organização da oferta de serviços.

Esses conceitos e as suas teorias compuseram o tecido de sustentação sobre o qual e por meio do qual desenvolveram-se a análise e as discussões sobre a identidade do Agente Comunitário de Saúde do QUALIS.

Uma abordagem, obrigatoriamente, suscitada pela discussão da identidade profissional, refere-se a aspectos envolvidos com o surgimento e a legitimação das profissões nas sociedades. 
Nas sociedades atuais, a existência de uma determinada organização profissional interfere muito na forma pela qual as equipes se organizam e dividem o seu trabalho. Assim, essa discussão do que é profissão é uma parte muito importante e vai estar sempre presente na análise da organização do trabalho do agente, não apenas pelo lado da fiscalização profissional, mas numa perspectiva da prática profissional, ou seja, das ações orientadas por determinado saber.

Com relação a esse aspecto específico, parte-se da premissa que, em sociedades mais estruturadas, caracterizadas por um sistema de saúde mais complexo, por uma organização profisssional estruturada, por um mercado de trabalho já regulamentado, a presença/inserção de um trabalhador de saúde, sem uma referendada qualificação profissional, obedece a determinados limites em termos de perfil, competências e organização tecnológica do trabalho.

No caso específico do agente de saúde, historicamente, como se viu, sempre ocorreu uma disputa em termos de jurisdição, de espaço de atuação com o pessoal de enfermagem, mesmo que o agente nunca tenha atuado sob essa jurisdição.

Assim, compreender a relação entre o agente comunitário de saúde e a organização da enfermagem no Brasil - questão que, conforme já se adiantou, emergiu desde a proposta do PNACS pelo Ministério da Saúde -, compreender a relação entre o agente de saúde e a missão/tarefa de cuidar são aspectos necessários e importantes para os objetivos deste trabalho. Uma preocupação será a diferenciação entre o “cuidar" e o "tratar", como se verá adiante.

Procurar-se-á caracterizar, para cada uma dessas abordagens e dimensões acima referidas, se existem tipologias identificáveis, quais são as combinações possíveis entre essas dimensões. Em outros termos, busca-se identificar quais as condições que favorecem a emergência de um determinado perfil ocupacional/profissional como o do Agente Comunitário de Saúde e do seu rol de competências/responsabilidades, seus limites e possibilidades de atuação, suas necessidades.

Tomando o pressuposto acima colocado numa perspectiva mais radical, poderse-ia imaginar que não é possível a existência do Agente Comunitário de Saúde, conforme sua formulação inicial (de competências, de prática) no Município de São Paulo, capital do maior Estado do país. Em contraposição, um outro ângulo de abordagem informa que há combinações possíveis entre essas características; que podem ser observadas diferentes situações em relação ao aparecimento de um 
determinado perfil ocupacional. Contudo, em última análise, assume-se que esses macro-condicionantes combinados, segundo contexto histórico e social, determinam as características, a feição e o perfil de trabalho desses agentes, seus limites e possibilidades.

Em decorrência, no desenvolvimento do presente trabalho, assume-se o pressuposto que, dadas as influências dos respectivos contextos e das organizações sociais correspondentes, dos atores envolvidos, dos conflitos, dadas essas variáveis, o Agente Comunitário de Saúde, conforme concebido e, hoje, exercendo uma prática no Projeto QUALIS, no município de São Paulo, em qualquer das dimensões que se considere, tem mais especificidades que similaridades em relação aos seus congêneres de Programas análogos que foram ou são implantados em outras regiões do país.

\section{Construindo identidades profissionais}

A atividade econômica, como eixo da organização da estrutura e da dinâmica das sociedades modernas, foi o centro das pesquisas e da teorização dos clássicos do pensamento sociológico: MARX, WEBER e DURKHEIM.

"El trabajo es, em primer término, un proceso entre la naturaleza y el hombre, proceso en que este realiza, regula e controla mediante su propia acción su intercambio de materias com la naturaleza. En este proceso, el hombre se enfrenta como un poder natural com la materia de la naturaleza(....) Y a la par que de ese modo actúa sobre la naturaleza exterior a él y la transforma, transforma su propia naturaleza, desarrollando las potencias que dormitan en él y sometiendo el juego de sus fuerzas a su propia disciplina" (MARX 1966, 130).

A teorização nacional sobre processo de trabalho em saúde em todas as suas dimensões e sobre os agentes desse trabalho é muito rica e tem, como ponto de partida, a década de 70, com os estudos inéditos e as construções teóricas, de DONNANGELO (1975; 1976), de MENDES-GONÇALVES (1979;1992;1994), de SCHRAIBER (1993; 1997), entre outros, os quais foram tomados como referências, a partir de necessidade da apreensão de determinadas dimensões do objeto deste estudo.

\section{Profissão, profissionais e profissionalismo}

\section{A regulamentação das profissões}


É impossível discutir conceitos como profissão e profissional, sem que se proceda a uma contextualização desses conceitos, sua evolução histórica, já que se afirma que são histórica e socialmente determinados (MACHADO 1992).

A defesa das profissões, segundo uma abordagem do seu papel na sociedade, é classicamente caracterizada em DURKHEIM. No prefácio da $2^{\mathrm{a}}$ edição de Da Divisão do Trabalho Social, ele apresenta a idéia de que à corporação profissional caberia a função de "garantir uma nova ordem moral na sociedade moderna, de importância para gerir conflitos e para a garantia da democracia” (DURKHEIM 1973, 307).

A importância das corporações era por ele justificada, principalmente, pela influência moral que tiveram, no decorrer da história, quando pessoas do mesmo ofício eram unidas por laços estreitos. Para DURKHEIM, no momento em que, em uma sociedade, indivíduos que têm idéias, interesses, sentimentos, ocupações em comum, nessa condição, é inevitável que eles se procurem, associem-se, e que a partir daí, se forme, pouco a pouco, um grupo restrito, com "fisionomia especial, no seio da sociedade geral", do qual emana uma autoridade moral que reproduz as condições sob as quais foi concebido. A sua argumentação é que a subordinação dos interesses particulares a um interesse mais geral é a origem de toda o arcabouço moral de uma sociedade.

Além da sociedade, segundo o autor, também os indivíduos beneficiam-se quando esses grupos profissionais se formam; se a vida associativa é limitante para o indivíduo, de um lado, por outro, ela é fonte de segurança, de alegrias, de prazer, de segurança por comungar um mesmo conjunto de regras.

Lembra ainda DURKHEIM que a corporação, ao nascer, substituiu a família no exercício de uma função que era primeiramente doméstica, de passar o ofício de pai para filho. Da mesma forma que a família foi o meio no seio do qual se elaboraram a moral e o direito domésticos, a corporação é o meio natural no seio do qual devem elaborar-se a moral e o direito profissionais (DURKHEIM 1973, 315).

Mais recente, tendo como ponto de partida discussões sobre a profissão médica, FREIDSON (citado por BONELLI 1998), fornece uma enorme contribuição à teorização sobre as profissões.

Durante muito tempo, segundo esse autor, o conceito de profissão foi aceito sem questionamento, merecendo pouca elaboração sistemática, até depois da Segunda Guerra Mundial, quando se expandiu a sociologia acadêmica nos Estados Unidos. 
Nesse particular, o surgimento de novas abordagens caracterizou os anos 60 como "um divisor de águas intelectual no estudo das profissões" (FREIDSON 1998).

FREIDSON identifica como um dos problemas para uma conceituação de profissões o fato de elas serem tratadas como um conceito genérico, em vez de um conceito histórico, mutável, com raízes específicas em sociedades concretas. Por essa razão, ele argumenta, não existe um forma única e invariável, historicamente, para definir profissão. Para criar um padrão que orientasse estudos comparativos, seria necessário partir de conceitos básicos de prática, dos meios pelos quais a prática profissional é organizada e controlada e das instituições necessárias para obter e manter essa organização (FREIDSON 1998).

Ele próprio define profissão como "uma ocupação que controla seu próprio trabalho, organizada por um conjunto especial de instituições sustentadas em parte por uma ideologia particular de experiência e utilidade". O termo profissionalismo, segundo o autor, refere-se a "aquela ideologia e àquele conjunto especial de instituições" (FREIDSON 1998, 33).

Para uma compreensão histórica, ele lembra que as universidades medievais, na Europa, fizeram proliferar as três primeiras profissões liberais: a medicina, a advocacia e o clero, "profissões de status", em contraposição às "profissões ocupacionais", mais recentes (ELLIOTT 1972 apud FREIDSON 1998). Na Europa, onde o Estado era mais atuante, tanto na organização do treinamento quanto do emprego, o status e a segurança eram conquistados através de uma educação de elite e a identidade básica era também assegurada pela educação e não pela ocupação (FREIDSON 1998). Em contraposição, as profissões anglo-americanas conquistaram "sua distinção e posição no mercado menos pelo prestígio das instituições em que foram educadas do que por seu treinamento e identidade como ocupações particulares organizadas corporativamente às quais são imputados conhecimento especializado, comportamento ético e importância para a sociedade e para as quais reclamam privilégios”. (FREIDSON 1998, 53). Até por essa história, o profissionalismo, segundo o autor, deveria ser denominado de "mal anglo-americano", e não é de se estranhar que a literatura teórica sobre as profissões seja quase exclusivamente angloamericana.

MACDONALD (1995) chama a atenção para, além do enfoque usual dado ao saber, ao conhecimento, como um questão central para a discussão de profissão, há a 
necessidade de uma aproximação com a discussão do trabalho. E aí cabe uma distinção importante entre a noção de prática e a noção de trabalho.

O conceito de prática está referenciado, sobretudo, ao uso do conhecimento, ao uso de um saber esotérico. Então, como o próprio nome indica, a prática é praticar um saber, em um determinado contexto (objeto, relações, sujeitos). Então, quando se fala em prática, pensa-se no saber, no agente desse saber e no uso desse saber. Uma das grandes contribuições de FREIDSON é, do interior da Sociologia das Profissões, lembrar que esse uso do saber é subordinado a um contexto - à estrutura de produção e a uma relação entre indivíduos.

Para FREIDSON, se o contexto é importante, o sujeito, detentor de um saber, segue, num certo sentido, com autonomia, digamos assim, com alguma possibilidade de interferir, de superar o contexto.

Já uma outra corrente de pensamento, à qual filiam-se DONNANGELO e MENDES-GONÇALVES, acredita numa maior influência do contexto, da estrutura, para proporcionar um "constrangimento" desse saber, no processo de trabalho. $\mathrm{Na}$ seqüência, SCHRAIBER e MERHY, entre outros, encontraram em seus estudos, de um lado, uma maior influência do contexto nesse constrangimento, porém, de outro, a criatividade das pessoas (SCHRAIBER 1997; MERHY 2000).

No caso do indivíduo não ser profissional, de não dispor de saber auferido por instituição reconhecida, é mais ainda condicionado pelo contexto onde se realiza o trabalho.

Outro aspecto importante para a caracterização de um profisssional, refere-se à autonomia de que ele dispõe no desenvolvimento do seu trabalho. Ainda com apoio em FREIDSON, a autonomia do profissional viria desse conhecimento esotérico, desse saber. Ele argumenta que, apesar do prestígio de uma profissão ser uma delegação dada pela sociedade, ou pela clientela, ou pelo Estado, o status das profissões viria da autonomia. A autonomia, segundo ele, implica a capacidade de um profissão controlar uma área do conhecimento, tendo o monopólio sobre o campo, sem depender de outras profissões para a sua prática. Por seu lado, o poder profissional expressar-se-ia pelo controle sobre a divisão do trabalho, pela autonomia para definir a dimensão tecnológica, os seus conteúdos e a avaliação técnica. Esses componentes seriam decisivos para a autonomia profissional, aspecto nuclear do poder profissional e, em síntese, para a definição de uma profissão. 
FREIDSON indica que a "autonomia vincula-se à organização social no campo da medicina", na medida em que introduz o problema da divisão de trabalho na área de saúde, que envolve controle, autoridade do saber, monopólio e poder profissional dos médicos, fatores que hierarquizam as demais ocupações do campo - e aqui, a diferença entre a medicina e as profissões paramédicas não está no número de anos de escolaridade ou no conteúdo ensinado na escola, mas no monopólio sobre uma área de conhecimento capaz de hierarquizar outras ocupações (BONELLI 1998).

SCHRAIBER (1993) identifica três faces, igualmente importantes, na conformação da autonomia do profissional: uma face, relacionada com o mercado, a autonomia no mercado; outra face, a autonomia na estrutura da organização concreta do trabalho; a terceira face referida é a autonomia técnica, da decisão clínica. Para SCHREIBER, essas (faces da) autonomias, com o tempo, distanciaram-se do médico; pelo menos, duas delas. A autonomia mercantil, de fato, foi retirada dos médicos com a constituição de empresas médicas privadas e com a implantação dos serviços públicos; a autonomia da organização do trabalho, com o planejamento e o gerenciamento da assistência médica está sendo tensionada, embora o médico ainda disponha de muito poder, nessa vertente. Já a autonomia técnica, essa está relativamente preservada. Mesmo com os protocolos de orientação do trabalho, como cada caso é único, o médico na sua prática, mantém uma certa autonomia na decisão clínica.

Para SCHRAIBER, na maior parte das vezes, quando se analisa o processo de trabalho, reconhece-se mais a autonomia técnica. Entretanto, ao se observar o processo de trabalho e localizá-lo em uma organização de programa, ou em uma organização de serviço, ou mesmo, no mercado de trabalho, nesse movimento, é possível identificar as duas outras faces da autonomia, atualmente, restringidas.

Retomando as colocações anteriores de FREIDSON, poder-se-ia dizer, ao analisar as afirmações acima, que, ao referir-se à autonomia, FREIDSON aborda a dimensão apreendida por SCHRAIBER, como referente à face técnica da autonomia.

A discussão sobre trabalho, sobre saber e sobre suas relações, traz à tona a categoria "saber operante", de MENDES-GONÇALVES, ou seja, o resultado do "constrangimento" do saber científico quando ele se transforma em um saber aplicado, instrumento de trabalho que recorta o objeto, apreende suas características e propõe intervenções (MENDES-GONÇALVES 1994). O conhecimento científico e o saber 
clínico, no caso do médico, ele adquire quando tem o diploma, mas o saber operante é o que ele exerce, quando no momento do trabalho. Essa categoria "saber operante" era, para o autor, uma categoria de passagem entre esses dois planos e o que permitia, portanto, entender a prática como parte de uma estrutura econômica de produção de necessidades, objetos e relações entre sujeitos, portanto, enquanto trabalho.

Quando se fala em profissão, ao que as pessoas costumam, essencialmente, dar destaque? A qual é o saber e a qual estrutura de regulação de uso desse saber, a que corporação corresponde, ao que o conjunto de agentes faz.

A esse propósito, MACHADO (1995) faz distinção entre o profissional, aquele que negocia com uma clientela específica e o quase profissional, aquele que não tem o que negociar, pois não dispõe de "um corpo específico de conhecimento" nem de um mercado de trabalho "inviolável", como ocorre com os profissionais, no caso, médicos, advogados, entre outros.

"Um profissional é alguém que recebe importantes recompensas de um grupo de referência, cuja filiação é limitada a pessoas que se submetem à educação formal especializada(conhecimento esotérico) e que aceitaram um código de condutas apropriadas, definido pelo grupo" WILSON (1989, 60),

WILENSKY (1970, apud MACHADO 1995) analisa a distinção entre profissão e ocupação, com base em duas características. A primeira é o caráter técnico da tarefa do profissional, pois ela se baseia no corpo de conhecimento sistemático adquirido através de um treinamento escolar. Parte-se do princípio de que esse conhecimento é transmitido por pares experientes e credenciados. A segunda é constituída das normas e regras profissionais, as quais o orientam na execução das tarefas. Desse modo, qualquer ocupação que pretenda ser profissão e exercer autoridade profissional, terá que encontrar uma base técnica para fazê-lo, reivindicar que tanto as técnicas como a jurisdição estejam de acordo com padrões de treinamento e convencer o público que seus serviços são perfeitamente confiáveis. Para esse autor, existe um processo de profissionalização das ocupações, o qual é integrado por uma seqüência de cinco passos:

1. o trabalho torna-se uma ocupação em tempo integral, decorrente de "necessidade social" em relação a determinado trabalho;

2. criam-se escolas de treinamento, ou seja, a transmissão do corpo esotérico de conhecimento é feita por pares experientes; 
3. é formada a associação profissional, definem-se os perfis profissionais, o que garante, ao grupo, uma identidade;

4. a profissão é regulamentada. Esse é um passo essencial para a atividade profissional, já que se define o "território profissional", assegurando, desse modo, "o monopólio de competência não só do saber, como da prática profissional”;

5. adota-se um código de ética. Estabelecem-se normas e regras profissionais, enquadrando-os, ao tempo em que são excluídos os não-profissionais .

Considera-se apropriada, na discussão da identidade do agente comunitário de saúde, a inclusão da categoria saber - qual é o saber que orienta a sua prática? - e, sobretudo, a idéia do "saber operante", na medida em que esses sujeitos não têm o saber operante definido. Essa situação alia-se ao fato de que esses trabalhadores tendem a almejar uma profissionalização, ou seja, estar em uma estrutura de trabalho legitimada.

O enfoque da Sociologia das Profissões, ao falar de prática e em uso do saber, dá destaque a quem o usa, o agente. Então, para o estudo do agente comunitário de saúde, esse quadro de referência é muito útil; estudar o personagem, o sujeito, o ator embora cada um desses termos represente um conceito diferente - possibilita a abordagem da dimensão do indivíduo que porta um saber específico e esotérico e que atua com esse saber, num contexto determinado.

O conceito de identidade remete à noção de uma construção que os atores envolvidos fazem de sua própria ação; nesse sentido, legitimam essa construção na sociedade, com base em um processo de regulação, um processo de exteriorização das normas de atuação. E mais que isso, a identidade é uma imagem construída, é uma percepção. Essa construção dá-se com base em elementos de suas expectativas, das suas motivações, da sua percepção do trabalho dos outros. Então, a identidade é construída com base em elementos da subjetividade dos atores envolvidos, mas também em elementos da objetividade de vida desses atores SARTRE (1987). Em outras palavras, se eles estão num contexto onde têm um saber técnico bem definido, isso também vai compor a definição de uma identidade; se eles estão em um contexto onde há regras em relação ao que eles podem e não podem fazer, regras de atuação, por exemplo, quantas vezes devem visitar as famílias por mês, que têm que fazer o cadastro... isso conforma a identidade. Isso porque eles passam a saber que eles são os cadastradores, que eles são os visitadores, os orientadores; esses são elementos da 
objetividade. A outra dimensão que conforma a identidade é a percepção subjetiva desses atores acerca do que eles estão vivendo e o que os outros propõem para ele, uma identidade prevista. Na verdade, nessa discussão da identidade do agente, é indispensável, pelas suas características, que se trabalhe com essas duas dimensões de construção, essas duas entradas: os elementos da subjetividade e os elementos da objetividade

MARSIGLIA aborda um outro ângulo da questão da relação entre profissão e saber: "quando uma profissão se desenvolve, tenta apropriar-se de uma área de conhecimento e obter o domínio de um conjunto de técnicas. Historicamente, algumas áreas do conhecimento foram apropriadas por algumas profissões mais antigas e quando novas profissões surgem para compartilhar o mesmo objeto de atuação, acabam por serem vistas como um conjunto de técnicas apenas. Técnicas com as quais os profissionais podem trabalhar e até ter um certo "monopólio" na sua execução; no entanto esse monopólio não chega a conferir grande autonomia ou maior poder aos que a exercem - o exercício dessas profissões apresenta-se como subordinado ao exercício das profissões dominantes” (MARSIGLIA 1991, 115).

Para MENDES-GONÇALVES, a autonomia, o "monopólio de definir o que é o objeto do trabalho também é uma coisa histórica em qualquer área de praxis humana. Não foi por revelação divina que se soube quais são os objetos de trabalho; o homem os recortou sempre, de diversos modos. Numa certa altura da história da humanidade aparece, há muito pouco tempo - um século e meio, dois - aparece um conjunto de agentes sociais que propõe um recorte clínico-biológico, luta por ele, luta com extremo brilhantismo e ganha um monopólio que não encontra paralelo. Uma autoridade que é indisputada de maneira paradigmática. Em termos de acabamento de uma corporação, ele é um exemplo, porque ele é a própria invenção disso. Quem fez a receita da corporação antes? Deduziu-se do médico, como deve ser uma profissão” (MENDES -GONÇALVES 1991, apud MARSIGLIA 1991, 120-1).

Segue argumentando que um dos problemas é a profissão médica ter sido tomada como uma espécie de estereótipo para quase todos os estudos de profissão, deles se inferindo o que caracteriza uma profissão. Faz parte desse sistema que ele tenha sido profissionalizado, por assim dizer, "subprofissionalizando" os outros profissionais. Por outro lado, continua, não se pode "repensar um pedaço qualquer de 
trabalho de saúde" ignorando os médicos (MENDES-GONÇALVES in MARSIGLIA 1991, 120-1).

Vem de FREIDSON (1998) a consideração de que é graças ao treinamento no conhecimento formal e ao credenciamento e regulamentação (GIRARDI 1995) que é garantido às profissões um acesso exclusivo às suas posições no mercado de trabalho. O poder e os privilégios profissionais são sustentados por esse controle rigoroso, e os lugares no mercado são estabelecidos e conservados em função de uma divisão interna entre os profissionais, que abrange: a) os praticantes, que divulgam a profissão e garantem uma clientela, tendo algum poder sobre ela e sobre o trabalho que fazem; b) os administradores, que condicionam como e onde os praticantes podem exercer poder sobre os clientes; c) os intelectuais, que produzem o conhecimento abstrato e formal, formando as bases para as regras organizacionais e para as decisões de trabalho dos praticantes individuais (BONELLI 1998, 25).

FREIDSON ainda enuncia algumas relações no que diz respeito a trabalho e ocupação. O trabalho tem como modo de organização a ocupação, que, na sua forma menos organizada, pode ser designada como emprego, e, na sua forma mais organizada, como profissão. Profissão é um método formal lógica e empiricamente possível de controlar a organização do trabalho, não sendo um método semelhante, por exemplo, ao controle administrativo por meio de uma burocracia racional-legal. Dessa forma, ele faz a relação entre ocupação, classe e organização, por um lado e, por outro lado, trabalho especializado ou profissional e conhecimento e especialização (BONELLI 1998).

FREIDSON (1998) discute o que ele chama de princípio ocupacional, em oposição ao princípio administrativo. Para ele, as formas futuras de organização e ação ocupacional "constituirão uma contraforça à extensão do princípio administrativo ao controle do trabalho profissional" e "sustentarão a tal ponto o crescimento contínuo do princípio ocupacional, que a sociedade pós-industrial será a sociedade profissional” (FREIDSON 1998, 111).

Para MACHADO et al. (1992), o termo emprego não está diretamente associado a pessoas e indivíduos, e sim a ocupações e postos de trabalho; o termo surgiu "com as preocupações do Estado, a partir dos anos trinta, em mapear aspectos especificos correlacionados à demanda global por força de trabalho. Ele representa um dos três termos que representam três enfoques apresentados pelos autores, sendo 
os outros o de recursos humanos - que, "apesar de abstrair as relações sociais e estar lastreado na teoria de sistemas, busca interpretar as formas de gerenciamento desse 'fator de produção' que é a capacidade de trabalho dos individuos”- e o de força de trabalho - que "busca descrever e interpretar as relações sociais que lastreiam os trabalhadores que se inserem nesse ramo de atividade específico (o de serviços de saúde) e encontra-se mais calcado na análise marxista, que parte dos indivíduos e de sua inserção social no processo de trabalho".

GIRARDI (1995) é um dos autores que têm contribuído intensamente para a compreensão da constituição e regulamentação das profissões. Ele considera a regulamentação institucional um aspecto importante no processo de constituição de uma profissão. Considera-se que a sua área de estudos tem muita relação com a discussão da identidade profissional do agente comunitário de saúde.

Segundo GIRARDI, existem inúmeras formas de reconhecimento e classificação de uma ocupação. Em primeiro lugar, numa linha divisória bastante genérica, considera o segmento com regulamentação formal e, de outro, e articulado com o primeiro, aponta um segmento "desregulamentado dos mercados de trabalho, composto por ocupações reguladas majoritariamente pelo automatismo das forças de mercado e pelas ocupações informalmente reguladas... As ocupações não regulamentadas formam um importante contingente da força de trabalho em saúde, variável em suas proporções, de acordo com o país, mas sempre considerável. Nesse segmento estão incluídos a maior parte dos trabalhadores ocupados em postos e posições de apoio administrativo e de serviços gerais, bem como um contingente variável do pessoal técnico de saúde empregado nas organizações formais no setor" (GIRARDI 1995, 35).

Para GIRARDI (1995), as formas de regulamentacão das profissões podem variar desde aquelas que implicam um reconhecimento institucional de certos privilégios materializado na forma de leis e regulamentos - até as formas de reconhecimento mais brandas, pelos usuários, através de mecanismos, muitas vezes informais, de credibilidade e interesse. Por outro lado, pode existir mais de uma forma de reconhecimento regular para uma determinada profissão e parece que a quantidade delas está quase sempre diretamente relacionada com o status, a autonomia e o poder econômico alcançado pela categoria. Assim, enquanto profissões tradicionais, como a medicina, possuem garantias de legislação referente ao exercício, à formação, às 
relações de trabalho - incluindo piso salarial e jornada de trabalho - outras se encontram ainda debatendo por uma regulamentação básica que justifique, de alguma forma, a delimitação de um campo de saber específico.

GIRARDI invoca ABBOTT (GIRARDI 1988), para quem o sistema de reconhecimento profissional é composto por instituições sociais e organizações localizadas no sistema legal, no sistema de opinião pública e no mundo cotidiano do trabalho.

Ainda é GIRARDI que considera o sistema de reconhecimento profissional geralmente ativado por necessidades e questões de diversas ordens: tecnológicas, organizacionais, culturais e "naturais". O aparecimento de novas tecnologias, o crescimento das organizações, novos fenômenos culturais e naturais, demandas sociais, enfim, a complexificação da sociedade, têm, de maneira geral, determinado a busca pela profissionalização, principalmente através da regulamentação dos campos de atuação dos profissionais. Ele cita, como exemplo, a epidemia da AIDS, que gerou fortes demandas no campo da hematologia e hemoterapia. Nesse contexto, coloca-se a discussão do agente de saúde.

Em relação às novas tecnologias, inclusive organizacionais, pode-se dizer que elas, ao inaugurar novos campos de saberes e de práticas revelam, para usar os termos de ABBOTT, "verdadeiras lacunas jurisdicionais que tendem a ser preenchidas ou pelas profissões já existentes ou por novas ocupações ou especialidades emergentes. Essas novas ocupações ou especialidades ou profissões geradas nesse processo acabam pressionando por privilégios de regulamentação” (ABBOTT 1988, apud GIRARDI 1995, 40). Enquanto o trabalho do especialista é determinado basicamente pelo desenvolvimento científico e tecnológico de um setor, o reconhecimento de uma especialidade profissional pressupõe uma série de arranjos institucionais de acomodação de conflitos e disputas distributivas intra e inter-profissionais. O ponto central do argumento é que, para além da determinação tecnológica, a existência de ocupações e especialidades regulamentadas revela a construção de uma política da diferença no mundo do trabalho, com seus momentos característicos de articulação, negociação e incorporação na esfera pública da diferença (WALZER 1992, apud GIRARDI 1995). Parece haver consenso sobre que o sucesso dos grupos ocupacionais interessados em estabelecer ou de não permitir a regulamentação pública de um campo de "negócios", depende da quantidade de recursos de que dispõem 
organizacional, política e economicamente e de sua capacidade de articulação, negociação e incorporação de suas demandas no interior dos mercados e do sistema político (GIRARDI 1995).

No Brasil, a partir dos anos 70 e, principalmente nos anos 80, desencadeou-se um movimento pela busca de regulamentação das profissões de nível técnico e elementar. $\mathrm{Na}$ maioria dos casos, os tipos de conquistas regulatórias alcançadas, limitadas praticamente à definição de currículos mínimos para certificação profissional, refletem as dificuldades dessas profissões no sentido de se profissionalizarem plenamente. "Pode-se supor que o "medo" da competição, da invasão de um mercado não muito orgânico ou forte, onde apenas uma minoria pode pagar por serviços profissionais, funcionam como limites mais ou menos naturais do crescimento e aprofundamento das demandas jurisdicionais dessas ocupações. Em sentido inverso, como forças propulsoras, atuam as políticas de diminuição de custos de saúde que incentivam o crescimento de profissionais de nível médio, bem como propostas de mudanças da forma de atenção em saúde, as quais utilizam-se do profissional de nível médio como principal solução para problemas de desigualdade do acesso aos serviços de saúde ou de atuação em outras frentes que têm a ver com a saúde" (GIRARDI 1995, 58).

Enfatizando a recomendação de necessidade de análise dos custos diretos e indiretos da regulamentação profissional, GIRARDI argumenta que essa posição não significa uma apologia à desregulação do exercício e da prática das profissões e especialidades profissionais. De fato, considera, a regulamentação profissional tem representado, sem dúvida, uma forma de proteção legítima para o público e para os trabalhadores. É difícil conceber o livre exercício de uma profissão como a medicina sem a proteção do público contra as diversas formas de "charlatanismo". Por outro lado, para os trabalhadores, especialmente para os segmentos da força de trabalho em desvantagem nos mercados de trabalho, a regulamentação profissional pode significar uma salvaguarda simultaneamente técnica e ética, na medida em que coíbe sua utilização em áreas para as quais não estão profissionalmente preparados.

Ainda para GIRARDI, “a manutenção de padrões de qualidade profissional e de proteção ao público, possibilitada pela regulamentação profissional em saúde, deve ser assim contrabalançada com os riscos de cartelização ou da formação de monopólios profissionais. Assim postos, seus custos e beneficios devem ser cotejados com os desideratos da política nacional de saúde, quer dizer, com os princípios ético- 
morais e sociais assignados ao setor, como por exemplo as normas de eqüidade $e$ justiça sociais" (GIRARDI 1995, 62).

\section{Discutindo e construindo identidades: a organização burocrática versus a organização profissional}

Em estudo sobre a burocracia, WILSON (1989) identifica os fatores que se refletem na prática profissional e influenciam posturas e comportamentos individuais: experiências de trabalho anteriores, o contato com definição de tarefas através de normas profissionais, a ideologia política e aspectos relacionados com a burocracia institucional. Para o autor, posturas e comportamento no desempenho das atividades não dependem apenas da maneira como é avaliada essa prática, mas também das recompensas e punições que advêm, não apenas de indivíduos em posição de autoridade, na organização, mas também de colegas, de entidades profissionais que têm o poder de aprovar ou reprovar.

Para WILSON, a maneira como a atividade é realizada só será significativamente determinada por posturas individuais (e ideologias) caso haja, na organização, regras pouco claras especificando como o trabalho deve ser realizado e, mais ainda, poucos incentivos em reforço a essas regras. Ou seja, as crenças pessoais dos membros de uma organização só têm um efeito significativo sobre o modo com são executadas as tarefas quando os papéis a serem desempenhados não estão claramente definidos em normas e quando quem desempenha tal papel é relativamente pouco recompensado pela própria organização ou, no caso de um profissional, pela respectiva corporação. Deduz-se também dessa afirmação que, quanto menos respaldo externo de um grupamento profissional forte tiver o trabalhador, maior facilidade ele terá para obedecer às normas das organizações e maior necessidade ele terá delas (WILSON 1989).

Ainda segundo WILSON, em muitas agências governamentais, há muitos que trabalham segundo regras fracamente definidas, e todos eles trazem, em grau variado, concepções e representações de como o seu serviço deve ser feito, fatores esses oriundos de experiências anteriores, de sua sensibilidade e padrões profissionais, da sua ideologia política e talvez das características da sua personalidade. E, quanto mais fracamente definidas as regras, mais forte é a influência dessas concepções. Já para as organizações que não dispõem de objetivos e regras muito claros que orientem o desenvolvimento das atividades, é grande a influência de experiências anteriores das 
pessoas na definição das tarefas; é a experiência anterior dos empregados que irá determinar o quê e como fazer.

Fundamentais também, para WILSON (1989), são as normas profissionais que as pessoas aprendem e as oportunidades de trabalho que essas profissões oferecem a elas - e, aqui, o autor passa a definir o profissional. Segundo ele, o que é distintivo para os membros de uma profissão - pelo menos no que diz respeito ao seu comportamento na organização - não é status, renda ou deferências que eles recebem (como parece crer o senso comum), e sim a fonte dessas recompensas.

A fidelidade profissional versus a fidelidade à burocracia é abordada pelo autor a partir do sistema de incentivos. Assim, segundo ele, em uma organização burocrática, profissionais são os empregados que recebem grande parte dos seus incentivos de grupos localizados fora da organização e, assim, seu comportamento profissional não será totalmente determinado pelos incentivos controlados pela agência. Já os burocratas são os empregados cujos incentivos ocupacionais provêm inteiramente da organização, e WILSON indica evidências de que a visão política dos burocratas tende a corresponder à sua filiação a determinada organização, muito mais que ao seu status social. Experiências prévias e normas profissionais - e as oportunidades de carreira resultantes - , para WILSON, influenciam o comportamento de funcionários de uma organização burocrática. Ideologias políticas também devem ter efeito, mas, segundo ele, não há evidências suficientes para afirmá-lo. Entretanto, experiência, profissionalismo, e ideologia, parecem ter maior influência quando as leis, regras e circunstâncias da organização não definem precisamente a tarefa do operador. Então, o definidor mesmo são as normas organizacionais.

Discutindo as questões referentes às culturas organizacionais, MARSIGLIA, com base em FISHER, argumenta que a cultura organizacional não é, na sua essência, apenas padrões culturais e poderes políticos estabelecidos. Nas instituições em geral, cita ela, "as autoridades que são consideradas legítimas, bem como os mitos e símbolos que fortalecem a coesão e definem os sistemas de poder e de comunicação, constituem o produto de um processo de aprendizado social ocorrido no bojo da luta empreendida pela organização para ocupar seu espaço no ambiente" (MARSIGLIA 1993). A identidade da organização e os valores proporcionam aos agentes institucionais um misto de sentimentos de segurança e de coesão. 
Para SCHEIN (apud MARSIGLIA, 1993), cultura organizacional é o conjunto de pressupostos, "paradigma cultural", que um grupo inventou, descobriu ou desenvolveu ao aprender como lidar com os problemas de adaptação externa e investigação interna e que funcionaram bem o suficiente para serem considerados válidos e ensinados a novos membros como a forma correta de perceber, pensar e sentir, em relação a esses problemas.

Já para FLEURY, é fundamental “a incorporação da dimensão política que é inerente à questão da cultura organizacional, sendo esta concebida como um conjunto de valores, de pressupostos básicos expressos em elementos simbólicos que, em sua capacidade de ordenar, atribuir significações, construir a identidade organizacional, tanto agem como elemento de comunicação e consenso, como ocultam e instrumentalizam as relações de dominação”... “A percepção de que se pertence ao grupo (a organização) é o principal elemento para a manutenção da cultura organizacional" (FLEURY apud MARSIGLIA 1993)

O poder das corporações nas instituições para MARSIGLIA (1993) é decorrente, de um lado, do saber técnico e, por outro, da tradição e da antigüidade. Existe, entretanto, um outro poder que corre em paralelo: o poder advindo de um saber administrativo, de domínio dos mecanismos burocráticos que, apesar de menos evidente do que aquele vinculado ao saber técnico, tende a ser mais disseminado e efetivo no interior da estrutura.

\section{A identidade no pertencer a um grupo}

Para discutir a identidade de um agente comunitário de saúde, a sua inclusão em um determinado grupo, em uma organização social, utilizam-se conceitos e teorias desenvolvidos por ELIAS \& SCOTSON (2000) sobre a sociologia das relações de poder, em uma comunidade. Em Os Estabelecidos e os Outsiders, com base em um estudo sobre uma pequena comunidade industrial da Inglaterra, ELIAS \& SCOTSON estudam a comunidade, os grupos e os vínculos que a integram e caracterizam, as relações de poder no seu interior.

Em inglês, establishment e established são termos usados para designar grupos e indivíduos que ocupam posições de prestígio e poder, a "minoria dos melhores" nos mundos sociais mais diversos (NEIBURG 2000). O establishment é constituído de grupos que se autopercebem e que são reconhecidos como a "boa sociedade", tendo uma identidade social construída a partir de uma combinação singular de tradição, 
autoridade e influência. Estabelecidos são indivíduos que fundam o seu poder no fato de serem um modelo moral para os outros.

O termo que completa a relação é outsider, que designa os não membros da "boa sociedade", os que estão fora desse grupo. Os outsiders representam um conjunto heterogêneo e difuso de pessoas unidas por laços sociais menos intensos.

A identidade social dos estabelecidos é a de um grupo; são nomeados como tal, possuem um substantivo abstrato que expressa essa condição e os define como coletivo; já os outsiders não constituem um grupo social e são designados sempre no plural.

A caracterização e a análise desenvolvidas pelos autores em relação ao binômio estabelecidos - outsiders evidencia, com propriedade, importantes elementos inerentes às relações de poder, de pertencimento a um grupo, como dimensão da vida social: superioridade social e moral, autopercepção e reconhecimento, inclusão e exclusão (idem, 8).

A descrição de uma comunidade de periferia urbana apresentada por ELIAS \& SCOTSON mostra "uma clara divisão entre um grupo estabelecido desde longa data, que encarnava os valores da tradição e da "boa sociedade", e grupo mais novo de residentes, cujos integrantes eram tratados, pelos primeiros, como outsiders. O grupo cerrava fileiras contra eles e os estigmatizava, de maneira geral, como pessoas de menor valor humano", associando-os com a anomia, como a delinqüência, a violência e a desintegração. Além disso, o grupo estabelecido considerava que faltava aos outsiders a virtude humana superior - carisma grupal distintivo - que o grupo dominante atribuía a si mesmo (ELIAS e SCOTSON 2000, 19).

$\mathrm{O}$ que induzia as pessoas que formavam o primeiro desses dois grupos a se colocarem como uma ordem melhor e superior de seres humanos, em Winston Parva, era a antigüidade da associação, com tudo o que ela implicava. Apenas ela estabelecia o grau de coesão grupal, a identificação coletiva e as normas comuns "capazes de induzir à euforia gratificante que acompanha a consciência de pertencer a um grupo de valor superior" (ELIAS e SCOTSON 2000, 21).

Naquela pequena comunidade, a superioridade de forças do grupo estabelecido baseava-se no alto grau de coesão de famílias que se conheciam havia duas ou três gerações, em contraste com os recém-chegados, que eram estranhos, não apenas para os antigos residentes, como também entre si. Era graças a seu maior potencial de 
coesão, assim como à ativação deste pelo controle social, que os antigos residentes conseguiam reservar, para as pessoas de seu tipo, os cargos importantes das organizações locais, como o conselho, a escola ou o clube, deles excluindo os moradores da outra área, aos quais, como grupo, faltava coesão (ELIAS e SCOTSON 2000, 22).O grupo de antigos residentes, estabelecera para si um estilo de vida comum e um conjunto de normas. A participação na superioridade de um grupo e em seu carisma grupal singular era, por assim dizer, a recompensa pela submissão às normas específicas do grupo.

No estudo, as diferenças de tradição cultural desempenhavam um papel menor, mas um dos fatores capazes de modificar o impacto da situação nos membros dos grupos outsiders era sua posse de uma tradição cultural própria.

Os membros de um grupo estabelecido incluem-se, mutuamente, dentro das fronteiras grupais ao dizer nós, enquanto, ao mesmo tempo, excluem outros seres humanos a quem percebem como pertencentes a outro grupo e a quem se referem coletivamente como eles (ELIAS e SCOTSON 2000, 38).

Os membros do grupo das "famílias antigas" ligavam-se entre si por laços de intimidade emocional, que incluíam antigas amizades e velhas aversões. Assim como as rivalidades de status associadas a eles, também esses vínculos emocionais eram de um tipo que só se desenvolve entre seres humanos que vivenciam juntos um processo grupal de certa duração. Por outro lado, a aprovação da opinião grupal, como já vimos, requer a obediência às normas grupais. A susceptibilidade desses indivíduos à pressão do "nós" (we-group) é particularmente grande.

O estudo do grupo estabelecido de Winston Parva mostrou, em pequena escala, como o autocontrole individual e a opinião grupal estão articulados entre si. A imagem do nós e o ideal do nós de uma pessoa fazem parte de sua auto-imagem e seu ideal do eu tanto quanto a imagem e o ideal do eu da pessoa singular a quem ela se refere como "eu".

Os conceitos apresentados pelos autores, como parte de uma teoria da figuração estabelecidos-outsiders, tais como carisma grupal e ideal do nós, podem contribuir para o estudo de importantes referências na conformação da identidade do agente comunitário de saúde, através de análise de sua relação com diferentes grupos, de sua inserção ou exclusão. 
No estudo desenvolvido em Winston Parva, ficou muito claro que as respostas recebidas nas entrevistas individuais, particularmente as que diziam respeito às configurações existentes dentro dos vários bairros e entre eles, não eram a expressão de idéias separadamente formadas. As respostas individuais eram parte integrante das crenças e atitudes comuns, mantidas por várias formas de pressão e controle sociais, e representavam variações individuais das crenças e atitudes padronizadas que circulavam nessas áreas e dentro do grupo de referência.

As pessoas estabelecem relações quando negociam, trabalham, rezam ou se divertem juntas, e essas relações podem ou não ser altamente especializadas e organizadas. Mas elas também estabelecem relações quando "moram juntas num mesmo lugar", quando constróem seus lares num mesmo local. As interdependências que se estabelecem entre elas como criadoras de lares, nos quais dormem, comem e criam suas famílias, são especificamente comunitárias. "Em essência, as comunidades são organizações de criadores de lares, são unidades residenciais como os bairros urbanos, os vilarejos, as aldeias, os conjuntos habitacionais ou os grupos de barracas de acampamento (ELIAS e SCOTSON 2000, 166).

Em Winston Parva, a coesão, a solidariedade, a uniformidade de normas e a autodisciplina ajudaram a manter o monopólio, o qual, por sua vez, contribuiu para reforçar essas características grupais da comunidade. Num ambiente relativamente estável, o código de conduta mais sofisticado e o maior grau de autocontrole costumam associar-se a um grau mais elevado de disciplina, circunspecção, previdência e coesão grupal. Isso oferece recompensas sob a forma de status e poder, para contrabalançar a frustração das limitações impostas e da relativa perda de espontaneidade. A adesão ao código comum funciona, para seus membros, como uma insígnia social. Para os autores no sentido sociológico, a antigüidade refere-se a relações sociais com propriedades específicas. Elas dão um sabor especial às inimizades e às amizades. Nascida de uma história comum cuja lembrança se mantém presente, tal coesão constitui outro elemento de peso na configuração de possibilidades de esse grupo afirmar e manter, durante um certo tempo, seu poder e status superiores aos dos demais (ELIAS e SCOTSON 200).

Para os autores, alguns dos problemas fundamentais surgidos do encontro entre os grupos estabelecidos e outsiders, em Winston Parva, não diferiram muito dos que podem ser observados em encontros similares em outros universos, ainda que, com 
freqüência, estes sejam estudados e conceituados sob rótulos diferentes. Muitas vezes parte-se do pressuposto de que as comunidades "estáveis" ou "imóveis" são o tipo normal e desejável de comunidade, ao passo que as que incorporam um alto grau de mobilidade social são anormais e não desejáveis. É quase invariável que as pessoas que mudam de uma classe para outra também se mudem de uma comunidade, um bairro ou um círculo social para outro; ao menos por algum tempo, elas parecem ficar no papel de recém-chegados e, muitas vezes, de outsiders às portas de um grupo já estabelecido.

A questão que parece estar sempre presente na cabeça das pessoas, nas discussões sobre a relação entre "indivíduo" e a "sociedade", não é uma questão de fato, mas de valores. Elas formulam e tentam responder perguntas como "o que veio primeiro, o que é mais importante, o indivíduo ou a sociedade?" (ELIAS e SCOTSON 2000, 183).

Uma outra referência muito oportuna, para apoiar a discussão da identidade do agente comunitário de saúde, é o documento elaborado por NOGUEIRA et al. (2000). Os autores identificam o agente como um genérico, de identidade comunitária, que realiza tarefas, não apenas do campo da saúde. A sua capacidade de liderança e a sua história de iniciativas de ajuda comunitária seriam partes integrantes e importantes do seu perfil. "Portanto, como requisito da política que lhe deu origem, o conjunto das atividades típicas dos ACSs tem de ser ancorado nesse perfil social. Devido a essas características, que valem para todos os contextos de desenvolvimento economico-social dos municípios, o ACS constitui um trabalhador sui generis."( NOGUEIRA et al. 2000)

No documento colocado para discussão, Nogueira argumenta que "o papel que o ACS exerce na relação com a comunidade tem que ser contemplado com prioridade na sua caracterização, que abrange dois aspectos fundamentais: a) identidade com a comunidade; e b) pendor para a ajuda solidária".

Nos debates acerca e em torno da figura do agente de saúde, na questão de identidade profissional, os autores identificam duas interpretações:

- "o ACS pertence ao grupo de enfermagem, em virtude de realizar cuidados de saúde para com as pessoas; e

- trata-se de um trabalhador genérico e foram do comum, não tendo similar entre as tradicionais ocupações e profissões de saúde". 
Em relação à vinculação institucional, consideram que "as alternativas de vinculação institucional têm que ser ajuizadas considerando igualmente o quanto elas podem facilitar ou dificultar o cumprimento pelo ACS do seu perfil social" (NOGUEIRA et al. 2000, 12).

\section{Modelos assistenciais em saúde - A relevância de organizar ofertas}

A atenção à saúde adquire diferentes configurações conforme os momentos históricos aos quais está articulada (ROSEN 1980; FOUCAULT 1981). Entendendo-se a prática em saúde como vinculada à estrutura social e de uma perspectiva histórica, há que se considerar a conexão entre a dimensão mais técnica da realização das ações e a dimensão social da mesma (MENDES-GONÇALVES 1986).

Definir necessidades de saúde é tarefa complexa. SCHRAIBER e MENDES GONÇALVES (1994) expõem essa questão de uma forma que, se considera, facilita a sua compreensão: de um lado, há indivíduos que procuram cuidados a partir de um carecimento, algo que ele entende que deve ser corrigido em seu estado social-vital atual, e para o qual ele acha que existem meios para uma solução (antevista). Pode ser uma alteração mais física, um sofrimento mental ou uma demanda por informação. $\mathrm{O}$ resultado das intervenções sobre o carecimento reconhece a necessidade e, portanto, torna as próprias ações necessidades, contribuindo para a reiteração da intervenção. Como toda intervenção só tem existência na sociedade como uma dada forma de prestação de assistência (produção, distribuição e articulação de serviços), há uma conexão íntima entre oferta e consumo de ações de saúde.

Tomando os saberes como instrumentos de organização técnica e social da assistência à saúde, destacam-se, de um lado, a clínica e, do outro, a epidemiologia (MENDES-GONÇALVES 1994), as quais fornecem, respectivamente, a referência ética e científica para a assistência médica individual e para as iniciativas no campo da saúde coletiva. Se a primeira representa um padrão relativamente homogêneo, diferenciado por graus de complexidade tecnológica, as práticas em saúde coletiva conformaram-se, historicamente, com diferentes objetivos e formas de organização das ações.

De forma sintética, pode-se caracterizar o modelo de atenção baseado no saber clínico como aquele que concebe a doença com ênfase na sua dimensão biológica, aplica meios para identificá-la no corpo do indivíduo e lança mão de recursos 
terapêuticos de incidência individual. Nesse modelo, a necessidade de saúde é, em geral, manifestada pelos indivíduos que buscam assistência, de forma a se livrarem de uma situação que gera dificuldades, no seu cotidiano. O cuidado é desenvolvido baseado, principalmente, no trabalho do profissional médico.

Também de forma sintética, no modelo de atenção baseado no saber epidemiológico, os problemas de saúde são concebidos como relacionados a condições ambientais e sociais. Para a sua apreensão, são aplicados métodos de identificação coletivos e para a intervenção, recursos que transcendem os indivíduos, estendendo-se ao meio e à organização da sociedade. Nesse último modelo, a necessidade de saúde é, em geral, estabelecida através de levantamento de dados em grupos populacionais e comparação dos dados com parâmetros considerados técnica e politicamente aceitáveis; a confrontação de um e outro alimenta o planejamento das ações e a avaliação dos resultados da intervenção. Os meios de atuação abrangem, além de medidas curativas, a prevenção e a promoção da saúde. O trabalho assistencial é desenvolvido necessariamente por um conjunto articulado de profissionais que possam dar conta da apreensão e do cuidado do problema, tomado em sua complexidade.

As práticas baseadas no saber clínico, conformado durante o século XIX (DALMASO 1991), representam o modelo dominante na formação dos profissionais universitários e de nível médio da área da saúde, e em termos de recursos financeiros investidos. Também, como forma de consumo de serviço de saúde e expectativa de cuidado pela população, é o padrão hegemônico. São exemplos de formas de organização de prestação de assistência baseados no saber clínico, o atendimento realizado em pronto-atendimento/atendimento eventual em unidade básica e em pronto-socorro, os serviços ambulatoriais especializados, além de toda a atuação em área hospitalar.

$\mathrm{Na}$ atenção primária à saúde, encontram-se ações baseadas em cada um dos saberes, mas, no conjunto, com hegemonia de um ou outro modelo de atenção, de acordo com a articulação entre as práticas em saúde e as demais práticas sociais. Para a identificação do modelo assistencial vigente em unidades básicas de saúde, MENDES GONÇALVES (1994) propôs a caracterização do processo de trabalho, em termos de conteúdos, finalidades, instrumentos e formas de realização e MEHRY (2000) e PEDUZZI (1998) destacaram a importância da ação e da interação dos sujeitos. 
Se o saber é instrumento básico para o trabalho, há uma série de outros elementos que conformam a prática, entre eles as características institucionais, o vínculo com a clientela, os meios de intervenção, as características individuais de profissionais e usuários. Destacam-se, aqui, ainda, dois aspectos de maior relevância para esse estudo, a relação entre trabalho e profissão e a constituição de identidade.

ABBOTT (1990) considera que está mais de acordo com a realidade pensar que é o trabalho empírico que conforma a teoria, em vez de considerar que o trabalho possa ser totalmente abarcado pelo saber. Portanto, para o entendimento das profissões, o ponto de partida, segundo esse autor, deveria ser o trabalho profissional, seus conteúdos, as formas de controle, a diferenciação em tipos de trabalho e a noção de área legitimada de atuação.

Se o trabalho do médico clínico é relativamente mais definido (também mais estudado), há uma questão básica na definição do objeto da saúde pública - o meio, o coletivo e um conceito positivo de saúde; e do objeto do trabalho na área de enfermagem - o cuidado. No caso dos Programas analisados, o objeto do trabalho do agente de saúde, a relação entre saúde e vida familiar e comunitária, coloca o desafio de apreender e lidar com relações afetivas e sociais.

A forma de organizar a assistência, de responder a determinadas necessidades de uma maneira ou de outra, cria não só ações, mas cria também ocupações e constrói identidades profissionais. Ao organizar o trabalho, definindo conteúdos e formas de agir, definem-se também as interações. Por exemplo, se é função do agente comunitário de saúde do QUALIS, “identificar situações de risco" e "desenvolver ações educativas", destacam-se, no seu perfil, a vigilância e a intervenção no estilo de vida dos indivíduos e famílias.

Tomando o sistema local de saúde como foco para reflexão, podem-se distinguir diferentes modelos assistenciais conforme uma particular articulação entre a dimensão técnica e a dimensão social do cuidado da saúde e da doença, de acordo com diferentes momentos históricos.

Identifica-se, por exemplo, na década de 1970 a implantação da chamada Programação em Saúde, nas unidades básicas da Secretaria de Estado da Saúde de São Paulo, caracterizada pela oferta organizada de ações de saúde (NEMES 1989). Esse modelo de atenção caracterizava-se, basicamente, por ter finalidade e objetivos gerais 
assentados em categorias coletivas; por ter programas definidos por grupos populacionais; pela utilização da equipe profissional; por operar a partir de atividades de rotina e eventuais; pela padronização de fluxogramas de atividades e de condutas terapêuticas principais; por ter um sistema de informações que permitia avaliações na própria unidade; e pela regionalização e hierarquização das unidades. O atendimento clínico aos indivíduos doentes estava previsto e subordinado à lógica epidemiológica. Na equipe prevista para a Programação, além do médico assistente e do enfermeiro com função mais gerencial do que de assistência direta, estava incluído o visitador sanitário, profissional responsável pelas ações de vigilância e orientação de medidas preventivas.

Segundo NEMES (1996), embora a Programação tenha alterado de forma substancial a organização dos trabalhos nos Centros de Saúde, não logrou, como havia sido proposto originalmente, modificar a prestação de serviços de saúde, mantendo-se, ainda no início da década de 80, a alocação privilegiada de recursos nos serviços de assistência médica individual e de vinculação privada conveniada. Simultaneamente, nos anos 80, vai ganhando força política no Brasil, o movimento que questionou profundamente o sistema de saúde e que resultou na formulação do Sistema Único de Saúde - SUS, implantado pela Constituição Brasileira de 1988, o qual propicia a universalização da atenção à saúde, gratuita e sob controle do Estado.

Nessa nova formulação, a rede de unidades básicas de saúde torna-se a principal porta de entrada no sistema de saúde, ampliando-se muito o volume de assistência médica individual na rede pública, organizada, principalmente, na forma de pronto-atendimento. Se ações de natureza coletiva, como a vigilância sanitária e a epidemiológica e o programa de imunização, foram mantidas como responsabilidade dos serviços públicos, o enfoque do trabalho da equipe de saúde deslocou-se para o atendimento de patologias clínicas ao qual se associava o controle de determinados grupos, com destaque para doenças cardiovasculares, como hipertensão arterial e diabetes.

Contemporâneo com essa hipertrofia da assistência clínica na atenção primária, ocorreu o enorme esforço de aumentar a qualificação dos profissionais de enfermagem, dando-se um prazo para que os antigos atendentes e visitadores fizessem o curso de auxiliar de enfermagem para poderem continuar prestando cuidados de saúde aos usuários. 
Vale mencionar dois movimentos mais recentes de reorganização da assistência à saúde, a descentralização, com as constituição de distritos sanitários (MENDES 1995), e o Programa de Saúde da Família, em suas diferentes modalidades regionais. Para além das suas nuances de conteúdo e forma, destacam-se seus referenciais de natureza epidemiológica: a base territorial e a adscrição da população, o planejamento e a programação local, a oferta organizada de ações (PAIM 1995), a perspectiva da intersetorialidade, o princípio da integralidade.

Considerando os objetivos deste estudo, ressalte-se o segundo movimento, o PSF, que inclui como seu instrumento privilegiado de atuação a vigilância à saúde, que se desdobra na visita mensal dos agentes a todas as famílias cadastradas e no acompanhamento, pela equipe, de grupos de risco. Para as doenças cardiovasculares, está previsto o diagnóstico individual do caso, o que implica mutirões para screening, e a mudança de comportamento dos indivíduos, levada a cabo através de atividades educativas, realizadas em grupo ou nos contatos individuais. $\mathrm{O}$ atendimento à demanda espontânea que, em um primeiro momento, em muitos locais de implantação do PSF foi secundarizada, gerou uma pressão de demanda e embate entre as expectativas da população e oferta de ações de saúde, deu origem, em um segundo momento, à instalação de atividade denominada de "acolhimento". O acolhimento denomina não só a atividade mas uma atitude que teria como objetivo propiciar a escuta da demanda e a busca de formas de resposta dentro e fora da unidade e do sistema de saúde. Portanto, o acolhimento integraria a demanda espontânea a atividades com características de oferta organizada (programática); no entanto, conforme a forma de se responder e reforçar a expectativa da clientela e de acordo com o modelo dominante de cuidado da saúde, corre-se o risco de reduzir o acolhimento a uma triagem para prontoatendimento médico ou de enfermagem.

A partir dos anos 80, pôde-se identificar mais um movimento de reorganização das práticas de saúde, não tanto de natureza técnico-administrativa, como podem ser caracterizadas as propostas dos distritos sanitários e de saúde da família (VASCONCELOS 1999), mas de concepção de saúde e das formas de atuação, com ênfase em "novas" estratégias de promoção da saúde (ROBERTSON e MINKLER 1994; GENTILE 1999). Tendo como marco a Carta de Ottawa, produzida ao final da Primeira Conferência Internacional de Promoção da Saúde de 1986, delineiam-se cinco campos de ação: políticas públicas saudáveis; ambientes favoráveis à saúde; ação 
comunitária; desenvolvimento de habilidades pessoais; e reorganização do sistema de saúde.

Neste movimento da promoção da saúde, o que está em questão é o reconhecimento de que a "Saúde", não está simplesmente relacionada à ausência de doenças ou ao tratamento de doenças, mas tem seu conteúdo ligado à qualidade de vida e ao bem estar das populações.

A vigilância à saúde permitiu uma ordenação e organização das ações no âmbito em particular nas atividades institucionais ligadas ao controle das doenças de notificação compulsória e reforçou a noção de que a educação é um fator tão importante quanto a assistência clínica, para a melhoria da saúde. No entanto, ela tem obtido pouca repercussão no tocante à incidência das doenças e aos aspectos de participação das comunidades.

Entre as atividades educativas, estão as orientações, como a restrição ao fumo, o controle do uso do álcool, a redução do peso acima do padrão considerado como normal e a diminuição da ingestão de gorduras saturadas e colesterol. Entretanto, BRESLOW (1999) chama a atenção para o fato de que, embora devam ser alcançadas, constituem-se em medidas tipicamente de prevenção para lidar com fatores de risco (de doença coronariana, câncer de pulmão e alcoolismo), não se caracterizando, propriamente, como medidas de promoção da saúde.

BUSS (2000) salienta que este tipo de enfoque mantém-se centrado apenas nas mudanças de comportamentos danosos dos indivíduos ou restritos a questões culturais de algumas comunidades. Considera que o conceito moderno de promoção da saúde deve implicar atividades voltadas tanto a grupos sociais como a indivíduos através de políticas públicas abrangentes (em relação ao ambiente físico, social, político, econômico e cultural) e do esforço comunitário, na busca de melhores condições de saúde.

Entre as formas de viabilizar a promoção da saúde, estão a ação intersetorial (integração de tipos diferentes de atuação) e o suporte social. Suas definições são como se seguem:

Ações intersetoriais: integração de esforços visando alcançar mais e melhores resultados e racionalizar recursos. Apesar da intersetorialidade ser uma estratégia presente de longa data, no discurso de operacionalização de políticas sociais, há freqüentemente dificuldades para colocá-la em prática. 
Suporte social: instrumento de trabalho na atenção básica à saúde visando à melhoria da qualidade de vida e ao domínio do grupo e do indivíduo, sobre as situações. Parte-se do suposto de que uma pessoa que detenha mais conhecimentos, mais habilidades e maior confiança em si, pode proteger sua saúde e viver melhor.

O suporte social representa um conjunto de ações que podem ser realizadas por diferentes tipos de pessoas: os membros da equipe de saúde, parentes, amigos, voluntários. Faz-se suporte, por exemplo, quando se fornece informação: com ela as pessoas e os grupos podem se proteger e se defender melhor; saber onde procurar ajuda para um problema; e aprender a se cuidar. Outro tipo de suporte é o apoio emocional: fazer companhia, conversar, aconselhar, encorajar, mostrar que se está do lado da pessoa ou do grupo nas suas decisões. Este tipo de suporte faz com que as pessoas e os grupos ganhem mais confiança, mais força e possam decidir e lutar pelo que desejam (conceito de empowerment). Um terceiro tipo de suporte é chamado de instrumental, significando fornecer recursos técnicos e/ou materiais para ajudar a pessoa e os grupos a se protegerem e cuidarem melhor, podendo ser o desenvolver habilidades pessoais ou fornecer recursos materiais para cuidado da saúde ou manutenção da qualidade de vida (como, por exemplo, renda mínima, cesta básica, material para construção, medicação).

Como já se colocou, o suporte pode ser leigo (parentes, amigos, voluntários) ou profissional. A vantagem do leigo é que, muitas vezes, quem faz o suporte está mais perto e conhece mais quem vai receber o apoio. Mas onde o suporte leigo não é suficiente, pode-se contar com o apoio profissional.

Um entendimento mais restrito é considerar o suporte como ação comunitária, a ser realizado mais no domicílio e na comunidade, do que na unidade de saúde. Uma outra forma de pensar, mais abrangente, é incluir o suporte social entre as ações básicas de saúde, realizadas em todos os espaços: na visita domiciliar, no contato com agrupamentos, locais de reunião, nos atendimentos individuais, nas atividades educativas. Quando o apoio é realizado por um membro da equipe de saúde, o serviço se coloca na rede de suporte social, entre as estruturas de ligação entre indivíduos ou grupos sociais. A definição de qual é o suporte necessário, não pode ser fruto de decisão apenas da equipe, mas da conversa dos profissionais com a população e as pessoas, definindo juntos os problemas a serem enfrentados e como fazer. Se a decisão é unilateral, corre-se o risco de o profissional pensar que está fazendo um apoio, e de 
quem o recebe considerar que o apoio é desnecessário ou que até atrapalha mais do que ajuda. Por isso, a conversa é elemento imprescindível da atuação, ou seja, é uma conversa interessada (SCHRAIBER 1997), uma tecnologia não material do trabalho.

Esse campo da promoção da saúde, com os seus instrumentos - a ação intersetorial e o suporte social — representa uma área nova de prática e de saber, envolvendo necessariamente identidades em construção.

Ainda como um último ponto aqui apresentado, estão diferentes concepções da ação em saúde. A corrente hegemônica na área da saúde entende que cuidar é tratar e, para tanto, prevê uma série de recursos materiais, humanos e formas de organização da assistência. Sabe-se, no entanto, que cuidar não é só corrigir distúrbios mas, também, promover o bem-estar. E, diferente do tratar que, em geral, reduz o doente a objeto-paciente, é ao indivíduo que cabe julgar suas necessidades na busca do bemestar. Portanto, para o cuidado, há necessidade de arranjos tecnológicos mais sensíveis às necessidades de saúde de indivíduos e coletividades (MERHY 2000).

AYRES (1995) considera que o momento assistencial, espaço relacional entre profissional de saúde e usuário, espaço de "trabalho vivo em ato", é propício para subverter o paroxismo "objetivador" das pessoas nas práticas de saúde. E não só das pessoas, mas da universalidade do conhecimento científico, cujos conceitos, necessariamente, distanciam-se das realidades, complexas e vivenciadas (CZERESNIA 1999).

Aliás, como o cuidado em saúde é sempre atividade prática (entendida como ação frente a outro visando certos resultados), que tem como referência a ciência e a técnica, exige também um saber prático. O cuidado é sempre um exercício, não podendo seu objetivo estar definido a priori, nem as formas como alcançá-lo, mas representando uma construção articulada de meios e fins (AYRES 2000).

Quando se concebe a ação em saúde mais como cuidado, estabelece-se uma parceria entre profissional e indivíduo, baseada na qual se definem as origens e significados do problema, e as formas adequadas de enfrentá-lo. Nesse caso, há que se reconhecer o paciente, o usuário ou a comunidade como um "outro" portador de necessidades e valores, e se contar, como instrumento básico para a atuação, a participação, o diálogo, a negociação.

Para o âmbito deste estudo, ter como referência os modelos assistenciais em saúde alimenta os métodos da pesquisa, fornecendo as categorias de análise dos 
conteúdos do trabalho dos agentes de saúde e das reuniões de equipe, além de orientar a interpretação dos relatos, por exemplo, de atividades desenvolvidas na comunidade, das dificuldades encontradas no trabalho, das sugestões dos agentes para conteúdo e forma de treinamento. Ainda, os modelos servem como parâmetro para análise de perspectivas do trabalho dos agentes e das equipes e, por extensão, de possíveis modalidades de programa de saúde da família. Um último ponto de interesse para esse estudo é a relação entre formas e conteúdos do trabalho e a construção de identidade do profissinal.

\subsection{A INVESTIGAÇÃO}

Conforme se colocou anteriormente, no começo dos anos 90, o Ministério da Saúde assumiu a implantação, em nível nacional, do PACS. A evolução dos PACSs e seus resultados, os processos nos locais onde foram implantados, o processo de acompanhamento, fizeram com que, em alguns locais, fossem introduzidas transformações. Esse processo evoluiu para a institucionalização, em meados da década de 90, do Programa de Saúde da Família - PSF. Nesse ínterim, outros PACs e PSFs foram implantados em vários municípios, com graus variados de êxito na implantação e nos resultados observados.

O PSF, na proposição e conformação atuais, aparece como fruto da combinação de dois programas incentivados e assumidos pelo Ministério da Saúde: o Programa de Saúde da Família e o Programa de Agentes Comunitários de Saúde (PACS).

A Constituição brasileira de 1998 contemplou a saúde como um direito social, cuja garantia é responsabilidade de cada um e de todos e, em especial, do Estado, assegurando duas condições básicas: políticas públicas - econômicas e sociais para a redução de riscos - e acesso a todos os brasileiros a serviços e ações de saúde (MS 1988).

Assim, a Carta Magna de 1988 e a legislação que a sucedeu abrem novas perspectivas para reforço e legitimação/legalização de novos modelos de organização da assistência que assegurem os princípio e diretrizes do Sistema Único de Saúde, entre os quais, a universalidade, a integralidade e a eqüidade.

Assim, aparecem alguns relatos mais otimistas, outros mais moderados, todos, entretanto, ressaltando os resultados positivos e as perspectivas do modelo, benefícios 
e possibilidades enquanto estratégia para cumprimento dos ditames constitucionais e para melhoria da saúde e da qualidade de vida.

Quando se consideram as diferentes propostas, consegue-se identificar que, na sua trajetória de implantação, nas diferentes regiões, em especial nos anos 90, a justificativa dos PSFs tem seguido 4 eixos principais de argumentação, eixos esses perseguidos em paralelo e cuja sustentação, em termos de lógica, referem-se a:

\section{a- ampliação do acesso;}

b - racionalidade - técnica e econômica, enfocando tanto a racionalização das atividades para o sistema e para o paciente, quanto os aspectos econômicos, de otimização de recursos, inclusive de custos para o paciente: fazer o melhor, de maneira menos dispendiosa, o que possibilita a ampliação do acesso às ações de saúde a um número maior de pessoas;

c - humanização do atendimento, em várias expressões e significados, entre os quais, a recuperação do vínculo na relação profissional de saúde/ paciente, família, comunidade;

d - integralidade do atendimento, em duas principais perspectivas, complementares e articuladas:

- uma, da abordagem integrada e integral do indivíduo, em sua dimensão de cidadão (bio-psico-social), de cidadão na família e da família na comunidade, o que implica, além de uma postura diferenciada de cada um dos agentes do trabalho, uma atuação articulada de equipe multiprofissional e de equipamentos e níveis de atenção;

- outra, tendo por base um conceito do processo saúde-doença, implica uma abordagem e a articulação multi-setorial para o êxito nas ações de promoção, proteção e recuperação da saúde dos indivíduos e da comunidade.

Nessas perspectivas, aparece, como referência privilegiada para a realização da proposta, a constituição/atuação de Equipes de Saúde da Família integradas, cada uma delas, por um médico, um enfermeiro, um auxiliar de enfermagem e 4 agentes comunitários de saúde, com responsabilidade por 800 a 1.000 famílias residentes em uma área geográfica determinada (MS 1997).

Uma função muito especial está reservada ao médico de família e ao agente comunitário de saúde para a viabilização do modelo e, por conseqüência, do resultado 
das intervenções, ao estar centrado no desenvolvimento de cuidados permanentes e preventivos e não na doença e no hospital (JATENE 1998).

Quando se consideram as zonas urbanas, a inserção desse tipo de Programa assume várias especificidades e características outras, ampliando as necessidades de análise e de abordagem, na medida em que se inserem em sistemas de saúde mais complexos, já estruturados, com uma história, uma lógica complexa, inclusive na relação público/privado, com motivações e interesses variados.

Na cidade de São Paulo, onde as iniciativas anteriores desembarcaram de forma muito tímida, e não sistematizadas, o novo modelo de PSF está sendo implantado, desde abril de 1996, com a denominação de Projeto Qualidade Integral em Saúde QUALIS - em três áreas do Município da Capital.

A articulação do Setor Público - Ministério da Saúde e Secretaria Estadual de Saúde - e a parceria com o setor privado - no caso, uma Organização Social, a Casa de Saúde Santa Marcelina - viabilizou o início do Projeto em São Paulo: a implantação do QUALIS I, em Itaquera, zona leste do Município, em abril de 1996. Atuam, no momento, para uma população de cerca de 120.000 pessoas, 34 equipes de saúde da família, na comunidade e em 12 unidades básicas de saúde, em trabalho articulado com um hospital, a Casa de Saúde Santa Marcelina, atendendo a 23.000 famílias cadastradas.

Após essa experiência inicial, a articulação da Secretaria de Saúde do Estado com o InCor/HC FMUSP e a parceria com a Fundação Zerbini viabilizaram a implantação do Projeto QUALIS II, a partir de novembro de 1997, na zona sudeste (Parque São Lucas e Sapopemba) e na zona norte (Vila Nova Cachoeirinha), que cobre, até o momento, cerca de 150.000 habitantes.

Esse tipo particular de modelo e o conhecimento de suas possibilidades de realização vem suscitando um crescente interesse de vários setores da sociedade, em geral e, em particular, para a área de formulação, de gestão e administração de políticas públicas.

Nesse trajeto de proposição, formulação e implantação dos PSFs, em geral e do QUALIS, em particular, muitas são as questões que emergem e que devem se constituir em objeto de reflexão e aprofundamento. Considera-se que a identidade do Agente Comunitário de Saúde é uma dessas questões. O debruçar sobre essas questões possibilitará o avanço do conhecimento em termos de formulação e viabilização de 
políticas públicas que promovam a redução de riscos de adoecer e morrer e a garantia do acesso de todos os brasileiros a serviços de saúde, levando, em última análise, a uma melhor qualidade de vida.

Para este trabalho de pesquisa, parte-se da premissa de que é necessário conhecer o perfil ocupacional/social do Agente Comunitário de Saúde que atua no Projeto QUALIS. Conhecê-lo significa identificar analítica e sinteticamente os elementos empíricos que estão nas ações, percepções, motivações, expectativas e interações desses atores e em suas relações, quer com a comunidade, quer com seus pares e demais membros da equipe. Com base nesse reconhecimento do perfil ocupacional/social, procede-se à comparação, no sentido de identificar especificidades e analogias em relação a outros agentes de Programas de Extensão de Cobertura. 


\section{OBJETIVOS}

\section{Objetivo Geral}

Contribuir para objetivar categorias de caracterização do Agente Comunitário de Saúde do Projeto QUALIS/ PSF implantado no município de São Paulo, tais que permitam qualificar, especificar e discutir seu perfil ocupacional/social vigente e contrastá-lo com outros agentes de saúde de propostas similares implantadas no país.

\section{Objetivos Específicos}

- Contextualizar, historicamente, a emergência, no Brasil, das propostas de organização da assistência à saúde que previam a participação do agente de saúde visando à compreensão dos fatores intervenientes no perfil ocupacional/social dos respectivos agentes de saúde.

- Definir a categoria "perfil ocupacional/social" como categoria síntese entre agir e interagir, e entre o desempenho e a identidade desse agente.

- Identificar as concepções e expectativas dos diferentes sujeitos sociais dessas propostas em relação ao perfil ocupacional/social do agente de saúde, nos diferentes espaços e momentos históricos.

- Caracterizar o Agente Comunitário de Saúde do projeto QUALIS - município de São Paulo, em termos de perfil ocupacional/social, em especial, no referente:

- aos critérios para seleção e propostas de treinamento e supervisão;

- às ações que desenvolve;

- a sua interação com a organização do trabalho institucional;

- a sua inserção na equipe, sua articulação com os outros profissionais;

- a sua inserção em atividades comunitárias;

- a sua forma de relacionamento com os indivíduos e famílias da sua micro-área;

- a sua concepção sobre a identidade do ser agente, sobre o trabalho desenvolvido e seu significado para a população.

- Analisar o perfil ocupacional/social do agente do QUALIS, em relação aos agentes de outras propostas implantadas no país, identificando os elementos de contraste e de afinidade quando da atuação em áreas metropolitanas e em áreas rurais. 
- Discutir as especificidades do perfil ocupacional/ social do agente comunitário de saúde em áreas metropolitanas, contribuindo, assim, para o entendimento das possibilidades e das demandas/necessidades desse trabalhador.

- Discutir aspectos relacionados com a conformação de uma identidade profissional, em áreas metropolitanas. 


\section{METODOLOGIA}

O desenvolvimento desta Tese privilegiou uma abordagem metodológica que possibilitasse a caracterização do Agente Comunitário de Saúde do QUALIS, em termos de ações e interações, para a identificação do seu perfil ocupacional e do que há de específico neste Agente em relação àqueles que atuaram ou atuam em propostas similares, em uma perspectiva histórica de construção de uma identidade/viabilidade profissional.

Uma vez selecionado o objeto de estudo, impunha-se buscar as formas de apreendê-lo, o que orientou o enfoque no contexto e em, pelo menos, dois níveis da realidade em que ele se objetivava empiricamente: nas características do próprio objeto e do processo de trabalho e nas representações dos agentes desse trabalho (MENDESGONÇALVES 1994), dos demais interessados pela intervenção, além das formas interativas apresentadas pelos agentes desse trabalho, no decorrer do trabalho em ato, captados nos seus depoimentos (PEDUZZI 1998).

Os diferentes agentes envolvidos dão os matizes ao trabalho estabelecido de forma geral para os coletivos de trabalhadores (DENIS e CHAMPAGNE 1997). Na medida em que cada um dos atores pode ter seus próprios objetivos em relação à intervenção e também à sua avaliação, torna-se necessário identificar as expectativas e os objetivos dos diferentes sujeitos sobre a intervenção e as interações, sejam eles gestores, financiadores, profissionais, ou usuários reais e potenciais dos serviços ofertados.

É bastante extensa, nos dias atuais, a literatura específica sobre abordagens, dimensões e métodos analíticos quantitativos e qualitativos, inclusive sobre a elaboração de instrumentos de coleta de dados (QUIVY e VAN CAMPENHOUDT 1998; MARCONI e LAKATOS 1988; FERREIRA e AMADO 1996; QUEIRÓZ 1991; CONTANDRIOPOULOS et al.1994; MINAYO 1994). As fontes e os mecanismos de coleta de dados para essa apreensão são também inúmeros e variados.

Uma abordagem bastante adequada e atualmente utilizada em pesquisa empírica de caráter qualitativo é a triangulação dos dados, cujo objetivo básico é abranger a máxima amplitude na descrição e compreensão do foco em estudo, por meio do cruzamento de múltiplos pontos de vista a partir de uma série de informantes e diferentes instrumentos de coleta de dados (PEDUZZI 1998). 
A triangulação de dados implica assumir que, numa abordagem qualitativa, a subjetividade do pesquisador e dos sujeitos participantes da pesquisa está presente, em todos os momentos. Assim, dada a subjetividade presente, quanto mais movimentos de aproximação com a realidade forem feitos, maior chance haverá de se apreender mais e melhor as dimensões do objeto de estudo, ou seja, busca-se, através de diferentes abordagens, de diferentes olhares, aumentar a acuidade, a visão, e por conseqüência, ampliar a possibilidade de conseguir uma compreensão, o mais próxima possível, das características reais do objeto estudado (MINAYO 1992; MILES e HUBERMAN 1995; PEDUZZI 1998; MAYS e POPE 2000).

Nessa perspectiva, além da análise da auto-percepção e do trabalho concreto desenvolvido pelos agentes do trabalho, a partir do próprio agente de saúde, foram consideradas necessárias e incluídas, neste estudo, opiniões e concepções dos demais sujeitos que, direta ou indiretamente, contribuem para a definição do perfil do agente comunitário de saúde do QUALIS e que são interessados na implantação e nos resultados da intervenção (SILVA et al. 1986; SOUZA 1996; CHIZZOTTI 1991; MARCONI e LAKATOS 1996; BARDIN 1977; BECKER 1994; HAGUETTE 1995).

\section{Cenário}

O estudo foi realizado em dois projetos oriundos de parceria do Estado com o setor privado em três regiões do município de São Paulo, onde o Projeto QUALIS está implantado, mediante o trabalho de equipes de saúde da família atuando nas Unidades Básicas de Saúde, nos domicílios e na comunidade:

- QUALIS Santa Marcelina, na Região de Itaquera - onde a articulação do setor público - Ministério da Saúde e Secretaria Estadual de Saúde - e a parceria com o setor privado - no caso, uma Organização Social, a Casa de Saúde Santa Marcelina - viabilizou o início do Projeto: a implantação do QUALIS, em abril de 1996, para uma população de cerca de 120.000 habitantes e

- QUALIS Fundação Zerbini, implantado nas regiões de Vila Nova Cachoeirinha e Parque São Lucas / Sapopemba, viabilizado mediante a articulação da Secretaria de Estado da Saúde com o InCor/HCFMUSP e a parceria com a Fundação Zerbini, cobrindo, até o momento da pesquisa, cerca de 150.000 habitantes.

$\mathrm{Na}$ época em que se desenvolveu o trabalho de campo, de março a maio de 1999, estavam implantadas, no QUALIS, São Paulo, 26 unidades básicas de saúde. O 
QUALIS Santa Marcelina dispunha, na zona leste, de 14 unidades e o QUALIS F. Zerbini, de 12 unidades, sendo 7 na Região Sudeste e 5 na Região Norte. (Figura 3.1)

Quanto à população atendida pelo QUALIS, optou-se por caracterizá-la utilizando a classificação dos distritos da capital, segundo padrões de SPOSATTI et al. (2000), intervalos de medida de exclusão e de inclusão social - variando de -1,00 a 1,00 -, elaborados a partir de 49 indicadores, desde os mais clássicos de mensuração de condições de saúde até variáveis outras de risco e de qualidade de vida.

Assim, apresentam-se aqui os distritos onde reside a população atendida pelo QUALIS e, em ordem de classificação, as notas que lhes foram atribuídas após a análise das condições de vida de seus moradores. Cabe indicar que a referência positiva é a nota de inclusão 1,00 identificada no distrito de Moema. Por outro lado, a referência negativa ou a nota de exclusão (Iex), $-1,00$, foi atribuída ao distrito de Lajeado, zona leste do município, justamente onde se encontra uma das unidades selecionadas para estudo desta Tese. 


\section{MUNICÍPIO dE SÃo PAULO}

\section{DIR- I CAPITAL \\ LOCALIZAÇÃO DAS UNIDADES DO QUALISIPSF}

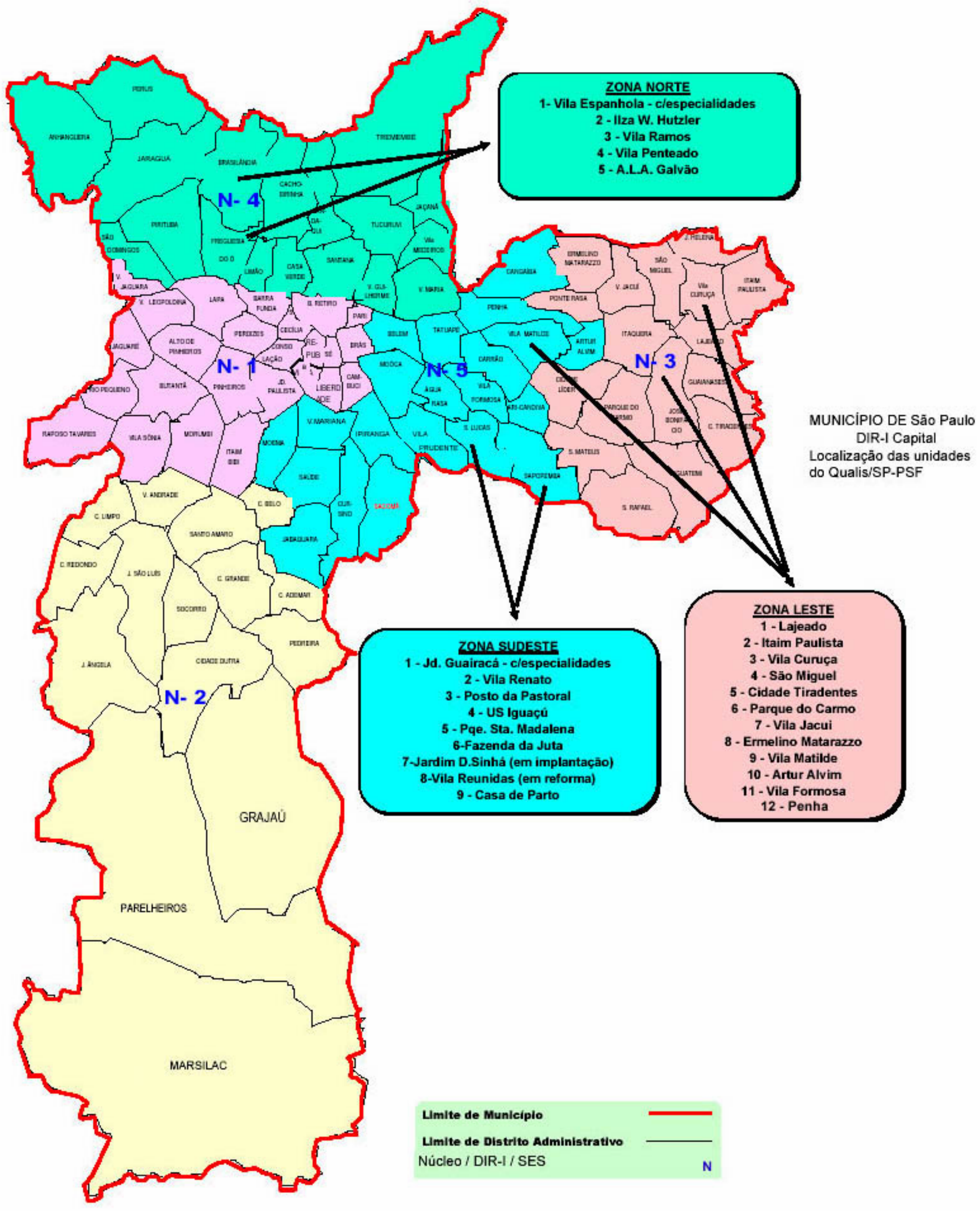


Quadro 3.1 Notas atribuídas aos distritos da zona leste de São Paulo de acordo com análise das condições de vida de seus moradores, 1995

\begin{tabular}{|c|c|c|c|c|c|c|}
\hline Posição & Distritos & $\begin{array}{l}\text { Iex } \\
\text { Autonomia }\end{array}$ & $\begin{array}{l}\text { Iex } \\
\text { Qualid. } \\
\text { De Vida }\end{array}$ & $\begin{array}{c}\text { Iex } \\
\text { Desenv. } \\
\text { Humano }\end{array}$ & $\begin{array}{c}\text { Iex } \\
\text { Eqüidade }\end{array}$ & IEX \\
\hline 1 & Lajeado & $-0,78$ & $-0,75$ & $-0,87$ & $-0,54$ & $\begin{array}{c}- \\
1,00\end{array}$ \\
\hline $2^{\circ}$ & Itaim Paulista & $-0,90$ & $-0,43$ & $-0,95$ & $-0,50$ & $\begin{array}{c}- \\
0,95\end{array}$ \\
\hline $7^{\circ}$ & Vila Curuçá & $-0,68$ & $-0,37$ & $-0,76$ & $-0,53$ & $\begin{array}{c}- \\
0,80\end{array}$ \\
\hline $14^{\circ}$ & São Miguel & $-0,52$ & $-0,35$ & $-0,54$ & $-0,65$ & $\begin{array}{c}- \\
0,71\end{array}$ \\
\hline $15^{\circ}$ & Cidade Tiradentes & $-0,68$ & $-0,25$ & $-0,71$ & $-0,41$ & $\begin{array}{c}- \\
0,70\end{array}$ \\
\hline $20^{\circ}$ & Parque do Carmo & $-0,55$ & $-0,37$ & $-0,57$ & $-0,35$ & $\begin{array}{c}- \\
0,63\end{array}$ \\
\hline $22^{\circ}$ & Vila Jacuí & $-0,62$ & $-0,19$ & $-0,55$ & $-0,42$ & $\begin{array}{c}- \\
0,60\end{array}$ \\
\hline $28^{\circ}$ & Ermelino Matarazzo & $-0,62$ & $-0,20$ & $-0,44$ & $-0,28$ & $\begin{array}{c}- \\
0,52\end{array}$ \\
\hline $41^{\circ}$ & Vila Matilde & $-0,49$ & $-0,04$ & $-0,10$ & $-0,43$ & $\begin{array}{c}- \\
0,36\end{array}$ \\
\hline $43^{\circ}$ & Artur Alvim & $-0,44$ & 0,20 & $-0,32$ & $-0,42$ & $\begin{array}{c}- \\
0,33\end{array}$ \\
\hline $46^{\circ}$ & Vila Formosa & $-0,38$ & $-0,10$ & 0,01 & $-0,44$ & $\begin{array}{c}- \\
0,31\end{array}$ \\
\hline $63^{\circ}$ & Penha & $-0,24$ & $-0,02$ & 0,39 & $-0,41$ & $\begin{array}{c}- \\
0,10\end{array}$ \\
\hline
\end{tabular}


Quadro 3.2 Notas atribuídas aos distritos da região sudeste de São Paulo de acordo com análise das condições de vida de seus moradores, 1995

\begin{tabular}{|l|l|c|c|c|c|c|}
\hline Posição & Distritos & $\begin{array}{c}\text { Iex } \\
\text { Autonomia }\end{array}$ & $\begin{array}{c}\text { Iex } \\
\text { Qualid. } \\
\text { de Vida }\end{array}$ & $\begin{array}{c}\text { Iex } \\
\text { Desenv. } \\
\text { Humano }\end{array}$ & $\begin{array}{c}\text { Iex } \\
\text { Eqüidade }\end{array}$ & IEX \\
\hline $25^{\circ}$ & Sapopemba & $-0,58$ & $-0,21$ & $-0,55$ & $-0,27$ & $-0,55$ \\
\hline $56^{\circ}$ & São Lucas & $-0,52$ & $-0,08$ & 0,31 & $-0,25$ & $-0,18$ \\
\hline
\end{tabular}

Quadro 3.3 Notas atribuídas aos distritos da região norte de São

Paulo de acordo com análise das condições de vida de seus moradores, 1995

\begin{tabular}{|l|l|c|c|c|c|c|}
\hline Posição & Distritos & $\begin{array}{c}\text { Iex } \\
\text { Autonomia }\end{array}$ & $\begin{array}{c}\text { Iex } \\
\text { Qualid. } \\
\text { de Vida }\end{array}$ & $\begin{array}{c}\text { Iex } \\
\text { Desenv. } \\
\text { Humano }\end{array}$ & $\begin{array}{c}\text { Iex } \\
\text { Eqüidade }\end{array}$ & IEX \\
\hline $6^{\circ}$ & Brasilândia & $-0,79$ & $-0,27$ & $-0,76$ & $-0,62$ & $-0,83$ \\
\hline $12^{\circ}$ & Vila N. Cachoeirinha & $-0,64$ & $-0,26$ & $-0,66$ & $-0,58$ & $-0,73$ \\
\hline $42^{\circ}$ & Freguesia do Ó & $-0,43$ & 0,05 & $-0,17$ & $-0,49$ & $-0,35$ \\
\hline
\end{tabular}

Fonte: Sposatti, A - Condições de Saúde e Qualidade de Vida na Cidade - In Anais VI Congresso Paulista de Saúde Pública, Águas de Lindóia, São Paulo. APSP, 2000.

Como pôde ser constatado, todos os distritos das regiões leste, sudeste e norte da cidade de São Paulo foram classificados por SPOSATTI (2000) com referência negativa ou nota de exclusão variando de $-0,10$ a $-1,00$.

\section{Fontes de Dados}


Procedeu-se ao levantamento de dados secundários e primários, de natureza qualitativa e quantitativa.

Em relação aos dados, cabe uma observação, a qual se aplica a todo o capítulo de Metodologia deste trabalho: a coleta de dados desenvolveu-se tendo como objetivo o projeto maior de avaliação da estratégia e de implantação do QUALIS. Considerando-se que este trabalho de Tese procede a um recorte do objeto maior da pesquisa, os dados foram utilizados e analisados conforme sua apropriação para a compreensão desse recorte específico.

- Documentos de referência sobre propostas de Programas de Extensão de Cobertura, de Programas de Agentes Comunitários de Saúde - PACSs - e Programas de Saúde da Família - PSFs - e sobre o QUALIS/PSF, implantado em São Paulo.

- Coleta de dados primários, a partir de:

- Entrevistas - gravadas em áudio - com os sujeitos que desempenharam, no passado, ou no momento da pesquisa, função importante em termos de decisão sobre a implantação do QUALIS. Assim, foram identificadas as categorias de:

a) formuladores ou policy makers;

b) gestores e coordenadores, os responsáveis pela formulação da implantação e pela implantação do QUALIS tal como é hoje;

c) dirigentes da Secretaria Estadual de Saúde de cuja decisão dependia o funcionamento do Projeto;

d) diretores das unidades básicas de saúde onde atuavam as equipes de saúde da família;

e) profissionais membros das equipes de saúde da família;

f) agentes comunitários de saúde;

g) outros profissionais das unidades:

- médicos especialistas

- dentistas

- técnicos de higiene dental

- atendentes de consultório dentário.

- Observação direta do trabalho desenvolvido pelos agentes comunitários de saúde (com registro em diário de campo); 
- Observação direta de reuniões da equipe da unidade de saúde da família e de reuniões de supervisão (com gravação em áudio);

- Observação direta de reuniões da equipe com a comunidade local (com gravação em áudio);

- Entrevistas - gravadas em áudio - com membros de organizações $e$ associações de moradores e ainda membros de Conselhos de Saúde.

\section{Trabalho de campo}

O preparo para o trabalho de campo foi realizado em sete fases:

- recrutamento, seleção e treinamento de entrevistadores e observadores (24 horas de treinamento, que incluiu simulações e dramatizações);

- elaboração dos instrumentos e roteiros de entrevistas e observações do trabalho dos agentes comunitários de saúde;

- entendimentos com financiadores, gestores e coordenadores dos Projetos QUALIS, tendo em vista a marcação de entrevistas;

- visita às três regiões onde estavam implantados os Projetos QUALIS;

- definição dos critérios

Durante reunião prévia com os Coordenadores Técnicos dos QUALIS e Coordenadores de Região do QUALIS Zerbini (na presença do Secretário de Estado da Saúde e de todos os pesquisadores do Projeto Novos Modelos de Assistência à Saúde), foram apresentados e aprovados os critérios, elaborados pelos pesquisadores, para a seleção das unidades de saúde onde se desenvolveriam as entrevistas com os profissionais e a observação do trabalho dos agentes de saúde, a saber:

a) características da população (sócio-econômicas, acesso a consumo de bens e serviços, inclusive saúde);

b) características da equipe em relação às características da população;

c) perfil das unidades (complexidade, origem - unidades do QUALIS / antigo

do Estado ou Prefeitura / de organização da comunidade, igreja etc.);

d) serviços disponíveis para a população; 
e) perfil dos dirigentes de unidade (se do QUALIS / se funcionário do Estado / outra situação);

f) tempo de funcionamento da unidade (início das atividades necessariamente até final de 1998);

g) número de famílias cadastradas

- a partir dos critérios estabelecidos, a indicação das unidades de saúde foi feita pelas coordenações regionais do QUALIS (leste, norte e sudeste), como aquelas que melhor representavam ou melhor atendiam as principais condições de operação do Programa de Saúde da Família. Foram selecionadas, pelos respectivos coordenadores técnicos, quatro unidades da região leste, três da região sudeste e três da região norte. As unidades indicadas foram:

- na região Sudeste: Jardim Guairacá (com 4 equipes de saúde da família), Vila Renato (com 3 equipes) e Unidade da Pastoral (com 2 equipes);

- na região Norte: Vila Espanhola (com 3 equipes), Hilza Hutzler (com 5 equipes) e Vila Penteado (com 5 equipes);

- na região Leste: Vila Guilhermina (com 3 equipes), Jardim Copa (com 3 equipes), Jardim Fanganielo (com 4 equipes) e Dom Angélico (com 3 equipes);

- contato com os diretores das 10 unidades de saúde indicadas para acerto de aspectos relativos ao trabalho. Nessa oportunidade, os diretores selecionaram, dentre as equipes de saúde da família existentes na unidade, aquela que mais se aproximava dos critérios pelos quais a unidade foi escolhida. Essa equipe selecionada seria, a partir daquele momento, a representante da unidade para todos os procedimentos de coleta de dados, ou seja, entrevista com todos os membros, observação do trabalho dos agentes e observação de reuniões.

\section{Instrumentos}

Os instrumentos utilizados na fase de coleta de dados foram:

a) entrevistas estruturadas, com base em roteiros (cf. MINAYO 1992, 109; FRIEDRICHS 1990, 207; SILVA et al. 1986). Os roteiros de entrevistas, para todos os grupos de profissionais, foram divididos em blocos temáticos, como explicitado, a 
seguir. O aprofundamento de cada bloco variou de acordo com a especificidade de cada grupo de entrevistados.

Bloco $A$ - Identificação (informações pessoais, incluindo um aprofundamento sócio-cultural, bem como a formação técnica e profissional em geral e específica para as atividades que exercia);

Bloco $B$ - Programa (definição do Programa na visão de cada um; atividade de cada um dentro do programa; grupos de relacionamento no âmbito do trabalho; função/importância do programa para a população);

Bloco $C$ - Prática (estabelecimento de contato com o Programa, treinamento)

Bloco $D$ - Atividades no cotidiano - sistema de informação e registro de atividades; organização do trabalho, principalmente no que diz respeito a decisões e conflitos; dimensões do trabalho, com identificação dos deslocamentos

a) do indivíduo para a família;

b) do serviço para a casa e arredores;

c) do poder técnico;

Bloco E - Sugestões, perspectivas

Os roteiros elaborados para coleta de dados empíricos, roteiro para entrevista e para observação do trabalho do Agente, foram testados com profissionais de unidades que não foram selecionadas para a pesquisa. Esse procedimento orientou o aperfeiçoamento tanto dos roteiros, quanto de aspectos do processo de coleta dos dados. Em anexo, apresenta-se modelo de roteiros elaborados para as entrevistas, no caso o roteiro para entrevista com os agentes comunitários de saúde. (Anexo 3.1)

Cabe referir que o Projeto de Pesquisa referente a esta Tese foi submetido à apreciação e aprovado pelo Comitê de Ética em Pesquisa da Faculdade de Saúde Pública - COEP, juntamente com os roteiros para as entrevistas e observação e o Termo de Consentimento (Anexo 3.2) elaborado para manifestação dos sujeitos que participariam da pesquisa.

O quadro abaixo, com a caracterização das entrevistas realizadas, possibilita uma idéia sobre a abrangência do estudo maior. Cabe novamente referir que os dados originários das entrevistas não foram utilizados em sua totalidade para a Tese, mas apenas nos aspectos que contribuíam para a aproximação do objeto e, por conseqüência, para o cumprimento dos objetivos. 
Vale ressaltar que, à época, apenas as unidades do QUALIS Zerbini ofereciam assistência odontológica e ambulatório de especialidades, o que ocasionou que apenas nas unidades das regiões Norte e Sudeste os profissionais responsáveis por essas modalidades de atendimento fossem entrevistados. 
Quadro 3.4 Caracterização das entrevistas realizadas para o Projeto "Novos Modelos de Assistência à Saúde: avaliação do Programa de Saúde da Família no Município de São Paulo"

\begin{tabular}{|l|r|r|}
\hline \multicolumn{1}{|c|}{$\begin{array}{c}\text { COLETA DE DADOS PRIMÁRIOS } \\
20 \text { de março a 31 de maio de 1999 }\end{array}$} & Previstas & Realizadas \\
\hline A. ENTREVISTAS & 08 & 08 \\
\hline a- Formuladores da Proposta & 11 & 11 \\
\hline b- Gestores, Coordenadores Técnicos do QUALIS & 10 & 10 \\
\hline c- Diretores da SES relacionados com o QUALIS & 10 & 10 \\
\hline d- Diretores de Unidades & 10 & 09 \\
\hline e- Médicos de Família & 10 & 10 \\
\hline f- Enfermeiros de Família & 14 & 14 \\
\hline g- Auxiliares de Enfermagem & 40 & 40 \\
\hline h- Agentes Comunitários de Saúde & 05 & 05 \\
\hline i- Dentistas & 05 & 05 \\
\hline j- Técnico de Higiene Dental & 05 & 05 \\
\hline k- Atendentes de Consultório Dentário & 12 & 12 \\
\hline l- Médicos Especialistas & 31 & 31 \\
\hline m- Membros da Comunidade & $\mathbf{1 7 1}$ & $\mathbf{1 7 0}$ \\
\hline TOTAL & & \\
\hline
\end{tabular}

O não cumprimento do plano de entrevistar todos os dez médicos de família das dez equipes selecionadas deveu-se a pedido de demissão do médico de uma das equipes, exatamente na semana anterior ao início dos trabalhos de campo.

B. observação documentada (estruturada através de roteiros) do trabalho dos agentes comunitários de saúde. A técnica utilizada foi a da observação sistematizada não participante, com anotação em diário de campo (cf. SILVA et al. 1986; MENDESGONÇALVES 1994). Esse método visou à coleta detalhada de dados e informações relativos às atividades e contatos cotidianos dos agentes de saúde no decorrer do 
trabalho, na unidade e fora dela. O observador deveria descrever, pormenorizadamente, as atividades, bem como sua duração, esforçando-se, ao mesmo tempo, para perturbar o menos possível o observado. O roteiro para observação, elaborado principalmente com base nas considerações de QUIVY e VAN CAMPENHOUDT (1998) e de SILVA et al.(1986), encontra-se em anexo (Anexo $3.3)$.

Com essa técnica, foi observado o trabalho realizado por cada um dos 38 agentes comunitários de saúde das 10 equipes selecionadas, durante uma semana, de $2^{\text {a }}$ a $6^{a}$ feira, durante 8 horas por dia, em todas as atividades. Assim, o agente foi acompanhado, pelo observador, no interior das unidades do QUALIS, nas ruas da área de abrangência dos projetos, nas atividades de grupo, junto às famílias, especialmente nas atividades de visitas domiciliares e por ocasião de atividades junto à comunidade.

As observações do trabalho dos agentes foram registradas em diário de campo, específico para cada um dos agentes.

C. Gravação e transcrição de 23 reuniões ocorridas nas unidades ou na comunidade, durante o tempo de observação do trabalho dos agentes.

\section{Plano de Análise dos dados}

A escolha das 10 unidades básicas de saúde para o desenvolvimento do projeto de pesquisa Novos Modelos de Assistência à Saúde: avaliação do Programa de Saúde da Família no Município de São Paulo e para esta Tese de compreensão de uma de suas dimensões, a caracterização do perfil do Agente Comunitário de Saúde, foi orientada por critérios que levaram em conta a diversidade do perfil das unidades em função de diferentes variáveis e as características da população, o que se pressupunha tivesse influência no dia-a-dia do trabalho do agente.

Procedeu-se à exploração do material empírico tendo em vista a identificação do perfil ocupacional do agente e das variações existentes, das características, nas várias dimensões que foram priorizadas e apresentadas como questões.

Para a descrição, a análise da prática e a caracterização do perfil do agente comunitário de saúde, foram utilizadas, como centrais, a observação do trabalho e as reuniões de equipes de saúde da família das quais participaram os agentes comunitários, gravadas durante o período de observação. Já os documentos, as entrevistas com os agentes de saúde e com os demais atores forneceram elementos 
para a apreensão de dimensões que permitiram construir o quadro de referência para a caracterização do perfil profissional do agente comunitário de saúde do QUALIS/PSF em São Paulo, e a discussão desse perfil em áreas metropolitanas.

\section{A análise da prática dos Agentes Comunitários de Saúde}

O trabalho sobre cada um dos recortes da Tese exigiu a utilização de quadros teóricos específicos para sustentação. Assim, considerando o Programa de Saúde da Família, Projeto QUALIS, como um programa assistencial integrado por eixos de ações, utilizou-se referencial do campo da organização de serviços (MENDESGONÇALVES 1994) para caracterizar as atuações desenvolvidas pelos agentes.

O olhar dirigido ao trabalho do Agente visou a identificar as várias dimensões e os vários eixos que o caracterizavam. Foi um "ir e vir" de olhares, de reflexões e de conclusões parciais sobre o objeto de estudo e com base no referencial teórico. Em outros termos, qual a natureza das ações que o agente desenvolve? E a responsabilidade? Resolve casos..., leva mensagem, leva informações...colhe apenas informações para a equipe...? E o modelo organizativo? O agente trabalha isolado, trabalha entre pares, trabalha numa equipe complexa? E a autonomia? Embora não haja hierarquia no discurso, há na prática?... Essas e outras questões fizeram parte do processo de elaboração dos instrumentos para descrição e para análise dos dados. Houve, então, um esforço de olhar o processo de trabalho do agente, internamente, procurando compreender as suas várias dimensões e interações.

Nesse sentido, procedeu-se, em primeiro lugar, a partir dos 38 diários de campo da observação do trabalho do agente, à elaboração de um rol de ações, ou seja, foi feito um check list, integrado por tudo o que estava registrado que o agente fez, durante a semana de observação.

O procedimento seguinte foi a descrição e análise de cada uma das ações desenvolvidas pelo agente. Trabalho análogo foi realizado em relação aos dados obtidos com a gravação das reuniões de equipe das quais os agentes participaram.

Assim, houve uma categorização da prática do agente de saúde em termos de conjuntos de ações de diferentes naturezas, correspondentes, em termos gerais, aos pólos de intervenção característicos do modelo de análise utilizado:

- ações de planejamento/ capacitação /supervisão 
- ações sanitárias e clínicas classificadas, por sua vez, em ações de vigilância à saúde e ações de assistência médica

- ações educativas

- ações comunicativas

- ações de assistência social

- ações intersetoriais

- ações comunitárias

- ações mistas

Após a caracterização da prática de cada um dos 38 agentes de saúde, a síntese posterior, por região, apontou para uma regularidade, um padrão, em termos gerais, homogêneo de prática dos agentes, ou seja, dos aspectos que conformariam a caracterização do seu desempenho, em cada uma das regiões - leste, norte e sudeste. A identificação dessa regularidade orientou, para esta Tese, duas decisões em termos de continuidade do tratamento dispensado ao material empírico. Em primeiro lugar, a decisão de aprofundar a análise dos aspectos relacionados com o desempenho e com o perfil ocupacional/social dos agentes do QUALIS, em duas unidades da região leste, uma da região norte e uma da região sudeste, ou seja, em quatro unidades, duas do QUALIS Santa Marcelina e duas do QUALIS vinculado à Fundação Zerbini. A segunda decisão foi a de analisar, em cada equipe, os diários observação de dois agentes de saúde, ao invés do universo (quatro ou cinco) disponível, por equipe.

A apresentação que se faz no corpo deste trabalho, a partir desse momento, refere-se a esse universo de dezessete agentes comunitário de Saúde.

As informações advindas da análise preliminar das entrevistas realizadas com os 40 agentes de saúde das 10 unidades visitadas, encontram-se no Anexo 3.4.

A quantificação a que se procedeu, dos tipos de ação e de interação, teve como objetivo uma comparação interna dessas tipologias e, assim, evidenciar o padrão dominante de desempenho dos agentes. Essa idéia deve orientar a leitura das informações constantes dos quadros apresentados.

Face a um padrão de trabalho identificado com base na análise dos dados obtidos com a observação direta do trabalho dos agentes e com a gravação das reuniões de equipe, aprofundou-se a caracterização e a compreensão desse padrão a 
partir da análise dos dados obtidos com os documentos e com as entrevistas realizadas com os diferentes sujeitos do Projeto.

Após caracterizar as ações dos Agentes em tipologias, segundo a natureza do resultado que elas produzem como ação técnica, a fase seguinte do trabalho consistiu na análise da perspectiva da interação, ou seja, da relação que o Agente promove - ou que resulta - no desenvolvimento do seu trabalho, tanto com os pares, com os demais profissionais da unidade, quanto com os indivíduos, as famílias e a comunidade. Esse processo resultou na caracterização do trabalho do agente em outras tipologias. Em outros termos, além dos diferentes tipos de ações, foram caracterizadas as diferentes modalidades e dimensões de interações que compõem as ações, ou que se conformam durante a sua realização.

A análise da interação do Agente no desenvolvimento do seu trabalho, envolveu o estudo dos vários componentes considerados como dimensões dessa relação:

- a responsabilidade / autonomia do Agente no desenvolvimento das ações

- a postura do agente face aos pólos político e técnico do Projeto QUALIS

- a articulação com outros agentes e com outros profissionais

- a inserção na estrutura da organização

- a sua articulação com a organização profíssional específica

- o seu relacionamento com a população

Após essa análise, os elementos encontrados já se constituíam em elementos classificatórios de padrões, não mais padrões de trabalho, mas padrões de desempenho do Agente, construídos com base no referencial teórico utilizado.

A fase seguinte correspondeu à articulação de todos os elementos obtidos, para a caracterização do desempenho do agente. O termo desempenho é aqui utilizado para indicar a caracterização do conjunto ações e interações no trabalho do Agente Comunitário de Saúde.

A seguir, a partir do desempenho caracterizado, analisaram-se as entrevistas realizadas com os sujeitos do Projeto. De um lado, a partir da análise das entrevistas com os formuladores, gestores, dirigentes das unidades, profissionais da equipe e membros da comunidade, foram criados conceitos nucleares que possibilitaram a caracterização de concepções/expectativas que os vários atores envolvidos detinham 
acerca da inserção e da prática dos agentes. Por seu lado, as entrevistas realizadas com os próprios agentes comunitários de saúde, após leitura e elaboração de um resumo sistematizado dirigido para pontos específicos, possibilitaram a identificação de um determinado padrão de expectativa/percepção/ posicionamento, sobre o seu trabalho. Nesse trabalho, foram criados conceitos de auto-percepção os quais ampliaram as possibilidades de compreensão das negociações envolvidas na definição do perfil ocupacional, dos limites e das analogias/especificidades dos agentes comunitários de saúde do Projeto QUALIS.

\section{Categorias de análise do perfil ocupacional - social dos Agentes Comunitários de Saúde}

Com base nos conceitos e teorias indicados, no material empírico e nas reflexões intermediadas, foram elaboradas categorias de análise do perfil do Agente Comunitário de Saúde do QUALIS, cujos padrões, aplicados aos desempenhos identificados, possibilitaram a discussão e a caracterização do perfil ocupacionalsocial do agente comunitário de saúde que atua no QUALIS, município de São Paulo.

A expressão perfil ocupacional -social é aqui utilizada para designar o resultado da combinação do desempenho do Agente com a sua caracterização social, as expectativas dos demais sujeitos e as representações de que é portador sobre o seu trabalho. Assim, é um conceito de síntese, embora analítico, que incorpora os resultados de todas as etapas anteriores de análise.

Agente Institucional e Agente de Comunidade foram as categorias de caracterização do perfil ocupacional-social do Agente Comunitário de Saúde do Projeto QUALIS.

O reconhecer essas categorias principais, nos inúmeros movimentos de aproximação com o objeto de estudo, não implicou a suposição de que essas tipologias pudessem ser identificadas na forma "pura" ou "ideal". Pelo contrário, esperava-se, na maioria das ocasiões, a coexistência de situações polares com perfis híbridos ou mistos, ou mesmo o deslocamento do perfil do agente de uma categoria para outra, na dependência do encaminhamento da situação concreta de trabalho.

$\mathrm{Na}$ seqüência, apresentam-se as figuras 3.2 e 3.3, que fazem uma síntese das etapas de análise utilizadas neste estudo. 
Figura 3.2 Síntese das etapas de análise para caracterização das ações e interações do Agente Comunitário de Saúde
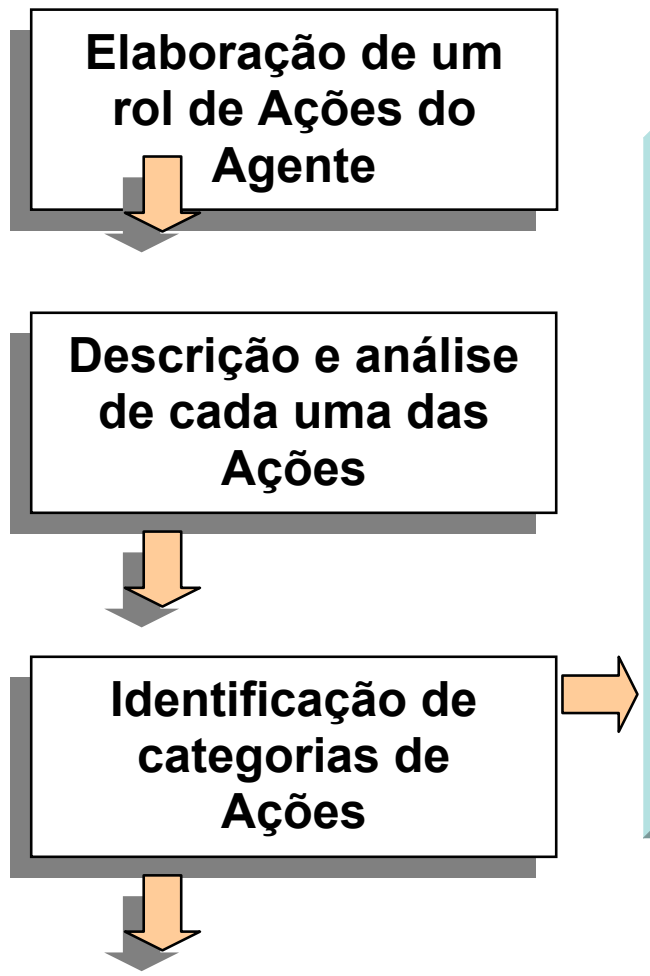

Análise da perspectiva da interação
.Ações de planejamento/ capacitação /supervisão

.Ações médico-sanitárias classificadas em:

Ações de vigilância à saúde

Ações de natureza clínica

.Ações educativas

.Ações comunicativas

.Ações de assistência social

.Ações intersetoriais

.Ações comunitárias

Ações mistas
- A responsabilidade / autonomia

- A postura do Agente face aos pólos político e técnico do Projeto QUALIS

- A articulação com outros Agentes e com outros profissionais

- A inserção na estrutura da organização

- A sua articulação com a organização profissional

- O seu relacionamento com a população 
Figura 3.3 Síntese das etapas de análise para caracterização do perfil ocupacional/social do Agente Comunitário de Saúde do QUALIS

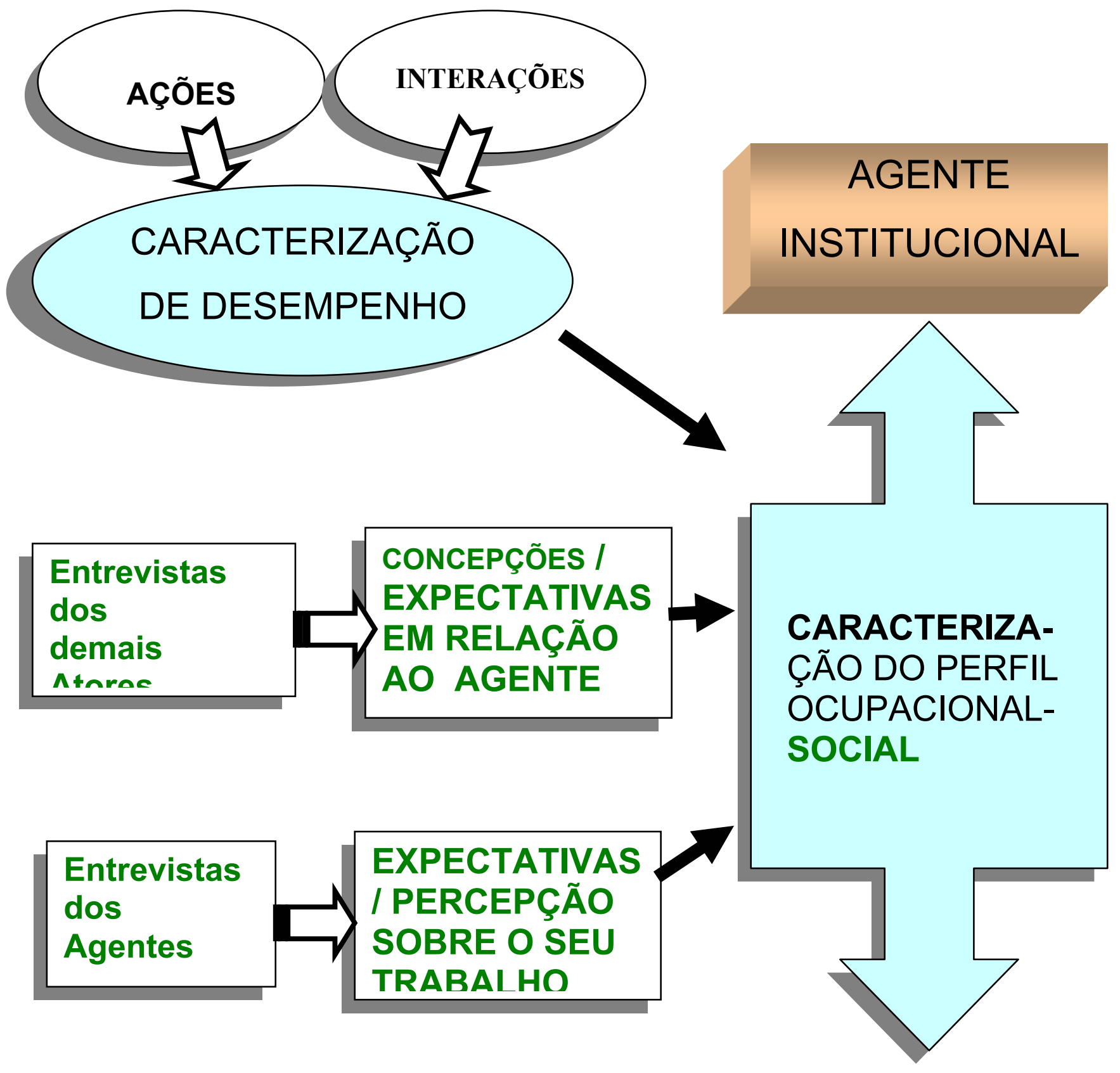

AGENTE de C.MMI INIIDARF 


\section{RESULTADOS}

\section{1 O AGENTE COMUNITÁRIO DE SAÚDE DO QUALIS}

\subsubsection{Caracterização}

As informações aqui tratadas tiveram como base as entrevistas realizadas com os Agentes Comunitários de Saúde das quatro equipes selecionadas do Projeto QUALIS.

Ressaltam-se as dificuldades que se verificam, em um estudo como o presente, de natureza qualitativa, de apresentar os resultados e, posteriormente, discuti-los. Assim, optou-se, no capítulo anterior, por uma apresentação comentada, e nesse, por uma síntese dos principais aspectos.

Apresenta-se, nos Quadros 4.1, 4.2, 4.3 e 4.4, a caracterização dos dezessete agentes de saúde segundo as variáveis sexo, idade, local de nascimento, escolaridade e situação atual de estudos, tempo de residência no bairro, tempo e tipo de trabalho comunitário, trabalho anterior, motivação para ser agente e tempo de trabalho na unidade.

Como pode ser constatado, há um amplo predomínio do sexo feminino, da faixa etária acima dos 30 anos, de escolaridade acima da exigida para o trabalho (saber ler e escrever). Apesar do longo tempo de residência no bairro, só uma parte dos agentes tinha participação mais direta e pessoal em atividade comunitária, a maior parte vinculada à Igreja Católica. Ser agente comunitário de saúde apareceu como oportunidade de re-ingresso no mercado de trabalho para muitos; um pequeno número refere que tornar-se agente representou uma etapa de profissionalização do trabalho já investido em atividades de visita a doentes e contato com a população, nesse caso representando um reconhecimento e remuneração de atividade antes voluntária. Grande parte dos agentes do QUALIS Santa Marcelina entrevistados havia sido contratada na implantação das Unidades de Saúde da Família, sendo poucos os com menos de 6 meses de vínculo. Quanto à situação de estudo atual, o curso de auxiliar de enfermagem foi referido por 3 dos 5 indivíduos que continuam a estudar, apontando para uma busca de profisssionalização no campo de atuação da enfermagem. 
Quadro 4.1 Caracterização de 4 agentes comunitários de saúde da Equipe 1 segundo sexo, idade, local de nascimento, escolaridade, estudo atual, tempo de residência no bairro, tipo de trabalho anterior, tipo de trabalho comunitário, motivação para ser agente de saúde e tempo de trabalho na unidade

\begin{tabular}{|c|c|c|c|c|}
\hline $\begin{array}{c}\text { CARACTERÍSTICAS } \\
\text { DO AGENTE }\end{array}$ & AGENTE 1 & AGENTE 2 & AGENTE 3 & AGENTE 4 \\
\hline Sexo & Feminino & Feminino & Feminino & Feminino \\
\hline Idade & 31anos & 42 anos & 58 anos & 24 anos \\
\hline $\begin{array}{l}\text { Local de } \\
\text { Nascimento }\end{array}$ & Pernambuco & Paraíba & $\begin{array}{l}\text { São Paulo } \\
\text { (interior) }\end{array}$ & $\begin{array}{l}\text { São Paulo } \\
\text { (capital) }\end{array}$ \\
\hline Escolaridade & $2^{\circ}$ grau & $1^{\circ}$ grau & $\begin{array}{c}1^{\mathrm{o}} \text { grau } \\
\text { incompleto } \\
\left(4^{\mathrm{a}} \text { série }\right)\end{array}$ & $1^{\circ}$ grau \\
\hline Estudo atual & $\begin{array}{l}\text { Auxiliar de } \\
\text { enfermagem }\end{array}$ & $2^{\circ}$ colegial & $\begin{array}{c}5^{\mathrm{a}} \text { série } \\
\text { (supletivo) }\end{array}$ & Não \\
\hline $\begin{array}{l}\text { Tempo de } \\
\text { residência no } \\
\text { bairro }\end{array}$ & 20 anos & 16 anos & 19 anos & 9 anos \\
\hline $\begin{array}{l}\text { Trabalho } \\
\text { comunitário }\end{array}$ & $\begin{array}{l}\text { Distribuição de } \\
\text { leite (entrega } \\
\text { tíquete na igreja } \\
\text { com a sogra) }\end{array}$ & $\begin{array}{c}\text { Antes de ser } \\
\text { Agente: igreja, } \\
\text { catequese de } \\
\text { adolescente e } \\
\text { visita nas casas } \\
\text { (semanal) }\end{array}$ & $\begin{array}{l}\text { Sociedade de } \\
\text { bairro - } \\
\text { reivindicaçã } \\
\text { o de água, } \\
\text { luz, asfalto }\end{array}$ & Não \\
\hline Trabalho anterior & $\begin{array}{c}\text { Caixa, } \\
\text { balconista, não } \\
\text { trabalhou } 10 \\
\text { anos, recepção } \\
\text { em hospital }\end{array}$ & $\begin{array}{c}\text { Caixa, trabalho } \\
\text { autônomo em } \\
\text { casa }\end{array}$ & Costureira & Costureira \\
\hline $\begin{array}{l}\text { Motivação para ser } \\
\text { agente de saúde }\end{array}$ & $\begin{array}{l}\text { Oportunidade } \\
\text { de emprego }\end{array}$ & $\begin{array}{c}\text { Aprofundar o } \\
\text { envolvimento } \\
\text { com a } \\
\text { comunidade, } \\
\text { oportunidade de } \\
\text { emprego }\end{array}$ & $\begin{array}{c}\text { Oportunidad } \\
\text { e de } \\
\text { emprego }\end{array}$ & $\begin{array}{l}\text { Serviço em } \\
\text { que não fica } \\
\text { trancada sem } \\
\text { ver o sol e } \\
\text { recebendo } \\
\text { ordem }\end{array}$ \\
\hline $\begin{array}{l}\text { Tempo de trabalho } \\
\text { na Unidade }\end{array}$ & Menos de 1 ano & 3 anos & 3 anos & 1 a 2 anos \\
\hline
\end{tabular}


Quadro 4.2 Caracterização de 4 agentes comunitários de saúde da Equipe 2 segundo sexo, idade, local de nascimento, escolaridade, estudo atual, tempo de residência no bairro, tipo de trabalho anterior, tipo de trabalho comunitário, motivação para ser agente e tempo de trabalho na unidade

\begin{tabular}{|c|c|c|c|c|}
\hline $\begin{array}{c}\text { CARACTERÍSTICAS } \\
\text { DO AGENTE }\end{array}$ & AGENTE 1 & AGENTE 2 & AGENTE 3 & AGENTE 4 \\
\hline Sexo & Feminino & Feminino & Feminino & Feminino \\
\hline Idade & 45 anos & 48 anos & 48 anos & 51 anos \\
\hline $\begin{array}{l}\text { Local de } \\
\text { Nascimento }\end{array}$ & $\begin{array}{l}\text { São Paulo } \\
\text { (capital) }\end{array}$ & $\begin{array}{l}\text { São Paulo } \\
\text { (capital) }\end{array}$ & $\begin{array}{l}\text { São Paulo } \\
\text { (capital) }\end{array}$ & $\begin{array}{l}\text { São Paulo } \\
\text { (interior) }\end{array}$ \\
\hline Escolaridade & $1^{\circ} \mathrm{grau}$ & $\begin{array}{c}2^{\circ} \text { grau } \\
\text { (contabilidade) }\end{array}$ & $2^{\circ}$ grau & $\begin{array}{c}2^{\circ} \text { grau } \\
\text { (incompleto) }\end{array}$ \\
\hline Estudo atual & $\begin{array}{l}\text { Sim (aux. de } \\
\text { enfermagem) }\end{array}$ & Não & $\begin{array}{l}\text { Sim (auxiliar } \\
\text { enfermagem) }\end{array}$ & Não \\
\hline $\begin{array}{l}\text { Tempo de } \\
\text { residência no } \\
\text { bairro }\end{array}$ & 27 anos & 48 anos & 12 anos & 45 anos \\
\hline $\begin{array}{l}\text { Trabalho } \\
\text { comunitário }\end{array}$ & Não & $\begin{array}{l}\text { Legião de } \\
\text { Maria, "visitas } \\
\text { p/ levar a } \\
\text { Palavra" }\end{array}$ & $\begin{array}{l}\text { Conhecia os } \\
\text { vizinhos } \\
\text { Ajudava nas } \\
\text { festas da } \\
\text { Sociedade de } \\
\text { Bairros (sogra } \\
\text { é secretária) } \\
\end{array}$ & $\begin{array}{c}\text { "Conhece } \\
\text { todo mundo } \\
\text { de } \\
\text { supermercado } \\
\text {, de rua..." }\end{array}$ \\
\hline Trabalho anterior & $\begin{array}{l}\text { Bordadeira } \\
\text { profissional }\end{array}$ & Dona de casa & $\begin{array}{l}\text { Atendente em } \\
\text { empresa } \\
\text { prestadora de } \\
\text { serviços } \\
\end{array}$ & $\begin{array}{l}\text { Costureira } \\
\text { autônoma } \\
\text { Agente dos } \\
\text { Correio }\end{array}$ \\
\hline $\begin{array}{l}\text { Motivação } p / \text { ser } \\
\text { agente de saúde }\end{array}$ & $\begin{array}{l}\text { Oportunidade } \\
\text { de emprego }\end{array}$ & $\begin{array}{c}\text { Visitar as } \\
\text { pessoas, } \\
\text { viabilizar horta } \\
\text { comunitária }\end{array}$ & $\begin{array}{l}\text { Oportunidade } \\
\text { de emprego }\end{array}$ & $\begin{array}{c}\text { Ajudar as } \\
\text { pessoas } \\
\text { dentro da sua } \\
\text { comunidade }\end{array}$ \\
\hline $\begin{array}{l}\text { Tempo de trabalho } \\
\text { na Unidade }\end{array}$ & $\begin{array}{c}\text { Cerca de } 3 \\
\text { anos }\end{array}$ & 3 anos & 12 meses & 3 anos \\
\hline
\end{tabular}


Quadro 4. 3 Caracterização de 5 agentes comunitários de saúde da Equipe 3 segundo sexo, idade, local de nascimento, escolaridade, estudo atual, tempo de residência no bairro, tipo de trabalho anterior, tipo de trabalho comunitário, motivação para ser agente e tempo de trabalho na unidade

\begin{tabular}{|c|c|c|c|c|c|}
\hline $\begin{array}{c}\text { CARACTERISTICAS } \\
\text { DO AGENTE }\end{array}$ & AGENTE1 & AGENTE 2 & $\begin{array}{c}\text { AGENTE } \\
\mathbf{3} \\
\end{array}$ & AGENTE 4 & AGENTE 5 \\
\hline Sexo & Feminino & Feminino & Feminino & Masculino & Masculino \\
\hline Idade & 35 anos & 24 anos & 40 anos & 33 anos & 20 anos \\
\hline Local de Nascimento & $\begin{array}{l}\text { São Paulo } \\
\text { (região } \\
\text { metropolitana) }\end{array}$ & $\begin{array}{ll}\text { São } & \text { Paulo } \\
\text { (interior) } & \end{array}$ & $\begin{array}{l}\text { São Paulo } \\
\text { (região } \\
\text { metropolita } \\
\text { na) }\end{array}$ & $\begin{array}{l}\text { São Paulo } \\
\text { (interior) }\end{array}$ & $\begin{array}{ll}\text { São } & \text { Paulo } \\
\text { (capital) } & \end{array}$ \\
\hline Escolaridade & $\begin{array}{ll}2^{\circ} & \text { grau } \\
\text { completo } & \end{array}$ & $\begin{array}{l}2^{\circ} \text { grau (técnico } \\
\text { contabilidade) }\end{array}$ & $7^{\circ}$ série & $\begin{array}{l}2^{\circ} \text { grau } \\
\text { (mecânico } \\
\text { Senac) }\end{array}$ & $\begin{array}{ll}2^{\circ} & \text { grau } \\
\text { completo } & \end{array}$ \\
\hline Estudo atual & Não & Não & Não & Não & Não \\
\hline $\begin{array}{l}\text { Tempo residência no } \\
\text { bairro }\end{array}$ & 29 anos & 16 anos & 9 anos & 20 anos & 14 anos \\
\hline Trabalho comunitário & $\begin{array}{lr}\text { Ajuda um e } \\
\text { outro no bairro: } \\
\text { ajuda muito um } \\
\text { dos vizinhos; } \\
\text { arruma roupa } \\
\text { para } r \text { quem } \\
\text { ganhou bebê; } \\
\text { ajuda na creche }\end{array}$ & 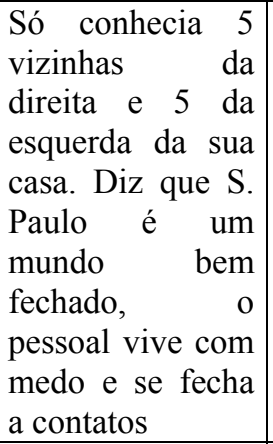 & Não & $\begin{array}{l}\text { Relação com } \\
\text { vizinhança }\end{array}$ & $\begin{array}{ll}\text { Participou } & \mathrm{de} \\
\text { reuniões } & \mathrm{da} \\
\text { comunidade } & \text { na } \\
\text { adolescência } & \end{array}$ \\
\hline Trabalho anterior & $\begin{array}{l}\text { Auxiliar de } \\
\text { vendas }\end{array}$ & $\begin{array}{l}\text { Contabilidade; } \\
\text { depois cuidava } \\
\text { do filho e da casa } \\
\text { por } 4 \text { anos }\end{array}$ & $\begin{array}{l}\text { Recepcionis } \\
\text { ta em } \\
\text { serviço } \\
\text { privado de } \\
\text { saúde }\end{array}$ & Metalúrgico & Carpinteiro \\
\hline $\begin{array}{l}\text { Motivação p/ ser agente } \\
\text { de saúde }\end{array}$ & Curiosidade & $\begin{array}{l}\text { Trabalho fora de } \\
\text { casa }\end{array}$ & \begin{tabular}{l}
\multicolumn{2}{l}{ Oportunida } \\
de de \\
emprego
\end{tabular} & $\begin{array}{l}\text { Oportunidade } \\
\text { de emprego }\end{array}$ & $\begin{array}{l}\text { Oportunidade } \\
\text { de emprego } \\
\text { (conhecia } \\
\text { atuação do } \\
\text { agente de saúde } \\
\text { quando morou } \\
\text { no Ceará) }\end{array}$ \\
\hline $\begin{array}{l}\text { Tempo de trabalho na } \\
\text { Unidade }\end{array}$ & $\begin{array}{l}\text { Início } \quad \mathrm{da} \\
\text { Unidade }(10 \mathrm{~m})\end{array}$ & $\begin{array}{l}\text { Início da } \\
\text { Unidade }(10 \mathrm{~m})\end{array}$ & 6 meses & & $\begin{array}{l}\text { Início da } \\
\text { Unidade }(10 \mathrm{~m})\end{array}$ \\
\hline
\end{tabular}


Quadro 4.4 Caracterização de 4 agentes comunitários de saúde da Equipe 4 segundo sexo, idade, local de nascimento, escolaridade, estudo atual, tempo de residência no bairro, tipo de trabalho anterior, tipo de trabalho comunitário, motivação para ser agente de saúde e tempo de trabalho na unidade

\begin{tabular}{|c|c|c|c|c|}
\hline $\begin{array}{l}\text { CARACTERÍSTICAS } \\
\text { DO AGENTE }\end{array}$ & AGENTE 1 & AGENTE 2 & AGENTE 3 & AGENTE 4 \\
\hline Sexo & Feminino & Feminino & Feminino & Feminino \\
\hline Idade & 56 anos & 41 anos & 34 anos & 29 anos \\
\hline Local de Nascimento & $\begin{array}{l}\text { São Paulo } \\
\text { (interior) }\end{array}$ & $\begin{array}{l}\text { São Paulo } \\
\text { (interior) }\end{array}$ & $\begin{array}{l}\text { São Paulo } \\
\text { (capital) }\end{array}$ & Ceará \\
\hline Escolaridade & $\begin{array}{c}\text { Sem } \\
\text { informação }\end{array}$ & $1^{\circ} \mathrm{grau}$ & $1^{\circ}$ grau & $\begin{array}{c}2^{\circ} \text { grau } \\
\text { (com curso } \\
\text { técnico de } \\
\text { administraç } \\
\text { ão) }\end{array}$ \\
\hline Estudo atual & Não & Não & Não & Não \\
\hline $\begin{array}{l}\text { Tempo de residência no } \\
\text { bairro }\end{array}$ & 29 anos & 32 anos & 32 anos & 6 anos \\
\hline Trabalho comunitário & $\begin{array}{c}\text { Pastoral da } \\
\text { saúde. Entrega } \\
\text { tíquete de } \\
\text { leite. } \\
\text { Catequese }\end{array}$ & $\begin{array}{c}\text { Voluntária } \\
\text { na } \\
\text { Igreja(farmá } \\
\text { cia } \\
\text { comunitária } \\
\text { e gestantes); } \\
\text { freqüenta } \\
\text { reuniões da } \\
\text { comunidade }\end{array}$ & $\begin{array}{c}\text { Aula sobre a } \\
\text { Bíblia para } \\
\text { crianças }\end{array}$ & $\begin{array}{c}\text { Igreja } \\
\text { (jovens e } \\
\text { crianças; } \\
\text { visita a } \\
\text { doentes; } \\
\text { novenas) }\end{array}$ \\
\hline Trabalho anterior & Costureira & Do lar & $\begin{array}{l}\text { Assistente de } \\
\text { telemarketing }\end{array}$ & $\begin{array}{c}\text { Balconista; } \\
\text { babá (12 } \\
\text { anos) }\end{array}$ \\
\hline $\begin{array}{l}\text { Motivação para ser } \\
\text { agente de saúde }\end{array}$ & $\begin{array}{c}\text { Trabalhar com } \\
\text { a comunidade } \\
\text { com } \\
\text { oportunidade } \\
\text { de renda; não } \\
\text { gosta de ficar } \\
\text { parada (aceita } \\
\text { também } \\
\text { trabalho } \\
\text { voluntário) }\end{array}$ & $\begin{array}{c}\text { Gosta da } \\
\text { área de } \\
\text { saúde; } \\
\text { experiência } \\
\text { com trabalho } \\
\text { voluntário na } \\
\text { comunidade; } \\
\text { curso de } \\
\text { voluntária do } \\
\text { Hospital do } \\
\text { Câncer }\end{array}$ & $\begin{array}{l}\text { Oportunidade } \\
\text { de emprego }\end{array}$ & $\begin{array}{c}\text { Oportunidad } \\
\text { e de } \\
\text { emprego } \\
\text { que } \\
\text { conversa e } \\
\text { lida com } \\
\text { pessoas }\end{array}$ \\
\hline $\begin{array}{l}\text { Tempo de trabalho na } \\
\text { Unidade }\end{array}$ & $\begin{array}{c}\text { Início da } \\
\text { Unidade de } \\
\text { Saúde da } \\
\text { Família }(8 \mathrm{~m})\end{array}$ & $\begin{array}{c}\text { Início da } \\
\text { Unidade } \\
\text { de Saúde } \\
\text { da } \\
\text { Família } \\
(8 \mathrm{~m})\end{array}$ & $\begin{array}{c}\text { Início da } \\
\text { Unidade de } \\
\text { Saúde da } \\
\text { Família }(8 \mathrm{~m})\end{array}$ & $\begin{array}{l}\text { Início da } \\
\text { Unidade de } \\
\text { Saúde da } \\
\text { Família } \\
\text { (8m) }\end{array}$ \\
\hline
\end{tabular}




\section{Aonde vão trabalhar os Agentes Comunitários de Saúde do QUALIS}

Através das entrevistas com os agentes, identifica-se a percepção de que o Programa implantado é essencialmente diferente do que existia anteriormente nos serviços de atenção básica. As Unidades de Saúde da Família foram instaladas em áreas consideradas como "carentes", muitas com equipamentos de saúde já existentes, mas praticamente desativados pela falta de profissionais. Os agentes relatam que o funcionamento de unidades de saúde vem, muitas vezes, responder às expectativas da comunidade para atendimento de suas necessidades, expressas através da mobilização popular:

O Posto aqui existia há 4 anos, só que com poucos recursos. Vinha médico de vez em quando, às vezes nem vinha e o bairro é grande e a necessidade é grande. Quando surgiu a oportunidade do QUALIS, a gente batalhou para conseguir... (Equipe 1, Agente 3)

A unidade, na verdade, já tinha; já tinha o posto aqui, mas era inativo. (Equipe 2, Agente 1)

Foi através da Igreja que veio o Posto. O Padre... é que correu atrás e também nós todos... Nossa! ... Nós lutamos três anos, foi assim uma luta forte,... uma luta muito boa e vitoriosa. O Padre falou assim: "Primeiro a gente entra na luta do Posto, a gente consegue o Posto, depois a gente faz a horta (comunitária)". (Equipe 2, Agente 2)

... Vacinei meu filho lá, eu nem vinha aqui porque esse posto aqui era muito abandonado, muito sombrio... acho que até por falta de verba mesmo não dava para eles cuidarem direito. (Equipe 3, Agente 2)

Esse projeto QUALIS na minha opinião foi uma luta da diretora. Porque se não fosse uma luta da diretora, que o Posto já estava quase fechado, ficou 2 anos sem atendimento, sem nada, só dentista e acho que as enfermeiras para dar vacina e tal. Não tinha médico. (Equipe 4, Agente 1)

Nas entrevistas, os agentes diferenciam a assistência médica clínica (em consulta ambulatorial ou em pronto-socorro) do que aparece como um diferencial positivo do PSF, a possibilidade de prevenção de problemas de saúde, de fazer diagnóstico precoce e de manter um acompanhamento:

Quando nós não tínhamos aqui, eles me relatam que iam procurar uma outra unidade, lá no ......., que é perto da linha. É do Estado, só que lá você precisava acordar às 3 horas da manhã para ficar na fila, para tentar passar em uma consulta. Ou ir ao 
pronto socorro quando estava doente... não existia prevenção da doença. (Equipe 1, Agente 1)

Não tinha aquele acompanhamento, não tinha aquela prevenção, não tinha uma orientação... era coisa de pronto-socorro, sem atendimento. (Equipe 1, Agente 4)

A gente vai lá no PAS e é tratado tudo rápido, faz a consulta rápida, nem olha para o rosto da pessoa, faz tudo de qualquer jeito. Aqui é um trabalho que a Doutora vai na casa... mesmo o trabalho de consultório, demora um pouquinho porque a Doutora conversa bastante, ela vê assim desde os pais... (Equipe 2, Agente 2)

As pessoas iam ao $P A S$, que não é tão próximo, para uma emergência, era onde elas iam. E era coisa assim de 4 ou 5 meses para conseguir uma vaga. (Equipe 4, Agente 3)

Quase todos os agentes relatam que, no início da implantação do PSF, os moradores visitados achavam que era uma proposta político-eleitoreira, mas que, com o tempo, foram vendo que era "uma renovação na saúde" (Equipe 2, Agente 1). Portanto, o PSF é vivenciado como uma reorganização da assistência à saúde, uma alternativa à prática assistencial hegemônica.

\section{O que é o QUALIS para os Agentes Comunitários de Saúde}

Para definir o Projeto no qual estão inseridos, os agentes comunitários de saúde do QUALIS fazem uma oposição entre a concepção de saúde e a de doença: ao contrário da forma de assistência predominante, o QUALIS não estaria voltado só para a atenção a doentes, mas incluiria as atividades de prevenção e promoção da saúde. Seu objeto de atuação também não se limitaria ao indivíduo, mas abarcaria a família. Como estratégia de atuação, a assistência não estaria centrada no trabalho do médico e no espaço do consultório, mas envolveria uma equipe na qual estaria incluído o próprio agente de saúde e a visita domiciliar:

O sistema de saúde curativo já existe em todos os lugares. No sistema de saúde do QUALIS a gente trabalha muito mais no sentido de prevenir para que no futuro talvez a gente possa ter uma condição de vida melhor. Porque não adianta estar fazendo o programa curativo e a doença permanecer, e retoma um pouco um sistema que antes existia, de conscientização, de (entendimento) que nem tudo depende do médico... (Equipe 1, Agente 3)

QUALIS é um projeto da familia, tem que trabalhar com a prevenção, prevenindo tudo... (Equipe 1, Agente 4)

O QUALIS não espera só as pessoas, a comunidade vir até o posto, nós vamos até eles. (Equipe 1, Agente 1) 
O QUALIS veio para tomar conta, para cuidar da população, que não é só saúde, tem a moradia, como a pessoa vive, se está empregada... o QUALIS veio para unir todas as pessoas em prol de uma coisa melhor para todas elas, para todos nós que moramos aqui. (Equipe 2, Agente 2)

Os outros postos de saúde que a gente tem aqui na região não têm o agente comunitário. Então, essa é a grande diferença que o pessoal sempre fala.. (Equipe 1, Agente 2)

Nós trabalhamos com cadastramento... cada agente tem no mínimo 200 famílias cadastradas. Para essas pessoas o agente faz visita domiciliar, trabalha com a visita, com orientações e prevenção. O que vem para o Posto é (a procura de) exames... porque a gente orienta sobre Papanicolau... e a procura por consulta médica... tem algumas pessoas que não entendem a prevenção, que tem a cabeça voltada mais para a consulta médica (Equipe 1, Agente 2)

O QUALIS procura ajudar o pessoal que está mais necessitado (Equipe 3, Agente 5)

PARA MUITOS É QUASE QUE NEM UM PRONTO SOCORRO. PORQUE PARA AS PESSOAS, ALÉM DE TER UM BOM ATENDIMENTO, PARECE QUE SE TORNA AMIGO DOS MÉDICOS. (EQUIPE 4, AGENTE 1)

Os agentes respondem, de forma imediata, que os grupos que têm prioridade são as gestantes, os menores de um ano, hipertensos, diabéticos e tuberculosos, mas não conhecem os motivos para a priorização desses grupos.

\section{Qual é o trabalho do Agente Comunitário de Saúde no QUALIS}

Os agentes destacam, no seu trabalho, a atuação preventiva, sendo que sua ação visa lidar com os hábitos, os comportamentos e as concepções das pessoas. A compreensão da relação entre saúde e doença mostra-se ampliada (em relação ao modelo médico biológico) e a atuação busca maior impacto, envolvendo atividades sobre o meio ambiente, as relações entre as pessoas e o estilo de vida:

Primeiro, a visita domiciliar, que é o centro (do trabalho) do agente. Na visita domiciliar a gente orienta... o aleitamento, o Papanicolau, sobre a verminose, sobre água filtrada, caixa d'água, é tudo na base da orientação... (Equipe 1, agente 4)

A gente precisa saber trabalhar a cabeça das pessoas... (Equipe 1, Agente 1)

Eles ainda têm a cabeça voltada para a consulta médica porque nós nunca tivemos um trabalho de prevenção que nem temos agora na região. (Equipe 1, Agente 2) 
Acho que o QUALIS veio para unir os moradores, unir as familias no conhecimento. Porque já que o médico atende todo mundo da mesma família, ele passa a conhecer cada membro da família, e não uma ...e os problemas de todos. Porque eu acho que muitas vezes a gente pensa que (o problema) está em um e não é: o problema está mais em outra pessoa da família, que acaba acarretando o problema geral. .... Mas não é só assistência médica, mas eu acho que é apoio... tem pessoas que precisam mesmo de atenção, de alguém para conversar, para desabafar seus problemas (Equipe 4, Agente 4)

A equipe de saúde valoriza as pessoas que fazem acompanhamento sem faltas e seguem a prescrição. O reconhecimento se dá quando a clientela segue as normas estabelecidas para o cuidado da saúde:

A Doutora gosta de tratar de pessoas que se preocupam com a saúde, marcam uma consulta e comparece. Agora, uma pessoa que não comparece aí já fica meio dificil, porque ela não sabe cuidar nem dela... aí já viu que o negócio está feio. É para fazer o acompanhamento certinho. (Equipe 2, Agente 2)

A diferença entre as formas de concepção dos cuidados da saúde é entendida como relacionada com a oferta de atenção: o QUALIS vem se implantar em muitas áreas onde a oferta anterior de assistência era do tipo atendimento a queixas, baseada em consulta médica. A oferta de orientações para prevenção é nova e não corresponde à experiência anterior da população.

No entanto, destaca-se a responsabilização individual pela saúde, não se estimulando, na maioria das situações, a solidariedade ou colocando em pauta os direitos sociais.

Eles ainda têm a cabeça voltada para a consulta médica porque nós nunca tivemos um trabalho de prevenção que nem temos agora na região... Se todo mundo fizesse um pouco o que a gente faz, não teria tanta desinformação. .As pessoas, com este trabalho que a gente faz, começaram a valorizar a própria saúde, porque, até então, eles achavam que a saúde deles dependia do médico - o que não é verdade. A saúde nossa é responsabilidade nossa. (Equipe 1, Agente 2)

50\% são pessoas muito resistentes... (Equipe 1, Agente 1)

\section{NO TERRENO DAS ORIENTAÇÕES, AQUILO QUE O AGENTE}

FALA ÀS VEZES NÃO VAI AO ENCONTRO DA EXPERIÊNCIA DA

FAMÍlIA COMO, POR EXEMPLO, NO CASO DO

ALEITAMENTO/ALIMENTAÇÃO DA CRIANÇA:

Você procura orientar no que é bom, mas se a mãe dela falar: "Dá o leite na mamadeira, minha mãe já deu e a gente está vivo..”. Então a gente tem que 
sensibilizar mesmo, tem que ir com jeitinho, com jogo de cintura, e sensibilizar. (Equipe 1, Agente 4)

Para opiniões conflitantes, valores e experiências diferentes, o agente vê, como estratégia, melhorar a forma de convencimento, colocando-se como portador do conhecimento verdadeiro. O reconhecimento do saber e da opção do outro, o diálogo, a troca de opiniões.... não se colocam como alternativa.

Os programas básicos de saúde precisam de insumos. Para os grupos de alto risco priorizados pelo PSF, como hipertensos e diabéticos, dispor do fornecimento regular da medicação é recurso fundamental para a prevenção de complicações cardiovasculares, além de meio de manter a própria aderência ao seguimento médico e os cuidados gerais, como dieta e atividade física. Sua falta implica sérias limitações ao trabalho da equipe e aos seus resultados:

Por mais que a pessoa (hipertensa) seja orientada sobre a dieta, sobre o lazer, sobre os problemas psicológicos, que elas podem aprender a melhorar suas condições físicas... o medicamento é primordial. (Equipe 2, Agente 1)

No fim do ano (1998), ficamos mais de 2 meses sem medicação nenhuma e aí a gente faz o trabalho todo de prevenção com diabético, com o hipertenso, todo esse trabalho... ele está fazendo a caminhada, está fazendo dieta, tudo direitinho, ai acabou a medicação. O desemprego aqui está geral e a pessoa não tem como comprar a medicação. $O$ médico não tem mais como fazer uma mudança porque nós não temos nada para trocar. Ai em um mês ou dois depois essa pessoa está com problema novamente... Esse mês, graças a Deus, chegou a medicação, vamos esperar que não venha a faltar... (Equipe 1, agente 3 )

\subsubsection{A prática dos Agentes Comunitários de Saúde do QUALIS}

A observação direta do trabalho dos agentes comunitários de saúde do QUALIS foi desenvolvida de acordo com a metodologia referida no capitulo correspondente. Os observadores acompanharam os agentes de saúde das equipes de saúde da família selecionadas para o estudo, de $2^{\mathrm{a}}$ a $6^{\mathrm{a}}$ feira, durante 8 horas por dia, em todas as atividades que eles realizaram, na unidade, no domicílio e na comunidade, efetuando todas as anotações no diário de campo. Essa sistemática possibilitou acertos entre o observador e o agente observado para que fosse acompanhado durante o período do dia em que o trabalho se desenvolvia, ou seja, das 7 às 16 ou das 8 às 17 , 
conforme escala de trabalho. Na medida em que o trabalho do agente, algumas vezes transcende esse horário, eventuais reuniões com a comunidade que ocorreram após o horário de trabalho não foram observadas.

CABE ESCLARECER QUE AS ANOTAÇÕES DOS OBSERVADORES FORAM LIDAS NO SENTIDO DE IDENTIFICAR, EM CADA VISITA, TODAS AS AÇÕES DESENVOLVIDAS, AS QUAIS FORAM DIFERENCIADAS POR SUAS CARACTERÍSTICAS. ASSIM, EM UMA MESMA VISITA, EM UM MESMO CONTATO COM UM USUÁRIO, EM QUALQUER LOCAL, FORAM ANOTADAS TODAS AS AÇÕES, O QUE EXPLICA QUE O NÚMERO DE AÇÕES IDENTIFICADAS É, E DEVERIA SER, PELA METODOLOGIA UTILIZADA, SUPERIOR AO NÚMERO DE OPORTUNIDADES DE CONTATO.

DISTRIBUIÇÃO DE ATIVIDADES E DO TEMPO DE TRABALHO DO AGENTE DE SAÚDE; AONDE E PARA QUEM SÃO DESENVOLVIDAS AS AÇÕES

CONFORME PODE SER CONSTATADO NO QUADRO 4.5, DO PONTO DE VISTA NUMÉRICO, A MAIOR PARTE DA ATIVIDADE DOS AGENTES É DESENVOLVIDA FORA DA UNIDADE, CONSTITUÍDA POR VISITAS DOMICILIARES OU CONTATOS REALIZADOS NA RUA; EM SEGUIDA ESTÃO AS ATIVIDADES REALIZADAS NA UNIDADE; AS AÇÕES NA COMUNIDADE OCORREM COM ÍNFIMA FREQÜÊNCIA. NO ENTANTO, EM TERMOS DA DISTRIBUIÇÃO DA CARGA DE HORAS DE TRABALHO, OS AGENTES PASSAM MAIS DE 50\% DO TEMPO NA UNIDADE DO QUE EM ATIVIDADES EXTERNAS*.

\footnotetext{
* Como constatado nas 10 unidades visitadas no Projeto "Novos Modelos de Assistência à Saúde: Avaliação do Programa de Saúde da Família no Município de São Paulo", os agentes comunitários de saúde permanecem dentro da unidade mais de $50 \%$ do seu tempo de trabalho, seja em atividades assistenciais (grupos educativos, acolhimento), seja em reuniões, seja organizando seu trabalho (e, às vezes, da equipe) e fazendo anotações. Nas unidades de saúde da região Leste (QUALIS I), os agentes trabalham, em média, 37.2 horas por semana, sendo $56.7 \%$ desse tempo dedicado a atividades dentro da unidade de saúde e 43.3\% utilizado para visitas domiciliares e trabalhos fora da unidade de saúde da família. Já os agentes da região Sudeste, durante a semana observada, permaneceram $61.9 \%$ da carga horária semanal média (38.38h) em atividades internas. Na região Norte, esse tempo dedicado a reuniões, relatórios, planejamento do trabalho, treinamentos e atendimentos à própria saúde foi de $63 \%$ da média total de horas trabalhadas na semana (39.26h).
} 
Apesar das visitas terem como local de realização os domicílios, ocupados na maior parte por famílias, e estas serem o alvo formal do Projeto, pôde-se constatar (Quadro 4.5) que as ações dos agentes são dirigidas em grande parte a uma pessoa do domicílio. Mesmo quando mais de uma pessoa é contatada, ou sobre as quais são colhidas informações, fica-se com a impressão de que a abordagem do agente, na imensa maioria das vezes, não se faz no sentido de considerar a dinâmica familiar, mas a somatória dos indivíduos que coabitam o domicílio.

\subsubsection{O desempenho do Agente de Saúde}

NO CAPÍTULO REFERENTE À DISCUSSÃO DA METODOLOGIA

USA-SE NA APRESENTAÇÃO DA METODOLOGIA USA-SE, A

TERMINOLOGIA "DESEMPENHO” PARA CARACTERIZAR A PRÁTICA

DOS AGENTES DE SAÚDE, CONCEITO QUE ENVOLVE TANTO AS AÇÕES

NO CAMPO DA SAÚDE E NA COMUNIDADE COMO AS INTERAÇÕES

ENTRE SUJEITOS.

\subsection{As Ações}

As ações caracterizadas neste Capítulo foram identificadas com base nos Cadernos de Observação dos Agentes Comunitários de Saúde. As vantagens dessa abordagem são enfatizadas por todos os pesquisadores que se dedicam ao estudo de metodologias com enfoque qualitativo. Lembra-se aqui, entretanto, no sentido de uma explicitação dos limites das informações aqui colocadas, em primeiro lugar, o fato de que os registros, a matéria prima utilizada para essa análise, foram elaborados por sujeitos que, embora treinados para que se pudesse garantir o máximo de isenção e de uniformidade, na ocasião da observação, certamente tiveram que fazer opções do que, segundo os seus valores e a exigüidade do seu tempo, seria o mais importante de ser registrado. Quanto às características do agente e à possibilidade de ele ter-se preparado para a observação, MENDES GONÇALVES (1994) em estudo das características tecnológicas do processo de trabalho na rede estadual de centros de saúde de São Paulo, chama a atenção para limites da coleta de dados através da observação direta do trabalho dos profissionais, ou seja, do "ambiente natural" em que a coleta de dados se desenvolve. Em primeiro, MENDES-GONÇALVES refere-se às possíveis conseqüências limitantes advindas do constrangimento dos sujeitos observados, 
inclusive o bloqueio do desenvolvimento dos trabalhos e, como mais importante, a possível "falsificação" dos procedimentos por referência aos que são habitualmente utilizados. A argumentação que ele desenvolve a favor da técnica centra-se na certeza de que se os agentes tendem a "aperfeiçoar" suas ações, na presença do observador, tendem a fazê-lo para melhor, o que já é um resultado ao indicar as concepções de que são possuidores acerca da sua prática e como elas devem ser desenvolvidas.

No caso do estudo a que se refere esta tese, os observadores e entrevistadores, reunidos com a pesquisadora após a conclusão do trabalho de campo, avaliaram que não identificaram constrangimento dos membros das equipes por ocasião das entrevistas, nem das observações. A outra situação lembrada por MENDES GONÇALVES, do "falseamento para melhor", segundo os coletores de dados, se ocorreu, foi apenas durante o primeiro dia. Eles avaliam que, na quase totalidade das situações, após um movimento meio de espanto, o que durou cerca de meio dia de trabalho, logo se colocaram à vontade e comentavam todos os assuntos com o observador, explicavam cada detalhe do trabalho e apresentavam-no às famílias com o orgulho de quem imagina que o seu trabalho foi "escolhido" para ser observado. $\mathrm{Na}$ maioria das unidades houve festa para o observador no último dia e até certificados de "sombra" foram conferidos. Um fato interessante, em relação aos agentes observados, que evidencia o modo como foi recebida a atividade, foi o questionamento por parte de vários deles, do por que "nós também não vamos ser acompanhados?", como se isso fosse um prêmio por um desempenho diferenciado.

Apresentam-se, no Quadro 4.6. as ações desenvolvidas pelos agentes,. na semana observada de trabalho. Em primeiro lugar, chamam a atenção a diversidade e a heterogeneidade em termos de conteúdo e de abordagem dos assuntos, nas visitas domiciliares observadas. Uma segunda observação, também bastante genérica, diz respeito à freqüência com que ocorrem determinadas orientações nas visitas. Se considerarmos a fala dos Agentes de Saúde nas entrevistas, em que eles identificam como ponto central do seu trabalho as orientações, especialmente sobre prevenção de doenças e sobre saneamento, na observação do Quadro 4.6, em nenhuma das equipes e semanas observadas isso se traduziu em uma prática preponderante. Ao contrário, como pode ser constatado, as ações em torno da assistência médica e do controle de riscos (reforço da conduta médica, controle de medicação/tratamento e ainda marcação de exames e consultas) é que representam a maior parte das atuações dos agentes. Por 
sua vez, identificou-se nas visitas uma série de "conversas" acerca da família, do emprego, dos acontecimentos no bairro, de comentários acerca da saúde e da doença, abarcada sob a sigla "ações comunicativas".

Quadro 4. 5. Distribuição das atividades de 8 agentes comunitários de saúde do QUALIS conforme local e para quem desenvolve a ação

\begin{tabular}{|c|c|c|c|c|c|c|c|c|}
\hline ATIVIDADES & $\begin{array}{l}\text { Equipe } 1 \\
\text { Agente } 4\end{array}$ & $\begin{array}{l}\text { Equipe } 1 \\
\text { Agente } 2\end{array}$ & $\begin{array}{l}\text { Equipe } 2 \\
\text { Agente } 1\end{array}$ & $\begin{array}{l}\text { Equipe } 2 \\
\text { Agente } 2\end{array}$ & $\begin{array}{c}\text { Equipe 3 } \\
\text { Agente 3 }\end{array}$ & $\begin{array}{l}\text { Equipe } 3 \\
\text { Agente } 5\end{array}$ & $\begin{array}{l}\text { Equipe } 4 \\
\text { Agente } 1\end{array}$ & $\begin{array}{l}\text { Equipe } 4 \\
\text { Agente } 2\end{array}$ \\
\hline $\begin{array}{c}\text { LOCAL DA } \\
\text { AÇÃO }\end{array}$ & & & & & & & & \\
\hline $\begin{array}{l}\text { Unidade de } \\
\text { Saúde }\end{array}$ & 21 & 12 & 11 & 30 & 20 & 06 & 13 & 22 \\
\hline Domicílio & 19 & 42 & 23 & 36 & 45 & 44 & 49 & 65 \\
\hline Comunidade & & & 02 & 02 & 04 & 01 & 02 & 01 \\
\hline Rua & 03 & 04 & 06 & 14 & 10 & 02 & 04 & 07 \\
\hline $\begin{array}{l}\text { PARA QUEM } \\
\text { DESENVOLVE } \\
\text { U A AÇÃO }\end{array}$ & & & & & & & & \\
\hline \begin{tabular}{|l|} 
Indivíduo \\
\end{tabular} & 19 & 19 & 22 & 26 & 39 & 13 & 48 & 64 \\
\hline $\begin{array}{l}\text { Família (mais do } \\
\text { que } 1 \text { pessoa no } \\
\text { domicílio) }\end{array}$ & 05 & 27 & 07 & 35 & 25 & 29 & 09 & 16 \\
\hline Grupo & 01 & & 02 & 01 & 02 & 02 & 04 & 03 \\
\hline Comunidade & & & & 03 & 01 & & & \\
\hline
\end{tabular}

Quadro 4.6 Distribuição das atividades dos agentes comunitários do QUALIS conforme natureza da ação

\begin{tabular}{|l|l|l|l|l|l|l|l|l|}
\hline \multicolumn{1}{|c|}{ ATIVIDADES } & $\begin{array}{c}\text { Equipe 1 } \\
\text { Agente 4 }\end{array}$ & $\begin{array}{c}\text { Equipe 1 } \\
\text { Agente 2 }\end{array}$ & $\begin{array}{c}\text { Equipe 2 } \\
\text { Agente 1 }\end{array}$ & $\begin{array}{l}\text { Equipe 2 } \\
\text { Agente 2 }\end{array}$ & $\begin{array}{c}\text { Equipe 3 } \\
\text { Agente 3 }\end{array}$ & $\begin{array}{c}\text { Equipe 3 } \\
\text { Agente 5 }\end{array}$ & $\begin{array}{c}\text { Equipe 4 } \\
\text { Agente 1 }\end{array}$ & $\begin{array}{c}\text { Equipe 4 } \\
\text { Agente 2 }\end{array}$ \\
\hline $\begin{array}{l}\text { NATUREZA DA } \\
\text { AÇÃO }\end{array}$ & & & & & & & & \\
\hline 1. Capacitação e & & & & & 01 & 01 & & 01 \\
\hline
\end{tabular}




\begin{tabular}{|c|c|c|c|c|c|c|c|c|}
\hline treinamento & & & & & & & & \\
\hline $\begin{array}{l}\text { 2. Planejamento/ } \\
\text { acompanhamento/ } \\
\text { avaliação das } \\
\text { ações de saúde }\end{array}$ & & & & & & & & \\
\hline $\begin{array}{l}\text { a - cadastramento } \\
\text { das famílias }\end{array}$ & & & \begin{tabular}{|l|}
01 \\
\end{tabular} & 05 & & 10 & \begin{tabular}{|l|}
01 \\
\end{tabular} & \\
\hline $\begin{array}{l}\mathrm{b} \text { - atualização de } \\
\text { cadastro }\end{array}$ & & & & 01 & & 04 & \begin{tabular}{|l|}
01 \\
\end{tabular} & \\
\hline $\mathrm{c}-$ coleta de dados & 11 & 28 & & 04 & 26 & 25 & 01 & 03 \\
\hline $\begin{array}{l}\text { d-consolidação } \\
\text { de dados }\end{array}$ & 01 & & & 03 & & & & \\
\hline $\begin{array}{l}\text { e - elaboração de } \\
\text { relatórios }\end{array}$ & 05 & 06 & 02 & 06 & 02 & 01 & \begin{tabular}{|l|l}
01 \\
\end{tabular} & 03 \\
\hline $\begin{array}{l}\text { 3. Reuniões de } \\
\text { equipe }\end{array}$ & 05 & 05 & 04 & 08 & 10 & 01 & 06 & 09 \\
\hline $\begin{array}{l}\text { 4. Ações } \\
\text { médico/sanitárias }\end{array}$ & & & & & & & & \\
\hline $\begin{array}{l}\text { A - prevenção e } \\
\text { monitoramento de } \\
\text { situação de risco e } \\
\text { meio ambiente } \\
\text { (vigilância } \\
\text { sanitária) }\end{array}$ & & & 03 & 01 & 01 & & & 01 \\
\hline $\begin{array}{l}\text { B - prevenção/ } \\
\text { monitoramento de } \\
\text { doenças } \\
\text { prevalentes/ } \\
\text { grupos espe- } \\
\text { cíficos de risco } \\
\text { (vigilância } \\
\text { epidemiológica) }\end{array}$ & 18 & 35 & 13 & 15 & 22 & 28 & 19 & 22 \\
\hline $\begin{array}{l}\text { C-promoção à } \\
\text { saúde }\end{array}$ & 01 & 10 & 10 & 06 & 01 & 03 & 06 & 01 \\
\hline $\begin{array}{l}\mathrm{D}-\text { ações de } \\
\text { reforço à conduta } \\
\text { médica }\end{array}$ & $\begin{array}{l}\text { Equipe } 1 \\
\text { Agente } 4\end{array}$ & $\begin{array}{l}\text { Equipe } 1 \\
\text { Agente } 2\end{array}$ & $\begin{array}{l}\text { Equipe 2 } \\
\text { Agente } 1\end{array}$ & $\begin{array}{l}\text { Equipe } 2 \\
\text { Agente } 2\end{array}$ & $\begin{array}{l}\text { Equipe } 3 \\
\text { Agente } 3\end{array}$ & $\begin{array}{l}\text { Equipe } 3 \\
\text { Agente } 5\end{array}$ & \begin{tabular}{|l} 
Equipe 4 \\
Agente 1
\end{tabular} & $\begin{array}{l}\text { Equipe } 4 \\
\text { Agente } 2\end{array}$ \\
\hline $\begin{array}{l}\text { E - ações de } \\
\text { controle de } \\
\text { medicação/ } \\
\text { tratamento }\end{array}$ & & 14 & 10 & 09 & 03 & 03 & 05 & 01 \\
\hline $\begin{array}{l}\text { F - marcar } \\
\text { consulta/exame } \\
\text { (inclui orientação) }\end{array}$ & 06 & 20 & 12 & 20 & 19 & 12 & \begin{tabular}{|l|}
07 \\
\end{tabular} & 22 \\
\hline $\begin{array}{l}\mathrm{G}-\text { ações de } \\
\text { prestação direta de } \\
\text { cuidado }\end{array}$ & 09 & 30 & 08 & 37 & 22 & 08 & 22 & 26 \\
\hline $\begin{array}{l}\text { 5. Ações } \\
\text { educativas }\end{array}$ & 01 & & & 01 & 04 & & 03 & 02 \\
\hline $\begin{array}{l}\text { A - questão } \\
\text { escolar }\end{array}$ & & & & & & & & \\
\hline
\end{tabular}




\begin{tabular}{|c|c|c|c|c|c|c|c|c|}
\hline $\mathrm{B}$ - trabalho & & 01 & & & & & & \\
\hline $\begin{array}{l}\mathrm{C}-\text { condição de } \\
\text { moradia/móveis/di } \\
\text { nheiro }\end{array}$ & & 01 & & 01 & & & & \\
\hline $\mathrm{D}$ - sexualidade & 01 & 04 & & & & & & 01 \\
\hline \multicolumn{9}{|l|}{$\begin{array}{l}\text { E- hábitos de } \\
\text { higiene (atividade } \\
\text { física, vestuário, } \\
\text { repouso, fumo) }\end{array}$} \\
\hline $\begin{array}{l}\mathrm{F} \text { - prevenção de } \\
\text { doenças }\end{array}$ & 01 & 09 & 01 & 01 & 03 & 09 & 06 & 03 \\
\hline $\begin{array}{l}\mathrm{G} \text { - planejamento } \\
\text { familiar }\end{array}$ & 04 & 18 & 13 & 08 & 17 & 22 & 16 & 19 \\
\hline \multicolumn{9}{|l|}{$\begin{array}{l}\mathrm{H} \text { - qualidade de } \\
\text { vida, relações } \\
\text { familiares }\end{array}$} \\
\hline I - estigma & & 03 & & & & 01 & & \\
\hline $\begin{array}{l}\mathrm{J} \text { - alimentação/ } \\
\text { amamentação/ } \\
\text { ervas medicinais }\end{array}$ & & & & & & & 01 & \\
\hline $\begin{array}{l}\text { 6. Ações } \\
\text { comunicativas }\end{array}$ & 08 & 20 & 02 & 02 & 04 & 04 & & 06 \\
\hline $\begin{array}{l}\text { 7. Ações de } \\
\text { assistência social }\end{array}$ & 18 & 11 & 15 & 27 & 22 & 22 & 10 & 11 \\
\hline $\begin{array}{l}\text { 8. Ações } \\
\text { comunitárias }\end{array}$ & 02 & & 02 & & & & 02 & 01 \\
\hline \multirow[t]{2}{*}{$\begin{array}{l}\text { 9. Ações } \\
\text { intersetoriais }\end{array}$} & 04 & & 07 & 02 & 01 & & & \\
\hline & 02 & & & 01 & & & & \\
\hline
\end{tabular}

Para melhor caracterização das ações dos agentes de saúde, agregamos, na seqüência, os conteúdos das reuniões de equipe (Quadro 4.7).

Houve oportunidade de registrar, apenas, 4 reuniões de equipe nas semanas de observação, sendo que 3 de uma única equipe. Ao todo foram caracterizadas 50 questões discutidas pelas equipes. Entre elas, destaca-se a ênfase não apenas na concepção dos problemas apresentados como relacionados com a condição do indivíduo (sob um enfoque principalmente orgânico e comportamental), a qual esteve presente na compreensão de 25 dos 50 problemas, mas também as discussões com destaque do caso clínico (19 casos). Entre as ações propostas, sobressai a marcação/remarcação de atendimento (12 das ações propostas), na maior parte das vezes com o médico de família da equipe. As relações familiares e as ações educativas e comunitárias quase não apareceram como temática nas reuniões de equipe. 


\subsection{As Interações}

Apresenta-se no Quadro 4.8 um condensado das interações realizadas pelos agentes de saúde nas suas atividades cotidianas observadas no espaço de uma semana, analisadas pelo ângulo da responsabilidade/ autonomia de ação e da postura e perspectiva de atuação do agente.

Como pôde ser constatado, destacam-se entre as responsabilidades do agente a prestação de informação, especialmente sobre acesso a serviços e ações de saúde, a função de elo comunicativo (mais estritamente entendido como levar mensagens e insumos da unidade à casa e vice versa) e a coleta de informações nas visitas mensais de rotina. Quanto à postura do agente, é nítida a hegemonia do pólo técnico em relação ao político-social, e da perspectiva de atuação institucional em relação à comunitária.

Quadro 4.7 Distribuição das temáticas discutidas em 4 reuniões de equipe do QUALIS conforme compreensão do problema, tipo de problema, conteúdo da ação proposta e discussão acerca do trabalho

\begin{tabular}{|c|c|c|c|c|c|}
\hline CARACTERIZAÇÃO DAS TEMÁTICAS & Equipe 1 & $\begin{array}{c}\text { Equipe 2 } \\
\text { Reunião 1 }\end{array}$ & $\begin{array}{c}\text { Equipe 2 } \\
\text { Reunião 2 }\end{array}$ & $\begin{array}{c}\text { Equipe } 2 \\
\text { Reunião } 3\end{array}$ & TOTAL \\
\hline Número de questões discutidas & 16 & 17 & 9 & 8 & 50 \\
\hline $\begin{array}{c}\text { I - Compreensão do problema/questão } \\
\text { Político-social }\end{array}$ & & 1 & 3 & & 4 \\
\hline Condições de vida & & 1 & & 1 & 2 \\
\hline Falta de recurso pontual & & & & & \\
\hline Estrutura familiar & 1 & 3 & & 2 & 6 \\
\hline Problema individual: Orgânico & 6 & 4 & 1 & 4 & 15 \\
\hline Psicológico & & 3 & 1 & & 4 \\
\hline Comportamental & 2 & 3 & & 2 & 10 \\
\hline Funcionamento do sistema de saúde/PSF & 2 & 2 & 2 & & 6 \\
\hline Novos cadastrados/solicitação de consulta & 3 & 4 & & 2 & 9 \\
\hline $\begin{array}{l}\text { II - Tipo de problemas } \\
\text { 1.VIGILÂNCIA SANITÁRIA/ AMBIENTE }\end{array}$ & & & 1 & & 1 \\
\hline $\begin{array}{c}\text { 2.VIGILÂNCIA À SAÚDE } \\
\text { Prevenção (vacina) }\end{array}$ & & 1 & & & 1 \\
\hline Óbito, internação/alta & & & & 1 & 1 \\
\hline Nascimento & 2 & & & & 2 \\
\hline
\end{tabular}




\begin{tabular}{|c|c|c|c|c|c|}
\hline Grupo de risco a)gestante & 1 & & & & 1 \\
\hline b) criança $<1$ ano & & & & 1 & 1 \\
\hline c) criança 1 a 5 anos & & 2 & & & 2 \\
\hline d) cardiovascular (HÁ, DM) & 2 & 3 & & 2 & 7 \\
\hline \multicolumn{6}{|l|}{ e) idoso } \\
\hline f) screening câncer gineco & & 1 & & & 1 \\
\hline 3. VIGILÂNCIA EPIDEMIOLÓGICA & 1 & 1 & & & 2 \\
\hline 4. PROMOÇÃO À SAÚDE & & 1 & & & 1 \\
\hline 5. CASO CLÍNICO/INDIVIDUAL & 9 & 6 & 1 & 3 & 19 \\
\hline 6. PROBLEMA DE SAÚDE MENTAL & & & & 1 & 1 \\
\hline \multicolumn{6}{|l|}{ III - Conteúdo/ação proposta } \\
\hline \multicolumn{6}{|l|}{ A - Médico Sanitária } \\
\hline Conferir suporte social & & 1 & & 1 & 2 \\
\hline Prestar informação & 5 & 2 & & & 7 \\
\hline Fazer orientação para autocuidado & & 1 & & 2 & 3 \\
\hline Levar mensagem/insumo & 1 & & 1 & 2 & 4 \\
\hline \multicolumn{6}{|l|}{ Colher informação } \\
\hline $\begin{array}{c}\text { Acompanhar/passar o caso para outro } \\
\text { profissional }\end{array}$ & 1 & 1 & & 3 & 5 \\
\hline Marcar/remarcar atendimento & 4 & 5 & & 3 & 12 \\
\hline Controle medicação/tratamento & & 1 & & 1 & 2 \\
\hline Controle exames & & 1 & & & 1 \\
\hline Controle faltoso/seguimento programático & 1 & 1 & & & 2 \\
\hline Nada proposto & & 2 & & & 2 \\
\hline \multicolumn{6}{|l|}{ B - Educativa } \\
\hline \multicolumn{6}{|l|}{ Escola, trabalho } \\
\hline Moradia & & 1 & & & 1 \\
\hline \multicolumn{6}{|l|}{ Sexualidade/planejamento familiar } \\
\hline CARACTERIZAÇÃO DAS TEMÁTICAS & Equipe 1 & $\begin{array}{l}\text { Equipe } 2 \\
\text { Reunião } 1\end{array}$ & $\begin{array}{c}\text { Equipe } 2 \\
\text { Reunião } 2\end{array}$ & $\begin{array}{l}\text { Equipe } 2 \\
\text { Reunião } 3\end{array}$ & OTAL \\
\hline Hábitos/higiene/comportamento & & & & 2 & 2 \\
\hline Relações familiares & & & & 1 & 1 \\
\hline \multicolumn{6}{|l|}{ Qualidade de vida } \\
\hline Alimentação/aleitamento & & 1 & & 2 & 3 \\
\hline \multicolumn{6}{|l|}{ Uso de serviços. de saúde } \\
\hline \multicolumn{6}{|l|}{$\begin{array}{c}\text { C-Comunicativa (conversas c/ usuário, } \mathrm{c} / \\
\text { família) }\end{array}$} \\
\hline \multicolumn{6}{|l|}{ D - Comunitária } \\
\hline Lazer & & & 1 & & 1 \\
\hline Reivindicação de serviços, benfeitorias & & & 2 & & 2 \\
\hline
\end{tabular}




\begin{tabular}{|c|c|c|c|c|c|}
\hline $\begin{array}{c}\text { IV - Organização de escalas, atividades, } \\
\text { agendas etc }\end{array}$ & 2 & 3 & 1 & & 6 \\
\hline $\begin{array}{l}\text { V - Discussão acerca do trabalho/modelo de } \\
\text { atenção do PSF }\end{array}$ & 1 & 5 & 3 & & 9 \\
\hline Trabalho em equipe & & 1 & 1 & 1 & 3 \\
\hline $\begin{array}{c}\text { Relação com - Comunidade ( C ) } \\
\text { Usuário(U) } \\
\text { Rede de serviço ( R ) } \\
\text { Intersetorial (T) }\end{array}$ & $\begin{array}{l}1 \mathrm{R} \\
1 \mathrm{U}\end{array}$ & $\begin{array}{l}2 \mathrm{U} \\
3 \mathrm{R}\end{array}$ & $\begin{array}{l}1 \mathrm{C}, 1 \mathrm{U} \\
2 \mathrm{R}, 1 \mathrm{~T}\end{array}$ & $1 \mathrm{U}$ & $\begin{array}{l}5 \mathrm{U} 1 \mathrm{~T} \\
6 \mathrm{R} \\
1 \mathrm{C}\end{array}$ \\
\hline $\begin{array}{l}\text { Informações clínica (terapêutica, evolução, } \\
\text { procedimento, relação médico-paciente) }\end{array}$ & 3 & 4 & & 7 & 14 \\
\hline \multicolumn{6}{|l|}{ VI - Natureza da questão discutida } \\
\hline $\begin{array}{c}\text { Assistência - Individual (I) } \\
\text { Familiar (F) } \\
\text { Comunidade (C) } \\
\end{array}$ & $13 \mathrm{I}$ & $\begin{array}{l}8 \mathrm{I} \\
2 \mathrm{~F}\end{array}$ & $1 \mathrm{I}$ & $\begin{array}{l}6 \mathrm{I} \\
1 \mathrm{~F}\end{array}$ & $\begin{array}{l}28 \mathrm{I} \\
3 \mathrm{~F}\end{array}$ \\
\hline Técnico administrativa & 1 & 9 & 6 & 2 & 18 \\
\hline Mista (Assis. ind. + técnico adm.) & & 3 & & & 3 \\
\hline Outra & & & 1 & & 1 \\
\hline
\end{tabular}

\section{Quadro 4.8 Distribuição das atividades de 8 agentes comunitários de saúde do QUALIS conforme natureza da interação}

\begin{tabular}{|c|c|c|c|c|c|c|c|c|}
\hline ATIVIDADES & $\begin{array}{l}\text { Equipe } 1 \\
\text { Agente } 4\end{array}$ & $\begin{array}{l}\text { Equipe } 1 \\
\text { Agente } 2\end{array}$ & $\begin{array}{l}\text { Equipe } 2 \\
\text { Agente } 1\end{array}$ & $\begin{array}{l}\text { Equipe } 2 \\
\text { Agente } 2\end{array}$ & $\begin{array}{l}\text { Equipe } 3 \\
\text { Agente } 3\end{array}$ & $\begin{array}{l}\text { Equipe } 3 \\
\text { Agente } 5\end{array}$ & $\begin{array}{l}\text { Equipe } 4 \\
\text { Agente } 1\end{array}$ & $\begin{array}{l}\text { Equipe } 4 \\
\text { Agente } 2\end{array}$ \\
\hline \begin{tabular}{|l|} 
NATUREZA DA \\
INTERAÇÃOO \\
I RESPONSABILIDADE/ \\
AUTONOMIA DE AÇÃO
\end{tabular} & & & & & & & & \\
\hline $\begin{array}{l}\text { 1. Toma decisão/tem } \\
\text { iniciativa }\end{array}$ & 07 & 19 & 16 & 19 & 03 & 02 & 08 & 05 \\
\hline $\begin{array}{l}\text { A - presta cuidados } \\
\text { físicos }\end{array}$ & 01 & 01 & & & 05 & & 07 & 03 \\
\hline $\begin{array}{c}\mathrm{B}-\text { prescreve } \\
\text { tratamento/ } \\
\text { atitude }\end{array}$ & 02 & 04 & & & 02 & & 07 & 03 \\
\hline $\begin{array}{l}\mathrm{C}-\text { desenvolve } \\
\text { orientações }\end{array}$ & 09 & 28 & 15 & 19 & 14 & 05 & 05 & 18 \\
\hline $\mathrm{D}-$ presta informações & 02 & 15 & 12 & 15 & 16 & 21 & 09 & 18 \\
\hline $\begin{array}{l}\mathrm{E}-\text { reforça conduta } \\
\text { médica }\end{array}$ & 03 & 07 & 10 & 13 & 05 & & 02 & 02 \\
\hline $\begin{array}{c}\mathrm{F}-\mathrm{faz} \\
\text { encaminhamentos }\end{array}$ & 01 & 22 & 14 & 12 & 20 & 09 & 07 & 08 \\
\hline
\end{tabular}




\begin{tabular}{|c|c|c|c|c|c|c|c|c|}
\hline $\begin{array}{l}2 . \text { Leva } \\
\text { mensagens/insumos }\end{array}$ & 02 & 12 & 12 & 15 & 25 & 18 & 22 & 33 \\
\hline 3. Colhe informações & 05 & 28 & 08 & 12 & 21 & 21 & 04 & 15 \\
\hline $\begin{array}{l}\text { 4. Acompanha outro } \\
\text { profissional }\end{array}$ & 09 & 05 & 03 & & 03 & & 20 & 20 \\
\hline $\begin{array}{l}\text { 5. Não se envolve com } \\
\text { solicitação do usuário }\end{array}$ & 01 & 05 & 03 & 07 & 02 & 05 & 01 & 01 \\
\hline \multicolumn{9}{|l|}{$\begin{array}{l}\text { II POSTURA DO } \\
\text { AGENTE }\end{array}$} \\
\hline $\begin{array}{l}\text { 1. Pólo técnico- } \\
\text { racionalidade do trabalho } \\
\text { clínico-sanitário }\end{array}$ & 18 & 42 & 24 & 66 & 53 & 38 & 55 & 70 \\
\hline $\begin{array}{l}\text { 2. Pólo político-social - } \\
\text { transformação } \\
\text { social/direitos }\end{array}$ & & 01 & 07 & 05 & 06 & 02 & 07 & 05 \\
\hline $\begin{array}{l}\text { 3. Omissão parcial/total em } \\
\text { relação ao usuário }\end{array}$ & 01 & & 06 & 10 & & 04 & & \\
\hline \multicolumn{9}{|l|}{$\begin{array}{l}\text { III PERSPECTIVA DE } \\
\text { ATUAÇÃO }\end{array}$} \\
\hline 1. Institucional & 18 & 39 & 27 & 64 & 52 & 38 & 54 & 69 \\
\hline $\begin{array}{l}\text { 2. Comunitária } \\
\text { (solidariedade, auto- } \\
\text { cuidado) }\end{array}$ & 01 & 01 & 10 & 08 & 06 & 01 & 12 & 06 \\
\hline
\end{tabular}

\subsection{Interação com a equipe, articulação com os outros profissionais}

O agente de saúde trabalha bastante articulado com a equipe (Quadro 4.8), interligando a casa e a unidade, as pessoas e os demais membros da equipe de saúde da família.

A equipe é constituída no processo de trabalho (PEDUZZI 1999): na finalidade comum do trabalho, na troca de informação, no espaço da reunião, no compartilhamento de tarefas, na homogeneidade da mensagem e da linguagem, na percepção/vivência de que um todo é maior (e mais forte) do que cada parte isolada:

No começo foi um pouco difícil, porque cada um tem o seu jeito de pensar, mas agora é bem dizer um casamento, já faz três anos que eu estou neste projeto, a gente já se conhece bem.... (descreve que a cor do olho do médico muda quando ele está bravo). (Equipe 2, Agente 2)

Trabalhar em equipe não é muito fácil não... mas a partir do momento que ela começa a mostrar para mim e eu começo a mostrar o meu ponto de vista para ela, a gente começa a discutir, ai se torna um serviço gostoso...que tem até muitas surpresas. (Equipe 2, Agente 1)

Eu acho super legal (trabalhar em equipe), porque numa equipe, quando acontecem problemas, e você não pode solucionar sozinho, então tem pessoas para você 
conversar, para te ajudar a resolver os problemas dos outros. E, graças a Deus, na nossa equipe a gente tem se dado muito bem. (Equipe 4, Agente 4)

Nós trabalhamos em equipe; a gente não trabalha sozinho... o agente comunitário não trabalha só. Nós somos uma equipe. O médico, a consulta médica, a orientação, a mesma linguagem que nós os agentes usamos lá ele usa no consultório quando as pessoas vêem. A enfermeira a mesma coisa. (Equipe 1, Agente 2)

É uma troca de conhecimentos, então aquilo que eu aprendo na rua eu passo para o médico, o enfermeiro passa, o médico passa, o auxiliar passa. Então, ali, na nossa reunião, nós somos todos iguais, há uma troca de conhecimentos. (Equipe 1, Agente 1)

A gente trabalha todos com o mesmo sentido. O médico no consultório, a gente na rua, o auxiliar também, o enfermeiro.... nós temos o mesmo sentido. Voltado para prevenir as doenças. (Equipe 1, Agente 2)

Tem dia que a gente chega aqui quase que arrasado mesmo, querendo desistir de tudo, ai a gente sempre encontra a equipe dando aquela força, levantando um pouquinho a moral da gente... um sempre dá força para o outro, um aprendendo um pouquinho com o outro. A gente se sente mais reforçada. (Equipe 1, Agente 3)

Encontra-se também um modelo de equipe em funcionamento mais hierarquizado, embora essa temática não vá ser objeto de discussão deste estudo:

Tem nós, os agentes comunitários que vamos nas casa, e pegamos tudo (de informação) que é preciso, as necessidades das pessoas, e trazemos para a enfermeira; a enfermeira passa para a doutora. Nós somos uma equipe. Tem vários casos que a enfermeira não precisa passar para a doutora e ela mesma já resolve. (Equipe 2, Agente 2)

Mas a concepção de equipe abarca o espaço da discussão:

A gente trabalha em um sistema de equipe. A enfermeira traz aquilo que a coordenação passou (para ser feito), o que a coordenação quer, mas aí a gente senta e discute. (Equipe 2, Agente 1)

\section{A REUNIÃO DIÁRIA APARECE COMO ESPAÇO DE} APRESENTAÇÃO DE SITUAÇÕES-PROBLEMA, COM TROCA DE INFORMAÇÕES SOBRE O CASO, TROCA DE OPINIÃO SOBRE COMO PROCEDER E PLANEJAMENTO DE AÇÕES MUITAS VEZES ENVOLVENDO A SOMA DE FORÇAS DA EQUIPE PARA LIDAR COM O PROBLEMA. 
A equipe todos juntos, faz a reunião, discute os problemas, todos, independente do médico, da enfermeira, da auxiliar, faz a reunião, passa caso para ver, quem pode ajudar um ao outro, às vezes eu não sei resolver sozinha e a enfermeira pode ajudar, o médico também e o auxiliar pode ajudar, então a equipe toda faz a reunião direitinho. (Equipe 1, Agente 4)

Nas reuniões a gente fala e cada um ajuda da melhor maneira. Te orienta: "Ah, você está com este problema? Eu já tive isso e eu fiz assim e deu certo." ... Existe uma troca com todo mundo. (Equipe 1, Agente 2)

O enfermeiro é reconhecido, pela maior parte das equipes observadas, como referência do agente e seu supervisor (na sua falta ou quando o agente considera que o problema é de natureza clínica, recorre ao médico da equipe). A reunião de equipe representa o espaço privilegiado de encontro, discussão e planejamento do trabalho dos agentes.

Quando a gente está assim meio perdido: "Mas como eu vou fazer isso?", eles orientam nós todas. Se a enfermeira está levo (a dificuldade) para ela; se a enfermeira não está, levo direto para o médico. (Equipe 1, Agente 2)

O enfermeiro ajuda bastante e avalia a gente no dia a dia, avalia assim, a gente faz uma reunião todo dia, e na reunião vai falando como que faz, como tem que fazer,... suas visitas não pode ser feita correndo, tem que ser assim, assim, tudo (é conversado) com jeitinho. (Equipe 1, Agente 4).

Sobre o controle do trabalho, os agentes relatam que trabalham com bastante autonomia, e que o controle seria mesmo desnecessário pela característica do trabalho ser em equipe:

A enfermeira e o médico ajudam em caso de dificuldade... mas hoje em dia não tem como te acompanhar, como te vigiar. Você trabalha junto, você trabalha unido.(Equipe 2, Agente 1)

Para casos de dificuldade de aderência do cliente à terapêutica ou ao seguimento, os agentes acham que a população não valoriza a sua opinião devido a sua escolaridade e função. Nestes casos, enxergam no enfermeiro e no médico um poder de convencimento maior:

O povo vê com a mente antiga, que o médico e a enfermeira tem mais entendimento, a gente não. Eu entrei e aprendi muita coisa, eu sei como orientar, tudo, então você orienta, mas precisa às vezes de um reforço, de uma enfermeira, isso ajuda muito. (Equipe 1, Agente 4) 
A integração dos trabalhos dos membros da equipe para o agente muitas vezes aparece como um ajuda mais pessoal e não organização técnica do trabalho:

As enfermeiras ajudam muito a gente, porque às vezes a gente tenta falar com as pessoas, ela às vezes recebe mas não acata, e o enfermeiro indo, ela já vê que é uma pessoa estudada, uma pessoa que fez faculdade, ai elas recebe mais. (Equipe 1, Agente 4)

\subsection{Interação com o indivíduo, com a família, com a comunidade Caracterização da área e população pelos agentes}

Conforme apresentado abaixo nos excertos das entrevistas, a imagem geral dos agentes acerca da área e da população-alvo do Programa é de carência, às vezes ao lado de regiões e famílias com melhores condições de vida. Nos bairros de pior qualidade de vida faltam recursos como saneamento, asfalto e iluminação. Para a população, muitas vezes a renda é considerada baixa e falta emprego. Muitas são áreas de tráfico de drogas e sem espaços de lazer. Alguns dos agentes relacionam as más condições de vida com a emergência de doenças, como as mentais, e a dificuldade de manter o cuidado da saúde.

\section{É área carente. (Equipe 1, Agente 1)}

O bairro tem lugar, na minha área, na minha micro-área 5, eu não tenho problema, porque é asfaltada a rua, tem tudo. Agora tem áreas, realmente tem lugares aqui no bairro que é muito pobre, muito difícil, não tem esgoto, o esgoto é a céu aberto, não tem água, quando falta água da rua eles ficam uma semana sem água, muitas crianças andam de pé no chão. (Equipe 4, Agente 2)

Este é um bairro muito dificultoso, um bairro pobre. Hoje já está até um pouco melhor... Mas mesmo assim tem muita gente desempregada, não temos assim área de lazer... escolas até a gente tem, isso eu não posso reclamar... mas mesmo assim, ainda existem algumas crianças que têm dificuldade de estar arranjando vaga, porque as escolas são superlotadas. Posto de saúde também são poucos: é esse daqui e outro que não é do QUALIS. Nós aqui, às vezes a gente fica muito triste porque vem muita procura para nós... (Equipe 1, Agente 2)

$O$ bairro é precário, pessoas muito carentes... não tem muito recurso, não tem diversão, nem alguma coisa para os adolescentes, nada disso. (Equipe 1, Agente 4)

Pouca gente paga aluguel, a maioria é proprietário. (Equipe 1, Agente 3)

São casa da periferia, mas são casas de tijolos. (Equipe 3, Agente 2)

O pessoal, por ter casa própria, eles acham que não precisam de mais nada... a gente convida as pessoas e elas não comparecem... mas tem gente que ainda passa fome. É muito dificil fazer trabalho aqui. (Equipe 2, Agente 2) 
Eu acho que o problema mais grave aqui é o desemprego, são as drogas. Tem hipertensos, depois diabéticos, crianças aqui tem poucas... são mais pessoas da terceira idade. (Equipe 2, Agente 2)

O bairro aqui às vezes é bastante agitado, porque aqui tem muito tráfico. Então dificulta um pouco o nosso trabalho por causa disso. O pessoal acha que a gente é da polícia e aí eles ficam um pouco cismados. (Equipe 3, Agente 5)

Tem um número muito grande de famílias depressivas. Você percebe que aquele fechamento, aquele medo de violência, aquela falta de confiança, aquela falta de contato humano, estão tornando a família doente. (Equipe 2, Agente 1)

\section{As atividades-fim do Agente Comunitário de Saúde}

Ainda para caracterizar as ações e interações, apresentam-se informações sobre o trabalho colhidas nas entrevistas realizadas com os próprios Agentes Comunitários de Saúde, constituindo-se em expressões de que esses agentes se utilizaram para referir-se a sua prática, ou como coloca MENDES-GONÇALVES, “(....) as informações sobre os momentos tecnologicamente significativos dos processos de trabalho consistem em representações, assumidas como ideologicamente estruturadas, das quais os agentes do trabalho são portadores, tais como manifestadas na situação concreta da pesquisa “. Entretanto, embora aborde que essa ocorrência pode constituir-se em limites do estudo, o autor considera que "as inconsistências que eventualmente possam existir entre a tecnologia realmente operante $e$ as representações daqueles agentes e mais, que outras inconsistências que também possam ter-se verificado entre aquelas representações, tais como ocorrem habitualmente, e as representações manifestadas nas entrevistas..." não alteram significativamente as conclusões na medida em que outras abordagens que foram utilizadas para apreensão do objeto, podem constituir-se em mecanismos de controle e de superação de possíveis prejuízos (MENDES GONÇALVES 1994, 131).

No caso do objeto de estudo deste trabalho, consideram-se as representações dos agentes sobre o seu trabalho como uma das dimensões importantes a serem apreendidas, constituindo-se já como resultado a ser utilizado na caracterização do perfil ocupacional. 
Segundo os agentes de saúde, eles têm, basicamente, três atividades-fim, dirigidas aos indivíduos, famílias e comunidade: a visita domiciliar, atividades em grupo (na maioria das vezes entre educativas e assistenciais) e atividades comunitárias.

\section{Visita Domiciliar}

A visita domiciliar é considerada atividade primordial do PSF e atribuição primeira do agente. Eles destacam nas entrevistas o conteúdo de orientação/prevenção da visita.

Conteúdo básico da visita domiciliar para coleta de informações conforme apreendido no cotidiano do trabalho dos agentes:

- Checar se está "tudo" bem, como a pessoa está se sentindo, se a família precisa de alguma coisa;

- Vigilância: atualização vacinação, screening citologia oncótica, uso continuado de medicação para hipertenso e diabético, controle se está fazendo acompanhamento programático (gestante, menor de 1 ano, hipertenso, diabético);

- Confere acesso à medicação prescrita (situação de falta de fornecimento de medicação na UBS, relatada pelos profissionais da equipe e lideranças comunitárias). Busca alternativas se o usuário não pôde comprar medicação (terapêutica alternativa, contato com o médico para troca de medicação);

- Intermediação clientela-médico: acesso à medicação, como lidar com efeito colateral medicação, encaminhamento para segunda linha/serviço de referência, interconsulta (avaliação clínica de sintomas ou exames quando consulta agendada a prazo considerado muito longo);

Eu visito as pessoas, vejo se tá tudo bem, passo orientações, para as pessoas que não tomam medicação a gente tenta orientar... e se não tiver dinheiro, a gente tenta dar um contorno, faz um chazinho, uma medicação alternativa, ou a gente volta, trás o problema para o médico e ele vai ver se tem alguma outra medicação na nossa unidade, para ele trocar. Esse é o nosso trabalho, ver se a vacina está em dia, se a gestante está sendo acompanhada todo mês... a gente tenta descobrir casos de tuberculose que está tendo muito na área... ... (Equipe 1, agente 1)

A visita articula-se com o trabalho da equipe, especialmente quando o agente encontra um problema, o qual ele leva para discutir com a enfermeira, sua referência, ou para a reunião diária. Nas situações detectadas como problemáticas, que na maior parte das vezes está relacionada com o monitoramento de situação de risco epidemiológico (aderência a tratamento, cuidados da criança menor de um ano, falta 
repetida a atendimento, recusa de procedimento de screening), muitas vezes se conclui pela necessidade de um reforço do trabalho do agente, agendando uma visita acompanhado pelo auxiliar ou pelo enfermeiro.

A gente orienta tudo. Em alguns casos que a gente não pode fazer nada, traz para a equipe e discute com a equipe o que pode ser feito. (Equipe 1, agente 4)

$\mathrm{Na}$ visita, além da atividade educativa mais formal, existe um espaço de suporte, em que o ouvir, informar e aconselhar são instrumentos potenciais de trabalho. No entanto, essa parte do trabalho apareceu raramente nas observações de campo, o que indica que não é realizado de forma sistemática, mesmo quando se identificam oportunidades de abordagem, como a apresentada na seqüência:

Visita domiciliar - Agente de saúde 2, Equipe1

Agente: Você está trabalhando?

Mulher: $\quad$ Em Guarulhos, até as 10 horas da manhã. Turno de 12 horas.

Agente : Você está bem?

Mulher: Vai levando, como Deus quer.

Agente: E $\quad$ a saúde?

Mulher: $\quad$ Tem uns caroços pelo corpo, e a ...(filha) que temos e coça muito. Eu vou fazer exame hoje no Hospital (onde trabalha) para ver o que é. Um médico disse que pode ser micose... sarna não é... Vivendo só está dificil!

Agente: Como só?

Mulher: $\quad$ Meu marido foi embora tem três meses. Se engraçou com uma princesinha do centro da cidade e foi embora.

Agente: E o Papanicolau?

Mulher: Eu fiz em uma campanha.

Agente: Faz um ano?

Mulher: Ainda não.

Agente: No serviço está tudo bem?

Mulher: $\quad$ Tá meio fraco, mas está bom.

Agente: Você já passou a ... (filha) pelo médico?

Mulher: $\quad$ Eu tenho preguiça, mas vou levar. O médico do Posto encaminhou para o Dermatologista do ..., mas lá é só pela misericórdia. O hospital onde eu trabalho é particular e é longe. Eu passei sabonete de enxofre e ela não pega mais o cachorro no colo. Eu também brincava. Dei Polaramine e Decadron e também não deu certo. Agora é só médico mesmo.

(a agente se despede)

O AGENTE DE SAÚdE NÃO COMENTA O ABANDONO PELO MARIDO, QUE PODERIA SE DESDOBRAR EM ATUAÇÃO DE PROMOÇÃO 
DA SAÚDE E EM MOBILIZAÇÃO POR DIREITO SOCIAL. A VISITA GIRA EM TORNO E FICA RESTRITA À VIGILÂNCIA À SAÚDE.

A SITUAÇÃO DE PROBLEMAS NA RETAGUARDA CLÍNICA ESPECIALIZADA E DO ATO PÚBLICO PROGRAMADO PARA APOIO AO HOSPITAL A SER REALIZADO NA SEMANA NÃO É EXPLORADA PELA AGENTE NA SEGUINTE VISITA:

VISITA DOMICILIAR - AGENTE DE SAÚDE 4, EQUIPE 1

AGENTE: E O SEU FILHO PASSOU NO MÉDICO? FEZ EXAMES? MULHER: PASSOU, MAS COMO ELE TEM SINUSITE MANDOU UM REMÉDIO... É O QUE TINHA NA FARMÁCIA DO POSTO. EU ACHO QUE SE PRECISAVA DE OUTRO (REMÉDIO) PODIA FALAR E EU COMPRAVA....E O HOSPITAL... QUE TODO MUNDO ESTÁ FALANDO QUE VAI FECHAR? NÓS ESTAMOS FAZENDO CARTAS PARA O GOVERNADOR, PARA O PREFEITO, TUDO PARA NÃO FECHAR, PORQUE SEM ESTE HOSPITAL O QUE SERÁ DE NÓS AQUI?

AGENTE: VOCÊ TEM CONSULTA COM O DR ... (NA USF)?

MULHER: PASSEI AGORA NA TERÇA-FEIRA E ELE MARCOU PARA VOLTAR EM DOIS MESES, MAS EU TENHO QUE TIRAR RX PARA SABER SE É SINUSITE. VOU NO ... TIRAR, MAS EU ACHO QUE 2 MESES É MUITO TEMPO PARA LEVAR O RX PARA ELE VER.

AGENTE: O QUE EU POSSO FAZER É LEVAR O RX PARA O DR VER E, SE FOR MESMO SINUSITE, ELE FAZ A RECEITA E EU TRAGO PARA VOCE

MULHER: É, ESTÁ BOM... PORQUE EU TENHO ALERGIA A PÓ, A CHEIRO E FICO COM O NARIZ TODO TAMPADO

(AGENTE ORIENTA LIMPEZA DA CASA PARA CUIDADO COM POEIRA)

ESSE É UM EXEMPLO DE SITUAÇÃO QUE PODERIA SE DESDOBRAR EM INCENTIVO À ORGANIZAÇÃO DA COMUNIDADE PARA O EXERCÍCIO DO CONTROLE SOCIAL E PROMOÇÃO DE CIDADANIA (PARTICIPAÇÃO DO INDIVÍDUO DA DECISÃO SOBRE 


\section{ASSISTÊNCIA; DIREITO À SAÚDE, MOBILIZAÇÃO, ATUAÇÃO DO CONSELHO DE SAÚdE) QUE NÃO SE REALIZA. A ATUAÇÃO GIRA EM TORNO DE CONSUMO DE CONSULTA E MEDICAÇÃO; AGENTE LEVA E TRAZ EXAME E RECEITA ENTRE A CASA E O POSTO.}

Por outro lado, o trabalho de apoio não é reconhecido pelo agente como uma atividade técnica, mas das relações humanas:

Às vezes o idoso não tem com quem conversar, não tem com quem desabafar, a gente chega lá e eles conversam, falam, choram e isso é bom, porque as pessoas desabafam, tiram para fora o que sentem, a gente tenta dar um conselho. Para aquelas pessoas sem juizo, adolescentes, que querem abortar, quer fazer alguma coisa, a gente conversa, explica direitinho. Então eu me sinto prestativa, apesar da gente não poder fazer muita coisa, só orientar, conversar. (Equipe 1, agente 4)

Quando tem um problema que eles não podem vir até aqui, a gente vem, procura conversar com o médico, levar uma orientação de volta para eles, em questão de medicamento... porque muita gente não sabe ler. E muitas vezes para conversar mesmo, para parar e ouvir a pessoa, porque muitas vezes tem pessoas com problemas ..você vê que não é tanto doença, mas elas precisam de alguém que pare para escutálas. (Equipe 4, Agente 4)

A situação de carência de diversas ordens — social, afetiva, de informação - e a ênfase do PSF nas ações de vigilância à saúde, cria as condições para que a faceta de suporte do trabalho do agente seja reconhecido como de assistência social, quase caritativo, feito por sua própria iniciativa e baseado na sua experiência de vida.

\section{Grupo Educativo-Assistencial}

Há uma série de grupos educativo-assistenciais, alguns preconizados pelos programas mais tradicionais, outros conforme a criatividade e habilidade da equipe, como para gestantes, diabéticos, oficina terapêutica, caminhada (com controle de peso mensal), amamentação; mas ainda grafite e capoeira, trabalhos manuais etc... Eles cobrem uma gama de finalidades: desde um papel mais educativo, muitas vezes oferecendo assistência suplementar ao atendimento médico; até atividade de lazer e cultura, como sabemos praticamente ausente em muitos bairros.

A mãezinha que é a primeira vez que está grávida, ela vai vir porque nesses grupos ela aprende, elas aprendem. E também aquele diabético que não conseguiu marcar 
consulta, então a gente reúne aqueles que não passaram em consulta aquele mês para fazer um grupo para ver como eles estão se saindo. (Equipe 1, agente 1)

Os grupos acontecem na unidade e na área. Estes últimos são marcados pelos agentes e conduzidos com a participação de um médico quando o trabalho na unidade não está muito apertado. O seu principal objetivo parece ser a passagem de informação sobre a condição de risco e a necessidade de manutenção de cuidados.

(para o caso de uma pessoa teimosa para tomar medicação) Se for o caso a gente confronta, através de uma palestra, dos grupos que a gente forma, a gente confronta um com o outro, a gente pede depoimento. Através desses depoimentos a gente vai criando uma flexibilidade que acaba dando resultado. (Equipe 1, agente 3)

Tem um hipertenso na minha área e ele sofre de alcoolismo. Então é difícil o trabalho com essas pessoas. Eles começam, eles vêm ao posto, eles passaram pelo médico de família, foram orientados, fizeram exames, medicados... mas só que eles não seguem a orientação, nem do médico de família. Então fica difícil. Agora... teve na semana passada, nós fizemos um grupo de hipertensos, e eu estou convidando essas pessoas para participar do grupo... para eles estarem sabendo do mal que eles estão fazendo para a saúde deles. Ter um conhecimento mais profundo sobre o que vai fazer a falta de medicação... (Equipe 3,

Agente 3)

Teve uma mãe que teve problema de não querer amamentar. A gente explicava para ela a importância do aleitamento, mas ela achava que o leite só não ia sustentar a criança, que ela precisava tacar leite engrossado. Como a Dra... tem um grupo de aleitamento materno, eu trouxe ela para conversar, para ver, até para se unir junto com outras mães, solucionar as dúvidas dela e ela... conseguir resolver. (Equipe 4, Agente 4)

\section{Vida / Atividade Comunitária}

Se nas atividades dos agentes de saúde, observadas durante uma semana, as ações comunitárias foram praticamente inexistentes, nas entrevistas há uma série de fatos relatados, evidenciando que elas ocorrem de forma esporádica e muitas vezes como resposta a situações de maior tensão ou mobilização social. Encontram-se relatos relacionados com saneamento (lixo), segurança, fome e desemprego, atividades de lazer e reivindicação de equipamentos sociais.

Apesar de esporádicos, como representam ações de cidadania, previstas no Programa de Saúde da Família do QUALIS, considera-se importante analisá-los.

Os problemas sanitários são enfrentados de duas maneiras: no contato individual ou através de abordagem em grupo. No primeiro caso, o objetivo é mudar o 
comportamento de cada família; no segundo, criar alternativa coletiva para lidar com um problema que transcende a casa, atingindo a rua/bairro:

Na comunidade, é mutirão quando a gente vai tomar uma providência a respeito do lixo, por exemplo. Então vai todo mundo em mutirão... a gente vai de casa em casa, orientando sobre o lixo, sobre a dengue, sobre a limpeza da caixa d'água. (Equipe 1, agente 2)

A minha área é a mais carente...uma área invadida. Então foi feita uma lixeira comunitária, para eles não porem aquele lixo no chão, que aí vai criar rato, vai criar um monte de doença. Agora eles põem em uma sacolinha, amarram, para quando o lixeiro passar não estar mais o lixo no chão... Nessas visitas que a gente faz diariamente a gente tenta orientar as pessoas, conversa direitinho. Mas a pessoa diz: “Ah., mas não sou eu, é o vizinho"... Não aparece o culpado. Então a gente vai reunir todos aqueles daquela rua para falar. Então a gente fala com todos para eles pensarem: "Ah, ela está falando com ele também, com ele, com ele". Fazendo assim eu vi que tem jeito, não só você falando de cabeça em cabeça. Reúne, fala no grupo todo, aí eu vi que tem solução. O grupo é muito bom... E foi orientado a eles, eles mesmos fizeram a lixeira... (Equipe 1, agente 1)

Notar que o agente de saúde, baseado na sua experiência, concluiu que esta é uma estratégia de maior rendimento para problemas coletivos. No entanto, a solução se faz sem envolver o poder público.

Sobre o problema da segurança, transcreve-se o seguinte relato em que se destaca a relação da população com o equipamento social e a sua "resposta" quando acionada pelos profissionais da equipe de saúde:

Nessa semana que passou nós tivemos um caso de assalto no Posto que já tinha sido assaltado 5 vezes. Na quinta vez foi impossível a gente estar resolvendo sozinha. Ai a comunidade foi envolvida. Graças a Deus, no prazo de duas horas, a gente reuniu aqui 300 pessoas. A Globo veio, foi feita uma denúncia, a gente foi até a Delegacia da área, foi feito um BO. Fizeram uma promessa para nós que o nosso problema vai ser resolvido. E a gente está confiando nisso, porque se não resolver, a gente vai cobrar novamente... Quando precisa da comunidade, a gente vai atrás sim. (Equipe 1, agente 3)

As reuniões do Comitê da Fome são feitas na unidade da Equipe 1, participam as pessoas da comunidade. Antes participavam agentes de saúde; atualmente eles vão a algumas reuniões para passar ou receber informações que depois transmitem à equipe na sua reunião de rotina. Mas continuam interferindo, "fazendo andar": 
Como cada um tem que trabalhar também para sobreviver, o Comitê está caminhando um pouco devagar diante da necessidade que a gente tem. Nesta semana a gente se reuniu e estamos pretendendo agora no final de semana, neste ou no próximo,... fazer um Bingo para estar angariando fundos... E a gente está pensando assim também: de cada uma de nós estar conquistando uma pessoa que assuma a responsabilidade de estar dando. Já foi discutido na equipe, falta a gente colocar em ação. (Equipe 1, agente 3 )

Os agentes descrevem que coletaram informações sobre número de desempregados em sua visita rotineira às famílias. Além disso, a unidade sediou as reuniões no bairro para indicação de comissões para organização das frentes de trabalho, cuja iniciativa foi do governo do Estado.

Está tendo um movimento para frentes de trabalho... para tentar ver se diminui um pouco o desemprego. Esta questão da frente de trabalho já vai vir para nós, para a nossa região. Na semana passada já teve uma reunião aqui no Posto, onde contou-se com 270 desempregados, destes 270 foi tirada uma comissão, já foram para ... para outra reunião ela vai se informando e trazendo informação para os que ficaram... (Equipe 1, agente 2)

As atividades para terceira idade podem ser mais vinculadas à promoção da saúde e/ou ao lazer. Diferentes instituições podem participar, havendo tanto uma integração quanto, às vezes, uma disputa pela clientela:

A gente faz reuniões, palestra... a Doutora vem e dá a palestra, aí a gente passeia com eles. Antigamente a gente fazia bailinhos com eles, mas agora parou um pouco. A parte que eu mais gostava era do baile, porque tem pessoas muito triste que vindo para esse bailinho ficam alegre... Nós é que fundamos (o bailinho), agora os padres lazaristas fundaram lá também e as pessoas ficam divididas. Só que o nosso trabalho é melhor do que o deles, porque o nosso tem orientação, e o deles não, é só o baile. (Equipe 2, agente 2)

$\mathrm{Na}$ reivindicação de equipamentos sociais os grupos mobilizados e mobilizáveis tendem a se somar, como na situação descrita abaixo:

Tem as pessoas das entidades que entregam leite... tem duas entidades. Eles participam muito com a gente, eles lutam junto com a gente para que tenha creche. Quando a gente faz alguma reunião, eles participam... A maioria das reuniões é pelo Posto, mas tem outras que eles se reúnem entre eles e passam para a gente e aí nós pega e vamos... porque quando a gente faz alguma coisa, eles participam. (Equipe 1, agente 4)

Além da luta por saneamento e energia, parece que mais recentemente tem havido mobilização para equipamentos de lazer. 
Alguns agentes de saúde destacam na entrevista, entre as sugestões, a necessidade de maior número e diversidade de equipamentos sociais, mas não levantam a possibilidade de um trabalho articulado entre a unidade de saúde da família e esses equipamentos sociais:

(Sugiro) áreas de lazer, porque as pessoas ficam doentes não é só por uma dor, às vezes é até depressão, filho na rua, que é o que tem muito por aqui ... A gente não tem área de lazer. Então tem muitas coisas que poderiam ajudar também, além de postos de saúde (do QUALIS). Áreas de lazer, escolas profissionalizantes... . Tem jovem, adolescente que com esse desemprego não conseguem trabalho; eles estudam à noite e ficam parte do tempo, de dia, sem fazer nada. E o que eles fazem ? Vão para rua. Com isso os pais acabam ficando preocupados e acabam ficando doentes. (Equipe 1, agente 2)

Por outro lado, identificam-se experiências de sucesso na parceria entre movimento social e unidade de saúde, como na área da Equipe 3, onde foi construído um galpão para atividades comunitárias com o apoio da unidade, no qual é realizado o grupo de atividades manuais.

Foram encontrados dois outros relatos de atividade das equipes de saúde no suporte de determinadas pessoas da comunidade, realizado principalmente pelos próprios membros da equipe e com participação especial do agente comunitário de saúde:

- A Equipe 3 tem sob sua responsabilidade uma família com um adolescente portador de doença mental, cuja mãe saiu de casa. A família fez contato com ela em Santos, o agente foi conversar com ela, a equipe fez um mutirão de pintura e arrumação da casa para a sua volta e o agente mantém um calendário periódico de visitas a essa família.

- A Equipe 4 tem sob sua responsabilidade uma senhora com deficiência visual e de locomoção com mais de 90 anos; ela mora embaixo da casa do filho, mas ele não cuidava dela. A agente de saúde encontrou-a, na primeira visita, muito suja e angustiada na cama. A equipe decidiu que, na falta da atenção da família e vizinhos, cuidaria da senhora e as agentes se revezam em visitas diárias para cuidado da senhora, incluindo banho e alimentação. Conseguiram uma cadeira de rodas na qual levam a senhora para tomar sol, e um rádio, pois ela gosta de ouvir notícias. A agente e a senhora conversam, de mãos dadas.

Este conjunto de situações e ações sociais indica que a organização da população parece se dar muitas vezes a reboque da mobilização desencadeada pelos funcionários da unidade básica (como se pode identificar na manifestação pela 
segurança), ou alavancada por alguns funcionários que, em um segundo momento, afastam-se da linha de frente da organização (como o Comitê contra Fome). O Posto serve, também, como espaço de reunião para responder a políticas sociais mais amplas (como no caso da organização de frentes de trabalho para desempregados).

A participação popular é considerada pelos agentes como uma prática complexa:

Esse bairro evoluiu muito. Há um tempo atrás nós não tínhamos nada, depois que veio chegando o progresso, as escolas. Foi com muita reivindicação, muita luta junto à Prefeitura... buscando melhorias. Hoje a gente já vê que a população se conscientizou que, se unindo, se consegue. Então isso foi bom, pelo que eu vi nesses 32 anos aqui no bairro. (Equipe 4, Agente 3)

A comunidade na verdade eles querem tudo pronto. Quando faz uma reunião, eles participam, mas não totalmente. de cem pessoas vem umas quarenta, porque eles não querem ter trabalho, eles querem a coisa pronta... mas sempre participa, alguém sempre vem. (Equipe 2, Agente 2)

DE QUALQUER FORMA, A ESTRUTURA FÍSICA DA UNIDADE DE SAÚDE E OS AGENTES REPRESENTAM ESPAÇO E MEIOS DE LEVANTAMENTO DE PROBLEMAS E DE ARTICULAÇÃO. ENTRE OS PROFISSIONAIS DA EQUIPE, OS AGENTES SÃO IDENTIFICADOS COMO AQUELES DE MAIOR INICIATIVA E CAPACIDADE DE MOBILIZAÇÃO; ORGANIZAÇÕES SOCIAIS TAMBÉM AGLUTINAM E INFLUENCIAM O MOVIMENTO SOCIAL:

Hoje o esgoto ainda corre a céu aberto, então nós fazemos cartas, mandamos para a SABESP. Não tinha luz, não tinha água encanada, nós conseguimos água encanada... isso nós fazemos para a comunidade (Equipe 1, Agente 1)

Quem coordena tudo são os funcionários do QUALIS... nós aqui de dentro é que resolvemos fazer tudo (Equipe 1, Agente 1)

Cada 3 meses, cada 6 meses, a gente tem um encontro com o pessoal da (entidade responsável pelo QUALIS na região, onde eles nos orientam de como levar o nosso trabalho e para a gente fazer uma avaliação de como está. Essa avaliação é sempre feita pela nossa entidade... quanto às outras, eu não tenho informação. (Equipe 1, Agente 3)

\subsection{Interação com a organização do trabalho institucional}


Além da identificação das atividades-fim, uma outra forma de apreensão do processo de trabalho dos agentes é através dos instrumentos utilizados na sua ação, entre os quais destacam-se: a educação e a comunicação; o registro e a quantificação; o saber técnico e a experiência. Outro conjunto de atividades de organização do trabalho institucional, como a supervisão, as relações hierárquicas, os espaços de reunião, o planejamento de atividades e as normatizações não serão aqui detalhados.

\section{A Comunicação e a Educação. A conversa e a prescrição}

A comunicação é instrumento essencial do trabalho do agente de saúde, podendo ser realizada no contato individual e coletivo. Essa é uma característica avaliada desde a seleção dos agentes de saúde e apontada como conteúdo importante do treinamento:

Algum problema que eu tive para resolver no meu trabalho ? Assim problema de saúde não teve tanto. Teve mais problema de comunicação, porque a gente precisa saber se comunicar com a pessoa. (Equipe 3, Agente 5)

Não gosto de falar assim, no meio de gente, não gosto não... mas eu adoro falar um por um, eu adoro sabe... a gente bate nas casas e orienta essas pessoas... (Equipe 2, Agente 2)

Na comunicação com a clientela utilizam-se de diversas estratégias: usar um jeitinho, sensibilizar, propor uma experiência, dar um exemplo, pedir um depoimento. Mas se o objetivo, por exemplo, de alcançar maior aderência do usuário ao cuidado (vacinação, uso de medicação, comparecimento ao atendimento agendado) pode ser alcançado, na maior parte das situações, ele não se dá através de uma prescrição:

(Para o caso de um hipertenso "resistente") Continuo pegando no pé, continuo orientando, com calma, com jeitinho. Porque se você for falar: "Ah, mas você tem que ir", a pessoa se revolta e não vai. Então a gente vai com muita calma, citando exemplos: "Olha, você precisa participar (da caminhada) para você ver. Nós tivemos casos assim, assim, melhorou bastante. Vai um dia para você fazer uma experiência". Então a gente sempre continua insistindo. A gente não desiste, não. (Equipe 1, Agente 2)

Para chamar a atenção do cliente o agente muitas vezes lança mão da autoridade do médico e da estratégia de ameaça: 
Quando eles não seguem a gente vai lá e orienta, e fala que a Doutora está brava porque isso, porque aquilo, porque não está fazendo a dieta direitinho. Tem pessoas que precisam de puxão de orelha, ai a gente vai e dá o recado. (Equipe 2, Agente 2)

Eu acho que (a atividade mais importante) é nós entrarmos de casa em casa e fazermos as orientações... como a pessoa está se sentindo, se ela tomou medicação, se não tomou... a gente faz orientação, se ela tem consulta marcada, se as vacinas estão em dia. (Equipe 1, Agente 1)

$\mathrm{O}$ entendimento da aderência e as formas de se lidar com as pessoas consideradas pela equipe como "não aderentes/ resistentes/ teimosos" são ilustrativos da concepção de educação e comunicação vigentes no PSF:

Às vezes as pessoas são resistentes mesmo, o hipertenso, num quer vir mesmo (para atendimento)... acha que não precisa. (Equipe 1, Agente 4)

Às vezes tem alguns teimosos para tomar medicação, para seguir orientação, então em cima destes teimosos que a gente trabalha mais. (Equipe 1, Agente 3)

A DIFICULDADE DE CUMPRIR O TRATAMENTO INDICADO PELO MÉDICO É ENTENDIDA COMO RESISTÊNCIA DAS PESSOAS. O CUIDADO DOS HIPERTENSOS LEVANTA O PROBLEMA DA ADERÊNCIA. O CONTROLE DO USO DA MEDICAÇÃO E SEGUIMENTO DE DIETA E ATIVIDADE FÍSICA, O COMPARECIMENTO ÀS CONSULTAS

E A MEDIdA de PRESSÃO ARTERIAL, EM CASA, PELO AUXILIAR DE ENFERMAGEM, REPRESENTAM UM GRANDE INVESTIMENTO DA

\section{EQUIPE:}

Esse controle a gente mantém ali no pé da letra mesmo. Às vezes, o pessoal fica chateado, diz: "Nossa, você está sempre pegando no pé", mas aí a gente explica a importância, porque a gente está ali. (Equipe 1, Agente 2)

São dois anos que eu trabalho em cima deles... o rapaz (tetraplégico) está irredutível... e a mãe dele é uma pessoa hipertensa que não aceita tratamento. Ela diz: "Eu estou com Deus e nada vai me acontecer". A atitude que a gente toma é fazer visita, tentar conscientizar ela... continuadamente... A gente não desiste, e continua insistindo... Agora, depois de dois anos, o rapaz está começando a se interessar por fisioterapia... é um trabalho que está começando a dar resultado. (Equipe 2, Agente 1)

Para "vencer" o agente usa da persistência, muitas vezes traduzida na visita diária, e de um certo "jeito", em um jogo corpo a corpo. Se não tem sucesso, pede reforço da equipe:

Naquela casa de 23 pessoas, eu tenho que ir diariamente para ver se estão tomando remédio, acompanhar realmente se eles estão tomando... teve um caso de abandono de tratamento, então eu tenho que ir todo dia. (Equipe 4, Agente 2) 
A gente tem que sensibilizar mesmo, tem que ir com jeitinho, com jogo de cintura, $e$ sensibilizar. (Equipe 1, Agente 4)

Aquelas pessoas resistentes em fazer o Papanicolau, você tenta convencer na primeira visita, você vai na segunda e tenta convencer, mas também você não pode chegar só falando que senão enche. Nesse caso do resistente a gente passa para a enfermeira, para o auxiliar, fala: vamos comigo, quem sabe você, com jeitinho, você consegue mais do que eu... (Equipe 1, Agente 4)

Analisando os padrões de atividades educativas registradas nos Cadernos de Observação dos Trabalhos dos Agentes de Saúde (Quadro 4.9), destacam-se as ações do tipo mais impositivo, chegando às vezes a um cunho autoritário, em relação a um padrão mais dialogado, restringindo-se as possibilidades de conversa com exposição e confrontação de valores e de conversa com negociação de alternativas. Para ilustração desse tipo de interação, apresenta-se a transcrição da seguinte visita domiciliar:

Visita domiciliar (Agente de saúde 2, Equipe 1)

AGENTE: COMO ESTÁ A VACINA DAS CRIANÇAS?

MULHER: ESTÃO EM DIA. A MINHA ESTÁ ATRASADA.

AGENTE: TEM QUE TOMAR!

MULHER: QUANDO A GENTE ESTÁ GRÁVIDA FAZ TUDO CERTINHO... QUANDO NASCE...

AGENTE: PASSOU EM CONSULTA DEPOIS DO PARTO?

MULHER: $\quad$ NÃO. TINHA CONSULTA, MAS PERDI.

AGENTE: A NENÊ ESTÁ BEM? QUANTO TEMPO?

MULHER: ESTÁ COM QUATRO MESES.

AGENTE: $\quad$ ESTÁ DANDO MAMADEIRA OU PEITO?

MULHER: MAMADEIRA E PEITO.

AGENTE: SEU MARIDO JÁ CONSEGUIU SERVIÇO?

MULHER: JA, GRAÇAS A DEUS.

AGENTE: VOCÊ ESTÁ PASSANDO A NENÊ TODO MÊS NO POSTO?

MULHER: ESTOU.

AGENTE: (PARA A OUTRA CRIANÇA) E ESTES DENTES: CADÊ?

MULHER: CAIU TUDO E ESTÁ NASCENDO TORTO. TEM DENTISTA NO

POSTO?

AGENTE: NÃO, SÓ NO POSTO DA REGIONAL DE .... NO SEU QUARTO

NÃO TEM JANELA? 
MULHER: NÃO, SÓ VENTILADOR

AGENTE: DEIXA SEMPRE A PORTA ABERTA PARA VENTILAR.

(A AGENTE SE DESPEDE)

COMO SE PÔDE ACOMPANHAR, O AGENTE DE SAÚDE NÃO DISCUTE COMO VAI A FAMÍLIA COM A CRIANÇA NOVA, ALIMENTAÇÃO DA CRIANÇA, PLANEJAMENTO FAMILIAR, ENTRE OUTROS ASPECTOS QUE PROPICIARIAM OPORTUNIDADES PARA ORIENTAÇÕES LIMITANDOSE A UMA COLETA DE INFORMAÇÃO PARA PREENCHIMENTO DE DADOS DA SUA PLANILHA E A ORIENTAÇÕES NORMATIZADAS. NESTE TIPO DE SITUAÇÃO, BASTANTE COMUM NAS OBSERVAÇÕES, LEVANTA-SE A HIPÓTESE DE QUE A VISITA, EM VEZ DE ATIVIDADE-FIM, ADQUIRE CARÁTER DE ATIVIDADE-MEIO, DESLOCADA PELO AFÃ DE PRESTAR CONTAS DE UM NÚMERO DETERMINADO DE VISITAS MENSAIS AS FAMÍLIAS

Quadro 4.9 Distribuição das atividades de 8 agentes comunitários de saúde do QUALIS conforme padrão de atividade educativa

\begin{tabular}{|c|l|l|l|l|l|l|l|l|}
\hline ATIVIDADES & $\begin{array}{c}\text { Equipe 1 } \\
\text { Agente 4 }\end{array}$ & $\begin{array}{c}\text { Equipe 1 } \\
\text { Agente 2 }\end{array}$ & $\begin{array}{c}\text { Equipe 2 } \\
\text { Agente 1 }\end{array}$ & $\begin{array}{c}\text { Equipe 2 } \\
\text { Agente 2 }\end{array}$ & $\begin{array}{l}\text { Equipe 3 } \\
\text { Agente 3 }\end{array}$ & $\begin{array}{c}\text { Equipe 3 } \\
\text { Agente 5 }\end{array}$ & $\begin{array}{c}\text { Equipe 4 } \\
\text { Agente 1 }\end{array}$ & $\begin{array}{c}\text { Equipe 4 } \\
\text { Agente 2 }\end{array}$ \\
\hline $\begin{array}{c}\text { ATIVIDADE } \\
\text { EDUCATIVA }\end{array}$ & & & & & & & & \\
\hline $\begin{array}{c}\text { Padrão mais } \\
\text { prescritivo }\end{array}$ & 15 & 20 & 26 & 27 & 20 & 19 & 26 & 12 \\
\hline $\begin{array}{c}\text { Padrão } \\
\text { mais dialogado }\end{array}$ & 01 & 08 & 03 & & 04 & 03 & 05 & 01 \\
\hline
\end{tabular}


Portanto, o projeto de "cuidar" — de interessar-se e conversar com a pessoa, estimular iniciativas, ouvir o que a pessoa tem para dizer, tirar dúvidas — não encontra espaço ou forma de expressão, na maior parte do trabalho do agente.

A falta do indivíduo a atividades agendadas é entendida como uma desvalorização do trabalho (e empenho) da equipe. A falta também é parcialmente atribuída ao trabalho do agente na visita aos domicílios: é o seu cliente que não veio:

(Quando uma gestante falta em consulta de pré-natal) A gente vai atrás para não deixar ela solta. (Equipe 1, Agente 2)

\section{Registro e Quantificação}

O registro é atividade significativa do trabalho dos agentes, que se não representa muitas horas diárias de trabalho, é considerado não só difícil, mas cuja finalidade não parece clara para eles:

Nós anotamos tudo. Cada tipo de doença, hipertenso, diabético, cada uma tem uma ficha. Quando tem muita coisa para escrever, nós temos um caderno à parte. Tudo que a gente vai fazer na visita, a gente anota no caderno, numa planilha, numa ficha que eles chamam de Ficha B. Tudo está anotado. Tem que anotar tudo... (Equipe 4, Agente 2)

Eu achava que não tinha que preencher tanto papel, tanta burocracia que a gente dá conta. Tem que prestar conta da visita que a gente faz por dia, de um monte de coisa... Nos primeiros meses eu achei difícil, não pelo trabalho na área, mas pela burocracia... cheguei a pensar que eu ia desistir. (Equipe 1, Agente 1)

A dificuldade maior que eu tenho encontrado é em relação a todos estes papéis que eu tenho que preencher, relatórios... (isso) mexe com a nossa mente... isso é um pouco demorado. É dados... quando pediam dados... antes não tinha planilha, ... a gente tinha que estar levantando prontuário por prontuário...Agora a gente já está fazendo tudo, o único dado que a gente tem que estar sempre atualizando é o de gestante e de menor de um ano, porque está sempre mudando. (Equipe 1, Agente 2)

Antes fazia mais levantamento, qualquer coisa fazia levantamento. Hoje está mais calmo, mas antes fazia muito levantamento. $O$ último foi sobre os desempregados. Então está sempre vendo a necessidade do povo para estar trabalhando em cima . (Equipe 2, Agente 2)

Quem usa mais as anotações é a Doutora, mas se a enfermeira quiser ter acesso também pode, porque é uma informação do paciente. A anotação fica no posto, dentro do prontuário. (Equipe 2, Agente 2) 
Há uma expectativa de racionalidade no trabalho, na qual um problema importante é representado pela informações repetidas:

O que a gente não gosta mesmo, a gente se debate sempre contra eles, é ter vários papéis dizendo a mesma coisa... Muita burocracia. (Equipe 2, Agente 1)

Desde a implantação do PSF, os registros sofreram modificações e ainda buscam uma forma de articular as informações dos diversos momentos de atenção:

Os papéis foram mudando; era uma forma, depois outra, depois outra. Hoje está se estudando uma forma de pôr o relatório dentro do prontuário médico. (Equipe 2, Agente 1)

Das visitas, é registrado o número realizado para cada família; se alguém do domicílio está incluído em um dos grupos de risco priorizados pelo PSF, não se registra o conteúdo do trabalho. Portanto, o registro está voltado para a coleta continuada de dados e não para o trabalho de orientação e a conversa, que os agentes valorizam na entrevista:

(O registro)... é um trabalho de escrita que passa para outra pessoa para ver o a produção da gente... mas fica um trabalho pessoal que não está na escrita... fica só registrada a quantidade e não a qualidade, que não se registra. (Equipe 2, Agente 2)

O nosso trabalho é muito mais... tem muito mais do que ...papéis... A gente anota mais por obrigação mesmo... e a gente tem brigado contra isso. As anotações são passadas depois para a enfermeira, onde ela faz a avaliação do nosso trabalho. (Equipe 2, Agente 1)

\section{Técnica e Experiência como instrumentos de trabalho}

Os agentes constatam uma insuficiência da técnica do saber, em relação ao seu objeto de trabalho:

Tem muitas situações que a gente passa que não está escrito, que não apareceu no treinamento, mas na hora a gente tem que ter jogo de cintura... Quando chega a hora do vamos ver, é mais da pessoa, porque eu ajo de um jeito, outra pessoa já age de outro modo. Tem sempre que ter um raciocínio rápido e acho que vai muito de pessoa para pessoa... Quando fica assim muito grave (a situação) a gente fala para a enfermeira e aí junto se vê o que se pode fazer (Equipe 2, Agente 2)

\section{O QUE ESCAPA AO TREINAMENTO É SUPRIDO COM A EXPERIÊNCIA DE VIDA DO AGENTE:}

(Caso de surto psicótico) Eu tentei ajudar da melhor maneira, do meu jeito... Eu recorri à unidade. Com muita paciência, com muito jeitinho, eu acabei chegando até o Posto com ela... (Equipe 1, Agente 2) 
O agente de saúde associa diferentes meios e recursos disponíveis, de "dicas" nutricionais ao sobrenatural:

A orientação sobre alimentação - essa é uma das questões assim mais delicadas porque, como eu já falei, essa região é muito pobre, o desemprego é muito... e às vezes a gente orienta a pessoa para estar tentando fazer uma alimentação à base de frutas $e$ legumes, sendo que isso se torna um pouquinho dificil em alguns casos. Mas a gente tem conseguido bastante... Por exemplo, às vezes a gente chega numa familia e a mãe fala assim: "Ah, mas meu marido está desempregado, eu vou comprar de que jeito?". Mas ai tem outras alternativas. A gente conversa com ela, explica para estar colocando talo de verdura na sopa ou no próprio caldinho de feijão. A gente trabalha com o que a gente tem - com a realidade. (Equipe 1, Agente 2).

Quando a técnica é insuficiente para dar conta da complexidade da situação, recorre-se a outras estratégias, entre as quais está Deus:

Muitas vezes a gente chega em uma visita e encontra uma situação que a gente fica pensando assim: "Ih, meu Deus, o que é que eu vou falar com esta famillia? Então, por mais que você seja treinado, você vai encontrar este tipo de coisa. E acaba tendo uma solução. Porque, em primeiro lugar, a gente tem que ter Deus conosco. Se a gente tem Deus conosco, a gente consegue muita coisa. (Equipe 1, Agente 2)

Para um problema que diz respeito à organização do sistema de saúde e, mais amplamente, à saúde como direito de cidadania e como qualidade de vida, como o acesso a serviço de referência mais especializado, o agente também orienta baseado na sua experiência, mas não politiza o tema (para o cliente, a equipe e o entrevistador), como pode ser constatado nos seguintes relatos:

A saúde hoje em dia está uma coisa calamitosa, sabe. Por exemplo, a gestante vem fazer o pré-natal na unidade, a gente dá toda a informação para ela... Aí chega na hora dela ir para uma referência, para ter o bebê dela... ela fica daqui para lá, daqui para lá, vai para não sei onde, vai e volta...Então muitas vezes, a gente ali para aquela paciente, com a experiência que a gente tem hoje, a gente já conhece alguns locais que dão algum atendimento mais adequado... eu já evito dela ficar daqui para lá. Eu falo para ela: "Vai ali". (Equipe 2, Agente 1)

Educação continuada tem muito panfleto... e a gente está procurando estudar bastante... principalmente patologia. Uma coisa que não está escrito em lugar nenhum é o lado humano do trabalho. Ele é da gente mesmo, está escrito dentro do coração de cada um. (Equipe 2, Agente 1)

\subsection{Caracterização do perfil ocupacional-social do Agente Comunitário de Saúde do QUALIS}

Na opinião do agente, este é o significado do seu trabalho para a população: $O$ agente de saúde é o principal (na equipe) porque ele conhece cada família. É tipo assim, se é uma família que o médico chega lá e não pode falar tal coisa, a gente vai e 
já avisa, essa família é assim, assim; quando chegar, chega com jeitinho. Porque às vezes o vizinho não sabe o que a pessoa passa, mas a gente sabe, porque eles confiam, desabafam tudo.. (Equipe 1, Agente 4)

Eles têm um apoio, eles acham um apoio, porque você passa confiança para eles... eles se abrem, eles te falam, eles confiam em você. (Equipe 1, Agente 1)

Eles falam que gostam do trabalho daqui porque as pessoas, eles falam assim: "As meninas do Posto se preocupam com a gente"; eles usam muito esta frase: "As meninas do Posto se preocupam com a gente... a gente nunca teve tratamento assim". Quando eles falam, eles não falam só do agente. Eles falam "as meninas do Posto", "o pessoal do Posto". (Equipe 1, Agente 2)

Sempre que as pessoas necessitam de alguma coisa, elas sabem onde contar. Não só com a doença, não. As pessoas aqui nos procuram... sempre tem alguém aqui para dar atenção, para conversar. É como a gente fala: nem sempre as coisas dependem só do médico, não é? (Equipe 1, Agente 3)

Como pôde ser verificado nesses depoimentos, os agentes pensam que, para a população, sobressai o seu papel de intermediador da relação da família com o mundo exterior e no contato com a equipe de saúde, especialmente, com o médico. Por outro lado, aparece a importância atribuída pela população ao cuidado: conhecer de forma mais íntima, preocupar-se com o outro, dar apoio, poder contar em momentos de necessidade ou sofrimento. No entanto, as atividades de suporte social não são privilegiadas no trabalho do agente e nem recebem destaque nas reuniões de equipe.

Entre as ações que os agentes consideram mais importantes para a saúde das famílias, eles são diretamente responsáveis por uma (a visita) e participam em muitas unidades de outra (o grupo educativo):

Em primeiro lugar, (o que considero mais importante) é que eu vá saber nas casas os problemas deles; em segundo lugar, que eles estejam passando em consulta; em terceiro, que estejam participando dos grupos, porque nos grupos se tem falado de muitas coisas (importantes) para a saúde deles. (Equipe 2, Agente 2)

Acho que a importância do nosso trabalho está aí na mudança de hábito... mudar mesmo a conscientização. (Equipe 1, Agente 3)

NOTE-SE QUE HÁ UMA TENSÃO ENTRE AS DIFERENTES

FACETAS DO TRABALHO DO AGENTE. CONTROLAR RISCOS ATRAVÉS DA VERIFICAÇÃO DO CUMPRIMENTO DE CRONOGRAMAS 


\section{ASSISTENCIAIS (DE CONSULTAS, VACINAS E SCREENINGS) E DA CONFERÊNCIA DO USO DA MEDICAÇÃO E SEGUIMENTO DE DIETA E DE ATIVIDADE FÍSICA, OCUPA GRANDE PARTE DOS OBJETIVOS DE VISITA E DO REGISTRO MINUCIOSO DO TRABALHO. A ATIVIDADE DE ORIENTAR E, ESPECIALMENTE, DE CONVERSAR SOBRE A FAMÍLIA E A COMUNIDADE, OCUPAM UM ESPAÇO SECUNDÁRIO NO SEU}

TRABALHO.

Apesar de os agentes valorizarem, no seu trabalho, a importância das orientações, pensam que a população valoriza neles traços de solidariedade institucionalizada. Acabam tratando o cliente como parente e tomando para si o seu problema:

Nós tratamos, tanto o auxiliar, como o enfermeiro, como o agente, nós tratamos eles como se eles fossem da família da gente... como se fosse nosso pai, nossa mãe, nosso filho... quanto a esse ponto, eu acho que nós somos bem humanos. (Equipe 1, Agente 1)

Como a gente diz "problema de casa deixa em casa", "problema da unidade deixa na unidade", mas tem problema que a gente não consegue deixar... atendimento para doente mental só tem consulta em 3 meses, gestante não tem vaga em hospital... a gente acaba levando... No final de semana, elas procuram a gente: "Olha, fui em um tal lugar e não consegui vaga, fui em outro não consegui... às vezes a gente acaba até saindo com elas, andando com elas para ver se consegue... porque a falta de vaga (em maternidade) está demais. (Equipe1, Agente 3)

A visita domiciliar, entretanto, não deixa de ser uma ingerência na casa e nos afazeres domésticos:

Na maioria das visitas, nós somos atendidas pelas donas de casa... e ela está preocupada se é hora do almoço para fazer o almoço, se é para lavar roupa, se é para passar roupa... e, muitas vezes, ela não sabe que importância aqueles 10-15 minutos tem para ela. (Equipe 2, Agente 1)

\section{Identidade do Agente Comunitário de Saúde}

A partir das entrevistas foram levantados os seguintes aspectos que conformam a identidade do agente de saúde: características necessárias ao agente; como se sente no trabalho; e sonhos e planos para o futuro. Se a primeira refere-se a um plano mais objetivado do perfil preconizado para o agente, as duas últimas dizem respeito a dimensões mais subjetivas.

Nos Quadros 4.10; 4.11; 4.12; 4.13 pode-se observar que os agentes consideram como características necessárias ao agente atribuições de caráter (coragem, flexibilidade, solidariedade, respeito para como o outro, discrição), 
disposição para aprendizado e troca de conhecimentos, habilidades para comunicação, condições físicas e mentais.

Quadro 4.10. Caracterização de 4 agentes comunitários de saúde da Equipe 1 segundo sua opinião sobre características necessárias ao agente de saúde, como se sente trabalhando como agente, planos e sonhos para o futuro

\begin{tabular}{|l|l|c|c|c|}
\hline $\begin{array}{l}\text { CARACTERÍSTICAS } \\
\text { DO AGENTE }\end{array}$ & AGENTE 1 & AGENTE 2 & AGENTE 3 & AGENTE 4 \\
\hline $\begin{array}{l}\text { Características necessárias } \\
\text { ao agente comunitário de } \\
\text { saúde }\end{array}$ & $\begin{array}{c}\text { Ter coragem, } \\
\text { gostar do próximo }\end{array}$ & $\begin{array}{c}\text { Aprender no } \\
\text { treinamento, nas } \\
\text { reuniões, aprender } \\
\text { com as pessoas, } \\
\text { ajudar as pessoas }\end{array}$ & $\begin{array}{c}\text { Procurar ajudar o } \\
\text { ser humano, } \\
\text { encarar de perto o } \\
\text { problema das } \\
\text { pessoas, humildade } \\
\text { p/ ver as pessoas } \\
\text { como elas são }\end{array}$ & $\begin{array}{c}\text { Ter "jeitinho", } \\
\text { jogo de cintura } \\
\text { para falar com as } \\
\text { pessoas, tem que } \\
\text { saber entender * }\end{array}$ \\
\hline $\begin{array}{c}\text { Como se sente } \\
\text { trabalhando como agente } \\
\text { comunitário de saúde }\end{array}$ & Prestativa & $\begin{array}{c}\text { Acha agradável; } \\
\text { sente-se informado } \\
\text { e informante }\end{array}$ & $\begin{array}{c}\text { Deixa eventual } \\
\text { crítica às pessoas e } \\
\text { procura ajudar }\end{array}$ & Sente-se útil \\
\hline $\begin{array}{l}\text { Planos e sonhos para o } \\
\text { futuro }\end{array}$ & $\begin{array}{c}\text { Ser auxiliar de } \\
\text { enfermagem }\end{array}$ & $\begin{array}{c}\text { Ser psicóloga ou } \\
\text { assistente social }\end{array}$ & $\begin{array}{c}\text { Estudar p/ ter mais } \\
\text { conhecimento p/ } \\
\text { fazer melhor seu } \\
\text { trabalho p/ } \\
\text { comunidade }\end{array}$ & $\begin{array}{c}\text { Apaixonada pelo } \\
\text { trabalho, vontade } \\
\text { de fazer curso de } \\
\text { auxiliar de } \\
\text { enfermagem }\end{array}$ \\
\hline
\end{tabular}


Quadro 4.11. Caracterização de 4 agentes comunitários de saúde da Equipe 2 segundo sua opinião sobre características necessárias ao agente de saúde, como se sente trabalhando como agente, planos e sonhos para o futuro

\begin{tabular}{|c|c|c|c|c|}
\hline $\begin{array}{l}\text { CARACTERÍSTICA } \\
\text { S DO AGENTE } \\
\end{array}$ & AGENTE 1 & AGENTE 2 & AGENTE 3 & AGENTE 4 \\
\hline $\begin{array}{l}\text { Características } \\
\text { necessárias ao agente } \\
\text { comunitário de saúde }\end{array}$ & $\begin{array}{c}\text { Ter espírito solidário } \\
\text { e afinidade com a } \\
\text { comunidade }\end{array}$ & $\begin{array}{l}\text { Capacidade de trocar } \\
\text { conhecimento, } \\
\text { experiências e } \\
\text { sentimentos; trabalhar } \\
\text { com pessoas e não pelo } \\
\text { salário }\end{array}$ & $\begin{array}{l}\text { Boa saúde física e } \\
\text { mental; tem que lidar } \\
\text { com o ser humano, o } \\
\text { que repercute no } \\
\text { emocional do agente; } \\
\text { preparado/aberto para } \\
\text { "o que der e vier" }\end{array}$ & $\begin{array}{l}\text { Gostar da } \\
\text { comunidade; tentar } \\
\text { resolver problemas; } \\
\text { respeitar a vontade das } \\
\text { pessoas }\end{array}$ \\
\hline $\begin{array}{l}\text { Como se sente } \\
\text { trabalhando como } \\
\text { agente comunitário } \\
\text { de saúde }\end{array}$ & Gratificante & $\begin{array}{l}\text { Gratificante; gosta da } \\
\text { singularidade das casas } \\
\text { e das pessoas }\end{array}$ & $\begin{array}{l}\text { Trabalho desgastante, } \\
\text { mas gosta do que faz }\end{array}$ & $\begin{array}{l}\text { Gratificante trabalhar } \\
\text { em equipe; sensação } \\
\text { do trabalho ficar } \\
\text { sempre a desejar pelo } \\
\text { número grande de } \\
\text { famílias sob sua } \\
\text { responsabilidade }\end{array}$ \\
\hline $\begin{array}{l}\text { Planos e sonhos para } \\
\text { o futuro }\end{array}$ & $\begin{array}{l}\text { Acabar o curso de } \\
\text { auxiliar } \\
\text { enfermagem, mas } \\
\text { não quer perder o } \\
\text { seu perfil de } \\
\text { solidariedade }\end{array}$ & $\begin{array}{l}\text { Horta comunitária (tem } \\
\text { o terreno; falta água } \\
\text { gratuita Sabesp); creche }\end{array}$ & $\begin{array}{c}\text { Formar-se como auxiliar } \\
\text { de enfermagem e } \\
\text { continuar a trabalhar } \\
\text { com prevenção }\end{array}$ & $\begin{array}{c}\text { Gostaria de ser } \\
\text { capacitada a fazer } \\
\text { algumas funções de } \\
\text { auxiliar de } \\
\text { enfermagem para seu } \\
\text { trabalho ser mais } \\
\text { resolutivo } \\
\end{array}$ \\
\hline
\end{tabular}


Quadro 4.12. Caracterização de 5 agentes comunitários de saúde da Equipe 3 segundo sua opinião sobre características necessárias ao agente de saúde, como se sente trabalhando como agente, planos e sonhos para o futuro

\begin{tabular}{|c|c|c|c|c|c|}
\hline $\begin{array}{l}\text { CARACTERI } \\
\text { STICAS DO } \\
\text { AGENTE } \\
\end{array}$ & AGENTE 1 & AGENTE 2 & AGENTE 3 & AGENTE 4 & AGENTE 5 \\
\hline $\begin{array}{l}\text { Característica } \\
\text { s necessárias } \\
\text { ao agente } \\
\text { comunitário } \\
\text { de saúde }\end{array}$ & $\begin{array}{c}\text { Ter fé e } \\
\text { coragem, não } \\
\text { ter medo de } \\
\text { andar, medo do } \\
\text { sol e da chuva. } \\
\text { Gostar do que } \\
\text { faz }\end{array}$ & $\begin{array}{l}\text { Conversar } \\
\text { bastante; ser } \\
\text { discreto - não } \\
\text { pode falar da } \\
\text { vida alheia; } \\
\text { enfrentar sol, } \\
\text { chuva e "tudo" }\end{array}$ & $\begin{array}{c}\text { Humildade, } \\
\text { profissionalism } \\
\text { o }\end{array}$ & $\begin{array}{c}\text { Gostar das } \\
\text { pessoas/respeit } \\
\text { o pelo próximo; } \\
\text { paciência, } \\
\text { compreensão; } \\
\text { saber ouvir; ser } \\
\text { objetivo no } \\
\text { falar }\end{array}$ & $\begin{array}{l}\text { Ser aberto; } \\
\text { conversar com } \\
\text { as pessoas; Ter } \\
\text { paciência } \\
\text { porque as } \\
\text { pessoas são } \\
\text { exigentes. Ser } \\
\text { esperto/intelige } \\
\text { nte porque às } \\
\text { vezes o } \\
\text { trabalho é } \\
\text { complexo }\end{array}$ \\
\hline $\begin{array}{l}\text { Como se sente } \\
\text { trabalhando } \\
\text { como agente } \\
\text { comunitário } \\
\text { de saúde }\end{array}$ & $\begin{array}{l}\text { "Amo o } \\
\text { trabalho, mas já } \\
\text { chorei muito" }\end{array}$ & $\begin{array}{l}\text { Gosta muito do } \\
\text { trabalho; } \\
\text { percebeu os } \\
\text { sintomas de } \\
\text { diabetes do pai; } \\
\text { orienta/"pega } \\
\text { no pé" da mãe } \\
\text { hipertensa }\end{array}$ & $\begin{array}{c}\text { Minha família } \\
\text { acha que eu } \\
\text { tenho o "dom" } \\
\text { p/ ser agente de } \\
\text { saúde }\end{array}$ & $\begin{array}{l}\text { Tem situações } \\
\text { em que a única } \\
\text { forma de } \\
\text { contribuir é } \\
\text { com palavras }\end{array}$ & $\begin{array}{l}\text { Ser homem e } \\
\text { ser jovem } \\
\text { atrapalha o } \\
\text { trabalho do } \\
\text { agente porque } \\
\text { as pessoas } \\
\text { acham que não } \\
\text { é responsável }\end{array}$ \\
\hline $\begin{array}{l}\text { Planos e } \\
\text { sonhos para o } \\
\text { futuro }\end{array}$ & $\begin{array}{c}\text { Voltar a } \\
\text { estudar; fazer } \\
\text { Escola de } \\
\text { Enfermagem; } \\
\text { trabalhar na } \\
\text { Polícia Militar } \\
\text { como } \\
\text { enfermeira }\end{array}$ & $\begin{array}{c}\text { Quer ser } \\
\text { enfermeira: “eu } \\
\text { adoro curativo, } \\
\text { ver alguém } \\
\text { dando injeção". } \\
\text { Acha que } \\
\text { cuidar do ser } \\
\text { humano é } \\
\text { muito legal; } \\
\text { antes só lidava } \\
\text { com números e } \\
\text { contas } \\
\end{array}$ & $\begin{array}{l}\text { Casa própria; } \\
\text { bom futuro p/ } \\
\text { os filhos } \\
\text { adolescentes }\end{array}$ & $\begin{array}{l}\text { Lecionar } \mathrm{p} / \\
\text { adultos e } \\
\text { adolescentes; } \\
\text { ser cabo } \\
\text { eleitoral }\end{array}$ & $\begin{array}{c}\text { Continuar } \\
\text { trabalhando } \\
\text { como agente. } \\
\text { Expectativa de } \\
\text { capacitação } \\
\text { para } \\
\text { procedimentos } \\
\text { como curativo } \\
\text { e medida de } \\
\text { pressão arterial }\end{array}$ \\
\hline
\end{tabular}


Quadro 4.13. Caracterização de 4 agentes comunitários de saúde da Equipe 4 segundo sua opinião sobre características necessárias ao agente de saúde, como se sente trabalhando como agente, planos e sonhos para o futuro

\begin{tabular}{|c|c|c|c|c|}
\hline $\begin{array}{l}\text { CARACTERÍSTICAS } \\
\text { DO AGENTE }\end{array}$ & AGENTE 1 & AGENTE 2 & AGENTE 3 & AGENTE 4 \\
\hline $\begin{array}{l}\text { Características } \\
\text { necessárias ao agente } \\
\text { comunitário de saúde }\end{array}$ & $\begin{array}{l}\text { Ter vocação de } \\
\text { ajudar as pessoas; } \\
\text { ter coragem de } \\
\text { lidar com doente, } \\
\text { com gente } \\
\text { necessitada. Ser } \\
\text { um lutador }\end{array}$ & $\begin{array}{l}\text { Tem que gostar de } \\
\text { trabalhar na área } \\
\text { de saúde; tem que } \\
\text { ser persistente; } \\
\text { precisa ser } \\
\text { humanizado }\end{array}$ & $\begin{array}{l}\text { Tem que gostar do } \\
\text { que faz; ser } \\
\text { sensível; saber } \\
\text { conversar }\end{array}$ & $\begin{array}{l}\text { Ser calmo; saber } \\
\text { ouvir; Ter } \\
\text { disponibilidade de } \\
\text { tempo além do } \\
\text { horário da unidade } \\
\text { de saúde }\end{array}$ \\
\hline $\begin{array}{c}\text { Como se sente } \\
\text { trabalhando como } \\
\text { agente comunitário de } \\
\text { saúde }\end{array}$ & $\begin{array}{c}\text { Não fica } \\
\text { sossegada / fica } \\
\text { nervosa se não } \\
\text { consegue resolver } \\
\text { um problema } \\
\text { Toda vida ajudou } \\
\text { as pessoas e agora } \\
\text { ganha um } \\
\text { pouquinho pelo } \\
\text { trabalho }\end{array}$ & $\begin{array}{l}\text { Tenta ao máximo } \\
\text { resolver o } \\
\text { problema das } \\
\text { pessoas }\end{array}$ & $\begin{array}{l}\text { Busca no que for } \\
\text { possível trazer } \\
\text { solução para o } \\
\text { paciente; sente-se } \\
\text { em geral bem- } \\
\text { vinda onde quer } \\
\text { que vá; acha } \\
\text { gratificante poder } \\
\text { fazer alguma coisa } \\
\text { pelo vizinho }\end{array}$ & $\begin{array}{l}\text { É compensador } \\
\text { (se doar, se } \\
\text { preocupar com o } \\
\text { próximo; poder } \\
\text { dar atenção para } \\
\text { alguém; conseguir } \\
\text { resolver problema } \\
\text { das pessoas) }\end{array}$ \\
\hline $\begin{array}{l}\text { Planos e sonhos para o } \\
\text { futuro }\end{array}$ & Sem informação & $\begin{array}{l}\text { Sonho: mais verba } \\
\text { pública para saúde } \\
\text { e educação }\end{array}$ & $\begin{array}{c}\text { Fazer curso de } \\
\text { auxiliar de } \\
\text { enfermagem para } \\
\text { sendo agente } \\
\text { comunitário, } \\
\text { poder ter mais } \\
\text { conhecimento } \\
\text { para auxiliar as } \\
\text { pessoas }\end{array}$ & $\begin{array}{l}\text { Fazer Faculdade } \\
\text { de Administração }\end{array}$ \\
\hline
\end{tabular}

$\mathrm{Na}$ maioria dos depoimentos encontram-se agentes satisfeitos com o trabalho, quer pela sensação de gratificação pela ajuda ao outro e de resolubilidade, quer pela ampliação do conhecimento na área da saúde e reconhecimento da população por esse conhecimento. No entanto, a satisfação não descarta a vivência de situações de angústia e sofrimento.

Em relação aos planos para o futuro, chama a atenção a perspectiva de continuidade de estudos, com destaque para o campo da enfermagem. Aparecem também em algumas entrevistas a área de psicologia e assistência social, dois outros campos que lidam com necessidades da população. O estudo representa tanto uma oportunidade de aprofundar conhecimento, mantendo o trabalho de agente, como de profissionalização, especialmente como auxiliar de enfermagem. 
Identifica-se, ainda, uma série de opiniões que conformam a identidade do sujeito-agente por referência aos outros sujeitos, à população, à equipe, às instituições:

Não que elas comecem a correr junto ao nosso lado, mas que elas comecem engatinhando, depois andando, até elas aprenderem a correr... (Equipe 1, Agente 1)

Nós usamos muito o popular. A gente trabalha direto na rua e a gente tem que usar a linguagem deles. (Equipe 1, Agente 2)

Nós somos do governo ... (Equipe 1, Agente 1)

Independente de médico, enfermeira, auxiliar, nós vamos até eles ... (Equipe 1, Agente 1)

Às vezes eles procuram na casa da gente... ou na rua: aonde eles encontram a gente. Eles procuram para saber informações. Eu acredito que eles procuram a gente porque a gente é um representante da unidade ali para eles, naquele momento a gente está representando a unidade. Geralmente eles perguntam: "Ah, o Posto tem vacina? Esta fazendo Papanicolaou?... Estão marcando consulta? Que horas? (Equipe 1, Agente 2)

A gente tem que saber entrar numa casa onde as pessoas têm maior conhecimento, ou menor conhecimento do que a gente. Tem que entrar igual a eles, não pode chegar assim: eu sou agente comunitário, eu estou aqui e você está lá... a gente tem que chegar e falar a linguagem deles para conquistar aquele espaço." (Equipe 1, Agente 3)

Nesse conjunto de depoimentos destaca-se a diferenciação do "nós" (agente identificado com a equipe e a instituição) e eles (população). Entretanto, não há como anular a sua condição de morador da área, apesar de ser uma pessoa em transformação de grupos, de conhecimentos e de práticas:

Porque afinal eu sou uma cadastrada...." (Equipe 1, Agente 2)

Eu venho da comunidade, então eu entendo elas (serem fechadas, desconfiadas)... porque eu também era assim, mas minha cabeça mudou muito a partir do momento que eu estou desenvolvendo este trabalho... porque a gente vive aprendendo todo dia" (Equipe 2, Agente 1)

Em relação aos demais membros da equipe, a identidade do agente é construída pelas características do seu trabalho. Perguntado sobre a diferença do seu trabalho com relação ao do auxiliar de enfermagem, destaca-se, em algumas entrevistas, a referência ao que o agente tem a menos no âmbito da realização de procedimentos técnicos que envolvem materiais/ insumos; no que tange às ações educativas, os agentes parecem sentir-se equivalentes aos auxiliares:

Ah, a diferença é que a gente não pode fazer inalação, a gente não pode medicar, a gente não pode... recolher sangue na área. ... É só essa a nossa diferença, porque tudo 
que eles palestram... as orientações que eles dão, a gente dá a mesma. ... As visitas também são feitas do mesmo jeito, a não ser curativo, que os auxiliares têm que fazer e nós não podemos. (Equipe 1, Agente 1)

\section{A ESPECIFICIDADE DO TRABALHO NÃO PARECE PASSAR, PORTANTO, SÓ PELA CAPACITAÇÃO QUE PODE SER MUITAS VEZES EMPÍRICA, MAS, EM MUITAS SITUAÇÕES, PELA REGULAMENTAÇÃO PROFISSIONAL, COMO NÃO ESTAR AUTORIZADO A FAZER CERTOS PROCEDIMENTOS.}

Ao auxiliar é atribuída uma função mais operativa e menos continente, a disponibilidade de tempo aparecendo como condição importante:

Uma coisa que o povo conta para nós não conta para o auxiliar; o auxiliar vai nas casas rápido, com pressa porque vai fazer um curativo. Nós temos mais tempo para ouvir as pessoas, assim com calma, orientando... Cada um tem a sua função. (Equipe 2, Agente 2)

Nas entrevistas com os agentes que dispõem de um entendimento mais positivo sobre a sua função - destaca-se este um a mais do trabalho do agente, que é a relação com a população:

Nós que somos o olho do projeto QUALIS... nós que vamos nas casa, que vemos tudo, as necessidades... (Equipe 1, Agente 2)

O agente conhece a realidade de toda a sua área, conhece cada pessoa (ou quase todas). O serviço do auxiliar é aplicar injeção, fazer uma vacina, verificação de pressão arterial, um curativo, e vão (nas casas) ver uma pessoa acamada, fazer uma sensibilização. A diferença que eu acho é que o agente conhece tudo assim da área e o auxiliar não. Se você não levar ele até essa família ele não vai saber. (Equipe 1, Agente 4)

A nossa função é a informação, a orientação... Não só a gente informa a população, mas também traz informação da população para dentro do Posto. ... A gente não trabalha só no sentido de informar sobre a doença, mas lá a gente está vendo o que precisa: se a familia precisa de algum tratamento de água, de esgoto... o tratamento do lixo... (Equipe 1, Agente 3)

Eu vou nas casas... eu vejo o meu trabalho como muito importante porque eu posso estar ajudando as pessoa... (por exemplo) sair de uma depressão, sair de uma tristeza... e é gratificante para a gente, não em salário, mas em termos de pessoa... chega em casa e está realizada. (Equipe 2, Agente 2) 
Portanto, o agente de saúde, de um lado, é um observador qualificado da situação de saúde e necessidades das famílias - algumas vezes, para o trabalho da equipe, de outro interfere nessas situações através do que concebe como orientação. Uma terceira característica do trabalho do agente, é o vínculo de vizinhança e a mobilização:

O auxiliar de enfermagem está mais ligado na área de medicamentos. Agora o agente, não, porque ele é mais um mobilizador mesmo. Por maior que seja o vínculo da equipe com as pessoas, o do agente comunitário é sempre maior, porque a gente está ali no dia a dia, sempre indo naquela casa. Porque fora isso, ele é um vizinho, um amigo... não é só a "menina do Posto". (Equipe 2, Agente 1)

\section{A "boa prática" do agente de saúde parece ser a de dedicar-se "de corpo e alma" ao outro, à comunidade:}

Minha família tem ciúmes... eles falam assim para mim: "Ah, Mãe, você pensa mais na comunidade do que em nós mesmos... você não faz mais bolo, não faz mais nada para nós... você só pensa neles. Dá a impressão que a sua família são eles. (Equipe 2, Agente 1)

\subsection{O Agente Comunitário de Saúde pelos demais sujeitos do QUALIS}

\subsubsection{Nível Central - formuladores e gestores}

Conforme pôde ser depreendido das informações sintetizadas no Quadro 4.14, os formuladores de Políticas de Saúde e os gestores do Projeto QUALIS não têm um consenso em relação ao trabalho do agente comunitário de saúde, talvez relacionado com o seu relativo distanciamento da organização do trabalho assistencial.

Nas entrevistas analisadas identifica-se em um pólo, uma concepção do agente que se denomina "dinamizador para mudança social via promoção da saúde"; no outro pólo, a expectativa de que o agente seja um elemento primordial da estratégia de vigilância à saúde, quer na identificação de problemas, quer no acompanhamento e controle de situações de maior vulnerabilidade. Em um ponto intemediário entre esses pólos, identifica-se ainda uma proposta que mescla a vigilância à saúde das pessoas (abordagem do indivíduo e dos moradores de uma mesma casa) e mobilização da comunidade (carente) para acesso a serviços e benfeitorias.

\subsubsection{Nível Local - gerente, demais profissionais da equipe e membros da comunidade}

Apresenta-se, em anexo, um quadro resumido com informações da entrevista com os gerentes locais e membros da equipe (médico, enfermeira e auxiliar de 
enfermagem) das 4 unidades estudadas, (Anexos 4.1, 4.2, 4.3, 4.4) que representam a concepção de que são portadores sobre o QUALIS: objetivos, população alvo, necessidades e problemas de saúde, estratégias de atuação, programas e protocolos, registro e avaliação, atuação dos diversos profissionais, dificuldades, significado do QUALIS para a população e requisitos para trabalhar no QUALIS, além de impressões e planos pessoais. Esse conjunto de pontos conforma um pano de fundo para entender aonde e como se coloca o trabalho do agente comunitário de saúde. 
Quadro 4.14 Apresentação sintética de respostas envolvendo o trabalho do agente comunitário de saúde em entrevista sobre o QUALIS realizada com formulador de políticas públicas e gestores técnicos da área da saúde

\begin{tabular}{|c|c|c|c|}
\hline & Formulador 1 & Gerente técnico 1 & Gerente técnico 2 \\
\hline $\begin{array}{l}\text { 1. Papel do agente de } \\
\text { saúde }\end{array}$ & & & Novidade do projeto \\
\hline $\begin{array}{l}\text { 2. Natureza da ação do } \\
\text { agente de saúde }\end{array}$ & & & \\
\hline $\begin{array}{l}\text { Aplicação cadastro } \\
\text { Educação } \\
\text { Prevenção }\end{array}$ & Primordial (1) & $\begin{array}{l}\text { Menciona } \\
\text { Menciona }\end{array}$ & $\begin{array}{l}\text { A população é } \\
\text { conhecida através do } \\
\text { agente } \\
\text { Menciona }\end{array}$ \\
\hline Vigilância à saúde & Secundário & Menciona & $\begin{array}{l}\text { Acompanha situação de } \\
\text { saúde }\end{array}$ \\
\hline 3. Local da ação & & Fora da unidade & \\
\hline $\begin{array}{l}\text { 4. Formas de atuação } \\
\text { Colhe e registra } \\
\text { informações } \\
\text { Identifica problemas } \\
\text { nas casas e no bairro } \\
\text { Traz os problemas } \\
\text { para a equipe discutir } \\
\text { Leva mensagens da } \\
\text { equipe/ informações } \\
\text { para as famílias } \\
\text { Encaminha pessoas } \\
\text { para a unidade } \\
\text { Execução de } \\
\text { procedimento técnico- } \\
\text { instrumental de } \\
\text { enfermagem } \\
\text { Conversa com as } \\
\text { pessoas sobre problemas } \\
\text { do bairro } \\
\text { Entusiasmar as } \\
\text { pessoas para atuarem }\end{array}$ & & $\begin{array}{l}\text { Menciona } \\
\text { Sobre qual é a melhor } \\
\text { forma de atuar } \\
\text { Menciona } \\
\text { Não faz }\end{array}$ & $\begin{array}{l}\text { Isso é pouco } \\
\text { Menciona } \\
\text { Menciona } \\
\text { Deveria fazer mais do } \\
\text { que isso } \\
\text { Menciona } \\
\text { Menciona }\end{array}$ \\
\hline $\begin{array}{l}\text { Organização do trabalho } \\
\text { Seleção e } \\
\text { treinamento } \\
\text { Educação continuada } \\
\text { Supervisão } \\
\text { Reuniões de equipe } \\
\text { Produtividade } \\
\text { (visitas por dia) }\end{array}$ & & $\begin{array}{l}2 \mathrm{vezes} / \mathrm{semana} \\
10 \mathrm{visitas} / \mathrm{dia}\end{array}$ & \\
\hline Condições para o & & Capacidade física & Morar na comunidade \\
\hline
\end{tabular}




\begin{tabular}{|c|c|c|}
\hline trabalho & & $\begin{array}{l}\text { adscrita } \\
\text { Estar atento, estar ligado } \\
\text { no que vê e ouve } \\
\text { Estar em cima para } \\
\text { controlar }\end{array}$ \\
\hline $\begin{array}{l}\text { Natureza da interação } \\
\text { Elo de comunicação }\end{array}$ & Comunidade-equipe & $\begin{array}{l}\text { Comunidade-equipe e } \\
\text { equipe-comunidade }\end{array}$ \\
\hline $\begin{array}{l}\text { Chamamento para } \\
\text { reuniões }\end{array}$ & Menciona & \\
\hline $\begin{array}{c}\text { Mobilização/ } \\
\text { participação social }\end{array}$ & & $\begin{array}{l}\text { Fazer as pessoas verem } \\
\text { os problemas e perceber } \\
\text { aonde vão ter que } \\
\text { reivindicar (ex lixo) } \\
\text { Como cuidar para ter } \\
\text { seus direitos }\end{array}$ \\
\hline $\begin{array}{l}\text { Fundamento da } \\
\text { interação }\end{array}$ & & Não ser assistencialista \\
\hline
\end{tabular}

Com esse objetivo, tecem-se algumas considerações de aspectos comuns do conteúdo das entrevistas, sem o intuito de diferenciar as opiniões segundo a inserção profissional.

De forma geral, destaca-se, no QUALIS, o acompanhamento da família como um conjunto na unidade e no domicílio, com vistas a alcançar melhor qualidade de saúde e vida. O trabalho da equipe está baseado em uma humanização do atendimento para a qual é importante o vínculo com as pessoas e as famílias. Os profissionais listam uma série de necessidades relacionadas com as condições de vida e informam que grande parte da assistência é realizada para pessoas com hipertensão e diabetes, especialmente em áreas com população mais idosa. Entre as atividades mencionadas destacam o atendimento individual, com menor referência relativa às atividades educativo-assistenciais em grupo e as ações comunitárias. Quase todos identificam problemas com o fornecimento de medicação e acesso a serviços de referência, tanto ambulatoriais como leitos para internação. Identificam que a população está satisfeita com o atendimento do QUALIS, especialmente considerando que, no passado, a maior parte das unidades estavam praticamente desativadas ou mesmo fechadas, mas que há reclamações, especialmente pelo acesso a pronto-atendimento e pela existência de necessidades não abrangidas pelo QUALIS. Os entrevistados relatam que cada membro da equipe tem a sua função: o médico e a enfermeira com carga assistencial importante (na unidade e em visitas a algumas condições específicas); a enfermeira 
ainda acumulando atividades de supervisão da enfermagem e dos agentes; a auxiliar de enfermagem também com atividades na unidade e externas; e o gerente como contato com serviços de referência, com a Coordenação do QUALIS e com a população. Entre as dificuldades para a execução do trabalho destaca-se a referência à sobrecarga ocasionada pela responsabilidade por número de famílias considerado excessivo, à falta de medicamentos e às difículdades com os serviços de retaguarda da unidade básica, além da abordagem de situações sociais, como violência e desemprego, que têm repercussão na saúde das pessoas. Alguns profissionais identificam problemas também no modelo assistencial, de como dar conta, ao mesmo tempo, da assistência a grupos de risco epidemiológico e garantir espaço no trabalho para ações de prevenção e de promoção da saúde; outro desafio é o próprio objeto de atuação, o deslocamento da abordagem do indivíduo para a família e o meio ambiente.

Quanto aos requisitos identificados para trabalhar em uma equipe do QUALIS, destacam a capacidade de atuar em equipe, uma visão mais holística da saúde, a habilidade para o contato interpessoal, além de aspectos relacionados com uma postura ético-política, traduzidos, pelos entrevistados como "ter compromisso", "envolver-se com o trabalho" e "almejar eqüidade social".

Foram ainda analisadas 5 entrevistas realizadas com membros da comunidade (Anexo 4.5), vinculados principalmente a grupos religiosos e movimentos ligados à área da saúde. Chamam a atenção as críticas às dificuldades de acesso ao atendimento imediato e à falta de medicação; em uma das entrevistas encontra-se referência ao excesso de rigor nas orientações realizadas pela equipe de saúde da família (Anexo 4.6).

A partir desse panorama, passa-se a apresentar a opinião dos entrevistados sobre o trabalho e características do agente comunitário de saúde.

O agente de saúde é destacado por muitos dos entrevistados como o “diferencial" do PSF, quando comparado a outros modelos de atenção. Nele se deposita não só uma série de responsabilidades, mas a possibilidade de transformação:

O grande detonador, o modificador, o transformador do modelo do QUALIS é o agente comunitário. (Equipe 1, gerente)

O agente comunitário, que faz a ligação entre a comunidade e a unidade de saúde, isso para mim é o diferencial mais importante dentro desse projeto. (Equipe 2, gerente) 
$O$ agente comunitário é o grande pivô de tudo. Ele é a pedra fundamental do programa, porque ele é que está ali com a população, é ele que tenta resolver alguma coisa, dentro da capacidade dele, é ele que está trazendo para a equipe os problemas. (Equipe 3, enfermeira)

Para mim o que mais me agrada no Projeto é o agente comunitário, porque é aquela pessoa dentro da casa e dentro da unidade que trás todo tipo de informação para você. (Area 1, membro da comunidade 2 )

As funções do agente são definidas pelo seu pólo positivo - o que ele faz; e pelo pólo negativo - o que ele não faz:

A função específica, quase exclusiva dele, é a visita à família. (Equipe 1, gerente)

Ele vai para as casas, ele faz a visita, ele conversa com as pessoas... ele dá orientação, detecta problemas... (Equipe 2, enfermeira)

Ele é o articulador de todo esse processo, que traz a demanda, que tem um vínculo muito grande não só com a clientela... na verdade a jornada dele acaba não sendo de 40 horas, porque Sábado, Domingo, eles são abordados, são reconhecidos pela comunidade enquanto elementos da saúde. (Equipe 4, gerente)

Os agentes às 7 horas da manhã vêm para o Posto, o que está escalado fica no acolhimento das 7 às 9 horas. Depois do acolhimento ele sai, programa a pastinha dele, sai para fazer visita domiciliar. Tendo algum problema ele vem, conversa com o médico, com a enfermeira e a gente já agenda consulta, ou para um dia determinado ou, se tem alguma urgência, a gente sai, mesmo em horários indeterminados. (Equipe 3 , enfermeira)

$O$ agente comunitário visita todas as famílias e trabalha a prevenção... o agente comunitário é o que trabalha mais profundo mesmo a prevenção das doenças, com as orientações que ele passa para a comunidade. (Area 1, membro da comunidade 2)

$O$ agente não dá medicação, é observador, faz orientações na área; o auxiliar de enfermagem é operador. (Equipe 1, médico)

O agente também é a extensão do olhar da equipe para além dos muros da unidade: é ele que identifica as condições de vida das famílias e a necessidade de um cuidado de outros profissionais:

Ele é o mais importante da equipe. Se não fosse ele, não poderia estar trazendo os problemas para a unidade... Ele olha do recém-nascido ao vovô, ele olha a família como um todo. Ele capta todos os problemas, se tem hipertenso, diabético, gestante... se tem esgoto a céu aberto, se a caixa d'água é fechada, se bebe água filtrada... a condição de moradia, se está empregado ou desempregado. Toda essa parte é ele que vê; a gente vai lá depois que ele vê tudo isso e relata na reunião de equipe... Ele vivencia bem mais do que a gente. (Equipe 1, auxiliar de enfermagem) 
O agente faz visita sequencialmente, ou seja, casa por casa. Vai perguntar se está tudo bem, a questão da prevenção mesmo... como é que está a caixa d'água, como é que está a casa, se tem alguém que teve uma doença e não veio à unidade... ela dá informação sobre alimentação... ela faz aquele primeiro olhar que é do agente comunitário... Através dos olhos da agente, da avaliação da agente, ela traz para a equipe se ela tiver algum problema que ela não pôde resolver na área, e aí é onde a gente intervém. (Equipe 1, enfermeira)

Todos fazem visita domiciliar, mas é sempre o agente, vamos dizer, que detona a necessidade de visitas ou não. (Equipe 2, gerente)

Se há consenso de que a rua e as casas são os espaços próprios de trabalho do agente, para as atividades desenvolvidas na unidade, como participar de grupos educativos e do acolhimento, não há consenso. Encontram-se diferentes formas de organização da prestação de assistência entre as unidades, além de divergência entre os profissionais, evidenciando, ainda, uma busca de adequação da organização da assistência:

O agente comunitário já foi bem capacitado para o acolhimento... ele vê o que precisa passar na hora... ele já tem condição para avaliar se aquele caso pode passar para o agendamento ou para a enfemeira. (Equipe 3, enfermeira)

Os agentes são facilitadores do grupo educativo. (Equipe 2, médico)

O agente é também o responsável pelo levantamento de dados iniciais sobre a população e pela apresentação do PSF no contato com cada família, porta-voz dos objetivos e sua organização:

Através do cadastro do agente comunitário, entrevistando cada pessoa, é que levantou o número de problemas, e com esse número, como se iria trabalhar com os cinco principais: a hipertensão, a diabete, a gestante, criança menor de 1 ano e a criança de 1 a 5 anos. (Area 1, membro da comunidade 2)

Toda a questão do QUALIS, o que é, como é, é trabalho do agente. Ele é que vai lá e diz: "Olha, o nosso trabalho é assim, ou não é tal". (Equipe 2, enfermeira)

Outra faceta do trabalho do agente é dar suporte aos profissionais da equipe nas suas incursões externas. Uma primeira tarefa é a de conduzi-los até o local necessário, fazer a apresentação, prestar esclarecimentos, mediar a relação:

Ele acompanha todas as visitas do médico, da enfermeira e da auxiliar. (Vila Gulhermina, gerente) 
Sem eles não teríamos acesso a informações. Eles é que abrem a porta para nós entrarmos. Eles ganham, eles cativam as famílias para nós entrarmos. Eles são a porta de entrada do Projeto. (Equipe 4, auxiliar de enfermagem)

$\mathrm{O}$ agente tem ainda como tarefa levar mensagens e insumos (receitas, encaminhamentos, relatórios, medicação). Observamos essa função na comunicação de data de consulta, convite para vacinação, grupo educativo, reunião do Conselho de Saúde. Esse trabalho criticado pelos profissionais quando o seu objetivo é mais "burocrático", como desmarcar e marcar consulta, mas considerada pertinente se for o caso de levar encaminhamento, medicação ou reforço a determinada conduta ao paciente:

Se vai ter uma reunião que não foi planejada com antecedência, aí tem que mandar o agente desmarcar tudo, uma trabalheira... (Equipe 2, médico)

No entanto, na presença dos outros profissionais da equipe, o trabalho do agente de saúde pode aparecer como que restrito ao de "acompanhante":

(A equipe) é composta das agentes, que faz as visitas domiciliares, atendentes que estão ali para acompanhar as auxiliares de enfermagem. (Area 2, membro da comunidade 3 )

Para a população, o agente tem um papel às vezes mais ampliado, de ajuda, de socorro, especialmente importante em condições de vida precárias e com dificuldades de apoio por outros serviços públicos. Presente em situações difíceis, estreita-se o laço entre algumas famílias e os agentes.

A Dona... que é a agente da minha rua, a minha agente... eu falo minha agente, sabe? Então, tudo que é coisinha... é o anjo da guarda da gente que ... qualquer coisinha eles correm... (Area 1, membro da comunidade 1)

As pessoas vêem nele (agente de saúde) um tudo... se transforma em um membro da familia, é um amigo que no fim do ano a gente dá presente... (Area 1, membro da comunidade 2)

\section{PARA A EQUIPE DE SAÚDE, O AGENTE COMUNITÁRIO TAMBÉM É O DESENCADEADOR DE ATIVIDADES EXTRAORDINÁRIAS DA EQUIPE, COMO A VISITA AO RECÉM-NASCIDO:}

As visitas (mensais) são programadas. As visitas de emergência sempre acontecem com os recém-nascidos. Vem a notícia que tem um recém-nascido, há uma visita de emergência, uma visita que não está no dia programado. Com 24 a 48 horas depois que o bebê chega, a gente tem que visitar. (Equipe 3, gerente) 
$\mathrm{Na}$ análise das entrevistas, detectam-se cinco funções do agente comunitário de saúde que, se considera, merecem um destaque. São elas a: de conhecedor da população; a de facilitador do acesso a serviço de saúde; a de elo entre a equipe, a família e a comunidade; a de acionador de atividades; e, ainda, a de controlador dos indivíduos, das famílias e da equipe.

\section{- agente conhecedor da população}

O conhecimento que o agente de saúde tem das famílias e das pessoas é incorporado por profissionais da equipe como instrumento tanto de gerenciamento, como para nortear o tipo de atendimento necessário, na unidade ou em casa:

Na reunião da próxima segunda-feira, eu vou combinar com os agentes para eu estar indo todo dia em uma casa, não em qualquer casa...; o agente, ele sabe qual é aquela família mais resistente e que reclama mais do posto, e este reclamar do usuário tem muito a ver com gerenciamento... (Equipe 1, gerente)

Ela ajuda também no acolhimento (na unidade)... ela já conhece o usuário melhor do que a gente... às vezes é um usuário que vem para a unidade por ansiedade e ela já sabe que o problema dele é esse, e ela já conversa com a gente, já especifica... (Equipe 1 , enfermeira)

O agente conhece não só as pessoas, mas também as casas e o modo de vida dos seus habitantes e atua como um prolongador dos olhos e da apreensão da equipe:

O agente no momento que está fazendo o cadastro já olha as instalações da casa... discretamente ele já está examinando as instalações. Ele já tem o treinamento para que ele olhe se a pessoa é orientada para higiene, alimentação... tudo isso ele já capta e já fica sabendo se existe doença crônica naquela família e quais os tipos de doença crônica... se tem uma acamado...Ele vê e ele já anota e passa para a gente... (Equipe 2 , gerente)

É o agente comunitário que encontra as pessoas, que sabe que naquela casa ali tem muita poeira, tem muito pó e é ele que requisita uma visita nossa. Nós vamos lá para identificar o problema de outro prisma, porque só o tratamento não resolve, porque às vezes o problema está na casa. (Equipe 3, enfermeira)

\section{- agente facilitador do acesso a serviço de saúde}

$\mathrm{O}$ agente tem a função de prestar informações à população sobre as atividades desenvolvidas na unidade e as formas de acesso. É o agente também que leva o "caso" da família para discussão na reunião de equipe e que, muitas vezes, é o desencadeador da vinda de um outro profissional à casa. Na relação do agente com a família e com a equipe estão em jogo não só os procedimentos necessários aos cuidados da saúde, mas relações de barganha e poder: 
Tal agente quer que a Doutora vá em tal lugar porque precisa, é necessário... (mas a equipe discorda) Ai de repente muda (a história): "Ah, mas eu prometi, Doutora." Aí, quando fala: "Eu prometi para ele"; aí, pronto, acabou!. É o nome dela que está em jogo. Então vamos priorizar, porque nós temos que dar prioridade... (Equipe 2, médico)

Uma parte expressiva do trabalho dos agentes é o "levar mensagens" como o agendamento para tratamento de saúde bucal, que representa um cuidado recém incorporado de forma oficial no PSF e que, nas unidades do QUALIS, suscitam uma grande mobilização da população em busca de vagas, e dos agentes em torno da distribuição de senhas:

Essa coisa da gente chegar e escrever o nome da pessoa em um bilhetinho, mandar o agente na casa e o agente bate na porta da sua casa e fala: "Ó você tem dentista marcado tal dia, eu acho que é uma comodidade para a pessoa que vem aqui... (Equipe 3, dentista)

Nesse relato pode-se notar o papel de mensageiro do agente de saúde, às vezes tomado como "mandado" pelo profissional médico ou dentista:

Eu acho que o agente é um ponte entre a população e o Posto de Saúde, como se fosse um pombo-correio. Sai aqui do posto e leva uma mensagem para o paciente e tem paciente acamado que não pode sair, vem chama e leva o médico. (Equipe 3, dentista)

\section{O AGENTE É TAMBÉM RESPONSÁVEL PELA EMERGÊNCIA DE NECESSIDADES DE SAÚDE, CONFORMANDO PARTE IMPORTANTE DA DEMANDA DA UNIDADE BÁSICA:}

No começo foi a demanda espontânea, porque os agentes comunitários entraram depois da gente. E ai os agentes, com o cadastramento foram trazendo os casos. Eles orientavam: "Olha, vá lá no posto, que tem médico, que está funcionando." Até que a nossa demanda ficou grande... Então a captação e a manutenção dos pacientes é muito mesmo pelo agente comunitário. (Equipe 4, médico)

\section{- agente elo equipe-famílias e comunidade}

A figura do agente como "elo" é destacada de forma extensiva em muitas das entrevistas. Responsável pelo contato de dupla mão equipe-população adscrita, ele também é visto como elemento importante para garantir o vínculo e a humanização almejados pelo Programa, além de incentivador da participação e da organização da comunidade, para o controle social do serviço de saúde: 
O agente, eu acho que é o que dá grande diferença a este projeto. Porque ele é o elo de ligação entre a equipe e a comunidade. É ele que faz esse gancho, essa interação, essa humanização do atendimento. Eu acho que é um elo fundamental. (Equipe 4, gerente)

Os agentes é que ocupam o principal lugar no Projeto QUALIS, por conta de que eles é que estão em contato direto com a família. Eles é que estão visitando, entrando nos lares... adquirindo confiança... conquistando essa confiança com as famílias... e vendo a necessidade de consultas, de tratamentos, detalhes, da saúde mental. É o próprio agente comunitário que detecta isso. E ele traz para a equipe. (Equipe 3, gerente)

O agente comunitário é a nossa referência para contato com aquela família, ele faz o entrosamento... porque como ele está lá sempre com a familia ele cria um vínculo muito maior do que o meu ou da Doutora... eles acabam se abrindo para os agentes em coisas que a gente nunca poderia imaginar... esse vínculo que ele faz com o agente é muito importante para o nosso trabalho. (Equipe 2, enfermeira)

O que mais me agrada (no PSF) é o vínculo com a família, esse olhar para o indivíduo enquanto família, comunidade, meio onde ele vive, esse olhar integral... Eu respeito $e$ admiro muito o agente comunitário, eu acho que sem ele a gente não conseguiria avançar como agente avançou nesse modelo. (Equipe 1, gerente)

$O$ agente também é o maior elo... ele conhece a comunidade, ele conhece as instituições, ele conhece onde a gente pode se inserir melhor, ele é que nos indica todos esses pontos... ele faz os contatos e aí a gente vai... é ele que faz a nossa apresentação... (Equipe 2, enfermeira)

O agente de saúde é um elo importante (no acolhimento)... porque ele conhece a casa e conhece cada um que vai resolver cada coisa. E ele conhece melhor do que qualquer um. (Equipe 2, médico)

O agente comunitário é o mobilizador: se tem algum evento é ele que vai e põe o cartaz na área, é ele que convida. Nos grupos educativos ele participa como um mobilizador, como um apoio da equipe para a realização dos grupos. (Equipe 1, gerente)

Os agentes fazem a convocação para os grupos educativos, eles entregam os convites, eles participam, ai tem o auxiliar, o enfermeiro... (Equipe 2, auxiliar de enfermagem)

Quem aciona as famílias para a reunião (do Conselho de Saúde) são os agentes comunitários do posto. (Equipe 1, auxiliar de enfermagem)

A reunião do Conselho de Saúde é aberta para toda a comunidade, tem o presidente do Conselho, participam os agentes também, sempre na frente de tudo. É organizado entre eles mesmos. (Equipe 2, gerente)

(As pessoas do bairro participam de coisas que acontecem no QUALIS)...elas sabem através de cartazes ou antes, dos agentes, eles que chamam para os eventos que a gente faz. (Equipe 2, enfermeira) 
No entanto, a posição de elo entre a unidade de saúde e a comunidade coloca um desafio para a identidade do agente, tensionando-a de um e de outro lado. $\mathrm{Na}$ opinião de alguns entrevistados, o agente pende para a instituição:

(Para relacionamento do QUALIS com a população) nós temos o Conselho de Saúde, fora o trabalho dos agentes que é uma relação com a comunidade, eles trazem os problemas para a reunião. Eu faço reunião com os agentes em separado... mas o Conselho de Saúde aqui é muito fraco, ele tem pouca experiência...E os agentes não têm ainda claro esse papel deles de intermediários com a população. Os agentes daqui ainda são muito assistencialistas com a população. Às vezes eles defendem a unidade e não a população... A gente está tentando mostrar o papel deles como educadores, como entrar em contato com a população... (Equipe 2, gerente)

Por outro lado, não há uma reflexão sobre esse "elo", na perspectiva das diretrizes do programa.

- agente controlador (do indivíduo, da população e do trabalho da equipe)

A população cadastrada e a visita domiciliar do agente se somam como estratégias de controle da continuidade do tratamento:

A gente trabalha com população fechada, então é muito mais fácil o controle... Eu tenho um controle pelo agente que vem e fala: "Fulano precisa de medicamento, ele está sem medicação." Fica mais fácil. (Equipe 1, médico)

\section{NA ESTRATÉGIA ADOTADA DE CONTROLE DE GRUPOS DE} RISCO, O AGENTE DE SAÚDE É INSTRUMENTO PRIVILEGIADO CONFERINDO, NA CASA DO INDIVÍDUO, O SEGUIMENTO DOS CUIDAdOS, A DIETA, A ATIVIDADE FÍSICA, O USO DE MEDICAÇÃO E O COMPARECIMENTO AOS ATENDIMENTOS. ESTA VIGILÂNCIA, DE TIPO DISCIPLINAR, POSSIBILITA UMA REORGANIZAÇÃO DO TRABALHO ASSISTENCIAL:

$O$ agente está em cima, eles fazem as visitas mensais, ou até quinzenais, quando é o caso. Eles perguntam: "Está tomando o remédio?”. Contam (para a equipe) dos casos mais rebeldes... Então essa é a nossa vantagem: estar realmente em cima do paciente, entrando na casa dele. (Equipe 4, médico)

Então eu vou espaçando (o retorno do hipertenso controlado) - dali 3 meses, depois 6 meses - isso não quer dizer que eu perdi o controle, porque eu tenho o agente comunitário que faz o seu trabalho de visitação, para saber se o paciente está bem, se está tomando os medicamentos. (Equipe 4, gerente)

O agente também controla a adequação e a eficácia o trabalho da equipe:

$O$ agente comunitário na área avalia a intervenção da equipe sobre aquela família... ele vê realmente, por exemplo, se a mãe que você visitou está dando de mamar para a 
criança ou se a mãe disse que ia dar a mama e não está dando. (Equipe 1, enfermeira)

O agente é o que informa a gente. Tudo o que está acontecendo... o que está dando resultado, o que não está dando resultado, quem está seguindo, quem não está seguindo, quem precisa fazer isso, quem não precisa... o agente é comunicação total. É comunicação. (Equipe 4, enfermeira)

$O$ agente foi colocado estrategicamente para incomodar o médico, mas eles são os meus tentáculos. Ele que vê, que sente, que sabe ... ele é que me informa o que está acontecendo na comunidade, ele chama a minha atenção (para um problema). Na experiência em Niterói, como médico de família, eu não tinha o agente; eu fazia tudo: pegava a bola, defendia, fazia gol. Era muita coisa! (Equipe 1, médico)

Para responder a essas atribuições, os membros da equipe entrevistados listaram uma série de características necessárias ao Agente de Saúde. Além da pré condição de morar na área em que trabalha, foi dada ênfase ao vínculo com a comunidade:

Tem que mostrar interesse e morar na área. (Equipe 1, médico)

Um dos critérios de seleção é que sejam pessoas que têm história de vida de participante da população, como a gente chama "lideranças comunitárias"... (Equipe 1 , gerente)

O agente é um ser da comunidade, é um morador que está querendo ajudar a sua comunidade. Quando ele começa a fazer o seu trabalho, ele se sente uma pessoa como que responsável também pela saúde dessa comunidade... Ele é um líder porque ele vai dialogar com as pessoas e tentar buscar as pessoas para que elas melhorem a sua saúde... ele é um facilitador porque a linguagem dele é diferente da nossa e ele assinala o básico... ele faz como que uma fotografia da pessoa que eu não conheço. Ele não é um leva-e-traz... eles opinam nas nossas atividades. (Equipe 2, médico)

$O$ agente de saúde não é um mero visitador domiciliar. É alguém da comunidade escolhido porque já tem liderança, então ele, até pela cidadania, ele tem as características próprias dele... já tem isso inserido como perfil... é uma pessoa que tem essa questão da liderança, da mobilização, do interesse pelo outro... está disposto para atender o outro... É uma pessoa que tem uma visão dos problemas, divide os problemas junto com a comunidade... O QUALIS vê o agente comunitário como uma pessoa que vai intervir positivamente junto à comunidade... que não vai só visitar e fazer um levantamento de dados... (mas) vai intervir continuamente. (Equipe 1, enfermeira)

$O$ agente comunitário de saúde é assim da população... é a comunidade dentro do serviço de saúde. Ele é a comunidade que está trabalhando dentro do serviço de saúde, então ele expressa a vontade da comunidade e tem a confiança da comunidade.... (Area 1, membro da comunidade 2) 
O trabalho externo à unidade, o chegar nas casas e contatar as famílias, é reconhecido como uma atividade que exige desempenho físico e habilidade técnica, que é interpretada como de cunho psicológico ou comunicativo:

Não é só a escrita (necessária para o trabalho do agente), mas também a parte psicológica. Para o atendimento boca a boca que as meninas vão fazer, para contato com as familias elas têm que ter um preparo. Então não pode ser qualquer um, porque todos têm a capacidade, mas tem aqueles mais controlados, que sabem distinguir uma coisa da outra. (Area 2, membro da comunidade 3)

O serviço deles é minucioso. Eles estão atentos a tudo... Ele tem uma comunicação com a população, um vínculo com a população, que eu fico de queixo caído. (Equipe 4, auxiliar de enfermagem)

Uma agente comunitária, ela tem que agüentar tudo, não é? Já pensou se a agente chega em uma casa de família e chega um estúpido lá falando: "Ah, isso não me interessa."... Acho que a escolha (seleção) foi para ver a capacidade de cada um. (Área 1, membro da comunidade 1)

O trabalho do agente, além dos aspectos técnicos, exige atributos morais definidos pelos entrevistados como "humanidade", gostar de conversar, ser paciente, mas também perseverança e idealismo:

Um dos fatores (que contribuíram para que o QUALIS fosse respeitado em São Paulo) é o agente comunitário, porque ele entrou com muitos sonhos, com muita garra... (Area 1, membro da comunidade 2)

O agente comunitário ainda é participante importante das atividades festivas da equipe, da unidade, da comunidade pois "as comemorações são com elas". (Equipe 4, enfermeira)

Destacam-se, aqui, três outros aspectos considerados relevantes no trabalho dos agentes e que têm um contraponto nos demais membros da equipe e da comunidade. São as atividades comunitárias, a questão da aderência ao seguimento de saúde e ao tratamento proposto e as reuniões de equipe. A primeira, por sua relevância em um projeto que enfatiza como um dos seus objetivos a promoção do auto-cuidado, da cidadania; a segunda pela hipertrofia das atividades de vigilância à saúde especialmente de indivíduos com risco cardiovascular; e a terceira como instrumento privilegiado de trabalho da equipe e de elaboração da tecnologia necessária ao modelo assistencial em construção.

\section{As Atividades Comunitárias}




\section{SE OS CONSELHOS DE SAÚDE LOCAIS ABREM UM ESPAÇO}

PRIVILEGIADO DE CONTATO DA POPULAÇÃO COM A UNIDADE, ELE, MUITAS VEZES, ACONTECE SOB EMPENHO DA UNIDADE, SENDO A PARTICIPAÇÃO DA POPULAÇÃO VARIÁVEL. MESMO NAS EQUIPES, OS FUNCIONÁRIOS QUE NÃO SÃO "MEMBROS NATOS”, COMO EM MUITOS LOCAIS ALGUNS DOS ENFERMEIROS E AGENTES DE SAÚDE, TÊM POUCA INFORMAÇÃO SOBRE SUAS ATIVIDADES:

$\dot{E}$ as enfermeiras que chamam para a reunião... Se eu não venho, eles vêm aqui no meu portão... Só mesmo se eu não puder mesmo vir, eu não venho... (Área 1, membro da comunidade 1)

Do Conselho de Saúde fazem parte os agentes comunitários e tem pessoas da comunidade ... e pessoas que, mesmo não fazendo parte do Conselho, vêm nas reuniões... participa com a gente, questiona... (Equipe 1, enfermeira)

Existem reuniões que são feitas com o pessoal do bairro e o QUALIS, mas elas não são muito freqüentadas. É uma pena, porque a turma faz o convite, estende o convite... às vezes que não participa depois sai falando algumas coisinhas que não deve. (Area 2 , membro da comunidade 3)

Há diferentes interpretações e práticas de participação popular. De um lado, a equipe aciona a população para os problemas do seu interesse, de outro, a população é vista como "ajudando" o movimento. De nenhum dos dois ângulos, instala-se uma parceria:

(No episódio da invasão do posto)... a gente fez uma convocação rápida. Eles se mobilizaram e junto com a gente ajudaram a resolver o problema... então eles participam bem. (Equipe 1, enfermeira)

O planejamento mais geral é feito anualmente... A gente faz o planejamento e na execução a comunidade participa, a gente põe a comunidade como participante ativa do planejamento. (Equipe 1, enfermeira)

A comunidade está sempre disposta a ajudar. (Equipe 1, médico)

Se a gente chama para alguma reunião, ou alguma coisa assim, o pessoal vem (Equipe 4, enfermeira) 
Encontra-se o relato de uma série de atividades desenvolvida pela equipe que se identifica como de caráter comunitário quando se distanciam de um objetivo mais imediatamente assistencial e educativo e propiciam o desenvolvimento de relações entre os participantes:

Tem os grupos da terceira idade, que são oficinas culturais, toda Terça-feira na Unidade. Esse grupo já é bastante independente, eles quase se auto-coordenam. Na verdade dois agentes ficam meio de apoio, mas eles já caminham sozinhos. (Equipe 1, gerente)

A gente está em um processo de tentar motivar a população a fazer a multi-mistura, tem que fazer com que a população mesma assuma até mesmo vir aqui fazer a multimistura dela ou na área chamar uma série de mulheres numa casa e ensinar. A gente está nesse processo que eles multipliquem, senão fica sempre a gente só ensinando... um dia a gente sai daqui e acaba tudo! Não pode, não é? (Equipe 1, gerente)

Tem a farmácia caseira, de você usar o que tem em casa, de uma vizinha ensinar a outra: "Olha, fulana, eu tenho aqui no meu quintal uma planta tal, você não quer dar para o seu filho?... é assim que faz" A gente está na tentativa de resgatar entre os jovens essa herança que se perdeu um pouco, com esses remédios que você toma, os Doril da vida, você esquece de ter um pouco de paciência, de tomar um chazinho que demora mas faz efeito. (Equipe 1, gerente)

Uma parte do trabalho da equipe é o que é denominado de "mobilização", entendida como apoio de um movimento social em direção a determinado objetivo:

A gente tem que ensinar a eles a encontrar a resposta... que nem o pessoal lá de cima, onde o lixeiro não passa... e o daqui, o esgoto a céu aberto... a gente explica isso, ensina como reivindicar os seus direitos, no caso de pavimentação, saneamento básico, lixo... Aqueles suportes para colocar o lixo, ir na prefeitura reivindicar os direitos deles... tem terrenos que são tudo assim, sem cercado, abandonado. Ali vira uma criação de ratos. Tem que pedir na prefeitura para que obrigue o dono a murar aquele terreno, a carpir... (Equipe 1, auxiliar de enfermagem)

As necessidades de infra-estrutura são, muitas vezes, básicas e quando uma é alcançada, outra aparece, demonstrando que a mobilização é condição para que o Estado preste os serviços a que as pessoas têm direito:

Aqui tinha áreas, há 3 anos atrás, que ainda não tinha água, as pessoas usavam ligação clandestina de luz. Então, junto aqui com a unidade de saúde, conseguiu colocar energia e água nesses locais. A luta agora é na questão de colocar esgoto, rede de esgoto em todo o bairro. (Area 1, membro da comunidade 2)

As unidades de saúde da família promovem e fornecem os recursos para muitas atividades de lazer que têm como objetivo tanto angariar fundos como propiciar o 
encontro das pessoas em torno de eventos marcantes para a vida da comunidade. Neste sentido, devido à ausência de muitos outros serviços e espaços físicos, a unidade de saúde é palco de eventos sociais:

A gente sempre promove bingo, faz festa do dia das mães, festa da terceira idade. A Cristina, nossa auxiliar de enfermagem, está fazendo um canteiro no pátio com plantas medicinais... eles traz as mudas de planta, eles mesmos vêm, fazem os canteiros, carpem. A comunidade, eles participam bastante. (Equipe 1, auxiliar de enfermagem)

Fazer reunião e passar abaixo-assinado são atividades comunitárias de cunho reivindicativo. As formas de participação também são variadas e, considerando às vezes a dificuldade de mobilização, tende-se a valorizar qualquer manifestação, como entrar no abaixo-assinado:

Tinha o posto desativado... foi onde eles se mobilizaram para que (o QUALIS) se instalasse aqui. Infelizmente, muitas das pessoas que trabalharam nessa campanha acabaram não sendo cadastrada, porque a área é delimitada. Por isso a gente passa essa orientação para aqueles não cadastrados que nos procuram, a gente pede para eles fazerem o mesmo em outros lugares, para que sejam abertas novas unidades. (Equipe 2, auxiliar de enfermagem)

Eu falei: "Olha, sabe o que você tem que fazer? Um abaixo-assinado, um abaixoassinado com bastante assinaturas. Pergunta em um posto, um lugar onde tenha uma pessoa que entenda, leva as assinaturas, faz que nem nós fizemos no começo. Ai vocês vão ter um QUALIS só para vocês, um posto só para vocês" (Area 2, membro da comunidade 4)

Eu acho que de uma maneira geral (teve participação)... a partir do momento que a pessoa assina a folha já está ajudando, não é? E o pessoal ajudou bem. Num instantinho nós fizemos as assinaturas que precisava. (Area 2, membro da comunidade 4)

\section{Aderência}

Todos os membros da equipe dão importância à aderência e criticam a atitude de muitos usuários, de faltar ao atendimento agendado ou de não cumprir a prescrição:

Se o paciente se tornar um faltoso ele perde o direito ao agendamento, ai ele volta de novo para a fila ou espera para ser encaixado quando houver vaga. (Equipe 1, médico)

Eu tenho um esquema de trabalho assim, eu vejo na minha agenda todo dia quem faltou. O agente comunitário vai atrás. Por que o Sr faltou? A Dra pediu para vir 
saber o que aconteceu. Então ele já começa a ficar envergonhado... (Equipe 4, médico)

Existe muita falta de compromisso do usuário com o seu cartão de agendamento... olha que coisa simples: o compromisso de não faltar aos atendimentos. Eu acho que ainda existe muita falta de compromisso com a sua saúde... isso é uma construção que a gente está investindo. (Equipe 1, gerente)

Identifica-se um empenho especial da equipe de resgatar o usuário, com especial participação do agente, de colocá-lo na linha estabelecida pela equipe. Não há reflexão sobre os motivos da não aderência, de como desenvolver outras estratégias ou de como dialogar com o usuário com suas necessidades e concepções de saúde e de tratamento diferentes das da equipe:

As agentes conhecem bem que é fulano que você precisa ir lá porque ele não vem mais no posto. A gente conseguiu resgatar uma gestante no início do ano: fui na casa dela, expliquei todo o problema que houve com ela... isso é um ganho! (Equipe 1, gerente)

Tem alguns que não seguem a nossa orientação, mas eu insisto, porque é para o bem deles, com certeza a gente vai estar sempre insistindo de uma forma ou de outra.. a gente muda a tática... às vezes tem que sentar, bater um papo... aí o paciente se entrega... (Equipe 2, auxiliar de enfermagem)

Para mudar os costumes lá daquelas pessoas é muito dificil. Porque é um ser humano. Eu mesma, eu tenho as orientações todas e quem diz que eu faço o que o médico me ensinou, o que é bom? Não pode, isso é aos poucos. (Equipe 1, auxiliar de enfermagem)

\section{As Reuniões de Trabalho da Equipe}

As reuniões de cada equipe são freqüentes, variando entre diárias e duas vezes por semana, tendo como objetivo destacado a resolubilidade — não deixar acumular informação e problemas, garantindo uma intervenção eficaz:

Pela manhã temos uma reunião diária e obrigatória, para falar sobre o que aconteceu ontem, para atualizar o dia-a-dia, para não acumular informações. (Equipe 1 , médico)

O foco da discussão na reunião de equipe é a vigilância à saúde, trabalho especialmente do agente; nas reuniões com o gerente da unidade, aspectos mais relacionados com o modelo de atenção do PSF e com as atividades comunitárias:

As equipes se reúnem periodicamente, e fazem estudos sobre as coisas que são trazidas pelos agentes que vão para as visitas... situações ocorridas dentro do trabalho deles... Toda semana faço reunião com os agentes, reunião de uma hora. Reuniões curtas, discutimos coisas do andamento do trabalho deles, do Conselho de Saúde que eles participam. (Equipe 2, gerente) 
As reuniões são espaços de troca de experiências, opiniões e visões sobre os problemas enfrentados pela equipe, envolvendo também as funções dos profissionais, as formas de integração do trabalho, o desenvolvimento de ações que transcendem o âmbito restrito da vigilância à saúde e assistência à doença. Portanto, espaço de reconstrução da prática. Os encontros permitem, algumas vezes a elaboração de um projeto comum de trabalho da equipe:

Em uma unidade comum, o médico tem que ter razão; a enfermeira sempre tem razão. Aqui a gente tem oportunidade de optar. A gente tem uma reunião geral uma vez por mês e a gente tem oportunidade de falar... a gente tem a nossa reunião de enfermagem, e os agentes têm a reunião dos agentes... a gente entra em consenso $e$ consegue ver onde está o nó da coisa. Às vezes tem uma coisa importante que tem um nó... e você não consegue saber onde está. Aí na reunião você consegue tirar esses nós que atrapalham o andamento do trabalho. (Equipe 1, auxiliar de enfermagem)

\section{DISCUSSÃO}

Pretende-se, neste Capítulo, mais do que fazer uma discussão dos resultados já apresentados e comentados anteriormente, proceder a uma síntese, destacando os pontos considerados mais relevantes para a caracterização do perfil ocupacional/social desse agente de realização de determinadas propostas de assistência à saúde - o agente comunitário de saúde, nas suas variadas denominações e funções, como uma expressão de realização das principais justificativas dessas propostas e de políticas específicas.

\subsection{A IDENTIDADE DO AGENTE COMUNITÁRIO DE SAÚDE DO QUALIS}

Como pôde ser constatado na observação do trabalho dos agentes de saúde do QUALIS, a sua atuação está conformada por uma série de elementos. Opta-se aqui por destacar os seguintes: a relação das suas funções com as dos demais membros da equipe; os saberes que orientam o seu desempenho; as formas de supervisão do seu trabalho; e a regulação do seu exercício, elementos de grande importância na definição do seu perfil ocupacional/social e da sua identidade.

Segundo a opinião dos profissionais entrevistados, entre as funções do agente de saúde destacam-se: a de conhecedor da população, organizador do acesso a serviço de saúde, vigilante de riscos e de controlador da aderência aos cuidados de saúde propostos pelo médico e pelo enfermeiro. O agente faz também o contato da equipe de 
saúde com a população, o agente-“elo", tanto nas visitas quanto nos espaços previstos de participação, como o Conselho de Saúde, e, ainda, na mobilização por direitos sociais, como na questão do saneamento e lixo e no acesso a equipamentos sociais, como creche e áreas de lazer. Para os entrevistados, as ações de educação em saúde foram, relativamente, menos lembradas como área de atuação do agente.

No entanto, como pôde ser observado, o conteúdo principal das visitas realizadas durante a observação, girou em torno da situação de controle de saúde (vacinação, prevenção de câncer ginecológico) e de cuidado médico (consultas, exames, medicação, hábitos como dieta e atividade física); o tempo maior de trabalho dentro da unidade, foi ocupado em atividade de acolhimento, de registro de dados, em participação em reuniões.

Às atividades assistenciais, somam-se relatos de ações articuladas a outros serviços públicos e ações comunitárias de solidariedade e de mobilização/transformações sociais.

Portanto, o Programa de Saúde da Família/ QUALIS, que representa uma nova forma de organizar a atenção básica encontra-se, ainda, cativo tanto do predomínio da assistência individual baseada no saber clínico (MENDES -GONÇALVES 1986), como da expectativa do atendimento à demanda espontânea de forma imediata e por profissional universitário, médico ou enfermeiro (DALMASO 1996). A oferta organizada de ações de saúde (PAIM 1995), instrumentalizada no PSF pela priorização de grupos de risco e pela visita mensal do agente às famílias, é o outro pólo da prestação de assistência em tensão com o modelo hegemônico.

Para o seu desempenho, o agente lança mão tanto do saber emprestado dos demais membros da equipe, médico e enfermeiro, como do senso comum. De um lado, são capacitados para o levantamento de informações, as orientações para a prevenção de doença e a conferência dos cuidados e tratamentos, a partir dos conhecimentos da área da saúde. Quando o saber emprestado é insuficiente, os agentes levam os próprios profissionais à casa ou o "caso" à unidade.

No entanto, o saber científico que orienta a medicina e as áreas correlatas, ao ser aplicado a situações concretas desdobra-se em saber operante, uma vez que deve dar conta de outras necessidades não recobertas pela ciência, como os valores, as condições de vida, as relações afetivas (MENDES GONÇALVES 1994). No trabalho do agente está incluída uma série de situações para a qual a área da saúde ainda não 
desenvolveu um saber sistematizado e instrumentos adequados de trabalho e gerência, desde a abordagem da família, o contato com situações de vida precária que determinam as condições de saúde, até o posicionamento frente à desigualdade social e a busca da cidadania. Para lidar com essas condições, se as regras não estão definidas, o agente lança mão do senso comum, valendo-se de suas experiências e crenças (WILSON 1989). No entanto, o agente não é o parente, mas alguém imbuído de funções e autoridade.

Para dar conta da elaboração do saber a partir do trabalho (ABBOTT 1990), os espaços de supervisão e a gerência são fundamentais. No entanto, a supervisão individual tende a priorizar a resolutividade, como mencionou um enfermeiro, "não deixar o problema aumentar"; a reunião da equipe privilegia o caso individual e a doença; a gerência da unidade tem uma atuação muito pequena na conformação do trabalho da equipe e do agente.

$\mathrm{Na}$ conformação do trabalho do agente, além das atividades de extensão do trabalho do médico e do enfermeiro na direção da casa e da família, ampliando-se o controle e o cuidado, faz-se a institucionalização de ações comunitárias, como a participação e o controle social. Neste último aspecto, evidencia-se o primeiro passo identificado por WILENSKY(1970) para a profissionalização de uma ocupação. Conforme identificado no depoimento de alguns agentes, o trabalho antes voluntário torna-se remunerado e em tempo integral, respondendo a uma necessidade socialmente colocada.

Identifica-se, ainda, tanto um investimento na capacitação dos agentes, com ampla produção de material educativo pelo Ministério da Saúde, como uma relativa similaridade nas respostas dos agentes quanto a motivações, expectativas, relações com os demais membros da equipe de saúde e com a população. Portanto, nesse estudo pôde-se acompanhar a construção de uma coesão de grupo e identificar passos de profissionalização.

Além desse aspecto, tanto as corporações como os membros da equipe diferenciam o que o agente faz e o que não faz. Ele faz levantamento de informações, comunicação e orientação; ele não faz procedimentos reservados ao trabalho do auxiliar de enfermagem ou ao enfermeiro e ao médico. Do ponto de vista da valorização das suas atividades em comparação com a dos outros, como se identificou, apesar do destaque dado aos agentes (como o diferencial do PSF), dá-se ênfase aos 
aspectos negativos, ou seja, o que ele não faz. Esse aspecto é reforçado nas falas e nas queixas dos agentes.

Nas entrevistas, pôde-se levantar como principais motivações para o trabalho, de um lado, a possibilidade de um trabalho remunerado; de outro lado, o contato com a população concebida como carente, traduzido principalmente pela "ajuda"; e ainda o aprendizado e, para alguns, a perspectiva de profissionalização no campo de trabalho da enfermagem. A profissionalização não só representa maior salário, mas também o apoio em um saber legitimado e o reconhecimento social. Quanto ao significado do seu trabalho destaca-se a solidariedade, traduzida pelo "sentir-se prestativo", destacando-se a faceta humanística (um dos destaques da estratégia PSF) que, às vezes, tende para o messianismo. As facetas de controle e de transformação social não se destacam no trabalho dos agentes e equipes observados, embora estejam contempladas no discurso de alguns dirigentes mais distantes da prática concreta dos agentes.

No plano objetivo do programa, o agente se vê como organizador de acesso (cadastrador e orientador do uso de serviços) e "olheiro" da equipe na captação de necessidade, identificação de prioridades e detecção de casos de risco para intervenção da equipe.

Como as ações previstas não se desdobram em formas mais definidas de atuação, o agente tem a impressão de relativa autonomia, não técnica porque não detém o saber da sua atividade, como o médico (SCHRAIBER 1993), mas relativamente livre nas conversas com as pessoas e famílias visitadas e, especialmente, nas ações comunitárias, onde se destacam as iniciativas individuais (como no cuidado com o lixo) ou coletivas (como na organização de eventos e, por exemplo, na produção da multimistura, na organização do time de futebol).

Entre os agrupamentos - população, agentes e equipe de saúde — os agentes tendem a se diferenciar da população, apesar de moradores na mesma área e cadastrados pelo PSF, sentindo-se, em algumas situações, mais próximos da equipe de saúde. Mas se eles estão apartados relativamente da população, também, ainda, não estão inseridos na equipe. Por outro lado, ao estarem entre a equipe e a população, conformam um grupo próprio, com motivações, desempenhos e opiniões acerca do trabalho comuns. Portanto, seu vínculo é móvel e a identidade, ambivalente. 
Se a sua função e vinculação são múltiplas e, necessariamente, articuladas, pode-se pensar, hoje, os agentes comunitários de saúde como uma ocupação síntese, o trabalhador genérico identificado por NOGUEIRA (2000).

O estudo do padrão de desempenho do agente comunitário de saúde do QUALIS associado às opiniões sobre o seu trabalho emitidas tanto por eles, quanto pelos demais sujeitos do Projeto, possibilitou ampliar a abrangência da compreensão do seu perfil ocupacional-social, a partir das categorias de análise definidas: agente institucional e agente da comunidade.

A categoria agente institucional pode ser entendida como aquele perfil que, na prática cotidiana, expressasse um predomínio de preocupações com as exigências advindas de sua dimensão de agente inserido em um sistema de saúde. Por seu lado, a categoria agente de comunidade manifestaria, como padrão dominante, a solidariedade com o seu grupo de origem e as demandas do bem estar da população. A identificação, por sua vez, expressaria um movimento de adesão ao correspondente pólo de intervenção da proposta: o primeiro mais ao técnico, o segundo, mais ao político.

Como resultado da análise e das discussões que se fizeram, até o momento, com base no material disponível, não se observa no perfil do agente comunitário de saúde uma regularidade ou identificação contínua com qualquer das duas categorias de análise propostas. O que se observa é que essas categorias aparecem nas dimensões do seu perfil incorporadas em determinados momentos do seu trabalho, na dependência das condições objetivas em que se realiza, associadas a suas concepções sobre o seu trabalho, sobre a sua identidade e sobre as organizações envolvidas: a instituição e a comunidade.

Em outros termos, a análise orientada para os dois pólos, o agente institucional e o agente de comunidade, revelou a convivência de dois pólos de movimentação que, na realidade, são pólos de tensão, dos quais não se evidenciam tipos “puros”, porquanto entre os quais desenvolve-se um gradiente de possibilidades. Evidenciou-se que, em diferentes situações, ele pende mais para um pólo, ou mais para o outro. Face a determinada situação concreta, ele se encaminha mais para o pólo institucional e, frente a outras, ele se encaminha mais para o pólo comunitário. Essa dubiedade é também evidenciada nos seus depoimentos, bem como nos dos seus colegas de trabalho. 
Se a identidade do agente não é exclusivamente pendente para um dos lados, esse pender é mais freqüentemente para o pólo técnico, aquele das ações da instituição e da assistência ao indivíduo, como evidenciado pela maior concentração das atividades desse tipo. A equipe, na sua função de gerência da proposta, envolvendo a supervisão do médico e do enfermeiro, e mesmo o trabalho formal do gerente da unidade, parece pouco ver as atribuições desses dois pólos ou orientar mais um ou outro.

Essa constatação coincide com os achados na literatura, onde o agente aparece, nas diferentes propostas, como um personagem fruto de uma tentativa de juntar as perspectivas da atenção primária e da saúde comunitária, buscando resolver dimensões, como o acesso aos serviços, no que lhe corresponde de racionalidade técnica, mas também integrando as dimensões de exclusão e cidadania, ou seja, o pólo técnico e o pólo político das propostas.

Ao incorporar essas duas dimensões em suas formulações, o conflito torna-se inevitável, principalmente na dinâmica da prática cotidiana. Determinados programas acabam dando mais espaço para um ou para o outro pólo. Nenhum dos programas de saúde da família elimina esses dois pólos, que estão colocados como dimensões de tensão explícita. Essa característica torna-os diferentes de um pronto socorro, de um pronto atendimento, por exemplo, pois, embora havendo, também nesse último, a dimensão de conhecer as pessoas, da humanização, que isso seja importante para a efetividade e o encaminhamento da conduta, o que se espera, nuclearmente, são atos médicos corretos, que os profissionais médicos tenham CRM, ou seja, o compromisso profissional está muito claro para os clientes e também para os próprios profissionais.

Por outro lado, no tipo de programa em análise, a identidade dos sujeitos do trabalho não se evidencia como muito clara. Na prática do dia-a-dia, eles têm que dar conta das contradições sociais, o que é "muito pesado" e, por isso, eles fazem determinadas opções, segundo as exigências e as recompensas e suas referências.

Os dados indicam que o agente comunitário, seja mais próximo do pólo institucional ou do comunitário, não dispõe de instrumentos, de tecnologia, aqui incluídos os saberes para o seu trabalho. Essa insuficiência faz com que ele acabe trabalhando com o senso comum, com Deus e, mais raramente, com os saberes e os recursos das famílias e da comunidade. 
Nesse sentido, e retomando o referencial utilizado para análise dos dados, esse agente não teria elementos de identidade bem claros, dificultando quer o sentimento de pertencer a um grupo, quer as regulações profissionais, entre pares. Há saberes de empréstimo no pólo técnico, mas não há propostas ou trabalho consistente do "agir comunicativo", embora as ações de conversa sejam usadas.

\subsection{O AGENTE COMUNITÁRIO DE SAÚDE DO QUALIS E OS AGENTES DE} PROPOSTAS ANTERIORES: analogias e especificidades

Como argüiu Foucault (1981), o que mudou no olhar, na forma de apreensão e perspectiva de atuação?

Situação 1. Atendimento num posto de saúde rural do PIASS no Vale do Ribeira, SP.

(Menino, 9 anos - 7:00h)

Mãe: $\quad$ Trouxe o menino, que esta noite começou a gritar de dor de estômago. E os irmãos também estão doentes.

Agente: $\quad$ Mas é fome! Não é doença! O Gestal que eu dei já acabou?

Mãe: $\quad J a ́$. Os meninos tomaram. Eles só se alimentaram disso. Eu saio cedo e esse menino fica cuidando da casa e dos irmãos. Ele lava, puxa água do poço, cuida deste pequeno (9 meses), cozinha alguma coisa...

Agente: $\quad$ Esses meninos estão fraquinhos demais! $O$ maior precisa ficar mais forte para eu poder dar lombrigueiro, que vai deixá-lo com mais disposição. A senhora vai levar esses 2 comprimidos de remédio (Buscopan, drágeas) e dar pra ele hoje e amanhã à noite. Vai levar Gestal (5 pacotes) e dar 3 copos por dia. Prepara bem forte, pra todas as crianças. Toma bem hoje e amanhã, e na sexta-feira dá o lombrigueiro pro J., que essa dor no estômago devem ser vermes. Agora o lombrigueiro (Thiaben), não dá o vidro de uma vez: vai dando aos poucos durante o dia. Tenho certeza que vai servir pro tipo de verme que o J. tem. Depois vem aqui buscar mais vitaminas desta (Polivitamínico, líquido), que o J. vai tomar até acabar o vidro. Agora, precisa arranjar um jeito de alimentar melhor essas crianças!

Mãe: $\quad$ Eu já disse pro meu marido que a gente precisa sair daqui, senão a gente vai perder todos eles.

Agente: $\quad$ Quanto dá pra tirar com o chá?

Mãe: $\quad 7.000$ por quinze dias.

Agente: $\quad$ Mas só isso? Pra alimentar cinco crianças e cinco adultos?

Mãe: $\quad$ Que se vai fazer?

(A agente vai até a própria casa e volta com um saco de pão, dando-o para a mãe).

Agente: Toma. Leva esses pães pras suas crianças. Porque você não levas essas crianças pra creche? Lá elas comem sopa o dia todo.

Mãe: $\quad$ Mas eu tenho tempo? E a colheita do chá? Esse desgramado chá mata a gente o dia todo no calorão.

Agente: $\quad$ Ai, mulher... dá um jeito na vida! 


\section{(A mãe sai com os filhos, levando gestal, Buscopan, Thiaben e um saco de pão)}

\section{Situação 2. Visita domiciliar - QUALIS São Paulo}

Agente: Oi, tudo bem? E os bebês (gêmeos)?

Mulher: $\quad$ Tudo bem. Eu estou levando eles lá no Patriarca e eles estão sempre estressados, a médica... Ah, eu desisti (do Posto do QUALIS). Outro dia eu passei lá com a ... (enfermeira)..., outro dia que eu marquei telefonaram desmarcando... outro dia precisei de remédio e também não tinha.

Agente: $\quad$ E o que o Patriarca te oferece que aqui não tem?

Mulher: $\quad$ Não precisa marcar: eu vou lá e eles me atendem... Aí eu achei útil

Agente: $\quad$ Olha dia 4 nós faremos um atendimento especial para crianças.

Mulher: $\quad$ Ah! Sabe aquela enfermeira ... (descrição fisica) ela é estúpida. Eu falei que precisava falar com ela e naquele momento chegou uma funcionária com a filha. Ai ela foi logo atendida... achei sacanagem. Ai eu precisei outro dia... ele estava com febre.... a moça mandou ir para o Inhocunhé. Puxa vida, olha, só você (nome da agente) que resolve, sabe?

Agente: $\quad$ Me dá outra chance, vamos marcar agenda para a ... (criança) e vamos tentar, está certo? Você está vacinando ela direitinho?

Mulher: Estou. Olha, eu mesma que faço o controle dela em casa porque a enfermagem lá não deu certo. Só com você que deu certo. Outro dia o ... (criança) ficou com febre e eu fiquei arrasada: a gente mora perto do posto e não pode atender, sabe? Aí eu fui para o Patriarca.

Agente: Olha, eu quero o melhor para vocês. Toma sua consulta. Não fica triste, não desanime. Eu volto para saber o que deu, está bem?

Mulher: $\quad$ Ah! A enfermeira falou que quando eu precisasse de lá eles não iriam ajudar... que se eu quisesse, procurasse o Patriarca. Olha, fiquei triste! (Agente entrega um papel) É o Programa do Leite?

Agente: $\quad$ É lá na Igreja...

Mulher: $\quad$ Ah! É muito cheio, o negócio é muito complicado...

Agente: $\quad$ Tá vendo! Você tirou o peito da ... (criança)...

Mulher: Não, eu não tirei não: as crianças estavam chorando de fome e o peito já não está suficiente. Vê o ... (remédio) para mim?

Agente: $\quad$ Vou ver se tem. Eu providencio para você, viu?

Mulher: $\quad$ Tá bom, (nome da agente). Desculpe aí.

Agente: Tchau.

Essas duas situações de trabalho são bastante ilustrativas de momentos e dimensões diversas e, ao mesmo tempo, análogas, de realização de pólos diferenciados de dois diferentes Programas, e da participação do agente, em contextos também diversos. A simples leitura possibilita a apreensão de como acontece o trabalho dos agentes, sua complexidade, seus receios, suas incertezas, seus limites, a expectativa de uma identidade, sua solidariedade. 
Trata-se, nesta parte da Discussão dos Resultados, de confrontar as características predominantes identificadas no perfil ocupacional/social do agente comunitário de saúde do QUALIS, com informações análogas sobre os agentes de outros programas implantados no país.

Cabe ressaltar os limites a que está sujeito esse procedimento, na medida em que as diferentes fontes utilizadas para a coleta de dados, que permitiram a apreensão de características dos programas e agentes - matéria prima para a comparação - não guardam entre si uma identidade em termos de abordagem do tema ou de objetivos para os quais foram editados. Assim, à riqueza do material utilizado, contrapuseram-se, em termos de limites para uma abordagem mais analítica na direção requerida por este trabalho, as diferentes ênfases atribuídas aos diversos aspectos do objeto em estudo. Por esse motivo, serão alguns os aspectos analisados; pela mesma razão, a comparação, em determinados momentos, será feita, principalmente, entre os agentes do QUALIS e os do Vale do Ribeira, até pela similaridade da metodologia utilizada para a coleta e a análise dos dados.

Conforme detalhado na Introdução deste Trabalho, foram os seguintes os Programas considerados para a referida comparação: o PIASS Nordeste; o PIASS do Vale do Rio Ribeira, em São Paulo; o Programa de Agentes Comunitários de Saúde do estado do Ceará; o Programa de Agentes Comunitários de Saúde, do Ministério da Saúde e o Programa de Saúde da Família do Ministério da Saúde. Dessas propostas, resgataram-se aspectos que se consideraram centrais para os objetivos da Tese, em especial referentes à população a que se destinava, inserção do Agente na proposta e expectativa de impacto de suas ações, ações propostas para desenvolver, interação e relacionamento com a estrutura profissional, espaço de atuação, autonomia de decisão, interação com outros profissionais, interação com a estrutura organizacional, concepção sobre sua identidade como agente, interação com a comunidade e concepção sobre a importância do seu trabalho para a população.

Esses aspectos foram analisados à luz dos conceitos e teorias, o que possibilitou a apreensão e a compreensão de características, em diferentes contextos. Face à articulação e à complementaridade entre os diferentes aspectos na conformação de um perfil ocupacional/social, a discussão, para algumas características, será desenvolvida em conjunto. 
O pressuposto central que embasou essa comparação foi o da determinação histórica e social dos conceitos e das práticas em saúde e, por conseqüência, a conformação e designação dos seus sujeitos. Assim, a idéia essencial é que aquele elemento que promove uma ligação entre a comunidade e algum sistema de saúde, que viabiliza uma política, não é e nem será o mesmo, nos diferentes momentos históricos e regiões para as quais foi proposta a sua participação. Do mesmo modo em que houve variações em relação à concepção, à expectativa de impacto de suas ações, o seu perfil também as teve, tanto nos aspectos das ações, quanto no que existe de interação e, por conseqüência, na identidade.

\section{Principais aspectos - analogias e especificidades}

A referência a populações carentes e marginais ao processo produtivo é, praticamente, unânime e, quando não é explicita, essa condição é facilmente inferida dos textos que justificam os programas. No começo, apenas para habitantes de áreas rurais, até para mantê-las no campo e ultimamente para as periferias de centros urbanos. Não há indicações de que esses programas tenham sido diretamente dirigidos para a população economicamente ativa, até pela organização da oferta de serviços, mas talvez funcionem como suporte social aos membros da família. Embora, por exemplo no caso do QUALIS, não se consiga encontrar uma justificativa explícita de interiorização das ações de saúde, de extensão de cobertura, a proposta é, evidentemente, de ampliação do acesso.

Cabe referir que não foram encontradas evidências, nos depoimentos nem nos documentos consultados, de justificativa ou fundamentação das propostas pelo lado de contribuição para a reprodução da força de trabalho. A sua validação aparece sempre como garantia de acesso, tanto nas dimensões racionalizadoras quanto nas de inclusão, de cidadania.

A partir de 1988, a identificação desses programas como estratégia de alcançar os princípios do SUS - a integralidade, a universalidade, a eqüidade, tendo como eixo de sustentação o acesso - parece hegemônica. Uma explicação inicial pode residir no fato de que, no início de sua proposição, o agente, nas propostas de medicina comunitária e dos programas de extensão de cobertura, tinha por função muito mais o alívio de tensões sociais em relação a populações marginais ao processo de produção (II PND 1975; DONNANGELO 1979). 
Mesmo quando se indicam zonas urbanas, em regiões metropolitanas, são lembradas as características de heterogeneidade; não é o fato de se implantar em áreas metropolitanas que a população alvo seria diferenciada. Exemplo disso são as características das áreas atendidas pelo QUALIS, em São Paulo, identificadas pelos indicadores de Inclusão/Exclusão indicados no Capítulo 3, de Métodos.

Essa característica da população que atendem, como "carente", é reconhecida pela maioria dos agentes. Aliás, nas entrevistas, tanto os agentes do Vale quanto os do QUALIS, atribuem aos moradores das regiões onde vivem e trabalham, a condição de "carente" e necessitada dos serviços que o Programa oferece. Em determinadas situações, alguns agentes já se expressam como se não estivessem mais incluídos naquele grupo social.

As ações desenvolvidas pelos agentes, e a expectativa dos outros membros da instituição em relação a elas, embora representem o grande diferencial entre os Programas, colocam-se, em geral, como abrangendo quatro conteúdos:

- $\quad$ A atenção básica em saúde, aí incluídos o atendimento a problemas prevalentes, a educação para a saúde

- $\quad$ A vigilância à saúde, o monitoramento de grupos de risco, o controle de doenças transmissíveis,

- $\quad$ A atuação intersetorial

- $\quad$ A organização da comunidade

Em algumas das propostas analisadas, ao lado da atenção básica, colocam-se atribuições de atendimento em casos de urgência e de primeiros socorros.

A ênfase dada a cada um desses conteúdos, ou à relação entre eles, é o que garante a especificidade, pois tem variado de proposta para proposta, na dependência das realidades das populações a que se destinavam e das condições de contexto. Em outras palavras, a definição das atribuições tem sido um dos resultados mais efetivos das negociações locais, segundo as suas realidades, aí consideradas as necessidades expressas pelos indicadores mais simples, a oferta de serviços e de recursos humanos.

Por outro lado, ainda abordando as ações do sujeito, sua abrangência e a expectativa de suas ações, em praticamente todas as propostas, com graus variados da ênfase colocada, conseguem-se identificar dois componentes principais: um primeiro que se poderia considerar como mais estritamente técnico, relacionado ao atendimento aos indivíduos e famílias, a intervenção para promoção da saúde ou para o 
monitoramento de grupos ou problemas específicos. Ao lado desse, um componente que se identifica como político, não apenas de solidariedade à população, de discutir saúde no contexto geral de vida mas, também, no sentido de organização da comunidade, de transformação dessas condições. Esse componente político expressa, na dependência da proposta considerada, duas expectativas diversas, ou complementares: o agente como um elemento de reorientação da concepção e do modelo de atenção à saúde, de discussão com a comunidade dos problemas de saúde, de incentivo ao auto-cuidado - dimensão mais ético-comunitária - ou o agente como fomentando a organização da comunidade para a cidadania, a inclusão, a transformação social. Essa é uma dimensão importante e diferenciada que se identifica, como expectativa para os agentes, nas entrevistas com os responsáveis pelo Projeto DEVALE e também, em algumas situações, do Projeto QUALIS. Por outro lado, uma dimensão, bastante encontrada na prática, de maneira incipiente, dimensão essa não relacionada nas atribuições dos agentes de nenhuma das propostas, é a dimensão de assistência social. Entre os 17 agentes para os quais se aprofundou o estudo da prática, 6 expressaram, por ocasião da entrevista, desejo de prosseguir estudos: 3 para auxiliar de enfermagem, 2 para Psicologia e um deles, de formar-se em "assistente social".

Uma outra consideração necessária acerca das ações dos agentes, das expectativas e possibilidades de realização, refere-se à relativa dificuldade ou pequeno número de oportunidades em que se observou, quando da avaliação da prática desses sujeitos, no Vale do Ribeira e no QUALIS, a prática de medidas preventivas, de ações de natureza educativa para a prevenção de doenças. A relação dessas evidências com outros aspectos poderá ser identificada através de estudos posteriores.

NOGUEIRA et al. (2000) identifica no trabalho do agente a dimensão tecnológica e a dimensão solidária, social, as quais considera que têm, sempre, potenciais de conflitos. Essas dimensões expressam, possivelmente, por sua vez, os pólos político e técnico do Programa. A perspectiva individual de cada um nem sempre corresponde à perspectiva tecnológica, da racionalidade, ou seja, os pólos não convivem harmonicamente. Essa é a questão do médico no pronto atendimento, ao qual já se fez referência. O agente, entretanto vive isso, de uma forma completa., durante todo o dia, todo o seu trabalho. Então, o trabalho do agente, com essas duas dimensões, é sempre de conflito. Essa é a discussão do acolhimento. Há milhares de pessoas... a angústia delas é igual. Como priorizar, o que é mais importante? Baseado 
na racionalidade, diz, deve ser atendido quem tem mais risco de morte, de complicação. $\mathrm{Na}$ dimensão da solidariedade, todos devem ser atendidos, todos têm direito. Se houvesse como medir o grau de desespero, entraria quem estivesse mais desesperado.

Esse é o dilema permanente do agente, essa dimensão social, solidária, convivendo com a dimensão tecnológica. Para essa função social, dado que nós somos uma sociedade que valoriza o conhecimento, a sua identidade profissional, essa dimensão do trabalho do Agente, não estando construída, ela, em termos de mercado de trabalho, em termos de venda da força de trabalho, quase não se coloca. Essa dimensão é muito importante em termos da realização de políticas, mas não tem valor de troca, no mercado de trabalho. A sociedade atual, tecnológica, com um alto grau de complexidade da divisão social do trabalho foi acumulando exigências e, até por isso, pressupõe a existência de uma identidade ocupacional ou profissional.

Quando o agente se refere ao seu trabalho, nas entrevistas, parece abordá-lo na perspectiva de uma atividade; não se identificando, numa primeira análise, uma clareza de inserção desse trabalho, no mercado formal. E tanto ele tem dificuldade em caracterizar isso como trabalho, que ele pensa em fazer o curso de auxiliar de enfermagem; manifesta, em várias ocasiões, que o profissional é o auxiliar.

\section{- A relação com a organização profissional vigente - a pressão dos grupos profissionais}

A partir do estudo do conceito de profissão, a partir das teorias que enfatizam a dimensão técnica da formação, ou seja, do conhecimento esotérico como essencial para caracterizar um profissional, consegue-se discutir questões como: o profissional de uma determinada categoria é sempre igual, o médico é sempre igual, o enfermeiro é sempre enfermeiro; por conseqüência, o agente de saúde tenderá a ser sempre igual, qualquer que seja o contexto. Por outro lado, outras teorias, das quais, entende-se, o FREIDSON mais se aproxima, consideram que a dimensão profissional do saber, do conhecimento existe e é muito importante até na autonomia profissional, mas que ao saber deve ser acrescida a estrutura da produção, na determinação de uma prática profissional. Numa outra abordagem, a conceituação de profissão na saúde tem que incorporar a discussão do trabalho, da organização do trabalho sobre as relações sociais de produção, as necessidades de saúde e também a organização do sistema de saúde, de uma dada realidade, onde essas propostas devem realizar-se. 
Isso posto, considera-se que, na área da saúde, algumas profissões, no entanto, são mais estáveis: têm maior grau de autonomia profissional, considerada, essa autonomia, na sua dimensão técnico-científica, como é o caso do médico. O agente de saúde, em primeiro lugar, não é um profissional, ainda. Por outro lado, discutiu-se, atrás, uma determinada "autonomia" do agente comunitário de saúde do QUALIS - o que pode parecer contraditório - relacionada, possivelmente, até com a ausência de um saber, um saber operativo específico; o agente aparece, na maioria das situações observadas, como executando um conjunto de tarefas definidas segundo uma lógica não apoiada apenas na racionalidade técnica. Às vezes, uma tarefa se justifica por si própria; não se identifica com o alcance de uma finalidade previamente determinada. $\mathrm{O}$ trabalho dele é freqüentemente interrompido, como ele, inclusive refere, por prioridades outras, como desmarcar e remarcar agendamento, ou fazer levantamento de novas informações.

As negociações para a regulamentação da profissão de agente comunitário de saúde, no país, no âmbito do Poder Legislativo, têm sido objeto de várias pressões e, por conseqüência, de Projetos de Lei na Câmara dos Deputados. Apenas de 1993 a 1999, foram apresentados seis Projeto de Lei (Anexo 5.1). Os projetos mais recentes que dispõem sobre o exercício da profissão de ACS (o PL 357 de 1999, apensado ao PL 86 de 1999) estabelecem exigências como a que este só poderia exercer suas atividades em ambiente externo (nas comunidades) estando-lhes vedado o trabalho em instituições de saúde - serviços ambulatoriais, hospitalares, laboratórios ou em setores administrativos, mesmo de unidades de saúde; a exigência de escolaridade mínima correspondente à $4^{\mathrm{a}}$ série do primeiro grau; a obrigatoriedade de apresentação de certificado de conclusão de formação básica em saúde comunitária; a comprovação de ter residência fixa na localidade de trabalho.

Na justificação apresentada para a regulamentação da ocupação destacam-se:

- a idéia da igualdade de tratamento com outras ocupações;

- considerações relativas à ampliação do acesso aos serviços básicos de saúde. Argumenta-se que a regulamentação da profissão de agente comunitária ampliaria o acesso aos serviços de saúde especialmente para as comunidades mais carentes do país.

- A garantia de uma proteção social mínima a esses trabalhadores - uma questão de justiça, pode-se dizer - uma vez que não obstante sua função estratégica na 
reversão do atual modelo assistencial, "eles permanecem como trabalhadores informais, sem as mínimas garantias trabalhistas (sendo) muitas vezes tratados com trabalhadores temporários" (Câmara dos Deputados, PL 357 - 1999, p. 4).

Anteriormente, o Projeto de Lei 3.994 de 1993, de autoria do Deputado Paulo Portugal, estabelecia a denominação Agente de Saúde Comunitária com as seguintes competências: atendimento às comunidades, particularmente as mais carentes, ministrando conhecimentos sobre prevenção de doenças e prestando atendimento em primeiros socorros, imunização, cuidados primários e vigilância epidemiológica. Como pré-requisito fixava o primeiro grau completo e formação básica em curso de agente de saúde comunitária. Nada se falava sobre a proibição de sua atuação no âmbito dos serviços ambulatoriais, hospitalares ou nos serviços burocráticos, quer dizer, das instituições de saúde.

A mesma denominação e a mesma redação tem o Projeto de 1995 apresentado por Augusto Viveiros. Nessa altura, o relator do Projeto, Deputado Sérgio Arouca emite parecer favorável pela aprovação do projeto na forma de um substitutivo com as seguintes alterações. Em primeiro lugar, sugere a mudança de denominação de Agente de Saúde Comunitária para agente comunitário de saúde que "representa melhor o tipo de atuação exercida pelos mesmos" (p.4): trabalhando em comunidade; em segundo lugar, a escolaridade mínima é reduzida para a $4^{\mathrm{a}}$ série do primeiro grau, "pois a maior parte dos agentes já existentes são oriundos de estratos mais pobres ... onde não tiveram, por razões diversas, possibilidade de conclusão do primeiro grau ..."; em terceiro lugar, a modificação mais substantiva que não aparece no texto do parecer mas apenas no substitutivo: determina-se que o exercício das atividades do agente comunitário de saúde "ocorrerá exclusivamente em ambiente externo, sendo vedada atuação nos serviços laboratoriais, ambulatoriais ou hospitalares ... ".

As versões posteriores do Projeto, sem exceção, incorporam as modificações sugeridas no substitutivo de Arouca (PL 4.868 de 1998; PL 86 de 1999 e PL 357 de 1999).

Uma característica que envolve todos esses Projetos de Lei é a preocupação com aspectos trabalhistas da inserção dos agentes de saúde: carga horária, remuneração. Um desses projetos chega a propor 30 horas semanais para o agente, com remuneração de horas extras, o que evidencia um trabalho importante nesse cenário, por parte de entidades de atuação correspondente. Ao mesmo tempo, nos 
mesmos projetos, identifica-se uma incapacidade de definir o que seja o saber próprio, particular a essa "profissão".

As idas e vindas em termos de exigências para a profissão, as restrições de exercício institucional dos ACS estiveram provavelmente vinculadas a pressões das entidades da área de enfermagem, preocupadas com um possível retorno e acirramento da problemática dos atendentes de enfermagem, como também na tentativa de preservar um exercício sob a sua jurisdição. Cabe, inclusive, considerar o aspecto relacionado com a referência e a supervisão para os agentes, em relação ao qual não havia consenso: se caberiam essas funções ao enfermeiro ou a outro profissional de nível superior.

Quanto à aproximação da prática do agente ao exercício de uma profissão já regulamentada, no caso, a enfermagem, nesse ponto, considera-se, reside uma das principais diferenças do QUALIS, na medida em que nas suas atribuições, ou menos ainda, na sua prática, não foram identificados aspectos que caracterizem ações de enfermagem. Essa informação confirma uma das premissas colocadas no começo deste trabalho: em sociedades mais estruturadas, caracterizadas por um sistema de saúde mais complexo, por uma organização profissional estruturada, por um mercado de trabalho já regulamentado, a presença/inserção de um trabalhador de saúde sem uma referendada qualificação profissional obedece a determinados limites em termos de perfil, competências e organização tecnológica do trabalho. No caso específico do Agente de Saúde, historicamente, como se viu, sempre ocorreu uma disputa em termos de jurisdição, de espaço de atuação com o pessoal de enfermagem, mesmo que o agente não atuasse sob essa jurisdição. No caso do QUALIS, freqüentes são as circunstâncias que suscitam a necessidade de discussão, tendo em vista a prática dos agentes.

Assim, em São Paulo, em poucos momentos, identifica-se, na dimensão da atenção básica, uma aproximação do agente de saúde do QUALIS dessa concepção e prática do cuidar na perspectiva assumida pelos profissionais da enfermagem, Nas entrevistas, entretanto, em relação a essa dimensão, poucos são os enfermeiros que a referem e os auxiliares de enfermagem, em sua maioria. Já em outros Programas, em outras regiões do país, essa dimensão é colocada como necessária para cumprimento dos objetivos.

Em síntese, ainda que se identifiquem aspectos comuns entre todos, cada contexto introduziu, certamente, diferenças importantes em cada um dos Projetos. A 
negociação local, o contexto, os outros sujeitos e a sua relação, consideram-se as condições mais importantes.

\section{- A relação com a sociedade, a realização dos pólos}

Há evidências de que, em praticamente todas as propostas, é atribuída ao agente de saúde a função de viabilizar determinadas dimensões de uma política de Estado, sendo dimensões importantes, a proposta de ação intersetorial e o elo com a participação popular. Assim, o transitar entre os pólos político e técnico é uma fonte permanente de conflitos para o agente, em quaisquer dos Programas que se considere, embora com distintos matizes.

O dilema do agente no relacionamento com a população, e com a instituição, o agente de comunidade ou o agente institucional, parece ser um processo comum a todas as propostas que se propuseram a trabalhar com o agente como representante do seu grupo de origem, a comunidade. Quanto aos fatores que condicionam essa situação, poderíamos aqui lembrar NOGUEIRA et al. (2000), quando afirma que "o papel que o ACS exerce na relação com a comunidade tem que ser contemplado com prioridade na sua caracterização, que abrange dois aspectos fundamentais: a) identidade com a comunidade; e b) pendor para a ajuda solidária" e que, até por isso, "as alternativas de vinculação institucional têm que ser ajuizadas considerando igualmente o quanto elas podem facilitar ou dificultar o cumprimento pelo ACS do seu perfil social" (Nogueira et alii 2000, 12). SILVA et ali. (1986), acerca desse assunto, considera a origem do agente, suas condições de acesso a serviços de assistência médica, a cultura hegemônica, o espaço para a crítica e o tempo necessário para emergir essa crítica.

Um aspecto que, pode-se considerar, representa, evidencia e promove uma semelhança entre todos os agentes, de quaisquer dos programas e ou contextos considerados: a satisfação por estarem desenvolvendo um trabalho que consideram útil e a sensação de orgulho quando constatam que o seu esforço é reconhecido pela comunidade e pela instituição, organizações às quais, eles entendem, devam dar satisfações acerca do seu trabalho.

Para encerrar este capítulo, apresenta-se uma situação, bastante ilustrativa do relacionamento com população, das expectativas da população e do próprio agente 
sobre o trabalho e quem sabe, de um caminho que, em outro contexto, talvez valha a pena ser tentado...

\section{Vale do Ribeira, 1983 - informações a partir da análise das transcrições das fitas em que foram gravadas as sessões de treinamento dos agentes.}

Aluno: "Uma senhora que me vê todo dia pegar o ônibus para vir para cá, perguntou como é que ia o negócio do treinamento, o que a gente estava aprendendo, se estava mexendo com remédios, essas coisas ... Eu disse a ela que a gente estava batendo um papo, cada um falando dos problemas de saúde do seu bairro ... e a conversa estava entre eu e ela mas, de repente ... outra que eu não conheço, que estava sentada, fala para mim: - "escuta: se um dia eu tiver um filho meu ruim lá no postinho, você vai ficar me perguntando negócio da terra, se fulano tem terra, se tem esgoto na rua, ou vai procurar socorrer o meu filho?" Nisso eu parei ... Se ela tivesse vindo com jeitinho, sei lá ... , eu pensava no que responder, não é? Mas eu estava num meio onde não conhecia ninguém, nunca vi essa mulher pela frente ... Eu não sabia o que responder, eu fiquei sem graça, eu baixei a cabeça e larguei a mulher falando sozinha."

O problema foi lançado pelo instrutor para o grupo:

"Como é que a gente vai enfrentar numa situação dessas? A gente vai decidir só aprender a aplicar injeção, dar remédio, e assim contentar as pessoas que pensam assim, e tudo bem? Como é que vamos resolver esse problema?"

Muitos alunos, nessa oportunidade, opinaram sobre como encaminhar e resolver a questão. Colocaram situações semelhantes com que se tinham defrontado em seus bairros. Em alguns, ao contrário do episódio com $\mathbf{A}$, o pessoal estava achando muito útil o conteúdo do curso; já outros relataram casos de moradores que achavam que em dois meses os agentes não iriam aprender nada.

Após muita discussão, um agente sintetizou o que o grupo havia concluído: o futuro agente teria que resolver o(s) problema(s) respondendo às pessoas com o seu trabalho na comunidade. A par disso, no seu dia-a-dia, teria como tarefa individual conversar com o povo para esclarecê-lo sobre a relação dos vários fatores com a saúde (SILVA, 1984). 


\section{CONCLUSÕES}

A partir da apresentação do conjunto do trabalho, da identificação e síntese dos principais resultados, considerou-se a necessidade desse último capitulo ter o caráter predominante de considerações finais, as quais incluíssem os principais desafios que, durante o desenvolvimento do estudo, emergiram como importantes, no sentido de garantir o acesso e a cidadania tanto à população das regiões cobertas pelo QUALIS, quanto ao principal sujeito referido de sua realização.

No Brasil, o Programa de Saúde da Família pode ser visto como uma retomada de proposições contidas nas políticas públicas federais que estiveram em evidência, desde meados dos anos setenta, até início dos anos oitenta, como o modelo PIASS e o Programa Nacional de Serviços Básicos de Saúde ( $7^{\text {a }}$ Conferência Nacional de Saúde 1982), e que visavam à extensão da cobertura e à ampliação do acesso a serviços de saúde para grupos sociais ainda marginalizados, moradores em regiões de baixa densidade populacional, ou pequenos centros urbanos da Região Nordeste, com condições de saúde muito precárias. Apesar do restrito impacto efetivo dessas políticas, de certa forma, pode-se considerar que elas tiveram alguma continuidade em iniciativas de âmbito regional ou local, e que se traduziram em programas de tipo Agentes Comunitários de Saúde, proposta essa encampada pelo Ministério da Saúde como programa nacional, o PNACS, em 1991 (Jatene et al.1999).

Atualmente, esse tipo de Programa encontra-se em fase de expansão, tanto em áreas rurais como em áreas urbanas. Além disso, esses modelos vêm sendo, cada vez mais, implantados em grandes cidades e áreas metropolitanas, mantendo, entre seus pressupostos e estratégias de intervenção básicos, as perspectivas de ampliação do acesso, de racionalidade técnica e econômica, de participação popular em saúde e de extensão de cobertura por serviços de saúde para parcelas específicas da população brasileira. Todas essas proposições básicas, entretanto parecem ter se tornado passíveis de algum grau de recomposição, em nível local, na dependência das características dos grupos envolvidos e dos processos ocorridos em nível central.

Durante toda a trajetória de desenvolvimento deste trabalho, procurou-se compreender o perfil do agente comunitário de saúde do QUALIS, em São Paulo e as mudanças por que passou esse sujeito central da realização dessas propostas de atendimento a necessidades sociais, em específicos momentos históricos, no processo 
de deslocamento de áreas periféricas e rurais para grandes cidades, tendo em vista a apreensão de suas demandas e necessidades em áreas metropolitanas.

O estudo do padrão de desempenho do agente comunitário de saúde do Qualis associado às opiniões sobre o seu trabalho emitidas tanto por eles, quanto pelos demais sujeitos do Projeto, possibilitou ampliar a abrangência da compreensão do seu perfil ocupacional-social - categoria síntese entre a ação e a interação e entre o desempenho e a identidade - a partir das categorias polares de análise definidas: agente institucional ou agente de comunidade, correspondentes, respectivamente à sua possibilidade de realização das dimensões técnica e política das diferentes propostas.

Como resultado da análise e das discussões aqui desenvolvidas, tomando por base o material disponível, não se observa no perfil do agente comunitário de saúde uma regularidade ou identificação contínua com qualquer das duas categorias de análise propostas. $\mathrm{O}$ que se observa é que a correspondência de seu perfil a um agente de comunidade ou a um agente institucional não aparece, como exclusiva, em nenhum momento do seu trabalho. Por outro lado, o que se evidencia, nos diferentes momentos, é um padrão dominante de adesão a um dos pólos, na dependência dos contextos e das condições objetivas em que se realiza, associados a suas concepções sobre o seu trabalho, sobre a sua identidade e sobre as organizações envolvidas: a instituição e a comunidade.

Por outro lado, nos programas de saúde da família, a identidade dos sujeitos envolvidos no trabalho fica menos clara do que nos serviços de saúde "tradicionais", o que é uma fonte permanente de conflitos. Na prática do dia-a-dia, espera-se que os agentes dêem, também, conta de todos os problemas sociais, o que é uma tarefa por demais pesada, levando à necessidade de que sejam feitas opções, que estarão orientadas segundo as demandas, as recompensas e as referências pessoais.

Conforme já se colocou na discussão, os dados indicam que o agente comunitário, esteja mais próximo do pólo institucional ou do comunitário, não dispõe de instrumentos, de tecnologia, dos saberes para o seu trabalho. Essa insuficiência faz com que ele acabe trabalhando com o senso comum, com Deus e, mais raramente, com os saberes e os recursos das famílias e da comunidade.

O que pôde ser evidenciado no estudo - a identidade do agente, a partir de suas referências, constrói-se em situações concretas e na relação com a população e com os demais membros da equipe de saúde - permite a identificação de diversas questões, 
algumas das quais, espera-se sejam objetos de novos estudos, tendo o apoio a demandas e necessidades desse trabalhador na sua função de viabilizar políticas sociais.

Os resultados da análise desenvolvida apontam para um permanente foco de tensão e de conflito entre as duas dimensões de sua prática, para as quais ele foi proposto.

As condições concretas de uma metrópole, com um sistema de saúde estruturado, com a organização profissional definida, com necessidades e demandas sociais mais agudas na periferia, com exigências em termos de definição de identidade profissional, tendem a ampliar as dimensões desse conflito.

A tendência observada mais para o pólo institucional tem, certamente, a ver, entre outros aspectos, com a organização do seu trabalho, com a insuficiência do instrumental tecnológico e de saberes para operar as duas dimensões, com a indefinição do seu perfil e de suas referências, com as insuficientes referências e contatos com as organizações e necessidades da sociedade civil e comunitária e com suas concepções do que é mais valorizado em determinada sociedade.

Assim, se ele tende mais para o pólo institucional, o faz por diferentes motivos, entre os quais a possibilidade de apoio, de reconhecimento social e de referência no que ele considera trabalho e identidade ocupacional.

O fortalecimento de sua referência de saúde como qualidade de vida e de sua vinculação comunitária coloca-se, em termos de conclusão deste trabalho, como muito importante.

Tendo em vista as análises desenvolvidas neste trabalho, considera-se a necessidade da definição do seu referencial no dia-a-dia do trabalho, para o planejamento e a reflexão sobre os resultados e para que o trabalho não dependa do bom senso de cada um. A ele não podem ser atribuídas, pessoalmente, essa responsabilidade e essa competência.

Nesse sentido, coloca-se a garantia de condições para que ele construa um saber operante para as duas dimensões de realização do seu perfil ocupacional-social, e, por conseguinte, do objetivo da relação estado-sociedade nessa perspectiva específica - tanto na vertente tecnológica, que, entretanto, supere a dimensão exclusiva da clínica mas, principalmente, na vertente social e comunitária. 
O padrão de trabalho observado é, em geral, conseguido graças ao empenho, à dedicação e ao compromisso de que é portadora a grande maioria dos agentes. As iniciativas que desenvolvem em relação aos indivíduos, exemplo, o clube de futebol, a capoeira; em relação às famílias e à comunidade - o galpão comunitário, a rádio comunitária - são, muitas vezes, expressão de um compromisso fora do comum, de uma solidariedade que necessita de um apoio, de uma institucionalização.

Quando o agente diz, em determinado depoimento, que se sente às vezes como uma salsicha, "apanhando dos dois lados" - da comunidade e da equipe - ou que "cão que tem muito dono morre de fome", tem-se a dimensão do risco de um processo solidário e solitário, guiado pelo bom senso e pelos valores conformados por uma vida de igual.

Nessa perspectiva, há necessidade de desenvolvimento e incorporação de tecnologias que apóiem a identidade do Agente Comunitário de Saúde do QUALIS, integrando as diferentes dimensões de sua atuação: as previstas e as necessárias.

Para poder realizar a sua tarefa com maior probabilidade de sucesso e menor sofrimento individual, pela concepção cotidiana das limitações dadas para uma ação isolada, considera-se que seria importante uma maior inserção do agente comunitário em projetos intersetoriais, expressão de política pública global que, assumida pelos diferentes setores de governo e da sociedade, poderia contribuir para o lidar com as questões relativas à saúde, à qualidade de vida e à cidadania da população e do próprio agente comunitário de saúde. 


\section{REFERENCIAS}

\subsection{FONTES DE DADOS DOCUMENTAIS}

[MS] Ministério da Saúde. Fundação Nacional de Saúde - Departamento de Operações. Programa Nacional de Agentes Comunitários de Saúde. Brasília (DF); 1993.

[MS] Ministério da Saúde. Fundação Nacional de Saúde - Departamento de Operações. Programa Nacional de Agentes Comunitários de Saúde. Brasília (DF); 1994.

[MS] Ministério da Saúde. Fundação Nacional de Saúde. Programa Nacional de Agentes Comunitários de Saúde - Manual de Recrutamento e seleção. Brasília (DF); 1991.

[MS] Ministério da Saúde. Fundação Nacional de Saúde. Programa Nacional de Agentes Comunitários de Saúde - Higiene. Brasília (DF); 1993.

[MS] Ministério da Saúde. Fundação Nacional de Saúde. Programa Nacional de Agentes Comunitários de Saúde - Curso de Formação de Agentes Comunitários de Saúde - Roteiro de Atividades para o Coordenador Municipal de Saúde. Brasília (DF); 1991.

[MS] Ministério da Saúde. Fundação Nacional de Saúde; Programa de Agentes Comunitários de Saúde. Manual do Agente Comunitário de Saúde. Brasília (DF); 1991.

[MS] Ministério da Saúde. Fundação Nacional de Saúde; Programa de Agentes Comunitários de Saúde. Avaliação qualitativa do PACS. Brasília (DF); 1994. 
[MS] Ministério da Saúde. Fundação Nacional de Saúde; Programa de Agentes Comunitários de Saúde. O trabalho do Agente Comunitário de Saúde. Brasília (DF); 1994.

[MS] Ministério da Saúde. Fundação Nacional de Saúde; Programa de Agentes Comunitários de Saúde. Ações Básicas e Desenvolvimento da Criança. Brasília (DF); 1994.

[MS] Ministério da Saúde. Fundação Nacional de Saúde; Programa de Saúde da Família. Saúde Dentro de Casa. Brasília (DF); 1994.

[MS]Ministério da Saúde. Programa Comunidade Solidária; Programa de Agentes Comunitários de Saúde. Programa de Agentes Comunitários de Saúde. Brasília (DF); 1997.

[MS]Ministério da Saúde. Secretaria de Assistência à Saúde. Manual para a Organização da Atenção Básica. Brasília (DF); 1999.

[MS]Ministério da Saúde. Secretaria de Políticas de Saúde. Anais da Reunião Técnica dos Pólos de Capacitação, Formação e Educação Permanente em Saúde da Família: 26 a 28 de maio de 1999. Brasília; 2000.

[MS]Ministério da Saúde. Secretaria do Estado da Saúde - Casa de Saúde Santa Marcelina. Projeto qualidade integral em saúde: uma reorientação das ações de saúde em unidades básicas do Núcleo III (Zona Leste). mimeo: 1995.

[MS]Ministério da Saúde. Secretaria do Estado da Saúde - Fundação E.J. Zerbini.

Projeto qualidade integral em saúde: programa saúde da família. mimeo: 1997.

Ministério do Planejamento, Orçamento e Gestão. Instituto de Pesquisa Econômica Aplicada. A vinculação institucional de um trabalhador sui generis - o Agente Comunitário de Saúde. Rio de Janeiro (RJ); 2000. 
[MS] Ministério da Saúde. Coordenação de Atenção Básica. Avaliação da implantação e funcionamento do Programa de Saúde da Família - PSF. Brasília (DF); 2000.

[MS] Ministério da Saúde. Coordenação de Atenção Básica. Seminário de Experiências Internacionais em Saúde da Família - Relatório Final. Brasília (DF); 1999.

[MS] Ministério da Saúde. Coordenação de Saúde da Comunidade. Saúde da família: uma estratégia para a reorientação do modelo assistencial. Brasília (DF); 1997.

[MS] Ministério da Saúde. Coordenação de Saúde da Comunidade. SAÚDE DA FAMÍLIA NO BRASIL - Linhas Estratégicas para o Quadriênio 1999/2002. Brasília (DF); 1999.

[MS] Ministério da Saúde. Coordenação de Saúde da Comunidade; Programa de Agentes Comunitários de Saúde. O Trabalho do Agente Comunitário de Saúde. Brasília (DF); 1995.

[MS] Ministério da Saúde. Fundação Nacional de Saúde - Departamento de Operações. Programa Nacional de Agentes Comunitários de Saúde. Brasília (DF); 1991.

Ministério Público do Trabalho. Procuradoria Geral; Programa Agentes Comunitários de Saúde. Estudo sobre o programa dos Agentes Comunitários de Saúde do Ministério da Saúde. Brasília (DF); 2000.

Secretaria de Estado da Saúde. Prefeitura Municipal de Mauá. Programa de Saúde da Família do Município de Mauá. São Paulo; 1999.

Secretaria do Estado de São Paulo. Projeto QUALIS II - Relatório de Produção. São Paulo; 1998. [mimeo]. 
Secretaria de Estado da Saúde. Programa Saúde da Família. Implantação e desenvolvimento PSF / QUALIS. São Paulo: Governo do Estado de São Paulo; 1999.

\subsection{REFERÊNCIAS BIBLIOGRÁFICAS}

Abbott P, Wallace C. The sociology of the caring professions. London: The Falmer Press; 1990

Amado J, Ferreira MM, organizadores. Usos \& Abusos da história oral. Rio de Janeiro: FGV; 1996.

Andrade FM. O Programa de Saúde da Família no Ceará. Fortaleza: Edição de Arte e Projeto Gráfico; 1998.

Ayres, JR. Epidemiologia e emancipação. São Paulo: Hucitec; 1995.

Ayres J.R. Cuidado: tecnologia ou sabedoria prática. Comentários sobre o artigo “ Um ensaio sobre o médico e suas valises tecnológicas", de Merhy. Interface comunicação, saúde, educação. 2000; 4(6):117-20.

Bastos NCB. SESP/F.SESP 1942 - Evolução Histórica - 1991. $2^{\text {a }}$ ed . Brasília: Fundação Nacional de Saúde;1996.

Bardini 1. -Análise do conteúdo - Presses Universitaires de France. São Paulo: Livraria Martins Fontes; 1977.

Becker HS. Métodos de Pesquisa em Ciências Sociais. São Paulo: Hucitec; 1994.

Bonelli MG. Origem Social, Trajetória de Vida, Influências Intelectuais, Carreira e Contribuições Sociológicas de Elliot Freidson. In: Freidson E. Renascimento do Profissionalismo. São Paulo: Editora da Universidade de São Paulo; 1998.

Breslow, L. Da prevenção das doenças à promoção da saúde. JAMABrasil. 1999;3(7):2252-61. 
Buss, P. M. Promoção da saúde e qualidade de vida. Rio de Janeiro, Ciência \& Saúde Coletiva.2000;5(1):163-77.

Chizzotti A. Pesquisa em Ciências Humanas e Sociais. São Paulo: Cortez; 1991.

Contandriopoulis AP et al. A Avaliação na Área da Saúde: Conceitos e Métodos. In: Hartz ZMA ,organizador. Avaliação em Saúde: dos Modelos Conceituais à Prática na Análise da Implantação de Programas. Rio de Janeiro: FIOCRUZ; 1997.

Contandriopoulis AP et al. A Avaliação na Área da Saúde: Conceitos e Métodos. In: Contandriopoulos AP et al. Saber preparar uma pesquisa: definição, estrutura, financiamento. São Paulo/Rio de Janeiro: Hucitec/Abrasco; 1994.

Contandriopoulos AP et al. Saber preparar uma pesquisa: definição, estrutura, financiamento. SP/RJ: Hucitec/Abrasco; 1994.

Costa Filho DC. O Desafio da Qualidade Integral em Saúde. São Paulo: [mimeo]; 1998.

Cunha JP. Mauá - O amor faz a diferença. Rev Brasileira de Saúde da Família. 1999: 30-9.

Cyrino, APP. Organização tecnológica do trabalho na reforma das práticas e dos serviços de saúde: estudo de um serviço de atenção primária à saúde. São Paulo; 1993. [Dissertação de mestrado - Faculdade de Medicina da USP].

Czeresnia D. The concept of health and the difference between prevention and promotion. Cad. Saúde Pública. 1999;15(4):701-09.

Dalmaso ASW. Estruturação e transformação da prática médica: estudo de algumas características do modelo de trabalho médico na segunda metade do 
século XIX e início do século XX. São Paulo; 1991 [Tese de Doutorado - Faculdade de Medicina da USP].

Denis JL, Champagne F. Análise da Implantação. In: Hartz ZMA ,organizador. Avaliação em Saúde: dos Modelos Conceituais à Prática na Análise da Implantação de Programas. Rio de Janeiro: FIOCRUZ; 1997.

Donnangelo MCF. Medicina e Sociedade. São Paulo: Pioneira; 1975.

Donnangelo MCF, Pereira L. Saúde e Sociedade. São Paulo: Duas Cidades; 1976.

Donnangelo, MCF. Relatório de assessoria prestada à Divisão Nacional de Educação Sanitária sobre metodologia da educação no setor saúde. mimeo: 1976.

Donnangelo MCF. Educação sanitária e políticas de saúde. mimeo:1976.

Donnangelo, MCF. Aspectos da política social brasileira e da participação comunitária em saúde. mimeo: sem data.

Durkheim E. Prefácio da $2^{\mathrm{a}}$ Edição. Da Divisão do Trabalho Social. In: Os Pensadores. v. XXIII. São Paulo: Editora Abril; 1973. p.305-23.

Elias N, Scotson JL. Os Estabelecidos e os Outsiders - sociologia das relações de poder a partir de uma pequena comunidade. Trad. de V Ribeiro.Rio de Janeiro: Jorge Zahar; 2000.

Elias PEM. Das propostas de descentralização da saúde ao SUS: as dimensões técnica e político-institucional. São Paulo; 1996. [Tese de Doutorado - Faculdade de Medicina da USP].

Foucault, M. O nascimento da Clínica. Rio de Janeiro: Forense Universitária; 1977.

Foucault M. O nascimento da Medicina Social. Microfísica do poder. 2 ed, Rio de Janeiro: Graal; 1981. p.79-98. 
Freidson E. Professionalism, caring, and nursing. Paper preoared for The Park Ridge Center. Illinois: Park Ridge; 1990.

Freidson E. Renascimento do Profissionalismo. São Paulo: Editora da Universidade de São Paulo; 1998.

Friedrichs J. Methoden empirischer Sozialforschung. Opladen: Westdeutscher Verlag; 1990.

Galvão S. A expansão dos Agentes de Saúde. Revista do InCor. InCor/HCFMUSP. São Paulo; março 1998.

Gentile M. Promoção da Saúde. Promoção da Saúde, Ministério da Saúde, Secretaria de Políticas de Saúde, ano1, n.1, p. 9-11, ago-out1999.

Girardi SN. A situação atual dos Recursos Humanos em Saúde no Brasil (Sinais do Mercado de Trabalho e Aspectos de sua Regulação nos anos 90). Brasília: Ministério da Saúde - Coordenação Geral de Desenvolvimento de Recursos Humanos para o SUS; 1995.

Guba EG, Lincoln YS. Fourth generation evaluation. Newbury Park: Sage Publications; 1989.

Haguette TMF. Metodologias Qualitativas na Sociologia. Rio de Janeiro: Petrópolis; 1995.

Hartz ZMA ,organizador. Avaliação em Saúde: dos Modelos Conceituais à Prática na Análise da Implantação de Programas. Rio de Janeiro: FIOCRUZ; 1997.

Jatene AD, Novaes HMD, Malik AM, Goldbaum M, Marsiglia RG, Silva JA, Seixas P. Primeiro Relatório Técnico-Científico - Novos modelos de Assistência à Saúde: 
Avaliação do Programa de Saúde da Família no Município de São Paulo. São Paulo: FAPESP; 2000.

Lüdke M, André M. Pesquisa em educação: abordagens qualitativas. $3^{\mathrm{a}}$. ed. São Paulo: EPU; 1988.

MacDonald KM. The sociology of the professions. London: Sage Production Press; 1995.

Machado $\mathrm{MH}$ et al. O mercado de trabalho em saúde no Brasil: estrutura e conjuntura. Rio de Janeiro: ENSP; 1992.

Machado MH. Sociologia das profissões: uma contribuição ao debate teórico. In: Machado MH (org.). Profissões de saúde: uma abordagem sociológica. Rio de Janeiro: FIOCRUZ; 1995.

Malik AM, Schiesari LMC. Qualidade na gestão local de serviços e ações de saúde. São Paulo: IDS/NAMH-FSPUSP/Itaú; 1998.

Marconi MA, Lakatos EM. Técnicas de Pesquisa. São Paulo: Atlas S.A; 1988.

Marsiglia R, Mendes Gonçalves R.B, Carvalho E. A produção do conhecimento e das práticas sociais. Terapia Ocupacional. 1991;.2:114-26.

Marsiglia RMG. SERVIDOR, FUNCIONÁRIO, TRABALHOR: interesses e culturas organizacionais no setor público de saúde. São Paulo; 1993. 2 v. [Tese de Doutorado - Faculdade de Filosofia, Letras e Ciências Humanas da Universidade de São Paulo].

Marx K. El Capital - Critica de la Economia Politica. $4^{\mathrm{a}}$ ed. Mexico: Fondo de Cultura Economica, 1966 
Mays N, Pope C. Qualitative research in health care: Assessing quality in qualitative research. BMJ. 2000; 320: 50-52.

Mendes EV. O processo social de distritalização da saúde. PAIM, J.S. A reorganização das práticas em distritos sanitários. Distrito sanitário: o processo social de mudança das práticas sanitárias do Sistema Único de Saúde (Mendes, org). São Paulo - Rio de Janeiro, HUCITEC-ABRASCO, 1995. p. 93-158.

Mendes-Gonçalves RB. Tecnologia e organização social das práticas de saúde: características tecnológicas do processo de trabalho na rede estadual de Centros de Saúde de São Paulo. São Paulo; 1986. [Tese de Doutorado - Faculdade de Medicina da Universidade de São Paulo].

Mendes-Gonçalves RB. Práticas de Saúde: Processos de trabalho e necessidades.

São Paulo: CEFOR; 1992.

Mendes-Gonçalves RB. Tecnologia e Organização Social das Práticas de Saúde Características Tecnológicas do Processo de Trabalho na Rede Estadual de Centros de Saúde de São Paulo. São Paulo: Editora Hucitec/ABRASCO; 1994.

Merhy EE. Um ensaio sobre o médico e suas valises tecnológicas. Interface comunicação, saúde, educação. 2000; 4: 109-16.

Miles MB, Huberman AM. Qualitative data analysis: an expanded sourcebook. $2^{\mathrm{a}}$. ed. Thousend Oaks: Sage: 1995.

Minayo MC, D’Elia JC, Svitone E. Programa Agentes de Saúde do Ceará. Fortaleza: Fundo das Nações Unidas para a Infância - UNICEF: 1990.

Minayo MCS (org). Pesquisa Social; teoria, método e criatividade. $5^{\mathrm{a}}$ ed. Petrópolis (RJ): Vozes; 1994.

Minayo MCS. O desafio do conhecimento - Pesquisa qualitativa em saúde. São Paulo/Rio de Janeiro: Hucitec; 1992. 
Mishima SM, Silva EM, Anselmi ML, Ferreira SL. Agentes Comunitários de Saúde: Bom para o Ceará...Bom para o Brasil? Saúde em Debate. 1992; 37: 92-95.

Neiburg F. A sociologia das relações de poder de Norbert Elias. In: Elias N, Scotson JL., Os Estabelecidos e os Outsiders - sociologia das relações de poder a partir de uma pequena comunidade. Trad. de V Ribeiro, J Zahar. Rio de Janeiro: Rio de Janeiro; 2000; p.7-11.

Nemes MIB. A hanseníase e as práticas sanitárias em São Paulo: 10 anos de SubPrograma de Controle de Hanseníase na Secretaria de Estado da Saúde (19771987). São Paulo, 1989. [Dissertação de Mestrado - Faculdade de Medicina da USP] Nemes MIB. Prática programática em saúde.In: Schraiber, L. B.; Nemes, MIB.; Mendes-Gonçalves, RB., organizadores Saúde do Adulto: programas e ações na Unidade Básica. São Paulo, HUCITEC, 1996. p.48-65.

Nogueira $\mathrm{R}$ et al. A vinculação institucional de um trabalhador sui generis - o agente comunitário de saúde. [Texto para Discussão 735]. 2000. Disponível em <URL: http://www.ipea.gov.br [2000 Jun 33p.]

Novaes HMD. Avaliação de programas, serviços e tecnologias em saúde. Rev. Saúde Pública. 2000; 34 (5): 547-59. Disponível em <URL http://fsp.usp.br/rsp [2000 Out]

Novaes HMD. Epidemiologia e avaliação em serviços de atenção médica: novas tendências na pesquisa. Cadernos de Saúde Pública. 1996; 12(supl.2):7-12.

Offe C. Trabalho e Sociedade: Problemas estruturais e perspectivas para o futuro da "Sociedade do Trabalho". Trad Gustavo Bayer. Rio de Janeiro: Tempo Brasileiro; 1989.

Paim JS. A reorganização das práticas em distritos sanitários. Distrito sanitário: o processo social de mudança das práticas sanitárias do Sistema Único de Saúde (Mendes, org). São Paulo - Rio de Janeiro, HUCITEC-ABRASCO, 1995. p.187-220. 
Patton MQ. Qualitative Evaluation and Research Methods. Thousend Oaks: Sage; 1990.

Patton MQ. Utilization focused evaluation. Thousand Oaks: SAGE, 1997.

Peduzzi M. Equipe multiprofissional de saúde: a interface entre trabalho e interação. Campinas: Faculdade de Ciências Médicas (UNICAMP); 1998. [Tese de Doutorado - Faculdade de Ciências Médicas da Universidade Estadual de Campinas].

Peduzzi, M. O trabalho multiprofissional em saúde: questões teóricas e conceituais.

[Texto apresentado no I Encontro dos Programas de Aprimoramento Profissional, Fundação do Desenvolvimento Administrativo - Fundap; 1999 setembro 30; São Paulo, Brasil].

Queiroz MIP. Variações sobre a Técnica de gravador no registro de Informação. São Paulo: Viva; 1991.

Quivy R, Van Campenhoudt L. Manual de investigação em Ciências Sociais. 2a . ed. Lisboa: Gradativa Publicações Ltda; 1998.

Robertson A, Minkler, M. New Health promotion movement: a critical examination. Health Education Quarterly,1994: 21(3): 295-312.

Rosen, G. Da Polícia Médica à Medicina Social. Rio de Janeiro: Graal; 1980.

Sartre, JP. Questão de Método. In: Pessanha, JAM. Sartre. Vida e Obra. 3. ed. São Paulo: Nova Cultural; 1987 (Coleção Os Pensadores).

Schraiber LB. O médico e seu trabalho. Limites da liberdade. São Paulo: Hucitec; 1993. 
Schraiber LB. Medicina tecnológica e prática profissional contemporânea: novos desafios, outros dilemas. São Paulo; 1997. [Tese de Livre-Docência - Faculdade de Medicina da USP].

Schraiber L; Nemes MIB, Mendes-Gonçalves RB (orgs). Necessidades de saúde e atenção primária. Saúde do Adulto: programas e ações na Unidade Básica. São Paulo: HUCITEC; 1996. p.29-47.

Silva JA, Mendes Gonçalves RB, Goldbaum M. Atenção Primária de Saúde: avaliação da experiência do Vale do Ribeira. Brasília: Centro de Documentação do Ministério da Saúde. Série Estudos e Projetos: 1986(2), 173p.

Silva JA. Assistência Primária de Saúde: O Agente de Saúde do Vale do Ribeira. São Paulo; 1984. [Dissertação de Mestrado - Faculdade de Saúde Pública da USP].

Souza AI. A Satisfação da População com os Serviços Locais de Saúde Município de Itacarambi (MG). Rio de Janeiro; 1996. [Dissertação de Mestrado ENSP/FIOCRUZ].

Sposatti A. Condições de Saúde e Qualidade de Vida na Cidade. In: Congresso Paulista de Saúde Pública; 1999,out,17-20, Águas de Lindóia. São Paulo: APSP; 2000. p. 23-41.

Thiollent M. Crítica, Metodologia, Investigação Social e Enquete Operária. São Paulo: Polis; 1995.

Vasconcelos EM. A priorização das famílias nas políticas de saúde. Saúde em Debate. Rio de Janeiro. 1999; v. 23: 6-19.

Wilson JQ. Bureaucracy: what government agencies do and why they do it. New York: Basic Books; c1989. 